UNIVERSIDADE DE BRASÍLIA

FACULDADE DE EDUCAÇÃO

PROGRAMA DE PÓS-GRADUAÇÃO EM EDUCAÇÃO

TATIANA SANTOS ARRUDA

A CRIATIVIDADE NO TRABALHO PEDAGÓGICO DO PROFESSOR E O MOVIMENTO EM SUA SUBJETIVIDADE 
TATIANA SANTOS ARRUDA

\section{A CRIATIVIDADE NO TRABALHO PEDAGÓGICO DO PROFESSOR E O MOVIMENTO EM SUA SUBJETIVIDADE}

Tese apresentada ao Programa de Pós- Graduação em Educação da Faculdade de Educação da Universidade de Brasília/UnB como parte dos requisitos para a obtenção do título de Doutor em Educação, na área de Escola, Aprendizagem, Ação Pedagógica, e Subjetividade na Educação.

Orientadora Prof. ${ }^{a}$ Dr. ${ }^{a}$ Albertina Mitjáns Martínez

Brasília, 2014 
TATIANA SANTOS ARRUDA

\title{
A CRIATIVIDADE NO TRABALHO PEDAGÓGICO DO PROFESSOR E O MOVIMENTO EM SUA SUBJETIVIDADE
}

\author{
BANCA EXAMINADORA
}

\author{
Prof. ${ }^{a}$ Dr. ${ }^{\text {a }}$ Albertina Mitjáns Martínez \\ Faculdade de Educação - Universidade de Brasília \\ Orientadora
}

Prof. ${ }^{a}$ Dr. ${ }^{a}$ Ângela Magda Rodrigues Virgolim Instituto de Psicologia - Universidade de Brasília

Examinadora

Prof. ${ }^{a}$ Dr. ${ }^{a}$ Maria Carmen Villela Rosa Tacca

Faculdade de Educação - Universidade de Brasília

Examinadora

Prof. Dr. Maurício da Silva Neubern

Instituto de Psicologia - Universidade de Brasília

Examinador

Prof. Dr. Roberto Valdés Puentes

Faculdade de Educação - Universidade Federal de Uberlândia

Examinador

Prof. ${ }^{a}$ Dr. ${ }^{a}$ Erenice Natália Soares de Carvalho

Universidade Católica de Brasília

Examinadora suplente 


\section{AGRADECIMENTOS}

Agradeço a Deus o dom da vida, sua presença constante e fortalecedora em todos os projetos sonhados e realizados.

Aos meus pais, Sônia e Luiz, pelo apoio incondicional em todos os momentos vividos. O orgulho e alegria que demonstraram, em relação aos meus sonhos acadêmicos, me deram forças para ir à busca de mais conhecimento.

Aos meus irmãos: Deise, Fabiana e André, pessoas especiais que me fazem companhia, me acolhem e me alegram. Não poderia deixar de agradecer, em especial, à Fabiana e ao Rogger por me darem as chaves de sua casa para que eu pudesse estudar dias a fio.

Ao meu esposo, Carlos, que aceita minhas decisões e escolhas acadêmicas. Às minhas filhas queridas e amadas, Maria Júlia e Ana Laura, por me mostrarem, constantemente, que sou privilegiada por tê-las ao meu lado. Com elas, sinto, no dia a dia, que as emoções têm o caráter gerador.

À professora Albertina, pessoa admirável, por sua orientação precisa e constante. Obrigada por favorecer o meu desenvolvimento e avançar na compreensão da criatividade. Realizei o sonho de ser sua orientanda!

Ao professor González Rey por sua produção teórica fascinante!

Aos professores Ângela Virgolim, Carmen Tacca, Maurício Neubern, Roberto Puentes e Erenice Carvalho por participarem da banca e contribuírem para minha aprendizagem. E àqueles professores com quem pude aprender ao longo da minha trajetória acadêmica.

Às amigas que tenho o privilégio da convivência: Theresa, Elisângela, Gislaine, Valdívia e Lu Oliveira por serem confidentes de tantas alegrias, dúvidas, afetos e desafetos. Em especial, agradeço a Joana, irmã-amiga, por seu apoio e por, também, ter cedido as chaves de sua casa para que eu pudesse estudar e construir este trabalho.

Aos colegas de formação: Ana Luiza, que tanto nos ensinou no início deste estudo, Francisca, Lu Campolina, Gláucia, Carol, Mônica, Victor, Talyta, pelas trocas e pela oportunidade de aprendermos juntos. De modo especial, agradeço a Lu Muniz, mais que colega de formação, uma amiga, que tanto me apoiou e auxiliou nos momentos finais deste estudo!

Ao Fábio pela preciosa correção e pelo résumé, feitos com tanto empenho. À Pilar por sua disponibilidade em auxiliar com o abstract.

Aos professores que participaram desta pesquisa, particularmente, a Ananda, Júlia e Laura por me permitirem aprender a ser pesquisadora e, antes, uma professora. Muito obrigada!

À Secretaria de Educação do DF pelo afastamento concedido e pela experiência de ser educadora da rede pública de ensino. 


\section{RESUMO}

Esta pesquisa possui como tema a criatividade no trabalho pedagógico do professor e os movimentos na subjetividade dos docentes, a partir das produções subjetivas que se formam no curso dessa expressão criativa. Tivemos como objetivo geral: compreender processos subjetivos que configuram a criatividade no trabalho pedagógico do professor e suas interrelações com o movimento em sua subjetividade. Assumimos, neste estudo, a definição de criatividade como processo complexo da subjetividade humana, na simultânea condição de subjetividade individual e subjetividade social, a qual se expressa no trabalho pedagógico por meio de novidades com valor para o processo de aprendizagem e desenvolvimento dos estudantes, conforme a abordagem teórica de Mitjáns Martínez. E a subjetividade que se define segundo a perspectiva Histórico-Cultural desenvolvida por González Rey. Para a investigação empreendida, pautamo-nos na Epistemologia Qualitativa e na realização de três estudos de casos com professores da rede pública de ensino do Distrito Federal. Para a construção das informações, utilizamos como instrumentos: observação; análise documental; entrevistas; túnel do tempo; redações; completamento de frases; resolução de situações do cotidiano educativo; conversas informais; dentre outros. O processo construtivo-interpretativo nos permitiu formular a tese de que os processos subjetivos que configuram a criatividade no trabalho pedagógico do professor são singulares, históricos e atuais e se relacionam de forma recursiva aos próprios processos de movimento em sua subjetividade. Dentre os processos subjetivos que configuram essa criatividade, encontram-se: a subjetivação do papel do professor, vinculado à responsabilidade frente ao trabalho pedagógico; a subjetivação do aluno como ativo e participativo no processo de aprendizagem; a subjetivação da aprendizagem escolar relacionada à compreensão e a elaboração pessoal a partir do aprendido; a subjetivação da função social da educação concebida como a formação integral dos estudantes; a subjetivação de conhecimentos de áreas específicas, que se expressam no trabalho pedagógico realizado. Além desses processos, a construção das informações do estudo de casos nos permitiu compreender a participação, na criatividade do trabalho pedagógico do professor: da imaginação; da intencionalidade pedagógica, da autoria e protagonismo do professor como expressão de sua condição de sujeito; de núcleos subjetivos específicos de sua subjetividade individual; e, do funcionamento psicológico criativo, expressão da dimensão funcional da criatividade. Por último, uma importante construção desta pesquisa, foi a consideração do aluno como um outro social que participa da criatividade no trabalho pedagógico do professor, por meio de necessidades pedagógicas e desafios educativos que implicam o docente para a produção de novidades com valor para o seu processo de aprendizagem e desenvolvimento.

Palavras-chave: Criatividade do professor. Trabalho pedagógico. Subjetividade. Movimentos subjetivos. 


\begin{abstract}
The main theme of this research relates to teachers' creativity in pedagogical work and the movements in the subjectivity of teachers derived from subjective productions that form in the course of this creative expression. Its general objective is to understand subjective processes that configure the teacher's creativity in pedagogical work and their interrelations with the movement in the teacher's subjectivity. In accordance with Mitjáns Martínez's theoretical approach, we assume, in this study, the definition of creativity as a complex process of human subjectivity, in its simultaneous condition of individual subjectivity and social subjectivity, which is expressed in the pedagogical work through innovations of value to the process of learning and development of students. We assume, as well, the conception of subjectivity from a Historical-Cultural perspective as developed by González Rey. As for the research methodology, we undertook the Qualitative Epistemology approach through the analysis of three case studies with teachers in public schools of the Federal District. For the construction of information, we used instruments such as: observation; document analysis; interviews; time warp; essays; completing phrases; resolution of the education everyday situations; and informal conversations. The constructive-interpretive process allowed us to formulate the hypothesis that the subjective processes that shape the creativity in the teacher's pedagogical work are singular, historic and actual; and they recursively relate to movement processes of the teacher's subjectivity. Among the subjective processes that shape this creativity are: the subjectivation of the teacher's role associated to the responsibility towards the pedagogical work; the subjectivation of the learner as an active and participative instance in the learning process; the subjectivation of school learning as the understanding and the personalization of what is learnt; the subjectivation of the social function of education, conceived as the integral formation of the students; the subjectivation of knowledge in specific areas that are expressed through the intended pedagogical work. In addition to these subjective processes, the construction of information in the case studies allowed us to understand the participation of the following aspects in the teacher's creativity in pedagogical work: the imagination; the pedagogical intentionality, the authourship and the protagonism of the teacher as an expression of his/her subject condition; specific subjective cores of his individual subjectivity; and the creative psychological functioning, an expression of the functional dimension of creativity. Finally, one of our significant research constructions was the understanding of the student as a social other who participates in the teacher's creativity in pedagogical work through his/her educational needs and educational challenges that require the teacher to produce novelty with value for his/her learning and development processes.
\end{abstract}

Key word: Teacher's creativity. Pedagogical work. Subjectivity. Subjective movements. 


\section{RÉSUMÉ}

Cette recherche a pour thème la créativité dans le travail pédagogique des enseignants et les mouvements de la subjectivité des enseignants, depuis des productions subjectives qui se forment pendant cette expression créative. L'objectif général est comprendre processus subjectifs qui configurent la créativité dans le travail pédagogique d' enseignant et de leurs interrelations avec le mouvement dans sa subjectivité. Dans cette étude, on supposée la définition de la créativité comme un processus complexe de la subjectivité humaine, dans la condition simultanée de la subjectivité individuelle et de la subjectivité sociale, qui s'exprime dans le travail pédagogique au moyen des innovations avec la valeur au processus d'apprentissage et de développement des élèves, selon l'approche théorique de Mitjáns Martínez. Et la subjectivité qui se définie en fonction de la perspective Historique et Culturelle développée par González Rey. Dans le recherche menée, on a guidé pour l'Épistémologie Qualitative et pour la réalisation des études de cas avec trois enseignants des écoles publiques du District Fédéral (Brésil). Pour obtenir les informations, on a utilisé les instruments suivants: l'observation; l'analyse de documents; les interviews; tunnel de temps; les essais; le compléter des phrases; le résolution des situations quotidiennes d'éducation; conversations informelles; et autres. Le processus de construction et interprétation a permis formuler l'hypothèse que les processus subjectifs qui façonnent la créativité dans le travail pédagogique des enseignants sont uniques, historiques et actuelles et se rapportent de manière récursive aux prope processus de mouvement dans leur subjectivité. Parmi les processus subjectifs qui façonnent cette créativité, on trouve: la subjectivation du rôle de l'enseignant, liée à la responsabilité pour le travail pédagogique; la subjectivation d'éleve comme un actif et participatif dans le processus d'apprentissage; la subjectivation de l'apprentissage scolaire lié à la compréhension et le développement personnel depuis l'appris; la subjectivation de la fonction sociale de l'éducation conçue comme la formation intégrale des étudiants; la subjectivation des connaissances dans des domaines spécifiques, qui sont exprimés dans le travail pédagogique. En plus de ces processus, la construction de l'information d'étude de cas nous a permis de comprendre la participation dans la créativité du travail pédagogique de l'enseignant: l'imagination; l'intentionnalité pédagogique, l'écrit et le rôle de l'enseignant comme une expression de sa condition de sujet; le noyau subjective spécifique de sa subjectivité individuelle; et le fonctionnement psychologique de création, qui est l'expression de la dimension fonctionnelle de la créativité. Enfin, un important construction de cette recherche, c'était la consideration de l'élève comme un autre sociale qui participant de la créativité dans le travail pédagogique d'enseignants, par l'intermédiaire de demandes éducatifs et de défis de l'éducation qui impliquent des enseignants à produire des nouvelles avec valeur pour le processus d'apprentissage et le développement.

Mots clés: Céativité du enseignant. Travail pédagogique. La subjectivité. Mouvements subjectifs. 


\section{LISTA DE QUADROS}

Quadro 1 - Número de materiais identificados na revisão de

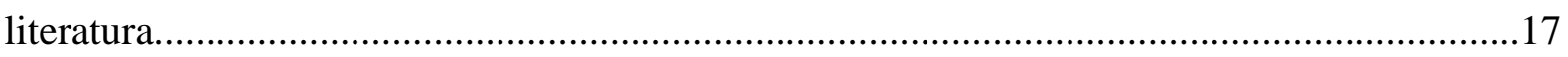

Quadro 2 - Lista com os autores que se dedicaram ao estudo do professor criativo e do ensino criativo, segundo maior ênfase .23

Quadro 3 - Relação entre as concepções predominantes identificadas nos estudos e os autores que as identificaram

Quadro 4 - Barreiras à expressão criativa dos professores segundo o que os autores encontraram em seus resultados

Quadro 5 - Barreiras à expressão criativa dos estudantes segundo o que os autores encontraram em seus resultados

Quadro 6 - Identifica os autores que tratam de temáticas relacionadas ao papel do professor para estímulo à criatividade

Quadro 7 - Características do professor facilitador da criatividade dos estudantes e os autores que as identificaram

Quadro 8 - Procedimentos, métodos e estratégias que estimulam a criatividade dos estudantes e os autores que as identificaram. .46

Quadro 9 - Os instrumentos da pesquisa com a professora Ananda.... .99

Quadro 10 - Os instrumentos da pesquisa com a professora Júlia 141

Quadro 11 - Os instrumentos da pesquisa com a professora Laura. 186 


\section{SUMÁRIO}

INTRODUÇÃO.

1 A PRODUÇÃo CIENTÍFICA A RESPEITO DA CRIATIVIDADE NO TRABALHO PEDAGÓGICO DO PROFESSOR.

1.1 Os estudos realizados acerca da criatividade do professor ..........................................18

1.1.1 Trabalhos que visam compreender o campo da criatividade .........................................19

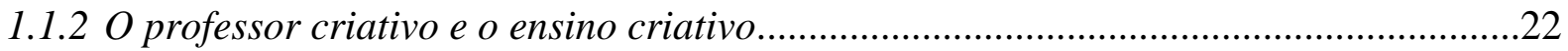

1.1.3 As concepções de criatividade dos professores.............................................................27

1.1.4 Os fatores inibidores ou facilitadores da criatividade do professor...............................36

1.1.5 O papel do professor para o desenvolvimento da criatividade do estudante..................43

1.2 Os estudos realizados acerca da criatividade no trabalho pedagógico..........................50

2 A TEORIA DA SUBJETIVIDADE NA PERSPECTIVA HISTÓRICO-CULTURAL

E A CRIATIVIDADE NO TRABALHO PEDAGÓGICO DO PROFESSOR.............53

2.1 Aproximações à Teoria da Subjetividade na perspectiva Histórico-Cultural................53

2.1.1 Movimento, impacto, mudanças e desenvolvimento da subjetividade ............................58

2.2 A criatividade no trabalho pedagógico: os significados para o professor e para a prática educativa.

2.2.1 A criatividade como processo complexo da subjetividade humana.

2.2.2 A criatividade no trabalho pedagógico: a produção de novidades com valor para a aprendizagem e desenvolvimento dos alunos.

3 EPISTEMOLOGIA QUALITATIVA DE GONZÁLEZ REY E METODOLOGIA DE INVESTIGAÇÃO.

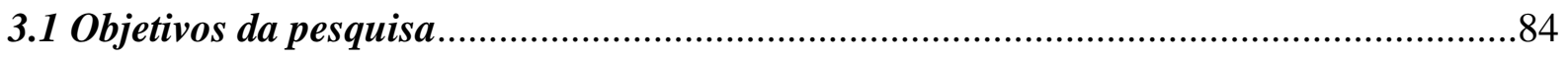

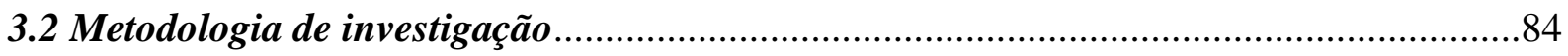

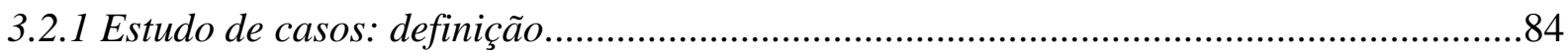

3.2.2 Os participantes e procedimentos da pesquisa ..............................................................86

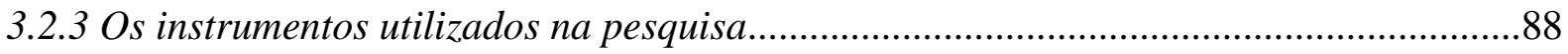

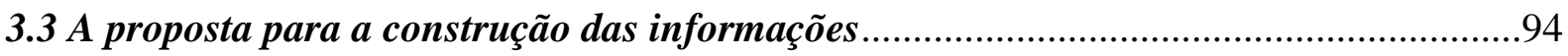




\section{PROCESSO CONSTRUTIVO-INTERPRETATIVO REALIZADO NA PESQUISA -}

ESTUDO DE CASOS

4.1 O caso da professora Ananda.

4.1.1 Quem é a professora Ananda? Onde atua? Informações iniciais

4.1.2 Contexto da instituição educativa onde Ananda atuava .................................................98

4.1.3 Os instrumentos da pesquisa com a professora Ananda

4.1.4 Expressões criativas no trabalho pedagógico: a professora Ananda como sujeito de sua prática profissional.

4.1.5 A subjetividade individual da professora Ananda: sua condição de sujeito e os núcleos subjetivos que participavam de sua criatividade no trabalho pedagógico......

4.1.5.1 Os principais núcleos subjetivos da professora Ananda que participavam de sua criatividade no trabalho pedagógico.

4.1.5.2 Os processos de movimento na subjetividade individual da professora Ananda...... 133

4.1.6 Considerações parciais acerca do caso da professora Ananda.

4.2 O caso da professora Júlia

4.2.1 Quem é a professora Júlia? Onde atua? Informações iniciais....

4.2.2 Contexto da instituição educativa onde Júlia atuava

4.2.3 Os instrumentos da pesquisa com a professora Júlia.

4.2.4 Expressões criativas no trabalho pedagógico: a professora Júlia como sujeito de sua prática profissional.

4.2.5 A subjetividade individual da professora Júlia: sua condição de sujeito e os núcleos subjetivos que participavam de sua criatividade no trabalho pedagógico

4.2.5.1 Os principais núcleos subjetivos da professora Júlia que participavam de sua criatividade no trabalho pedagógico.

4.2.5.2 Os processos de movimento na subjetividade individual da professora Júlia. 175

4.2.6 Considerações parciais acerca do caso da professora Júlia. 182

4.3 O caso da professora Laura. 184

4.3.1 Quem é a professora Laura? Onde atua? Informações iniciais. 
4.3.4 Expressões criativas no trabalho pedagógico: a professora Laura como sujeito de sua prática profissional.

4.3.5 A subjetividade individual da professora Laura: sua condição de sujeito e os núcleos subjetivos que participavam de sua criatividade no trabalho pedagógico

4.3.5.1 Os principais núcleos subjetivos da professora Laura que participavam de sua criatividade no trabalho pedagógico.

4.3.5.2 Os processos de movimento na subjetividade individual da professora Laura.....

4.3.6 Considerações parciais acerca do caso da professora Laura.

5 ANÁliSE INTEGRATIVA dOS CASOS, PRODUÇÃO TEÓRICA ACERCA DA CRIATIVIDADE NO TRABALHO PEDAGÓGICO DO PROFESSOR E O

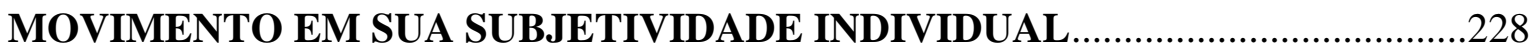

CONSIDERAÇÕES FINAIS

REFERÊNCIAS

APÊNDICE A - ROTEIRO PARA OBSERVAÇÕES NO COTIDIANO EDUCATIVO...... 260

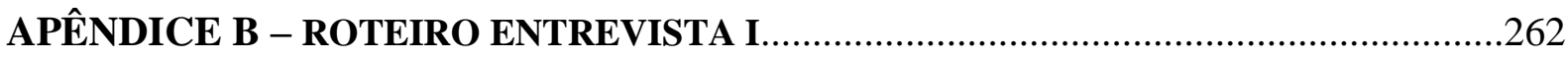

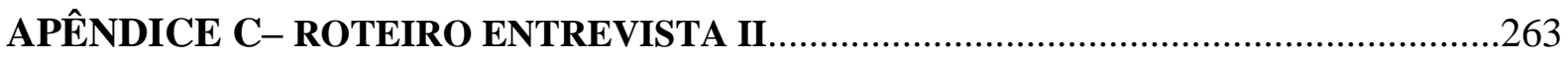

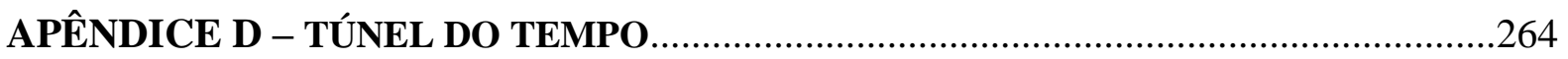

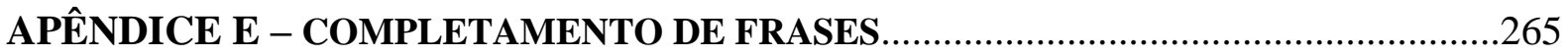

APÊNDICE F - RESOLUÇÃO DE SITUAÇÕES DO COTIDIANO EDUCATIVO.............267

APÊNDICE G - DUAS GRANDES PREMIAÇÕES....................................................269 


\section{INTRODUÇÃO}

Na sociedade contemporânea observamos, cada vez mais, a necessidade de que o contexto escolar favoreça a formação humana, o desenvolvimento integral dos estudantes, bem como a produção e utilização de conhecimentos em diferentes situações cotidianas, a solução de situações-problema e o posicionamento frente aos desafios que surgem. Hoje, fazse relevante um processo educativo que favoreça a formação de indivíduos críticos, participativos, reflexivos e criativos. Ampliam-se, com isso, as exigências para a ação docente e as diferentes dimensões que precisam perpassar a organização do trabalho pedagógico.

Para alcançar finalidades tão amplas como essas, torna-se imprescindível considerar a diversidade social, cultural e histórica que caracteriza os estudantes em seus processos constitutivos. Diversidade essa que marca sua aprendizagem e desenvolvimento, solicitando ao professor cuidados para a elaboração de objetivos, conteúdos e estratégias pedagógicas que atendam às diferentes formas de aprender e as diversas áreas de interesse que os alunos possuem.

Nesse contexto, evidencia-se o papel e a importância da criatividade no trabalho pedagógico do professor, a qual favorece a formulação de práticas e ações educativas que podem promover a utilização e mobilização de diferentes recursos favoráveis à aprendizagem e formação dos alunos, atendendo, assim, a diversidade dos estudantes e as demandas sociais para a educação.

A criatividade no trabalho pedagógico do professor é, então, uma urgência quando se tem em vista os princípios de democratização do ensino, a diversidade presente na dinâmica escolar e a própria finalidade do trabalho pedagógico: ensinar e educar (MITJÁNS MARTÍNEZ, 2008a). Para Mitjáns Martínez (2008a, p. 73) “[...] a complexidade, diversidade e singularidade dos processos de aprendizagem e desenvolvimento humanos demandam ações diversificadas e criativas se a pretensão é realmente promovê-los de forma efetiva."

Assim, pautadas no entendimento da importância dos processos criativos no trabalho pedagógico, empreendemos a revisão da literatura nacional e internacional, tendo por finalidade uma aproximação aos estudos que tivessem como objeto de investigação os professores e sua expressão criativa no trabalho pedagógico. Nesse processo, compreendemos que podem existir diferenças sutis entre os termos criatividade do professor e criatividade no trabalho pedagógico. Diferenças que se relacionam, em especial, à possibilidade de a criatividade no trabalho pedagógico enfatizar a expressão criativa presente nos diferentes 
momentos da prática educativa, os indivíduos situados em contextos reais, as relações históricas e atuais de professores, estudantes, famílias e comunidade.

Entendemos que as pesquisas, nessa direção, envolvem diversos aspectos que integram a criatividade no trabalho pedagógico do professor, como a forma de organização dos conteúdos a serem explorados, a elaboração e seleção de estratégias de ensino, o processo de planejamento e construção das atividades educativas a serem realizadas e os processos comunicativos entre o docente, os alunos e demais integrantes da comunidade escolar.

Por outro lado, o termo criatividade do professor pode vincular-se a ideia da criatividade como uma característica, um atributo, que se revela no fazer pedagógico e, quiçá, em outros âmbitos da vida do docente. Os estudos nessa vertente procuram, em geral, elementos e aspectos associados ao professor e não, necessariamente, a criatividade em sua prática profissional, nas ações educativas desenvolvidas no cotidiano escolar. Têm como foco processos isolados que podem participar dessa expressão criativa, caracterizando certa fragmentação das pesquisas e produções teóricas.

Os estudos nessa vertente priorizam em suas temáticas: a) compreensão do campo de estudos acerca da criatividade; b) identificação do professor criativo e do ensino criativo; c) identificação das concepções de criatividade dos professores; d) fatores inibidores ou facilitadores da sua expressão criativa; e) papel do docente para o desenvolvimento da criatividade dos estudantes. Esses itens representam tendências de estudo que identificamos na revisão de literatura realizada, que envolveu artigos científicos, dissertações, teses, livros e capítulos de livros no período de 2000 a 2014.

Consideramos que essas temáticas acerca da criatividade do professor são relevantes, mas não permitem avanços significativos para a compreensão sistêmica e integrativa dos processos que constituem a criatividade no trabalho pedagógico, o seu desenvolvimento e expressão no espaço educativo. Em nossa pesquisa, buscamos contribuir para o estudo acerca da expressão criativa do professor em suas práticas pedagógicas, aproximando-nos de diferentes processos subjetivos que configuram essa criatividade, articulando-os no curso da pesquisa a partir da perspectiva da Teoria da Subjetividade de González Rey, no que nos diferenciamos das tendências mais amplas dos estudos dessa área.

Além disso, voltamo-nos para o contexto de ação docente, para as relações entre professor e alunos, para um estudo da expressão criativa do professor que envolva sua história de vida, os cursos formativos dos quais participou e as experiências profissionais anteriores e atuais. Por isso, em nosso estudo, optamos por utilizar o termo criatividade no trabalho 
pedagógico, por acreditar que ela indica, com maior clareza, o que investigamos, a criatividade do professor no curso de sua prática docente. Nessa direção, Mitjáns Martínez (2008a) afirma, esse termo permite, com maior precisão, focar os processos criativos no trabalho do professor, que, por meio da produção de novidades, podem adquirir valor para a aprendizagem e desenvolvimento dos estudantes.

Essa possibilidade de produção do docente no trabalho pedagógico nos chamou a atenção quando investigamos a expressão da criatividade do professor no desenvolvimento do currículo da educação infantil (ARRUDA, 2007). Desse estudo de mestrado e de experiências profissionais posteriores ${ }^{1}$, surgiram as questões iniciais que se vinculavam tanto aos processos subjetivos que configuram essa criatividade no trabalho pedagógico, como à possibilidade do trabalho pedagógico criativo gerar outras movimentações subjetivas no docente. Aspectos esses que, inicialmente, associamos às singularidades da produção de sentidos subjetivos no curso da atuação profissional dos professores considerados como criativos.

Nesta pesquisa de doutorado, o interesse residiu, assim, na ampliação dos conhecimentos relacionados aos processos subjetivos que configuram a criatividade no trabalho pedagógico do professor e suas inter-relações com o movimento na subjetividade do docente. Tais movimentos são diversos, podem se constituir como impactos, movimentações, mudanças ou desenvolvimento subjetivo. Essas inter-relações entre criatividade e movimentos subjetivos podem ser compreensíveis à luz do que entendemos por criatividade: um processo complexo da subjetividade humana na simultânea condição de subjetividade individual e subjetividade social, e que, se revela no trabalho pedagógico por meio da produção de novidades com valor para os processos de aprendizagem e desenvolvimento dos alunos, conforme defende Mitjáns Martínez (2004, 2008a).

Esse processo subjetivo é fundamentado na Teoria da Subjetividade na Perspectiva Histórico - Cultural, de González Rey. Para o autor (2011b, p. 30), a subjetividade é definida “[...] não apenas como organização intrapsíquica individual, mas como produção diferenciada e simultânea de sentidos subjetivos em dois níveis estreitamente relacionados entre si: o individual e o social.”. Trata-se, portanto, de uma produção simbólica em unidade inseparável com as emoções, e que se caracteriza, ao mesmo tempo, como histórica e atual, em constante possibilidade de movimento e de mudanças qualitativamente distintas.

\footnotetext{
${ }^{1}$ Sou professora de educação infantil e anos iniciais do ensino fundamental na Secretaria de Estado de Educação do Distrito Federal.
} 
Considerar essa perspectiva da criatividade e de mobilidade subjetiva nos permite compreender que a expressão criativa no trabalho pedagógico não se revela por meio de ações pontuais e isoladas; ao contrário, é sistêmica (MITJÁNS MARTÍNEZ, 2003a 2008a, 2008b). Requer o envolvimento do professor, sua implicação e compromisso com o trabalho pedagógico, clareza quanto às demandas sociais em relação à educação, aos objetivos de aprendizagem e às propostas curriculares, definindo-se como um processo que rompe, em muitas situações, com práticas pedagógicas que se perpetuam nos espaços educativos e são aceitas socialmente como ações legítimas para o favorecimento dos processos de aprendizagem dos alunos.

A criatividade, então, não se restringe ao diferente, à produção de novidades ou às produções artísticas, é mais que inserção de recursos e de atividades diversificadas pontuais. Para Mitjáns Martínez (2003a, 2008a, 2008b), abrange diferentes dimensões da prática pedagógica que se articulam mutuamente, como a seleção e formulação de objetivos de aprendizagem, a organização das estratégias, dos métodos de ensino e do processo docente, dos sistemas de avaliação e das oportunidades de autoavaliação, dentre outros aspectos destacados no que denomina como Sistema Didático Integral.

Essas dimensões da prática pedagógica constituem o trabalho pedagógico, o qual consideramos, ainda, como o conjunto de crenças, pressupostos teóricos, concepções (acerca da educação, aluno, ensino, dentre outras), de práticas e ações educativas planejadas e realizadas pelos docentes com a finalidade de favorecer a aprendizagem e desenvolvimento dos estudantes, o que ocorre em um trabalho conjunto com os próprios alunos e outros profissionais da educação. A intenção deste estudo centrou-se, especificamente, no trabalho pedagógico do professor.

Nessas ações, consideramos que a criatividade no trabalho pedagógico do professor poderá trazer benefícios para os estudantes e os seus processos de aprendizagem, no que nos aproximamos da dimensão instrumental da criatividade. Consideramos, ainda, o valor da criatividade para o próprio professor e para os processos de movimento subjetivo do docente, para o seu funcionamento psicológico, na perspectiva da dimensão funcional da criatividade, como define Mitjáns Martínez (2009a).

Nessa direção, compreendemos que a criatividade no trabalho pedagógico pode ser valiosa para o professor, isto é, as situações geradas pela produção de novidades com valor para a aprendizagem dos estudantes podem gerar produções subjetivas que favoreçam a condição de sujeito do professor, o desenvolvimento de outros recursos subjetivos e processos 
de reorganização subjetiva, possibilitando, como afirma Mitjáns Martinez (2002, 2008a), a realização pessoal e profissional, o bem estar emocional e a saúde do docente.

Essa possibilidade de estudo da expressão criativa docente, também diferencia nossa pesquisa de outras linhas de investigação no campo da criatividade do professor, pois tem em vista o valor dessa expressão criativa para o próprio docente, aspecto que contribui, ainda, para a compreensão das relações entre as experiências históricas e atuais dos professores no que se refere à criatividade e as produções subjetivas que se constituem com base nessa criatividade, favorecendo movimentos subjetivos no professor.

No processo de pesquisa, partimos, assim, da seguinte questão de pesquisa: quais são os processos subjetivos que configuram a criatividade no trabalho pedagógico do professor e quais são suas inter-relações com o movimento em sua subjetividade? O que se traduz no objetivo geral deste estudo: compreender processos subjetivos que configuram a criatividade no trabalho pedagógico do professor e suas inter-relações com o movimento em sua subjetividade.

Os objetivos específicos foram:

a) analisar expressões de criatividade no trabalho pedagógico do professor;

b) analisar a subjetividade individual do professor que expressa criatividade no trabalho pedagógico, com foco na condição de sujeito e nos principais núcleos subjetivos que participam dessa criatividade;

c) analisar o movimento na subjetividade individual do professor que desenvolve um trabalho pedagógico criativo.

Com base nesses objetivos, foi possível avançarmos na articulação e especificidades dos processos subjetivos que participam da expressão criativa do professor no trabalho pedagógico, em especial, o que se refere à sua condição de sujeito e à subjetividade individual. Fundamentadas nas construções dos três estudos de caso, formulamos a tese: os processos subjetivos que configuram a criatividade no trabalho pedagógico do professor são singulares, históricos e atuais e se relacionam de forma recursiva aos próprios processos de movimentos em sua subjetividade. Dentre os processos subjetivos que configuram essa criatividade, encontram-se:

a) a subjetivação do papel do professor, vinculada à responsabilidade frente ao trabalho pedagógico;

b) a subjetivação do aluno, como ativo e participativo no processo de aprendizagem; 
c) a subjetivação da aprendizagem escolar relacionada à compreensão e a elaboração pessoal a partir do aprendido;

d) a subjetivação da função social da educação direcionada à formação integral dos estudantes, o que abrange o contato com diferentes áreas do conhecimento, articulandose, ainda, à intencionalidade pedagógica que permeia as práticas educativas;

e) a subjetivação de conhecimentos de áreas específicas.

A pesquisa nos possibilitou compreender, ainda, o aluno como um outro social que participa da criatividade no trabalho pedagógico do professor, por meio de necessidades pedagógicas e desafios educativos que implicam o docente para a produção de novidades com valor para o seu processo de aprendizagem e desenvolvimento. Também nos permitiu entender a participação da imaginação no trabalho pedagógico criativo; da intencionalidade pedagógica, da autoria e protagonismo do professor no trabalho pedagógico como expressão de sua condição de sujeito; de núcleos subjetivos específicos de sua subjetividade individual, que se atualizam no curso das experiências pedagógicas criativas; e do funcionamento psicológico criativo, a dimensão funcional da criatividade.

Para orientar o leitor a respeito das construções realizadas, apresentamos, inicialmente, a revisão da literatura com as principais tendências de estudo identificadas nas produções e estudos que versam acerca da expressão criativa do professor no trabalho pedagógico, que compõe o capítulo 1. Em seguida, delineamos a fundamentação teórica, capítulo 2, que contempla a Teoria da Subjetividade na perspectiva Histórico-Cultural de González Rey, o movimento, impactos, mudanças e possibilidade de desenvolvimento subjetivo. E, indicamos a definição de criatividade adotada no estudo, como processo complexo da subjetividade humana que se relaciona, no trabalho pedagógico, à produção de novidades com valor para a aprendizagem e desenvolvimento dos estudantes.

No terceiro capítulo, apontamos a base epistemológica e metodológica dessa pesquisa, segundo a Epistemologia Qualitativa, a forma como entendemos e realizamos o estudo de casos. O quarto capítulo envolve as construções sobre os casos de Ananda, Júlia e Laura. E no capítulo 5, apresentamos a análise integrativa dos casos. Finalizamos este trabalho com as considerações finais do estudo. 


\section{A PRODUÇÃO CIENTÍFICA A RESPEITO DA CRIATIVIDADE NO TRABALHO PEDAGÓGICO DO PROFESSOR}

Com a finalidade de compreender a produção científica vinculada à expressão criativa no trabalho pedagógico, empreendemos uma revisão de literatura nacional e internacional. Essa revisão envolveu a análise de artigos, dissertações, teses, livros e capítulos de livros que contemplavam como objeto de estudo o professor e sua criatividade no exercício de sua atuação profissional. O quadro 1 sintetiza o número de materiais encontrados, segundo a classificação utilizada.

Quadro 1 - Número de materiais identificados na revisão de literatura

\begin{tabular}{|c|c|c|c|c|c|}
\hline \multicolumn{6}{|c|}{ Materiais identificados } \\
\hline \multirow[b]{3}{*}{ Total } & Artigos científicos & Dissertações & Teses & Capítulos de Livros & Livro \\
\hline & 52 & 46 & $\begin{array}{l}9 \\
\end{array}$ & 13 & 0 \\
\hline & \multicolumn{5}{|c|}{120} \\
\hline
\end{tabular}

Fonte: a autora (2014).

Para a seleção desses materiais, consideramos o período do ano de 2000 a 2014 e utilizamos os descritores: criatividade do professor, criatividade no ensino, criatividade no trabalho pedagógico, criatividade e escola e outras combinações entre eles. As buscas envolveram a base de dados da Coordenação de Aperfeiçoamento de Pessoal de Nível Superior - CAPES (artigos nacionais e internacionais); Scientific Electronic Library Online SciELO; Periódicos Eletrônicos em Psicologia - PePSIC; ProQuest (teses e dissertações internacionais); Biblioteca Digital Brasileira de Teses e Dissertações - BDTD e Google Acadêmico.

Os trabalhos identificados conduziram à distinção inicial entre os estudos voltados para a criatividade do professor, daqueles que tinham como foco a criatividade no trabalho pedagógico, tema de estudo desta pesquisa. Assim, apresentaremos, primeiramente, as tendências de estudos relacionadas à expressão da criatividade do professor. Abordaremos depois, em um tópico específico, as produções que se direcionam a criatividade no trabalho pedagógico. Destacamos que não serão discutidas questões teórico-metodológicas desses estudos, mas sim as temáticas centrais que se apresentam, o que nos possibilita entender o que tem sido investigado no campo da criatividade do professor em sua prática docente.

Ressaltamos também que, nesse capítulo, reconhecemos a importância da apresentação e breve descrição dos estudos identificados, permitindo diferenciar a nossa pesquisa na área 
relacionada à criatividade do professor e evidenciar os possíveis avanços das construções decorrentes deste trabalho. Prosseguimos, com isso, para a compreensão dos estudos realizados acerca da criatividade do professor e daqueles relacionados à criatividade no trabalho pedagógico.

\subsection{Os estudos realizados acerca da criatividade do professor}

Os trabalhos identificados a respeito da criatividade do professor mostram-se em maior número, contemplando cerca de $93 \%$ dos materiais selecionados. Na análise, foram priorizadas as principais temáticas e os resultados alcançados nas pesquisas, de modo que foram explorados diferentes aspectos de um mesmo estudo. Após esse momento, empreendemos o diálogo com o campo, pautadas na literatura nacional e internacional, e, apresentamos o nosso posicionamento frente aos resultados.

Nesse processo, foi possível identificar que na área de criatividade do professor predominam cinco tendências de estudo, as quais foram formuladas depois da seleção dos trabalhos que se relacionavam a criatividade no trabalho pedagógico do professor. Tais tendências foram denominadas como:

a) trabalhos que visam compreender o campo da criatividade e os estudos desenvolvidos sob determinadas categorias observadas e especificadas pelos autores;

b) o professor criativo e o ensino criativo: indicam as características e os elementos que podem identificar um professor criativo e o que seria um ensino criativo;

c) concepções de criatividade dos professores: identificam as principais concepções de criatividade dos docentes, relacionando-as com a prática pedagógica e a possibilidade de mudanças em decorrência de processos de formação;

d) fatores inibidores ou facilitadores da criatividade do professor: buscam identificar os aspectos que interferem na expressão criativa, ou como alguns estudos chamam, as barreiras à criatividade. Esses aspectos se dividem, ainda, entre os que procuram tais fatores do ponto de vista do professor, influenciando sua criatividade, e aqueles que focam tais fatores para o desenvolvimento criativo dos estudantes, segundo os professores;

e) papel do professor para o desenvolvimento da criatividade dos estudantes: relacionados à tendência anterior, esses trabalhos privilegiam a figura do professor em função do desenvolvimento da expressão criativa dos estudantes. Discorrem acerca de suas características e dos procedimentos que podem ser utilizados com tal finalidade. 
Algumas dessas tendências apresentadas são discutidas de forma conjunta. Lembramos que essas categorias foram elaboradas, tendo em vista a necessidade de compreender os principais temas pesquisados, e com isso, apontar os estudos realizados na área de criatividade do professor.

\subsubsection{Trabalhos que visam compreender o campo da criatividade}

Os trabalhos que visam compreender o campo da criatividade, por sua especificidade, viabilizam o mapeamento da produção internacional e nacional a respeito de determinadas temáticas. No período selecionado (2000 a 2014), foram identificados dez artigos e um capítulo de livro, publicado no Brasil, que tratavam do tema. Desses, referiam-se de modo específico à criatividade do professor, os trabalhos de: Talita Silva et al. (2012), Arruda e Martínez (2012), Reilly et al. (2011) e Nakano (2009).

Tais estudos permitem a compreensão de diferentes assuntos pesquisados no campo da criatividade, proporcionando a identificação das temáticas em foco, dos participantes que compõem os trabalhos investigativos, os tipos de pesquisas realizadas, dentre outros aspectos. Ademais, permitem a visualização da figura do professor em diferentes âmbitos investigados, ainda que o centro da pesquisa não fosse a criatividade do professor.

Nessa perspectiva, foi possível analisar que a expressão criativa no contexto escolar, em especial do professor, tem sido objeto de estudo em diversas direções, como aponta Arruda e Martínez (2012). No Brasil, as autoras identificaram, no período de 2000 a 2012, quatro principais temáticas: a) os estudos cienciométricos a respeito da criatividade; b) as concepções de criatividade dos professores; c) os fatores inibidores ou facilitadores da expressão criativa do professor; d) o papel do professor para o estímulo à criatividade dos alunos.

Em período anterior, década de 1990, Wechsler (2001) procurou identificar, em dissertações e teses que tratavam da criatividade, quais eram o público pesquisado na cultura brasileira e os principais temas investigados. Para tanto, partiu do consenso atual de que a criatividade é um processo multidimensional, que envolve a pessoa, o processo, o produto e o ambiente, e que tais dimensões estão em contínua interação. Por meio de suas combinações, possibilitam a realização profissional e pessoal.

Em seu trabalho, a autora afirmou a predominância de duas grandes linhas de pesquisa, a primeira delas diz respeito à criatividade no ensino, em que se inserem as pesquisas que 
privilegiam os efeitos de programas específicos de criatividade na sala de aula e aqueles que observam as estratégias de ensino usadas para conduzir à criatividade dos estudantes. $\mathrm{Na}$ segunda, estão os estudos com foco na criatividade no trabalho, os quais priorizam a identificação do perfil de um indivíduo inovador, de líderes criativos que não necessariamente atuam no espaço escolar.

Em um período próximo ao estudo de Wechsler (2001), Zanella e Titon (2005) investigaram o tema da criatividade nos materiais produzidos nos programas de pósgraduação em Psicologia no Brasil, considerando as publicações de 1994 a 2001. As pesquisadoras verificaram em seu estudo: o número de dissertações ou teses produzidas sobre o assunto; o tipo do estudo; a temática principal; a linguagem artística e o referencial teórico. Em suas conclusões, evidenciaram que a principal temática pesquisada foi a criatividade na prática pedagógica, com $39,7 \%$ dos estudos.

De forma semelhante, Nakano e Wechsler (2007) concluíram que há grande interesse dos pesquisadores brasileiros pelo tema da criatividade, principalmente na área educacional. Investigaram dissertações, teses e as publicações periódicas realizadas nos anos de 1984 a 2006 que tratavam acerca do assunto. As autoras identificaram a predominância de estudos qualitativos e de cunho educacional $(31,8 \%)$, sendo realizados $48,1 \%$ com adultos. Além disso, afirmaram que os professores compunham a amostra de $40 \%$ das publicações periódicas e 33,3\% das teses e dissertações.

A pesquisa de Talita Silva e Nakano (2012) envolveu pesquisadores da pós-graduação na área de Psicologia e reafirmou o interesse, nos últimos quinze anos (1995-2009), acerca da criatividade de professores que atuam no ensino fundamental e seus alunos. Nessa direção, encontra-se, também, o estudo de Talita Silva et al. (2012), o qual possibilita compreender como foi investigado o professor e sua expressão criativa. Para as autoras, o tema que mais se destacou nos 42 materiais selecionados, por elas, foi a criatividade nas práticas pedagógicas do docente.

De modo mais específico, a pesquisa realizada por Nakano (2009, p. 45) buscou “[...] identificar as pesquisas brasileiras sobre criatividade realizadas com amostras de professores a fim de verificar o que tem sido estudado e os resultados que vêm sendo obtidos.”. Esse estudo se aproxima do objetivo proposto para esta revisão, no entanto, se diferencia basicamente pelas bases de dados utilizadas e pelos descritores usados para as buscas. A pesquisadora investigou apenas a base Scielo, com a palavra-chave criatividade. 
Nos resultados alcançados por ela, estavam as temáticas: a) influência da organização escolar sobre a criatividade e contribuições dos professores nesse processo; b) concepções dos professores sobre a criatividade; c) capacidade de esses docentes identificarem a criatividade em seus alunos; d) dificuldades e limitações na criação de ambiente criativo; e) treinamentos de modelos de atuação criativa. Nesse aspecto, diferencia-se em parte das temáticas identificadas como predominantes nos estudos identificados em nossa pesquisa. Isso porque outros temas mostram-se mais relevantes nos últimos anos, tendo em vista os descritores utilizados e apresentados anteriormente.

Com a palavra-chave "criatividade", Bachert et al. (2011) apresentaram os resultados encontrados em bases de dados nacionais e internacionais, contemplando o período de 2000 a março de 2011. A pesquisa empreendida pelas autoras (BACHERT et al., 2011, p. 348) tinha como objetivo a análise de "[...] artigos empíricos que investigaram a criatividade como caminho para a inovação e melhoria das práticas pedagógicas nas diferentes fases de ensino, desde a educação infantil até a pós-graduação."

A análise apresentada por elas indicou que a criatividade foi mais estudada a partir do ano de 2005 e que tem sido associada ao desempenho escolar, tanto de estudantes com dificuldades de aprendizagem como daqueles com altas habilidades. Indicaram, também, que os estudos com foco na formação de professores têm ressaltado a importância da criatividade como uma habilidade a ser desenvolvida e exercitada, sendo considerada como um fator que pode colaborar para o enfrentamento dos problemas presentes nas relações professor-aluno e no desenvolvimento de outras estratégias de ensino.

A pesquisa desenvolvida por Wechsler e Nakano (2011) aproxima-se de tais afirmativas voltadas para a formação. Para as autoras a formação docente é fundamental para favorecer aulas mais criativas; além disso, investigar questões relacionadas à temática pode gerar informações relevantes sobre o clima em sala de aula, ou seja, a "[...] ambiência para o pensamento e comportamentos criativos.” (WECHSLER; NAKANO, 2011, p. 20).

Nesse estudo, as referidas autoras tinham como finalidade fazer um levantamento das pesquisas em criatividade e educação em trabalhos acadêmicos (dissertações e teses) e publicações científicas, sem delimitar ano de publicação. Em seus resultados, identificaram, ainda, cinco temas predominantes: a) concepção de criatividade: visão de professores e alunos; b) perfil do professor criativo; c) características de alunos criativos; d) formação de professores e estratégias de ensino; e) programas para o desenvolvimento da criatividade. 
Os resultados apontados por Wechsler e Nakano (2011), em conjunto com os demais trabalhos que visam compreender o campo de criatividade, indicam que há interesse pela criatividade no contexto escolar, bem como pela figura do professor nas pesquisas sobre criatividade. Isso fica evidente quando Nakano e Wechsler (2007) afirmam que quase metade das amostras das pesquisas investigadas era composta por professores e que a criatividade na prática pedagógica tem se apresentado como um tema presente em grande parte dos estudos, tal como afirmou Zanella e Titon (2005).

No entanto, apenas quatro desses estudos (NAKANO, 2009; SILVA, T. et al., 2012; ARRUDA; MARTÍNEZ, 2012; REILLY et al, 2012) buscaram investigar a criatividade do professor e as tendências de estudos nessa área. Isso indica que, a despeito do reconhecimento da relevância da criatividade no ambiente escolar, ainda há lacunas na produção de pesquisas sobre a criatividade no curso do trabalho pedagógico, em especial, carência de estudos que possibilitem a investigação dos materiais produzidos, artigos, teses, dissertações a respeito da expressão criativa nos diferentes aspectos da prática educativa.

Por outro lado, observamos o interesse de pesquisadores nacionais e internacionais acerca das características que definem um professor criativo e como é um ensino criativo, o que diz respeito a outra tendência de estudo identificada nesta revisão de literatura.

\subsubsection{O professor criativo e o ensino criativo}

Segundo diferentes autores (MITJÁNS MARTÍNEZ, 2003a; DE LA TORRE, 2005; VIRGOLIM, 2007), os estudos na área de criatividade podem enfatizar quatro dimensões básicas: a pessoa que expressa criatividade, o processo criativo, o contexto, meio ou ambiente que possibilita a criatividade, e o produto da expressão criativa. Os trabalhos que se aproximam do professor criativo estão mais centrados na pessoa e nos aspectos que evidenciam sua criatividade no âmbito da docência. No entanto, não deixam de considerar um suposto produto, considerado como o ensino criativo e as relações sociais, o meio educativo. Por isso, nesta seção, abordaremos os estudos que, no período investigado, abarcam tanto o professor criativo como o ensino criativo, temas extremamente associados nos materiais identificados, mas que em alguns trabalhos foram tratados separadamente.

A respeito do professor criativo e do ensino criativo, encontramos um total de vinte e um trabalhos. No quadro 2 apresentamos os autores que abordaram tais temáticas, segundo maior ênfase. 
Quadro 2 - Lista com os autores que se dedicaram ao estudo do professor criativo e do ensino criativo, segundo maior ênfase $^{2}$

\begin{tabular}{||l|l||}
\hline \multicolumn{1}{|c|}{$\begin{array}{c}\text { Priorizaram o estudo sobre o } \\
\text { professor criativo }\end{array}$} & \multicolumn{1}{c|}{$\begin{array}{c}\text { Priorizaram o estudo sobre o } \\
\text { ensino criativo }\end{array}$} \\
\hline \hline - Oliveira; Alencar (2012) & - Aquino (2012) \\
- Padget (2012) & - Chang et al.(2011) \\
- Zélia Oliveira (2012) & - Aschenbrener at al. (2010) \\
- Rinkevich (2011) & - Casangiu (2010) \\
- Morais; Azevedo (2011) & - Jeffrey (2006) \\
- Reilly et al. (2011) & - De La Torre (2005) \\
- Khan (2008) & - Horng et al. (2005) \\
- Chennabathni (2006) & - Hansen (2005) \\
- Lilly (2002) & - Jeffrey; Craft (2004) \\
- Oliveira; Wechsler (2002) & - Garde (2003) \\
& - Garde; Andrade (2003) \\
\hline
\end{tabular}

Fonte: a autora (2014).

Antes de discutirmos essas temáticas, esclarecemos que segundo a nossa perspectiva, o ensino criativo e trabalho pedagógico criativo não são sinônimos. Consideramos que o ensino criativo pressupõe um significado mais restrito, voltando-se para as relações professor-aluno e para as atividades realizadas com vistas aos processos de apropriação dos conhecimentos científicos. O trabalho pedagógico criativo contempla, além do ensino, a expressão da criatividade na dinâmica mais ampla dos processos educativos, abrange os diferentes participantes do contexto escolar, as relações entre eles, as ações e atividades que visam aos processos de aprendizagem e desenvolvimento dos estudantes, como o planejamento e a formação docente. Mais à frente, iremos fundamentar como compreendemos o trabalho pedagógico, o que poderá elucidar as diferenças apresentadas neste momento.

Dentre os trabalhos dedicados ao docente criativo, encontra-se o estudo realizado por Lilly (2002), que investigou o retrato qualitativo de um professor criativo e o seu processo de ensino. Sua investigação ocorreu no ensino superior, em uma universidade canadense, com uma professora com mais de vinte anos de experiência em diferentes níveis de ensino. As informações de sua pesquisa afirmam que o professor criativo prepara de forma intensa e minuciosa o seu processo de ensino, envolve-se nas relações com os estudantes, faz e proporciona conexões entre os assuntos trabalhados e, além disso, viabiliza um ensino reflexivo.

Os resultados alcançados por Chennabathni (2006) estão próximos às afirmações de Lilly (2002). No estudo desenvolvido pela pesquisadora, também em contexto canadense, as

\footnotetext{
${ }^{2}$ Ressaltamos que nem todos os trabalhos que foram identificados neste quadro serão abordados nesse tópico, o que decorre das especificidades que os autores apresentam e das divergências com o foco que pretendemos dar ao texto.
} 
relações interpessoais que envolviam a professora de seu estudo de caso, com os estudantes e a comunidade em que ela residia, foram valiosas para a constituição de um ensino criativo. Também os valores e o modo de vida da docente, orientaram sua prática e decisões de ensino.

No contexto europeu, encontra-se a pesquisa de Morais e Azevedo (2011), que tinham o intuito de investigar as percepções dos professores portugueses a respeito do que é um professor criativo e um ensino criativo. Encontraram em sua pesquisa atributos em relação aos docentes vinculados: ao entusiasmo pelas aulas; à promoção da autonomia dos estudantes; à segurança e competência científica; as relações de amizades entre professores e estudantes; à prática de exercícios e exemplos e inexistência de rotinas. São aspectos que, segundo as autoras, estão presentes em outras pesquisas semelhantes e em outras abordagens teóricas. Concluíram, entretanto, que se fazem necessários maiores investimentos na formação de professores sobre a criatividade, tendo em vista os indícios de que há pouca familiaridade com o tema e grande indecisão dos docentes frente às questões do estudo.

Para além dos diferentes atributos, De La Torre (2006) enfatiza que um professor criativo deixa marca em seus estudantes, ele motiva, anima, implica os seus estudantes com responsabilidade e liberdade. Para o autor, a melhor síntese a respeito da avaliação de um professor criativo abrange três pilares: a crença em si mesmo, a transmissão aos outros dessa crença em suas próprias qualidades e a transmissão sempre dessa imagem positiva do que se espera dos estudantes. Afirma, ainda, que uma das características desse professor é a relação com os companheiros da instituição de ensino e de sua comunidade. Essas relações envolvem um espírito de colaboração e trabalho em equipe, trocas de conhecimentos e experiências, boas relações, consciência social e de serviço, dentre outros elementos.

Há outras características indicadas para o professor criativo, como: senso de humor, persistência, autoconfiança (HORNG et al., 2005), ousadia, entusiasmo, flexibilidade (OLIVEIRA, Z., 2012) e outros aspectos, como discutido por Rinkevich (2011) em seu ensaio sobre o tema. Essa diversidade de características também se mostrou presente no estudo de Reilly et al. (2011), quando buscaram sintetizar as pesquisas realizadas sobre o professor criativo no contexto canadense.

Nessa investigação, encontraram doze estudos que abordavam o ensino criativo. Desses, dez apontavam características do professor criativo. As principais categorias citadas para essa caracterização foram: inteligência pessoal e motivação. Concluíram que no campo da educação há pouco a respeito da prática criativa de professores. No Brasil, Elzira Oliveira e Wechsler (2002) destacam: a área mais citada acerca das variáveis que afetam o processo de 
ensino e aprendizagem é a criatividade no ensino, sendo o adjetivo "pessoa criativa" o mais mencionado para a qualidade do professor ideal.

Voltado de forma mais específica para a expressão do professor criativo na prática pedagógica, Padget (2012) afirma que os docentes estão sendo mais criativos quando assumem riscos, experimentam e utilizam abordagens pedagógicas que envolvem tanto a si mesmos quanto aos estudantes, permitem que eles visualizem diversas possibilidades e favorecem situações inusitadas e emocionantes oportunidades de aprendizagem. Faz-se relevante, ainda, que sejam flexíveis, façam questionamentos e forneçam suporte para o esforço e as reflexões dos estudantes.

Torrance (1962) já expôs algumas características comuns ao que considerava como docentes criativos, como: flexibilidade, engenhosidade, disposição para "sair da trilha batida" (expressão do autor), sensibilidade. As pesquisas brasileiras aproximam-se dessas características. Nos resultados de Garde (2003), Garde e Andrade (2003), os autores concluíram que para os participantes de seu estudo, a criatividade no ensino foi considerada como um processo de reflexão e sensibilidade, em que o professor tornou-se capaz de identificar as necessidades dos estudantes e buscou, no dia a dia, subsídios importantes para trabalhar o conteúdo de suas disciplinas.

Tais aspectos assemelham-se ao que Hansen (2005) afirma ser características de um ensino criativo: a capacidade de resposta do professor à situação e ao cenário educacional vivido e atenção permanente. Por isso, o autor afirma que abrange toda a estrutura da aula e sua organização, o fluxo das dinâmicas selecionadas, os exemplos oferecidos e as ilustrações utilizadas. A criatividade no ensino, para ele, está associada às experiências docentes e aos conhecimentos advindos dessas experiências, aspectos esses que avançamos em nossa pesquisa.

No âmbito do ensino superior, Aquino (2012) teve como objetivo de sua pesquisa investigar a percepção de professores e estudantes do curso de Pedagogia no que diz respeito às características de um ensino inovador, que foi considerado por ela como um ensino que promove a criatividade. A propósito encontrou como características de um ensino inovador elementos relacionadas a: estar aberto a novas ideias; conectar informações a situações reais; problemas e questões atuais; e apresentar motivação para buscar novos conhecimentos.

Alguns dos aspectos apontados pelos professores da pesquisa de Aquino (2012) foram abordados por De La Torre (2005) quando o autor discutiu as características de um ensino criativo. Para ele, esse ensino apresenta uma natureza flexível e adaptativa, com o predomínio 
de metodologias indiretas, nas quais os estudantes são parte ativa na construção do próprio conhecimento e podem contar com orientação para o desenvolvimento da capacidade e habilidades cognitivas. Também é imaginativo e motivante, estimula a combinação de materiais e ideias, tem um cuidado com os processos de ensino sem descuidar dos resultados, as aprendizagens e, por fim, favorece a relação entre docente e estudantes.

Observamos, nessa perspectiva, que nos estudos de Lilly (2002), Chennabathni (2006), Morais e Azevedo (2011) e De La Torre $(2005,2006)$ as relações entre o professor criativo e os seus estudantes são apresentadas como um dos aspectos constitutivos da criatividade docente. Do nosso ponto de vista, as afirmações dos autores supracitados indicam o papel do outro social para a expressão criativa, o que envolve a relevância das relações sociais no espaço escolar como um dos meios que mobilizam a expressão criativa no curso da prática educativa. Em nosso estudo investigamos de que forma as relações sociais entre docentes e alunos participam dessa criatividade, avançando para além da afirmativa de que são importantes.

Partimos da compreensão de que tais relações entre docentes e demais integrantes da dinâmica educativa podem perpassar e constituir o trabalho pedagógico e a expressão criativa no contexto escolar, de modo que essa criatividade não se configura como atributo de um profissional caracterizado apenas como "professor criativo".

Isso não significa que ignoramos as relações entre a criatividade e as configurações que compõem a personalidade dos professores que expressam criatividade em sua prática. As pesquisas desenvolvidas tanto por Chennabathni (2006) como por Lilly (2002) demonstraram que as características personológicas dos professores considerados como criativos direcionavam o seu ensino, tornando-os criativos segundo as abordagens teóricas que fundamentaram os respectivos estudos. Para Lilly (2002) o processo de ensino criativo foi dirigido pela personalidade da professora observada, influenciando suas escolhas quanto aos materiais utilizados, os métodos para desenvolvimento do currículo da instituição educativa e em sua opção por um ensino reflexivo.

Os estudos de Chennabathni (2006), assim como os de Lilly (2002) com professores criativos, reafirmam a existência de uma diversidade de traços personológicos que podem participar da expressão criativa no trabalho pedagógico. De modo que concordamos com Mitjáns Martínez (2003a, 2008c), segundo a qual não existe um perfil protótipo de personalidade criativa, não há um somatório de traços ou qualidade associados à criatividade. 
Esta não é uma qualidade geral da personalidade expressa em todos os campos de ação do profissional.

Essa relação entre personalidade e atuação criativa apontada pelas pesquisadoras constituiu-se como foco de diferentes estudos (ALENCAR, 2001; LILLY, 2002; CHENNABATHNI, 2006; MITJÁNS MARTÍNEZ, 2003a, 2008c). Mitjáns Martínez (2008c) afirma que outros estudos que possuem essa relação foram tratados em duas direções principais: a) associando a criatividade a um conjunto de traços ou características de personalidade que a pessoa criativa possui, b) concebendo a criatividade como uma forma de autorrealização ou epifenômeno da integridade da personalidade.

Fundamentando-se em trabalhos realizados anteriormente, Alencar (2001) reconhece que não há uma configuração clara que indique traços únicos de personalidade presentes em pessoas criativas. Ainda assim, a autora apresenta alguns traços, como: autonomia, flexibilidade pessoal e abertura à experiência, autoconfiança, iniciativa e persistência, espontaneidade e sensibilidade, dentre outros.

No âmbito do trabalho pedagógico, temos em vista que as relações históricas e atuais dos profissionais, o contexto da instituição, com seus valores, as demandas externas (como exames e avaliações institucionais) e a forma como professor vivencia as adversidades e as experiências docentes podem repercutir na constituição do professor e em sua personalidade e, consequentemente, proporcionar mudanças no seu processo de ensino.

Em nossa pesquisa consideramos tanto o papel da personalidade, conceito que será abordado de forma mais profunda em seção posterior, como das relações sociais para a mobilização de recursos e modificações de processos subjetivos dos professores e dos estudantes. Isso porque, do nosso ponto de vista, a criatividade se constitui por meio de uma complexa trama de aspectos culturais, históricos e atuais, individuais e sociais que perpassam a expressão criativa no trabalho pedagógico. Dentre tais aspectos estão as crenças e as concepções docentes, tema que será enfatizado a seguir no que se refere à criatividade.

\subsubsection{As concepções de criatividade dos professores}

A identificação das concepções de criatividade dos professores se mostrou como um tema privilegiado, compondo trinta trabalhos nacionais e internacionais selecionados neste estudo. Nesses materiais foi possível verificar aproximações e diferenças entre os resultados 
das pesquisas e o que os autores trouxeram acerca das relações entre as concepções apresentadas pelos docentes e sua prática pedagógica.

No artigo de Andiliou e Murphy (2010), por exemplo, as concepções de criatividade foram objeto específico de investigação. Os autores buscaram, nas produções publicadas nos Estados Unidos - Educational Resources Information Center (ERIC), analisar e examinar os resultados de estudos que verificaram as crenças dos professores sobre a criatividade e, também, explorar os conceitos de pesquisadores e professores a respeito do tema. Nesse trabalho, encontraram diferentes concepções, as quais envolviam a natureza da criatividade, como uma construção, o perfil de indivíduos criativos e o ambiente de sala de aula.

Nos resultados, os autores supracitados identificaram um "desalinhamento" entre as concepções de criatividade de professores e pesquisadores; a relação entre as crenças dos professores e a prática de sala de aula; a associação entre crenças sobre criatividade e outros conceitos (escolaridade, a valorização social e inteligência); e o impacto do contexto cultural. Por outro lado, o estudo de Monteiro et al. (2013), em Portugal, trouxe que as variáveis gênero, idade, área curricular e ciclos de ensino dos professores influem na representação de criatividade.

De forma geral, verificamos, nos resultados expostos pelas pesquisas identificadas nesta revisão de literatura, três concepções de criatividade predominantes entre os professores, dentre outras citadas: a) concepções vinculadas ao senso comum, de acordo com os autores; b) concepções inatistas, que julgam a criatividade como uma característica individual com a qual a pessoa nasce, cabendo à instituição educativa deixá-la desenvolver; c) concepções que relacionam a criatividade à transformação e inovação. $\mathrm{O}$ quadro 3 sintetiza as concepções predominantes com os autores que as identificaram.

Quadro 3 - Relação entre as concepções predominantes identificadas nos estudos e os autores que as identificaram

\begin{tabular}{|c|c|c|c|}
\hline \multicolumn{4}{|c|}{ Concepções predominantes identificadas } \\
\hline & Senso comum & Capacidade inata & Capacidade de transformar \\
\hline $\begin{array}{c}\text { Autores que } \\
\text { identificaram essas } \\
\text { concepções }\end{array}$ & $\begin{array}{l}\text { - Nakano (2011) } \\
\text { - Eny Oliveira (2007) } \\
\text { - Eny Oliveira; Alencar } \\
\text { (2010) }\end{array}$ & $\begin{array}{l}\text { - Neves-Pereira (2004) } \\
\text { - Fresquet (2000) } \\
\text { - Libório (2009) } \\
\text { - Libório; Neves (2010) } \\
\text { - Lima (2010) } \\
\text { - Fábio Santos (2013) }\end{array}$ & $\begin{array}{l}\text { - Lucilena Oliveira (2006) } \\
\text { - Eny Oliveira; Alencar (2010) } \\
\text { - Libório (2009) } \\
\text { - Edileusa Oliveira (2009) } \\
\text { - Cardoso; Leite (2009) } \\
\text { - Costa Júnior (2008) } \\
\text { - Libório; Neves (2010) } \\
\text { - Nakano (2011) } \\
\text { - Chiodi et al. (2011) } \\
\text { - Zélia Oliveira (2012) } \\
\text { - Luciana Santos (2013) }\end{array}$ \\
\hline
\end{tabular}

Fonte: a autora (2014). 
Dentre o grupo de trabalho que afirma em seus achados que a criatividade, segundo os professores, relaciona-se ao senso comum, estão as pesquisas de Nakano (2011), Eny Oliveira (2007) e Eny Oliveira e Alencar (2010). Essas últimas autoras tinham como foco a investigação das concepções de criatividade atribuídas por gestores e orientadores educacionais, a importância dada por esses profissionais à expressão criativa e a identificação dos fatores inibidores e facilitadores da criatividade que eles identificavam, no sentido de promovê-la na organização escolar.

$\mathrm{Na}$ análise empreendida, as autoras chegaram à conclusão de que os gestores e orientadores educacionais julgavam a criatividade relevante, entretanto, o conhecimento que tinham a respeito do tema e que embasava sua prática advinha do senso comum. Isso porque as concepções apresentadas por eles estavam relacionadas aos seguintes elementos: à compreensão da criatividade como produtora de novidades ou diferente; como geradora de soluções; como um atributo pessoal; como um elemento de prazer; ou associada às artes.

Concepções semelhantes estiveram presentes também nos resultados alcançados na pesquisa de Nakano (2011). A pesquisadora tinha por finalidade investigar como os professores definem a criatividade, se avaliam-se como criativos na vida pessoal e se utilizam a criatividade na sala de aula. A autora encontrou que a maior parte dos professores avaliou-se como criativo na vida pessoal e profissional (80\%), afirmando que usam a criatividade em sua prática profissional por meio de várias estratégias criativas. Contudo, para esses profissionais, a criatividade está relacionada à ideia de inovação e capacidade de criar algo novo, o que segundo a pesquisadora, converge para a visão do senso comum acerca da criatividade e demonstra desconhecimento sobre o construto.

Tal desconhecimento foi apontado por professores e estudantes da pós-graduação stricto sensu (OLIVEIRA, Z., 2012), que afirmaram ter pouco ou nenhum conhecimento a respeito da criatividade. Ainda assim, para Zélia Oliveira (2012), as concepções apresentadas em sua investigação se relacionam àquelas que coexistem entre os especialistas da área, abrangem: inovação, produtos inovadores, vencer limites e fronteiras, quebra de padrões e solução de problemas.

Essas colocações de Zélia Oliveira (2012) se contrapõem às colocações de Barreto e Martínez (2008). Com professores desse nível de ensino, as autoras encontraram concepções mais intuitivas que científicas, o que pode ser associado às concepções do senso comum. Além disso, identificaram que havia pouca clareza por parte dos docentes, os quais 
vinculavam a expressão criativa à solução de problemas e a restringiam a atividades lúdicas, que poderiam envolver ou não as diferentes tecnologias de informação.

A relação entre o uso de tecnologias e a expressão criativa foi identificada no estudo de Bolden et al. (2010), que investigaram a concepção de criatividade de professores de matemática durante o período de formação no Reino Unido. A análise das informações indicou que tais estudantes tinham, no início de sua formação, concepções restritas, que associavam a criatividade ao uso de recursos e tecnologias da informação. Essas concepções se tornaram, segundo os autores, menos estreitas ao final de sua formação. Foi destacado, também, nesse estudo, que era preciso abordar de forma mais precisa o conceito ao longo do período de formação.

No Brasil, temos ainda os estudos de Lucilena Oliveira (2006), que investigou as concepções de criatividade na educação infantil, e Domingues (2008), que realizou seu estudo com professores dos anos finais do ensino fundamental. De modo geral, as pesquisadoras identificaram que, para os docentes, a criatividade está relacionada à curiosidade, ousadia, solução de problemas, elementos externos e à inovação.

O estudo desenvolvido por Hong e Kang (2010) verificou as concepções de criatividade de professores de ciências que atuavam na Coréia do Sul e nos Estados Unidos, considerando as possíveis influências culturais e contextuais nos conceitos apresentados. Os resultados da pesquisa realizada apontaram que a concepção de cada professor individualmente foi considerada limitada, associando-a predominantemente à novidade e resolução de problemas. Resultado que se assemelha as conclusões de Newton e Beverton (2012), em pesquisa realizada na Inglaterra. Por outro lado, para Hong e Kang (2011), as concepções dos professores de criatividade de maneira geral, em grupo, foram consistentes com informações presentes na literatura do campo.

Essa perspectiva relaciona-se com os achados de Garde (2003) e Garde e Andrade (2003), também no Brasil. Os autores afirmaram que as representações sociais de professores de ensino médio estão associadas a diferentes referenciais teóricos, como o psicanalítico, rogeriano e cognitivista. A análise de suas representações indicou associações entre a criatividade e a espontaneidade, transformação de algo, recriação, e a um novo sentido. Além disso, houve alusões aos conceitos de espontaneidade, conservas culturais e criatividade, de modo integrado e dinâmico, o que para eles mostrou-se pertinente.

Próximo ao que destacaram esses autores, está a pesquisa de Luciana Santos (2013), que afirmou: as concepções dos professores de arte dos anos finais do ensino fundamental sobre 
criatividade estão pautadas em estudos teóricos sobre o tema, envolvem a ideia de que o ato criativo está relacionado aos atributos pessoais que conduzem a produção de produto novo e que sofre julgamento de um meio. O estudo de doutorado de Schirmer (2001) na educação infantil também está nessa direção. Em seus resultados, a autora afirmou que as professoras pesquisadas reconhecem o conceito de criatividade e têm atuações compatíveis com o cenário atual. Dentre suas afirmações estão que as docentes entendem a criatividade com noções desde o senso comum a construções teóricas. Para elas, a criatividade pode se configurar como capacidade inata, capacidade adquirida e/ou pensamento intuitivo (mágico), que surge de forma repentina e deve ser aproveitada na dinâmica educativa.

As construções que consideram a criatividade como uma capacidade inata estiveram presentes em outros resultados alcançados com professores que atuavam em diferentes etapas de ensino, como na educação infantil, no estudo de Neves-Pereira (2004) e Fresquet (2000); no ensino fundamental, pesquisa de Libório (2009) e Libório e Neves (2010); no ensino médio, Fábio Santos (2013); e na pós-graduação stricto sensu, no trabalho de Lima (2010).

Na primeira etapa da educação básica está a pesquisa desenvolvida por Neves-Pereira (2004) que buscou investigar, em nível microgenético, as práticas de professores de educação infantil e sua relação com a promoção ou inibição da criatividade das crianças. Para isso, analisou as concepções de criatividade das professoras, considerando as práticas pedagógicas com vistas à promoção do potencial criativo. Em suas construções, a pesquisadora observou que as concepções das professoras a respeito da criatividade se refletiram em suas práticas, determinando o que acontecia em sala de aula.

Fresquet (2000) também pesquisou na educação infantil e investigou os processos de co-construção do conceito de criatividade no contexto de um minicurso para professores da primeira etapa da educação básica. Em sua pesquisa, a autora analisou a mudança no conceito de criatividade e seu impacto transformador na maneira de cada professor se perceber e se relacionar com o mundo. Dentre os diferentes aspectos presentes em seus resultados, ela demonstrou que, ao longo da construção coletiva do conceito, alguns mitos presentes inicialmente, como: a criatividade é uma qualidade reservada a alguns privilegiados e que todos trazem ao nascer, foram "derrubados". O conceito de criatividade passou a ser relacionado à cultura e compreendido como um processo progressivo de criação do novo, e, segundo a autora, passou a se refletir nas experiências profissionais dos professores envolvidos no minicurso. 
Os achados de Libório (2009) no contexto do ensino fundamental se contrapõem, em parte, ao que Neves-Pereira (2004) e Fresquet (2000) encontraram. Para a primeira pesquisadora, as concepções que os professores apresentam têm poucos efeitos sobre como eles procedem em sua prática profissional. A autora investigou, junto a oito turmas de $5^{\mathrm{a}}$ série do ensino fundamental (matriz curricular de oito anos), as concepções que os professores possuem acerca da relação professor-aluno, criatividade e clima favorável à criatividade e buscou compreender de que maneira essas relações podem favorecer ou não a criatividade em sala de aula.

No que se refere às concepções de criatividade, Libório (2009) identificou que, dos oito professores de sua pesquisa, cinco afirmaram que a criatividade se refere a uma capacidade inata de solucionar problemas de forma inovadora. Outros dois participantes disseram que a criatividade é uma expressão espontânea de uma realidade interna e que se trata de uma capacidade de transformar. No entanto, ressaltou a pesquisadora, o preparo do professor e o seu envolvimento indicam ter mais significado que suas concepções sobre os "fenômenos".

Para além do preparo, Fábio Santos (2013) concluiu, em seu estudo de doutorado, que as crenças sobre criatividade dos professores do ensino médio, participantes de sua pesquisa, tinham o enfoque tradicional ou clássico. Isto é, compreendiam a criatividade como algo inato ao ser humano e que se desenvolve de forma independe dos fatores sociais e culturais.

Nessa direção, encontra-se o estudo de Lima (2010), que envolveu professores de cursos de pós-graduação stricto sensu em Educação de duas universidades públicas de Fortaleza, Ceará. Os resultados mostraram que, para os participantes do estudo, a criatividade é importante por ser uma condição natural do ser humano, indispensável para tornar-se pleno e é, especialmente, associada a atributos do próprio individuo, notadamente o conhecimento. Diz respeito, ainda, a um convite à humanização, à sensibilidade, por promover a inter-relação entre as pessoas e desenvolver a autonomia de pensamentos. Também indicaram sua relevância por proporcionar bem-estar emocional, ser geradora de prazer, satisfação, felicidade, e melhorar a autoestima.

Tais pesquisas revelam a presença de concepções inatistas de criatividade no contexto escolar, indicam que nos espaços educativos podem existir conceitos de desenvolvimento psíquico pautados em abordagens biológicas, as quais fundamentam as crenças de que os traços genéticos determinam os processos de aprendizagem e de desenvolvimento. Para Wechsler (1998) a influência da teoria evolucionista de Darwin transformou o conceito de 
criatividade, tornando-a hereditária, algo fora do controle pessoal e transmitida internamente por códigos genéticos.

Alencar e Fleith (2003) reafirmam a possibilidade de que persistam concepções de criatividade, consideradas por elas e em nossa pesquisa, como equivocadas. Para as autoras ainda predominam entre os professores concepções errôneas de criatividade, considerando-a como um dom, um privilégio de poucos escolhidos, e presente predominantemente entre artistas, cientistas e inventores. Essa possibilidade, como afirma Anaruma (1992) e Alencar e Fleith (2003), faz com que o professor adote práticas de ensino que reforcem a não criatividade.

Nessa perspectiva, nos aproximamos de Fleith (2011), que lembra: a criatividade não se restringe a inspiração, nem significa um dom inato, ao contrário, envolve preparação, aprendizagens, oportunidades e experiências ricas e diversificadas. Além disso, acreditamos que a criatividade se constitui como um processo da subjetividade humana, na sua dupla condição de subjetividade individual e subjetividade social (MITJÁNS MARTÍNEZ, 2004, 2008a), conceito que será aprofundando em outra seção.

Em outro sentido estão os estudos que apontam a criatividade como a capacidade de transformar, de fazer e inovar, o que foi encontrado nas pesquisas de Lucilena Oliveira (2006); Libório (2009); Edileusa Oliveira (2009); Cardoso e Leite (2009); Costa Júnior (2008); Eny Oliveira e Alencar (2010); Libório e Neves (2010); Nakano (2011); Chiodi et al. (2011); e Zélia Oliveira (2012).

A forte presença dessas concepções indica a relação ainda existente no ambiente escolar entre criatividade e inovação, e, criatividade e transformação. O estudo de Lucilena Oliveira (2006) está em consonância com tal afirmativa. A autora investigou a atuação criativa em professores de educação infantil, com ênfase à autopercepção sobre criatividade, às estratégias utilizadas em sala de aula e à interação professor-aluno. Por meio da análise de questionários e observações em sala de aula de nove professores, concluiu que há algumas diferenças entre as concepções dos professores das regiões consideradas, mas que todos demonstraram fazer uso da criatividade. A concepção predominante, em relação às respostas para a pergunta: “para você, o que é a criatividade?", refere-se a inovar, com 146 escolhas, seguida de capacidade de criar, com 135.

Em seu estudo, com professores de artes, Costa Júnior (2008) também encontrou concepções de criatividade vinculadas à invenção, criação, produção de algo novo, sendo que, para os professores de sua pesquisa, todas as pessoas possuem um potencial criativo. 
Entretanto, alerta que apesar das definições apresentadas estarem de acordo com conceitos reconhecidos acerca da criatividade, aos docentes, falta embasamento teórico. Além disso, eles ainda não têm consciência crítica a respeito de seu agir criativo.

$\mathrm{O}$ autor, apesar de afirmar a necessidade de embasamento teórico, não especifica quais seriam: pedagógicos? Didáticos? Relacionados à criatividade ou a áreas específicas do conhecimento - matemática, língua portuguesa, ciências? Entretanto, o que nos fala chama a atenção para a relação entre a criatividade e os conhecimentos científicos. Aspecto que investigamos em nossa pesquisa.

Antes dessas discussões a respeito dos conhecimentos, consideramos ser pertinente entender como as concepções de criatividade são compreendidas em outros níveis e etapas de ensino, bem como em outros espaços educativos que não apenas da instituição educativa. Nessa direção, está o trabalho de Cardoso e Leite (2009), que procuraram refletir acerca do desenvolvimento da criatividade no trabalho pedagógico hospitalar. Em seus resultados verificaram que para as professoras que atuavam naquele espaço pedagógico a criatividade está associada às atitudes e capacidade de transformar, modificar situações que vivenciam diariamente, sendo vista como um dos fatores que lhes inspiravam, capacitando-as para planejar com flexibilidade em momentos imprevistos.

O estudo de Chiodi et al. (2011) possui como diferencial a investigação da concepção de criatividade de professores que atuavam em instituições educativas públicas e privadas, abrangendo tanto o ensino fundamental, como ensino médio. Dentre as suas conclusões, encontraram cinco categorias: pensar e raciocinar; fazer e transformar; memória; biológico; atitude e comportamento. Os autores afirmaram que os docentes associam a criatividade mais ao fazer e transformar.

Concepções semelhantes foram identificadas por Zélia Oliveira (2012), que investigou, na pós-graduação stricto sensu, de cursos de diferentes áreas de conhecimento, as concepções de criatividade e os procedimentos pedagógicos usados pelos docentes que proporcionavam o desenvolvimento do potencial criativo discente. Os resultados indicaram que, para estudantes e professores, a criatividade relacionava-se à inovação, quebra de padrões, vencer limites e fronteiras, solução de problemas, produtos inovadores e características das pessoas criativas, ideias que, segundo a pesquisadora, coexistem entre os especialistas da área.

Dentre tais especialistas está De La Torre $(2005,2006)$, que aponta alguns aspectos que são pautas aceitas entre os estudiosos do tema. Para ele, há certo consenso entre a comunidade científica de que a criatividade é uma atividade intrinsecamente humana, revelando-se como 
um potencial humano que envolve direcionalidade e intencionalidade. Em suas palavras: "Uma terceira referência vertebral da atividade criativa é o seu caráter transformador. Todo ato criativo é, em síntese, uma ‘transação' entre a pessoa e o meio. [...]” (DE LA TORRE, 2005, p. 58). O autor prossegue indicando que somente o homem cria e ao criar comunica sua transformação ao meio.

Em nossa pesquisa consideramos o papel transformador da criatividade no trabalho pedagógico, o que envolve mudanças em relação a práticas pedagógicas aceitas e legitimadas no contexto educacional e da instituição educativa. No entanto, evidenciamos o valor dessas mudanças para possibilitar maiores oportunidades de aprendizagem e desenvolvimento dos estudantes. De forma que, para além da transformação, enfatizamos a importância das modificações educativas em viabilizar aprendizagens.

De modo geral, os resultados discutidos nas pesquisas elencadas acima a respeito das concepções de criatividade dos professores nos permitem visualizar duas grandes divergências: a primeira entre aqueles trabalhos que afirmam que as concepções de criatividade são pautadas no senso comum e aqueles que dizem serem as concepções fundamentadas em abordagens teóricas diversas. A outra divergência está entre os estudos que colocam a influência das concepções de criatividade na prática pedagógica dos professores e aqueles que ressaltam que não há grande influência. Entretanto, algumas pesquisas concordam que as concepções de criatividade estão relacionadas ao embasamento teórico dos professores, o que possibilita a relação entre a criatividade e formação de professores.

Embora ocorram encontros e desencontros entre os resultados alcançados, consideramos a relevância dos estudos que abordam, entre os temas de estudo, a identificação das concepções de criatividade do professor. Permitem, com isso, uma compreensão geral das diferentes visões de criatividade que podem perpassar os contextos escolares. E assim, permitem a avaliação e compreensão das necessidades presentes, por exemplo, nos momentos de formação inicial e em serviço.

Contudo, do nosso ponto de vista, apenas identificar as concepções de criatividade não possibilita o entendimento da expressão criativa no trabalho pedagógico, se não há articulação com os diferentes espaços sociais que os professores estão inseridos e com as relações construídas no contexto educativo em que atua como docente. Assim como, não possibilitam, por si só, o entendimento da criatividade nos diferentes momentos da prática pedagógica.

$\mathrm{Na}$ perspectiva que assumimos, as concepções se formam nas inter-relações entre o professor e os espaços sociais de que participa. São relevantes, então, certas ampliações nas 
pesquisas que envolvem a identificação da concepção de criatividade do professor, procurando relacioná-las tanto aos estudos acerca das concepções predominantes nos contextos escolares, como da singularidade de cada professor, sua história de vida em aspectos pessoais e profissionais.

Ademais, consideramos que a concepção de criatividade dos professores não se constitui de forma isolada. Ao contrário, possui estreitas relações com a visão de mundo, a maneira de conceber o homem, a sociedade e a própria educação. Entendemos como Kaufmam et al. (2011), que, a partir da exposição de outros pesquisadores, concluem: as concepções de criatividade sofrem influências culturais no que se refere à ênfase colocada nas características individuais, presentes fortemente nas culturas ocidentais ou na identidade coletiva, mais frequente no Oriente. Por isso, partimos do princípio que as concepções são além de culturais, sociais, históricas e atuais. Aspectos que se mostram significativos também ao se tratar das barreiras ou fatores inibidores ou facilitadores da criatividade do professor.

\subsubsection{Os fatores inibidores ou facilitadores da criatividade do professor}

Identificamos como outra forte tendência de estudos os trabalhos que tratam a respeito das barreiras ou fatores inibidores ou facilitadores da expressão criativa do professor, o que compreende trinta e cinco materiais encontrados. Muitos desses estudos estão relacionados ao papel do professor para estímulo à criatividade dos estudantes, tema que compõe o próximo tópico.

Os materiais selecionados dentro dessa tendência se dividem ainda em duas direções: a) aqueles que abordam os fatores inibidores e facilitadores da criatividade do professor em seu trabalho pedagógico; e b) aqueles que apontam tais fatores para o desenvolvimento criativo dos estudantes. Nos quadros 4 e 5 sintetizamos as barreiras identificadas para professores e estudantes segundo os resultados encontrados pelos autores.

Quadro 4 - Barreiras à expressão criativa para professores segundo o que os autores encontraram em seus resultados

\begin{tabular}{|c|c|}
\hline \multicolumn{2}{|c|}{ Barreiras para a expressão criativa no contexto escolar } \\
\hline \multicolumn{2}{|c|}{ Para os professores } \\
\hline Barreiras & Autores \\
\hline - Relacionamento entre professores e estudantes & $\begin{array}{l}\text { - Mariani; Alencar (2005) } \\
\text { - Mariani (2001) }\end{array}$ \\
\hline - Concepção de criatividade & - Barreto; Martínez (2007) \\
\hline
\end{tabular}




\begin{tabular}{|c|c|}
\hline - Falta de tempo & $\begin{array}{l}\text { - Castro; Fleith (2008) } \\
\text { - Barreto; Martínez (2007) } \\
\text { - Ribeiro; Fleith (2007) } \\
\text { - Ribeiro (2006) } \\
\text { - Lima (2010) } \\
\text { - Moraes (2012) } \\
\text { - Ana Oliveira (2002) } \\
\text { - Castro (2007) }\end{array}$ \\
\hline - Sobrecarga do Currículo- trabalho & $\begin{array}{l}\text { - Libório (2009) } \\
\text { - Mariani; Alencar (2005) } \\
\text { - Mariani (2001) } \\
\text { - Ana Oliveira (2002) } \\
\text { - Tanggaard (2011) } \\
\text { - Ângela Melo (2013) } \\
\end{array}$ \\
\hline - Rotinas & • Libório (2009) \\
\hline • Elevado número de estudantes & $\begin{array}{l}\text { - Libório (2009) } \\
\text { - Carvalho (2004) } \\
\text { - Assis (2009) } \\
\text { - Godinho (2008) } \\
\text { - Souza; Alencar (2006) }\end{array}$ \\
\hline - Estrutura insuficiente & - Libório (2009) \\
\hline - Carência de recursos & $\begin{array}{l}\text { - Mariani; Alencar (2005) } \\
\text { - Mariani (2001) } \\
\text { - Gums (2003) } \\
\text { - Ana Melo (2001) }\end{array}$ \\
\hline - Indisciplina & $\begin{array}{l}\text { - Carvalho (2004) } \\
\text { - Assis (2009) }\end{array}$ \\
\hline - Dificuldades de aprendizagem & $\begin{array}{l}\text { - Carvalho (2004) } \\
\text { - Assis (2009) } \\
\text { - Godinho (2008) } \\
\text { - Souza; Alencar (2006) }\end{array}$ \\
\hline - Desinteresse dos estudantes pelo estudo - conteúdo & $\begin{array}{l}\text { - Carvalho (2004) } \\
\text { - Godinho (2008) }\end{array}$ \\
\hline - Ausência de apoio da direção - coordenação & - Ana Oliveira (2002) \\
\hline
\end{tabular}

Fonte: a autora (2014).

Quadro 5 - Barreiras à expressão criativa dos estudantes segundo o que os autores encontraram em seus resultados

\begin{tabular}{|c|c|}
\hline \multicolumn{2}{|c|}{ Barreiras para a expressão criativa no contexto escolar } \\
\hline \multicolumn{2}{|c|}{$\begin{array}{l}\text { Para os estudantes } \\
\end{array}$} \\
\hline Barreiras & $\begin{array}{r}\text { Autores } \\
\end{array}$ \\
\hline - Elevado número de estudantes em sala de aula & $\begin{array}{l}\text { - Alencar; Fleith (2010) } \\
\text { - Maria Souza (2004) } \\
\text { - Maria Souza; Alencar (2006) } \\
\text { - Carvalho (2004) } \\
\text { - Christina Silva (2007) }\end{array}$ \\
\hline - As situações de indisciplina & - Carvalho (2004) \\
\hline - Dificuldades de aprendizagem & $\begin{array}{l}\text { - Alencar e Fleith (2010) } \\
\text { - Maria Souza (2004) } \\
\text { - Maria Souza; Alencar (2006) } \\
\text { - Carvalho (2004) }\end{array}$ \\
\hline - Desinteresse dos estudantes & $\begin{array}{l}\text { - Alencar; Fleith (2010) } \\
\text { - Maria Souza (2004) } \\
\text { - Maria Souza; Alencar (2006) } \\
\text { - Carvalho (2004) } \\
\text { - Christina Silva (2007) } \\
\end{array}$ \\
\hline
\end{tabular}




\begin{tabular}{|c|c|}
\hline - Desvalorização do papel do professor & - Carvalho (2004) \\
\hline - Escassez de material didático & $\begin{array}{l}\text { - Schirmer (2001) } \\
\text { - Carvalho (2004) }\end{array}$ \\
\hline $\begin{array}{l}\text { - Poucas oportunidades para } \\
\text { extraclasse }\end{array}$ & - Carvalho (2004) \\
\hline $\begin{array}{l}\text { - Poucas oportunidades para trocar ideias com colegas } \\
\text { professores }\end{array}$ & $\begin{array}{l}\text { - Alencar; Fleith (2010) } \\
\text { - Carvalho (2004) }\end{array}$ \\
\hline - Limites e regras impostos pelo professor & - Schirmer (2001) \\
\hline - Falha na formação & - Lima (2010) \\
\hline - Medo de se expressar & - Lima (2010) \\
\hline
\end{tabular}

A construção a respeito dessas duas possibilidades de estudo das barreiras ou fatores inibidores à criatividade do professor indica que as pesquisas vinculadas à criatividade docente precisam ser analisadas com cuidado, pois, apesar de anunciarem o interesse pela expressão criativa do professor, podem ter como foco efetivo a criatividade discente.

Há também aqueles estudos que envolvem as duas perspectivas, como a tese de doutorado de Schirmer (2001), que investigou de forma mais ampla os fatores que impedem o emprego da criatividade em sala de aula. Em seus resultados encontrou indicações que envolviam as condições físicas do espaço escolar, no que se refere aos locais adequados para expressão criativa dos estudantes, a falta de materiais, recursos e apoio técnico. A pesquisadora obteve, ainda, respostas relacionadas às lacunas na formação e motivação do professor, a repressão às respostas criativas dos estudantes, bem como os limites e regras que impõe a eles.

No contexto da prática pedagógica, Carvalho (2004) possuía como objetivo investigar os componentes que contribuem para favorecer ou inibir a criatividade dos estudantes, de acordo com professores de geografia de $5^{\mathrm{a}}$ a $8^{\mathrm{a}}$ séries do ensino fundamental, verificando as possíveis diferenças entre docentes de instituições públicas e particulares. Em sua pesquisa, constatou que as barreiras mais indicadas estão associadas ao elevado número de estudantes em sala de aula, as situações de indisciplina, as dificuldades de aprendizagem e desinteresse apresentados por eles; a desvalorização do papel do professor; a escassez de material didático; as poucas oportunidades para realizar atividades extraclasse e para trocar ideias com colegas professores.

Por outro lado, o estudo de Tanggaard (2011), no contexto dinamarquês, indicou que, dentre as barreiras à criatividade do professor, está o dilema vivido entre a demanda que os docentes possuem advinda do sistema de avaliações e os desafios que as sociedades colocam 
em relação à educação. E mais, aponta que o ensino orientado por meio de projetos educativos não representa um "oásis" de criatividade para os professores e alunos.

Tais aspectos chamam a atenção para os fatores que têm dificultado a expressão criativa dos estudantes, segundo os professores, os quais envolvem diferentes etapas de ensino, como na educação infantil: Assis (2009); no ensino fundamental: Libório (2009), Libório e Neves (2010), Alencar e Fleith (2008); no ensino médio: Christina Silva (2007); no ensino superior: Alencar e Fleith (2010), Maria Souza (2004), Souza e Alencar (2006); na pós-graduação: Lima (2010), na educação de jovens e adultos: Gums (2003), e com diferentes etapas: Godinho (2008), Aljughaiman (2002).

Para Alencar (2001), as barreiras à expressão criativa dos estudantes se revelam em aspectos que perpassam os espaços escolares e as práticas de ensino, as quais dificultam e, por vezes, inviabilizam o desenvolvimento da criatividade. Dentre os aspectos discutidos pela autora, estão: a presença de currículos rígidos; a postura autoritária de muitos docentes; a falta de integração entre as distintas disciplinas; a ênfase exagerada na reprodução de conhecimentos, em respostas "certas", na obediência e passividade; e um ensino marcadamente livresco.

Esses elementos destacados por Alencar (2001) aproximam-se da valorização excessiva do raciocínio lógico, em detrimento das situações de fantasias e imaginação; aspectos que, em conjunto, evidenciam determinadas condições de ensino, as quais têm caracterizado os processos de ensino e de aprendizagem, segundo diferentes estudiosos da área de criatividade, como Gravié (2008), Virgolim (2007), Fleith (2007) e Wechsler (2002). Esses fatores situamse como inibidores da expressão criativa em diferentes direções, tanto para os estudantes em seus processos de aprendizagem, como para os professores no trabalho pedagógico e a instituição educativa como organização.

De forma mais específica, Mariani (2001) e Mariani e Alencar (2005) estudaram os componentes da organização do trabalho pedagógico e os elementos de caráter pessoal/individual que agem como inibidores e facilitadores da expressão criativa do professor, considerando aqueles que atuam em história de $5^{\mathrm{a}}$ à $8^{\mathrm{a}}$ série (ensino fundamental de oito anos). Em relação aos limites apontados por elas estão: problemas na relação professoraluno, a falta de motivação e participação dos estudantes nas aulas, a responsabilidade ou compromisso, a imaturidade que apresentam, as brincadeiras em sala, sobrecarga de trabalho, a estrutura escolar, dentre outros. 
Estas autoras identificaram uma diversidade de fatores que podem trazer estímulos à criatividade do professor, como liberdade de atuação, desinibição, paixão pelo trabalho, acesso aos recursos materiais, trabalho em equipe, orientação efetiva, boa relação professoraluno. Tais fatores facilitadores se relacionam ao que outras pesquisas encontraram ao investigarem semelhante tema, como os resultados de: Ana Melo (2001), Ana Oliveira (2002), Alencar e Fleith (2003), Barreto e Martínez (2007).

Considerando os diferentes níveis de ensino, Alencar e Fleith (2003) utilizaram um instrumento que incluía itens relacionados a: Inibição/Timidez, Falta de Tempo/Oportunidade, Repressão Social e Falta de Motivação, tendo em vista os fatores que se configuram como barreiras para expressão criativa dos professores. As autoras chegaram à conclusão de que há distintas barreiras que se referem direta ou indiretamente aos motivos, meios e oportunidades para a expressão da criatividade pessoal dos professores, o que indica a necessidade de estratégias que ampliem as suas possibilidades de expressão criativa. Diferenças significativas foram observadas entre professores do sexo masculino e feminino somente nos itens relativos à Repressão Social e, entre professores de diferentes níveis de ensino, nos fatores vinculados à Inibição/Timidez e Repressão Social.

Nessa direção, encontram-se os resultados de Castro (2007) e Castro e Fleith (2008), as quais, em relação ao tempo de docência na $4^{\mathrm{a}}$ série do ensino fundamental e às barreiras pessoais à criatividade do professor, concluíram divergência significativa em apenas uma medida de criatividade entre professores com mais e menos tempo de atuação, que é a flexibilidade. Em relação às barreiras, não foi identificada diferença significativa entre os professores nos diversos fatores examinados, sendo que a barreira que obteve maior média nos dois grupos foi falta de tempo/oportunidade. Esse fator foi encontrado também por Ana Oliveira (2002), Ribeiro (2006) e Ribeiro e Fleith (2007), Lima (2010) e Moraes (2012).

Essa barreira relacionada ao tempo mostrou-se presente também no estudo de Kinney (2005), que se centrou em possíveis diferenças entre os fatores inibidores da expressão criativa no contexto escolar de espaços escolares de japoneses e norte-americanos. Nessa pesquisa, partiu-se do princípio de que os fatores culturais poderiam interferir na criatividade e nas barreiras a sua promoção. No entanto, os resultados apresentados indicaram que não ocorreram diferenças significativas e que, para professores americanos, predominam os fatores da falta de tempo e elementos externos, enquanto os professores japoneses assumem a responsabilidade para si próprios. 
Com base nos estudos citados é possível observar os diferentes fatores que podem se configurar como inibidores e facilitadores para a expressão criativa no contexto escolar. Nas pesquisas de Mitjáns Martínez (2008a) predominaram as chamadas barreiras pessoais. Eny Oliveira (2007) e Eny Oliveira e Alencar (2010) encontraram aspectos de natureza pessoal e pedagógica, e aqueles que podem ser categorizados como de natureza administrativa, como número de estudantes por turma e por professor, acesso aos recursos materiais, a organização do tempo, dentre outros. Tais fatores apresentam semelhanças e diferenças nas etapas de ensino e têm nos elementos pessoais e nas relações professor-aluno as maiores indicações.

Superando a descrição de fatores ou elementos inibidores, estão as afirmações de Castro (2007), Castro e Fleith (2008) e Alencar e Fleith (2003). As conclusões que as autoras alcançaram nos permitem evidenciar que as barreiras à expressão criativa do professor, propriamente, precisam estar situadas na singularidade dos indivíduos que compõem a dinâmica educativa e nos aspectos constitutivos do espaço escolar. A respeito, concordamos com o que afirma Mitjáns Martínez (2008a, p. 84):

[...] a caracterização de um elemento como favorecedor ou como inibidor da criatividade não pode ser feita de forma universal à margem dos sujeitos que são quem as percebe de uma ou outra forma, reforçando a ideia de que a criatividade, em qualquer área, constitui uma expressão de complexas configurações do sujeitocontexto, nas quais a dimensão subjetiva - social e individual - emerge como essencial.

As informações apresentadas nas pesquisas, ao afirmarem a diversidade de fatores que podem interferir na criatividade no contexto escolar, possibilitam a compreensão de que a criatividade precisa ser considerada tendo em vista o professor, o espaço social onde está inserido e as relações sociais construídas no contexto educativo (com outros professores, estudantes, famílias). Por isso, para alguns professores, os processos relacionais entre eles e seus estudantes podem se tornar tanto instigadores, como barreiras à sua criatividade no trabalho pedagógico.

Isso remete à consideração das especificidades das dimensões do social para a expressão criativa do professor. Para Mitjáns Martínez (2004), a dimensão relacional do social é fundamental para a compreensão da criatividade, pois é por meio da relação com o outro que se constitui a subjetividade individual, em termos do sujeito e sua personalidade. Como parte da personalidade, constituem-se também as configurações criativas, que abrangem o conjunto de recursos subjetivos que se atualizam na ação criativa.

Ademais, faz-se relevante considerar, ainda, as formações motivacionais dos professores, as quais tendem a desempenhar um papel maior na expressão criativa no campo profissional, conforme afirma Mitjáns Martínez (2003a). Em tais formações evidencia-se a 
relação intrínseca entre a cognição e o afeto, em cuja união, como diz a autora, se configura como célula essencial da regulação do comportamento criativo, e em cuja unidade se define a qualidade do ato criativo e suas regularidades.

Essa unidade entre cognição e afeto pode, por vezes, ser desconsiderada nos estudos que se direcionam aos fatores inibidores à criatividade, repercutindo nas relações entre o indivíduo e o ambiente. Nessa perspectiva, concordamos com Bruno-Faria et al. (2008, p. 158) quando afirmam que:

No que se refere às condições do trabalho propícias à criatividade, nota-se também que quase sempre é um ambiente considerado como universal, isto é, os estímulos e as barreiras são os mesmos para quaisquer tipos de indivíduos e organizações. Novamente se percebe que a tal interação entre aspectos do indivíduo e do ambiente é negligenciada.

Atrelada à desarticulação entre o indivíduo e o ambiente está a busca por regularidades, leis que gerenciam os comportamentos humanos e, consequentemente, indicam aqueles fatores que seriam facilitadores ou inibidores da criatividade do professor na organização do trabalho pedagógico. Nessa direção, Mitjáns Martínez (2005, p. 16) esclarece que o "princípio da ordem" diz respeito à concepção do determinismo dos fenômenos e se expressa na procura por regularidades, do que é comum, procurando de forma, também, determinista encontrar ou “[...] estabelecer relações de causa e efeito entre estímulos ou condições e processos psicológicos".

Além disso, compreendemos que as barreiras mais difíceis de superar são aquelas que predominam no sistema de crenças e valores que integram a instituição educativa, a estrutura do sistema educacional, e a forma como os indivíduos reagem diante das adversidades docentes (MITJÁNS MARTÍNEZ, 2008a). Entender a dimensão social da expressão criativa no trabalho pedagógico requer esse olhar cuidadoso ao se referir aos fatores que podem se constituir como inibidores ou facilitadores da criatividade, rompendo com visões universais e padronizadas.

Nota-se, portanto, a importância de estudos acerca da criatividade no trabalho pedagógico do professor que considerem, no processo de pesquisa, o docente como indivíduo real e em contexto, o qual a partir de suas relações sociais e história de vida única e singular pode indicar as barreiras à sua criatividade e se há fatores que podem ser considerados como facilitadores. 


\subsubsection{O papel do professor para o desenvolvimento da criatividade dos estudantes}

Outra tendência de estudo muito presente na literatura e nas pesquisas a respeito da criatividade do professor refere-se aos trabalhos que discorrem sobre o papel docente para estímulo à criatividade dos estudantes, os quais representam quarenta e dois materiais selecionados. Tais produções estão muito próximas das que procuraram a identificação das barreiras ou fatores inibidores e facilitadores da criatividade do professor, mas podem ser encontrados separadamente.

A respeito dos trabalhos que se voltam para o papel do professor para o estímulo à criatividade, identificamos que eles se dividem entre aqueles que oferecem maior ênfase para: a) características docentes facilitadoras da criatividade dos estudantes; b) procedimentos que podem estimular a expressão criativa discente; c) instrumentos de avaliação quanto ao estímulo à criatividade; d) clima ou ambiente favorável à criatividade dos estudantes. $\mathrm{O}$ quadro 6 identifica os autores que tratam de tais temáticas.

\begin{tabular}{|c|c|}
\hline \multicolumn{2}{|c|}{ Papel do professor para estímulo à criatividade } \\
\hline Temáticas abordadas & $\begin{array}{c}\begin{array}{c}\text { Autores que trataram dessas } \\
\text { abordagens }\end{array} \\
\end{array}$ \\
\hline Características do professor facilitador & $\begin{array}{l}\text { - Assis (2009) } \\
\text { - Dulce Souza (2005) } \\
\text { - Santeiro et al. (2004) } \\
\text { - Alencar; Fleith (2004) } \\
\text { - Teixeira (2000) } \\
\end{array}$ \\
\hline Procedimentos, métodos e estratégias & $\begin{array}{l}\text { - Meyer (2012) } \\
\text { - Eyster (2010) } \\
\text { - Crowe (2010) } \\
\text { - Casangiu (2010) } \\
\text { - Gibson (2010) } \\
\text { - Gravié (2008) } \\
\text { - Puccio et al. (2008) } \\
\text { - Jeffrey (2006) } \\
\text { - White (2006) } \\
\text { - Alencar; Fleith (2003) } \\
\text { - Godinho (2008) } \\
\text { - Almeida (2007) } \\
\text { - Eny Oliveira; Alencar (2010) } \\
\text { - Christina Silva (2007) } \\
\text { - Carvalho (2004) } \\
\text { - Ana Oliveira (2002) }\end{array}$ \\
\hline Clima ou ambiente & $\begin{array}{l}\text { - Trevor (2006) } \\
\text { - Fleith (2007) } \\
\text { - Cagle (2002) }\end{array}$ \\
\hline Avaliação de professores e estudantes quanto ao estímulo à criatividade & $\begin{array}{l}\text { - Aquino (2012) } \\
\text { - Godinho (2008) } \\
\text { - Ribeiro; Fleith (2007) } \\
\text { - Almeida (2007) } \\
\text { - Maria Souza; Alencar (2006) } \\
\text { - Ribeiro (2006) } \\
\text { - Onã Silva; Alencar (2003) }\end{array}$ \\
\hline
\end{tabular}




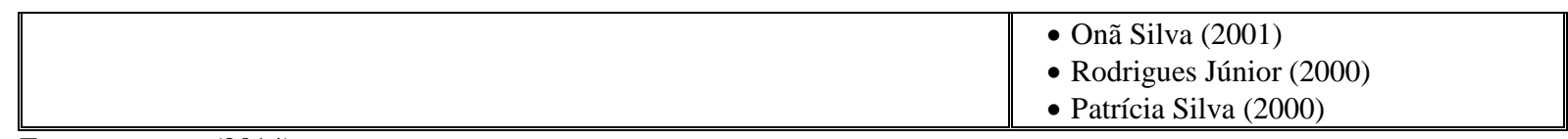

Fonte: a autora (2014).

$\mathrm{Na}$ educação infantil, Assis (2009) investigou os atributos pessoais docentes considerados importantes para a promoção da criatividade nos estudantes e as práticas pedagógicas utilizadas para favorecer a expressão criativa. Em sua pesquisa com professores de instituições privadas de ensino, encontrou atributos relacionados à responsabilidade, domínio do conteúdo desenvolvido, dedicação ao trabalho. Em relação às práticas, verificou que todos os participantes do estudo declararam usar práticas pedagógicas que proporcionam o desenvolvimento da criatividade em sala de aula, estando essas práticas relacionadas aos estudantes, atividades lúdicas e interações em grupo.

No âmbito do ensino superior situa-se a pesquisa realizada por Santeiro et al. (2004), que procuraram caracterizar o professor universitário que, segundo seus estudantes, podem ser considerados como facilitadores ou inibidores de sua expressão criativa. Em seus achados verificaram a predominância de elementos vinculados ao preparo do professor, seguidos dos que indicam a forma como ele se relaciona com os estudantes. Os traços de personalidade e técnicas instrucionais tiveram os menores índices.

Alencar e Fleith (2004), também no ensino superior, procuraram desenvolver um inventário de práticas docentes que favorecem a criatividade nessa etapa de ensino. Para isso, realizaram uma pesquisa com o objetivo de construir e validar um instrumento que possibilitasse avaliar a percepção de estudantes universitários quanto à extensão em que seus professores apresentavam comportamentos, e implementavam práticas docentes que favorecessem o desenvolvimento e a expressão da criatividade dos estudantes.

Foram trabalhados quatro fatores: Incentivo a Novas Ideias, Clima para Expressão de Ideias, Avaliação e Metodologia de Ensino e Interesse pela Aprendizagem do Aluno, os quais dizem respeito a distintos atributos do professor facilitador da expressão criativa de seus estudantes. Os resultados sugeriram que o inventário de práticas docentes se mostrou como um instrumento útil para fins de pesquisa e identificação de condutas docentes que favorecem o desenvolvimento e expressão criativa dos estudantes.

O foco de Dulce Souza (2005) também estava no ensino superior, no entanto, concentrou-se nas práticas avaliativas e na extensão em que poderiam favorecer o desenvolvimento e a expressão da criatividade dos estudantes do curso de Pedagogia. Na análise de sua pesquisa encontrou que, para professores e estudantes, as práticas avaliativas utilizadas contemplavam a expressão e o desenvolvimento criativo. 
Sem especificar as etapas de ensino, Alencar e Fleith (2003) trouxeram contribuições de diferentes estudiosos do tema da criatividade (como, Cropley, Torrance e Renzulli) para tratar a respeito do professor propiciador do desenvolvimento da criatividade. Citam aspectos vinculados ao envolvimento, motivação, determinação, curiosidade, autoconfiança, valorização de pensamento flexível, autoavaliação e conhecimento da disciplina, atributos que, de certa forma, aproximam-se do perfil do professor criativo, citados em outra seção.

No quadro 7 está a síntese das características citadas em alguns dos estudos apresentados anteriormente.

Quadro 7 - Características do professor facilitador da criatividade dos estudantes e os autores que as identificaram

\begin{tabular}{|c|c|}
\hline Características do professor facilitador & Autores que identificaram tais características \\
\hline - Responsabilidade & • Assis (2009) \\
\hline - Domínio do conteúdo desenvolvido & - Assis (2009) \\
\hline - Dedicação ao trabalho & - Assis (2009) \\
\hline - Preparo do professor & $\begin{array}{l}\text { - Santeiro et al. (2004) } \\
\text { - Teixeira (2000). }\end{array}$ \\
\hline - Relacionamento com os estudantes & - Santeiro et al. (2004) \\
\hline - Envolvimento & - Alencar; Fleith (2003) \\
\hline - Motivação & - Alencar; Fleith (2003) \\
\hline - Determinação & - Alencar;Fleith (2003) \\
\hline - Curiosidade & - Alencar; Fleith (2003) \\
\hline - Autoconfiança & - Alencar; Fleith (2003) \\
\hline - Valorização do pensamento flexível & - Alencar; Fleith (2003) \\
\hline - Autoavaliação & - Alencar; Fleith (2003) \\
\hline - Conhecimento da disciplina & - Alencar; Fleith (2003) \\
\hline
\end{tabular}

Fonte: a autora (2014).

Além das características do professor facilitador da criatividade, alguns estudos se dedicaram a analisar os procedimentos utilizados pelos professores que podem favorecer o desenvolvimento criativo dos estudantes. Nesses estudos estão situados os trabalhos de Godinho (2008), Almeida (2007), Eny Oliveira e Alencar (2010), Christina Silva (2007), Carvalho (2004) e Ana Oliveira (2002).

Dentre os resultados das pesquisas apresentadas, encontram-se referências à importância da relação professor-aluno, estímulo para os estudantes analisarem diferentes aspectos de um problema, esclarecimento de dúvidas, desenvolvimento da capacidade crítica, a condução para que o estudante perceba e conheça os pontos de vista divergentes acerca do mesmo problema ou tema de estudo e incentivo a novas ideias.

Os procedimentos apresentados pelas pesquisas aproximam-se dos estudos que focam os métodos, práticas e estratégias de ensino que podem favorecer o desenvolvimento criativo dos estudantes. Nesses estudos situam-se os trabalhos de Meyer (2012); Eyster (2010); Crowe 
(2010); Casangiu (2010); Gibson (2010); Gravié (2008); Puccio et al. (2008); Jeffrey (2006); White (2006); Alencar e Fleith (2003). As alternativas que os autores sugerem compreendem discussões em torno da aprendizagem cooperativa, resolução de problemas, adaptação de atividades e laboratórios para as aulas de ciências, aprendizagem por meio da ação e envolvimento com as propostas de estudos, dentre outros tantos aspectos elencados por eles.

O estudo de Vieira e Martins (2013) não apontou métodos ou estratégias que promovessem a criatividade dos estudantes, mas buscou compreender como o processo de formação pode contribuir para a expressão criativa de profissionais da educação, tendo em vista a efetivação da inclusão escolar. Em sua análise, encontraram que nem todas as participantes do curso, oferecido na pesquisa-ação, produziram estratégias criativas em decorrência desse espaço formativo, embora algumas tenham desenvolvido alternativas criativas significativas. Entenderam, em sua construção, que um processo de formação "poderá contribuir para a expressão criativa se considerar e intervir na dimensão pessoal dos participantes, impulsionando o desenvolvimento de elementos subjetivos que a favoreçam, bem como a assunção da condição de sujeito.” (VIEIRA; MARTINS, 2013, p. 225), aspectos a que nos aproximamos em nosso estudo.

No quadro 8 encontram-se alguns dos procedimentos, métodos e estratégias citadas por autores apresentados acima.

Quadro 8 - Procedimentos, métodos e estratégias que estimulam a criatividade dos estudantes e os autores que as identificaram

\begin{tabular}{||l||l||}
\hline \multicolumn{1}{|c|}{ Procedimentos, métodos e estratégias } & Autores que abordaram as temáticas \\
\hline \hline Incentivo a novas ideias & $\bullet$ Godinho (2008) \\
& $\bullet$ Christina Silva (2007) \\
\hline $\begin{array}{l}\text { Estímulo para os estudantes analisarem diferentes aspectos de um } \\
\text { problema }\end{array}$ & $\bullet$ Almeida (2007) \\
\hline $\begin{array}{l}\text { Levar o aluno a perceber e conhecer os pontos de vista divergentes } \\
\text { sobre o mesmo problema ou tema de estudo }\end{array}$ & $\bullet$ Almeida (2007) \\
\hline Incentivo à autoconfiança do estudante & $\bullet$ Christina Silva (2007) \\
\hline Interesse pela aprendizagem do estudante & $\bullet$ Carvalho (2004) \\
\hline Contextualizar os conteúdos & $\bullet$ Christina Silva (2007) \\
\hline Utilizar exemplos & $\bullet$ Carvalho (2004) \\
\hline Aprendizagem cooperativa & $\bullet$ Gravié (2008) \\
\hline Adaptação de atividades e laboratórios para as aulas de ciências & $\bullet$ Meyer (2012) \\
\hline Relação professor-aluno & $\bullet$ Eyster (2010) \\
\hline $\begin{array}{l}\text { Aprendizagem por meio da ação e envolvimento com as propostas de } \\
\text { estudos }\end{array}$ & $\bullet$ Ana Oliveira (2002) \\
\hline Capacidade crítica & $\bullet$ Carvalho (2004) \\
\hline Diferentes pontos de vista & $\bullet$ Carvalho (2004) \\
\hline Esclarecimentos de dúvidas & $\bullet$ Crowe (2010) \\
\hline $\begin{array}{l}\text { Fonte: a autora (2014) } \\
\text { Carvalho (2004) }\end{array}$ \\
\hline
\end{tabular}

Fonte: a autora (2014). 
Existem ainda aqueles estudos que trazem a avaliação de professores e estudantes quanto ao estímulo à criatividade, como os de: Aquino (2012), Godinho (2008), Ribeiro e Fleith (2007), Almeida (2007), Maria Souza e Alencar (2006), Ribeiro (2006), Onã Silva e Alencar (2003), Onã Silva (2001), Rodrigues Júnior (2000), Patrícia Silva (2000). Nesses estudos há divergências entre o que os professores afirmam - para a maioria, eles são criativos e estimulam a criatividade discente - e o que os estudantes dizem - são poucos estímulos e são eles que apresentam mais criatividade do que seus professores.

Outras divergências foram identificadas entre os resultados das pesquisas de Zélia Oliveira (2012), Maria Souza (2004), Maria Souza e Alencar (2006), que afirmam: para a maioria dos professores participantes de seus estudos há relação entre ensino de forma criativa e o desenvolvimento da criatividade dos estudantes, para as últimas autoras, há relações, também, entre criatividade, aprendizagem e desempenho escolar. E, as colocações de Moraes (2012): para a quase totalidade dos professores pesquisados, o seu ensino era criativo, no entanto, eles não percebiam como criativos os textos produzidos pelos alunos.

O estudo de Ângela Melo (2013) sugere outra perspectiva. Para os professores e estudantes do $7^{\circ}$ ano do ensino fundamental de três instituições particulares do Distrito Federal, os docentes utilizavam práticas pedagógicas que favoreciam a criatividade dos alunos, embora tivessem pouco conhecimento a esse respeito. Os discentes concordam que há incentivos para sua expressão criativa em Língua Portuguesa e Matemática.

No ensino médio, Otaviano et al. (2012) identificaram diferenças significativas entre alunos de instituições públicas e particulares quanto às práticas utilizadas por professores que promovem a criatividade dos estudantes, a favor daqueles de instituições particulares. Constatou, também, relação significativa entre a percepção dos alunos quanto ao uso de estratégias para desenvolver a criatividade e a motivação dos estudantes em matemática.

Esse maior interesse pela aprendizagem foi, segundo Edileusa Oliveira e Alencar (2012), destacado pelos coordenadores pedagógicos que participaram de seu estudo. Profissionais esses que acreditam na importância da criatividade do professor por motivos relacionados aos alunos, em especial, por possibilitar maior estímulo, atribuição de significado ao conhecimento e, com isso, facilitar a aprendizagem.

$\mathrm{Na}$ perspectiva que assumimos, não consideramos uma relação direta entre a criatividade no trabalho pedagógico e o desenvolvimento da expressão criativa nos estudantes, apesar de poder existir uma relação possível, inclusive, quanto ao interesse deles 
em sua aprendizagem. Compreendemos que a criatividade abrange a forma como, tanto o professor, quanto o aluno, vivenciam e outorgam valor às suas diversas experiências educativas, constituindo-se como um processo que envolve diferentes fatores: sociais, históricos, atuais, culturais, subjetivos.

Apesar disso, entendemos que um professor que expressa criatividade no trabalho pedagógico promove situações educativas que proporcionam avanços na aprendizagem, e pode ser ainda mais sensível aos processos criativos na aprendizagem, reconhecendo-os como legítimos e instigando-os em seus estudantes. Nisso concordamos com Mitjáns Martínez (2008b), para favorecer o desenvolvimento da criatividade de forma efetiva nos estudantes é preciso trabalhar, em alguma medida, de forma criativa.

Reconhecemos a importância de um meio social que contribua para a expressão criativa. Podem contribuir, portanto, os trabalhos que versam sobre o clima ou ambiente que favorece o desenvolvimento da criatividade dos estudantes, como os de Trevor (2006), Fleith (2007) e Cagle (2002). Nessas produções são feitas referências diversas, dentre elas: à valorização de produtos e ideias criativas, oferecimento de oportunidades de escolhas, relações entre os objetivos de ensino e as experiências pessoais dos estudantes, apoio ao trabalho de grupo, liberdade de expressão, aspectos semelhantes aos que foram apresentados anteriormente acerca do ensino criativo.

A propósito dos elementos que podem interferir para que o professor seja um facilitador da criatividade dos estudantes, Schirmer (2001) concluiu, em sua pesquisa, que as ações pedagógicas das professoras pesquisadas estavam fortemente condicionadas pelas representações construídas em sua vida acadêmica ou no contato com modelos didáticos que convivem em sua prática. E que a formação docente pode se situar entre as dificuldades para a criatividade do professor no contexto escolar.

A identificação dessa "dificuldade" para promoção da criatividade no contexto escolar chama a atenção para a relação entre criatividade e formação. Assunto este que permeia a dissertação de Ussene (2006), o qual teve como objetivo analisar o processo de formação de professores em exercício do Instituto de Magistério Primário da Matola (Moçambique), tendo em vista o desenvolvimento de uma postura criativa e reflexiva desses formandos e, consequentemente, melhoria da qualidade do ensino. O autor partiu do princípio de que o desenvolvimento de posturas criativas ao longo da formação profissional poderia implicar condições para práticas futuras e, assim, os formandos poderão despertar e desenvolver em seus estudantes atitudes criativas e reflexivas. 
Contudo, com base em sua análise, Ussene (2006) constatou que a criatividade e a reflexividade não fazem parte do processo de ensino e aprendizagem da instituição de ensino superior, nem da instituição onde os formandos-professores atuavam. E mais, a relação teoria e prática é realizada sem que professores e estudantes tenham consciência plena da verdadeira interligação entre esses elementos.

Nessa perspectiva, Mitjáns Martínez (2008a) alerta que os professores tendem a reproduzir em seu trabalho docente o que vivenciaram em sua trajetória como estudantes e aprenderam no sistema de ensino. Além disso, destaca que nos cursos de formação de professores é reforçado de múltiplas formas, geralmente implícitas, “[...] um aprendizado sobre o que é ser professor e de como se ensina, que realmente pouco tem a ver com a criatividade.” (MITJÁNS MARTÍNEZ, 2008a, p. 81).

Atrelados às colocações de Mitjáns Martínez, estão os estudos de Alencar e Fleith (2003) no ensino superior. Para as autoras, para promover a expressão criativa nas instituições educativas, faz-se necessário formar adequadamente os professores nessa perspectiva, de maneira que eles utilizem atividades junto aos seus estudantes que possibilitem o exercício do seu pensamento criativo, além de proporcionar um clima em sala de aula que envolva a valorização e apoio à criatividade.

A respeito dessa relação entre formação docente e criatividade, De La Torre (2005, p. 40) alerta que "[...] se quisermos que a criatividade faça parte da educação, temos que antes formar os professores nela, atendendo às três dimensões de conhecimento, habilidades e atitudes". Os autores, assim, ressaltam o papel da formação de professores para o desenvolvimento da criatividade dos estudantes, contemplando em seu currículo aspectos que permitam aos futuros docentes compreenderem e estimularem a expressão criativa em sala de aula.

Consideramos a função relevante da formação docente para maior possibilidade de valorização e participação dos professores nos processos criativos de seus estudantes. Isso nos possibilitou "hipotetizar" que, dentre os processos que configuram a criatividade no trabalho pedagógico do professor, estão os conhecimentos, o saber sistematizado. Em nossa pesquisa, tivemos em vista uma maior aproximação ao tema, permitindo, com isso, identificar aqueles conhecimentos que participam da expressão criativa no trabalho pedagógico.

Além da formação docente e dos conhecimentos mobilizados na expressão criativa, compreendemos também que, na relação entre o docente e seus estudantes podem se estabelecer laços de confiança e amizade que favoreçam o desenvolvimento da criatividade. 
Mas podem existir outros fatores externos à relação professor-aluno e experiências para além do contexto escolar que dificultem a expressão criativa dos estudantes.

Nessa direção, na análise do papel do professor para a criatividade dos estudantes, torna-se importante considerar outros processos relacionados às experiências pessoais dos discentes. As relações com outros colegas, a sua história de vida, os meios sociais de que participam e, especialmente, a família são aspectos que, segundo o nosso ponto de vista, podem repercutir no desenvolvimento da criatividade, que não dependeria de maneira exclusiva do professor.

No próximo tópico nos aproximaremos dos estudos que se direcionaram a criatividade no trabalho pedagógico do professor e que se voltaram, mais especificamente, para a expressão criativa do docente no curso das práticas educativas.

\subsection{Os estudos realizados acerca da criatividade no trabalho pedagógico}

$\mathrm{Na}$ pesquisa bibliográfica realizada foram identificados apenas oito materiais que focam a criatividade no trabalho pedagógico, que envolvam, efetivamente, a consideração da importância da criatividade nas diferentes dimensões da prática educativa. Um livro traz contribuições ao tema (MITJÁNS MARTÍNEZ, 2003a), dois capítulos de livros (MITJÁNS MARTÍNEZ, 2008a; 2008b), e um artigo que aborda a temática (MITJÁNS MARTÍNEZ, 2002).

Em nível de mestrado foram identificadas três pesquisas que estudaram a expressão criativa no ensino fundamental e na educação infantil, e compreendem as pesquisas de Cores (2006), Arruda (2007) e Távora (2010). Em nível de doutorado, identificamos o trabalho de Fernandes (2011).

Nesse estudo mais recente, Fernandes (2011) procurou explicitar as manifestações da criatividade no trabalho do professor de artes visuais no ensino médio, no contexto da educação inclusiva. Com base em sua análise, a autora afirmou que essas manifestações criativas são constituídas de dilemas que oscilam entre os aspectos de sua expressão, que foram naturalizados e cristalizados no trabalho pedagógico, e as expectativas daqueles professores que procuram condições para o desenvolvimento e expressão da criatividade no espaço escolar.

Os resultados da pesquisa de Fernandes (2011) evidenciam que a criatividade no trabalho pedagógico é um processo complexo, no qual participam diferentes elementos: sociais, históricos, contextuais, subjetivos, dentre outros. E mais, indica que nos espaços 
institucionais a expressão criativa no trabalho pedagógico mostra-se em seu caráter subversivo, oferecendo alternativas às práticas naturalizadas e legitimadas socialmente naquele contexto.

Nisso aproximam-se das construções de Távora (2010), que, no âmbito da alfabetização, buscou evidenciar em que circunstâncias se expressam a criatividade no trabalho pedagógico de professores alfabetizadores, bem como, os elementos subjetivos que contribuem para explicar a expressão dessa criatividade. Em seus resultados constatou que a criatividade dos professores acontece em momentos caracterizados como transgressores, rompendo com o que está estabelecido pela instituição. Para a pesquisadora, isso se deve ao conjunto de crenças e valores presentes no espaço escolar, ao pouco hábito da leitura e ao clima emocional desfavorável vivenciado pelos docentes.

Fundamentada na mesma abordagem teórica de Távora (2010), que compreende a criatividade como processo complexo da subjetividade humana, Arruda (2007) investigou, no desenvolvimento do currículo, a expressão da criatividade do professor na perspectiva da qualidade da educação infantil. Em suas conclusões verificou que a participação dos professores na construção do currículo e os processos de reflexão envolvidos nesse processo foram importantes para que os docentes pudessem ser criativos em suas práticas educativas. Esses momentos também participaram da constituição da função pedagógica da educação infantil naquele espaço social, dos critérios definidores da criatividade do professor no contexto educativo e da construção do significado da qualidade da educação infantil.

A pesquisa realizada por Cores (2006) procurou identificar como professores de uma instituição educativa em situação de inclusão escolar organizam e desenvolvem o trabalho pedagógico a fim de favorecerem a aprendizagem e desenvolvimento dos estudantes com necessidades educacionais especiais. A análise permitiu à pesquisadora afirmar que as professoras que compuseram o estudo de casos utilizaram novidades em seu trabalho pedagógico. Entretanto, não houve, de forma efetiva, uma ação criativa, pois não foram observados os impactos dessas novidades para a aprendizagem e desenvolvimento dos estudantes com necessidades educacionais especiais. Alguns aspectos que pautaram a identificação da criatividade no trabalho pedagógico foram: a promoção de novidades com valor para a aprendizagem e desenvolvimento dos estudantes, conforme defende Mitjáns Martínez (2008a).

O estudo de Cores (2004) indica que a criatividade no trabalho pedagógico não é sinônimo de novidade, de fazer "diferente". Ao contrário, revela-se na modificação sistêmica 
de diferentes elementos que compõe a prática educativa e que oferecem a aprendizagem e desenvolvimento dos estudantes, como destaca Mitjáns Martínez (2008a). Nessa perspectiva, dentre as possibilidades de estudo do tema, concordamos com citada autora: há uma forte tendência de analisar a criatividade no trabalho pedagógico do professor a partir do que ele faz de novo, sem considerar o critério de valor para a aprendizagem dos estudantes.

A propósito, chamamos a atenção para o fato de que há poucos estudos a respeito do tema, o que pode ser caracterizado como um fator que dificulta a organização de ações reais e efetivas para a promoção de situações favoráveis à mobilização da criatividade do professor, com vistas à realização de práticas novas e com valor para a aprendizagem e desenvolvimento dos estudantes. Isso repercute, por sua vez, tanto nas discussões a respeito da formação docente inicial e em serviço, como no cotidiano escolar e nas relações entre os segmentos que o compõe, pais, estudantes, professores, direção, comunidade.

A nossa pesquisa buscou contribuir teoricamente para a área, procurando compreender processos subjetivos que configuram a criatividade no trabalho pedagógico do professor e, mais, as suas inter-relações com o movimento em sua subjetividade. Tivemos em vista, portanto, o professor como profissional criativo, que no decorrer de sua história de vida e de suas experiências históricas, pessoais e docentes desenvolveu recursos subjetivos que participam de sua criatividade no trabalho pedagógico. E que, no cotidiano educativo, tem a possibilidade de aprender e se desenvolver a partir do contexto social e cultural de que participa, das relações sociais e com a realização de suas práticas educativas.

Essa perspectiva, que parte do professor em contexto, pauta-se na compreensão de que a criatividade é um processo complexo da subjetividade humana na simultânea condição da subjetividade social e a subjetividade individual, como define Mitjáns Martínez (2004, 2008a). Assim, para compreender essa abordagem acerca da criatividade, torna-se relevante nos aproximarmos antes da Teoria da Subjetividade na perspectiva Histórico-Cultural, elaborada por González Rey, a qual fundamenta as colocações da citada autora a respeito da expressão criativa. 


\section{A TEORIA DA SUBJETIVIDADE NA PERSPECTIVA HISTÓRICO- CULTURAL E A CRIATIVIDADE NO TRABALHO PEDAGÓGICO DO PROFESSOR}

Neste capítulo apresentaremos as bases teóricas desta pesquisa: a Teoria da Subjetividade na perspectiva Histórico-Cultural em suas categorias principais, e o que compreende movimento, impactos, mudanças e desenvolvimento da subjetividade. Em seguida, abordaremos a criatividade no trabalho pedagógico do professor, os significados para o professor e para a prática educativa.

\subsection{Aproximações à Teoria da Subjetividade na perspectiva Histórico-Cultural}

A Teoria da Subjetividade na perspectiva Histórico-Cultural desenvolvida por González Rey sofreu influências do percurso acadêmico do autor, que partiu do estudo da personalidade e da psicologia social para a proposição de sua visão específica e qualitativamente distinta da psique humana. Nesse processo, segundo o próprio González Rey (2005a), repercutiram em sua trajetória suas leituras acerca dos humanistas norte-americanos, sobre Freud e Allport, sobre os escritos de Bozhovich e seus colaboradores e o seu trabalho de doutorado sob orientação de Chudnovsky no laboratório do Instituto de Psicologia Geral e Pedagógica de Moscou, bem como sua crítica à Teoria da Atividade de A. N. Leontiev.

Aliadas a essas influências, Mitjáns Martínez (2005) ressalta que a Teoria da Subjetividade de González Rey constitui expressão do paradigma da complexidade da psicologia e tem sua gênese no pensamento dialético, nas construções do citado autor a partir do enfoque Histórico-Cultural do psiquismo humano, fundamentalmente de Vigotski e Rubinstein.

São esses aspectos que, em conjunto, nos permitem aproximarmos da maneira como González Rey compreende as articulações entre o social e o individual, como visualiza o caráter histórico e atual dos processos subjetivos, assim como as relações entre os processos simbólicos e emocionais na constituição das pessoas e dos espaços sociais. No nosso entendimento, essas três articulações perpassam as categorias que compõem o arcabouço teórico da Teoria da Subjetividade e proporcionam um olhar diferenciado acerca das experiências humanas, da forma como elas são vivenciadas e dos processos que engendram o desenvolvimento dos indivíduos em áreas distintas de sua vida. 
Essas articulações evidenciam-se na maneira como González Rey (1999, 2003, 2005b, 2011a, 2011b) apresenta a subjetividade, como um sistema complexo produzido de forma simultânea no nível social e individual, que representa a organização de processos simbólicos em sua unidade inseparável com as emoções, que emergem e se organizam de maneiras diferenciadas e em níveis diferentes nos indivíduos e na personalidade, e em espaços sociais onde as pessoas estão inseridas.

Nessa perspectiva, tem-se a simultânea relação entre a subjetividade individual e a subjetividade social. Essa última é definida como a organização subjetiva dos diversos espaços sociais, que formam sistemas configurados pela multiplicidade de processos simbólicos e emocionais produzidos por indivíduos nos distintos contextos sociais onde atuam. Refere-se aos sistemas complexos de produção subjetiva comprometida com os novos campos de subjetivação que surgem na ação social, expressando-se por um fluxo permanente de ações e processos que têm lugar nos diferentes espaços sociais da atividade humana. Constitui-se por crenças, mitos, representações, discursos, tradições, ritos, padrões de relações que se articulam no funcionamento social, nas práticas sociais e em suas diversas formas de institucionalização. Nesse sistema integram-se as produções de sentidos que são ao mesmo tempo históricas e atuais, procedentes de diferentes espaços sociais, constituindo verdadeiras tramas sociais (GONZÁLEZ REY, 2002, 2005b, 2007b, 2011a, 2011b).

Nesses espaços sociais encontram-se as instituições educativas, nas quais se constituem subjetividades sociais distintas, em inter-relação com as pessoas que integram a dinâmica educativa, e com as experiências históricas e culturais experimentadas naqueles espaços. Dessa maneira, as ações educativas, o trabalho pedagógico desenvolvido, está relacionado à subjetividade social da instituição educativa em particular. A propósito, Mitjáns Martínez (2008a, p. 78) esclarece que na subjetividade social do espaço escolar participam diferentes aspectos: “[...] o clima emocional, as formas de relação, o sistema de crenças e valores em relação ao ensinar, ao aprender, ao aluno e ao trabalho pedagógico [...], o significado dado à criatividade e muitos outros aspectos.”. Em cada configuração subjetiva de um espaço social estão, portanto, elementos de sentido advindos de outros, bem como elementos que caracterizam esse próprio cenário em momentos históricos antecedentes. Dessa forma, a configuração subjetiva de certo espaço permite a visibilidade de outros, com os quais interage (GONZÁLEZ REY, 2003).

A subjetividade social, por sua constituição, em termos de princípios e normas, pode limitar ou instigar a expressão das pessoas, que, respectivamente, se subordinam a elas ou se 
tornam sujeitos de sua atividade, produzindo alternativas que definem uma tensão permanente entre sua produção e o que é socialmente reconhecido. Isso indica o compromisso permanente e contraditório entre a subjetividade social e a subjetividade individual, que se mostram não como relações imediatas, mas como momentos, com relativa independência, que se contradizem e promovem tensão entre si (GONZÁLEZ REY, 2007b, 2011a).

Essa tensão é compreensível pela forma como González Rey $(1995,2003)$ enfatiza a atuação dos indivíduos e da sociedade, que se definem na qualidade de constituintes e constituídos um do outro. Nesse processo permanente, configura-se a condição de sujeito e a personalidade, que sem ser a mesma coisa, integram o sistema da subjetividade individual. Esta, para o autor, é dialógica, dialética e complexa, organiza-se por meio e concomitantemente às subjetividades sociais, tendo sua gênese nos espaços históricos, culturais e sociais que antecedem o sujeito psicológico. Os processos da subjetividade individual são, assim, momentos da subjetividade social, momentos que se constituem de maneira recíproca, sem que um se dilua no outro, sendo possível seu entendimento somente na condição de processo permanente (GONZÁLEZ REY, 2003).

Nessa direção, percebe-se que a subjetividade individual se constitui de maneira singular e irrepetível, por meio das relações pessoais que se estabelecem no curso das experiências do indivíduo, construindo uma rota única e diferenciada (GONZÁLEZ REY, 2003). Isso é enfatizado pelo caráter histórico e processual, que integra a condição de sujeito. Categoria que enfatiza o caráter gerador da pessoa, a sua possibilidade de reflexão e o seu posicionamento ativo diante das diversas situações vivenciadas.

Para Mitjáns Martínez (2000), a categoria sujeito evidencia a participação do professor em sua expressão criativa, compreendendo ainda como sujeito psicológico aquele que atua, faz escolhas, constrói representações da realidade e vivencia diversas emoções em seus processos interativos nos contextos em que se insere.

Sujeito que é caracterizado por ser consciente, pela atividade pensante, por uma intencionalidade, atreladas ao contexto ideológico, relacional e histórico de que participa o indivíduo. Nessa perspectiva, o sujeito é dialógico e emocional, revela-se nos momentos de tensão, ruptura, mudanças, criação, no comprometimento, na produção de espaços sociais singulares, na defesa de um ponto de vista e no lugar que assume em uma ação (GONZÁLEZ REY, 2003, 2004b, 2007b, 2011a).

Por isso, não se trata de uma condição estática ou universal, ao contrário, é processual; a pessoa atua como sujeito pelo modo como está envolvida em uma atividade, pela maneira 
como é capaz de abrir espaços próprios, específicos. Isso implica o entendimento de que o sujeito é constituído por suas condições, ao mesmo tempo em que é constituinte dessas condições. E, indica sua alta mobilidade psicológica, fruto dos processos subjetivos que se formam no curso de suas experiências e dos novos espaços de subjetivação que são produzidos, processos por meio dos quais produz sentidos subjetivos que permitem a criação de novas alternativas perante as experiências vividas (GONZÁLEZ REY, 2003, 2004b, 2007b, 2011a).

Essas alternativas estão atreladas ao que González Rey define como sentido subjetivo, categoria marcante de sua proposta teórica e que avança e se diferencia do construto de sentido de Vigotski. Na Teoria da Subjetividade, os sentidos subjetivos se constituem como uma nova síntese advinda dos processos simbólicos e emocionais que emergem no curso de uma experiência vivida ${ }^{3}$, sem que um seja diluído ou reduzido ao outro. Isso envolve a relação entre as emoções e os processos simbólicos em um movimento permanente, fluido e processual, associados a um momento atual, a experiência, sendo não intencional para a pessoa.

Trata-se, portanto, da produção subjetiva produzida dentro de redes de eventos, de práticas culturais, por meio de processos históricos de relação. Por isso, os sentidos subjetivos são caracterizados pela plasticidade, por vínculos contraditórios, mas autênticos. Podem emergir nas diferentes atividades humanas e são os responsáveis pela conotação subjetiva dessas atividades, integrando-se momentos e experiências anteriores ao contexto atual. Isso faz com que os sentidos subjetivos gerados em uma esfera da vida apareçam de forma ativa em outra, afetando recursivamente a própria experiência atual. Articulam-se, assim, às cadeias simbólico-emocionais que se organizam em configurações subjetivas da experiência atual em andamento, da mesma forma que os sentidos subjetivos são o resultado da configuração subjetiva que se organiza em torno da experiência vivida (GONZÁLEZ REY, 2003, 2004b, 2007b, 2011a, 2011b, 2012).

Essas cadeias simbólico-emocionais constituem as configurações subjetivas, as quais, para González Rey (2002), representam formações psicológicas complexas, caracterizadoras das formas mais estáveis de organização social e individual dos sentidos subjetivos, que podem se constituir no momento processual de uma atividade ou experiência. Nas palavras do autor, elas são “[...] as verdadeiras unidades da subjetividade humana, pois representam os

\footnotetext{
${ }^{3}$ Esclarecemos que a expressão "experiência vivida" utilizada neste trabalho refere-se às situações em que há uma produção subjetiva.
} 
momentos de convergência e articulação da mobilidade dos sentidos subjetivos que emergem na ação." (GONZÁLEZ REY, 2011b, p. 34).

A emergência e constituição de sentidos subjetivos e configurações subjetivas no curso da ação, como aponta o autor, indicam que o professor que expressa criatividade no trabalho pedagógico pode se "alimentar" dos processos subjetivos que se formam durante as práticas pedagógicas criativas. Processos que evidenciam a articulação das diferentes experiências vividas pelo docente, sua historicidade, sua trajetória profissional e de vida e as diferentes maneiras como que podem ser subjetivadas.

Isso porque as configurações subjetivas envolvem a unidade do histórico e do atual na organização subjetiva, representando a expressão do vivido como produção subjetiva, uma verdadeira rede simbólico-emocional em processo que integra os diversos efeitos e desdobramentos do que foi vivenciado. Delas participam sentidos subjetivos procedentes de diferentes situações e experiências muito diferentes da pessoa, os quais no momento atual adquirem a capacidade geradora de sentidos subjetivos específicos. Não seguem, portanto, a nenhuma lógica racional; ao contrário, são processos com múltiplas opções de desenvolvimento, suscetíveis de crises inesperadas. São singulares, organizações únicas (GONZÁLEZ REY, 2002, 2011a, 2011b).

Reconhecemos, assim, a complexidade do estudo e construção das configurações subjetivas. Por isso, no processo construtivo-interpretativo de nossa pesquisa, optamos por núcleos subjetivos, considerando que eles abarcam um conjunto de sentidos subjetivos e diversos processos de subjetivação, produções subjetivas que nos possibilitam o estudo da subjetividade individual de professores que expressam criatividade no trabalho pedagógico.

Para além destas considerações, compreendemos que as configurações subjetivas, na sua variabilidade de aspectos mais estáveis, nos permite aproximarmos do entendimento proposto por González Rey $(2007$ a, 2012) a respeito da personalidade, a qual para ele está relacionada a uma definição configuracional associada a cada momento da experiência vivida. Refere-se, então, à organização subjetiva das experiências vividas, constituindo um sistema de "[...] configurações subjetivas em desenvolvimento permanente, dentro do qual uma configuração pode, sob determinadas condições, se converter em um sentido subjetivo de outra.” (GONZÁLEZ REY, 2007a, p. 172).

Para González Rey (1995, p. 59), a personalidade diz respeito a uma "configuração de configurações", o que se distancia da somatória de traços e de uma organização estática que se expressa nas condutas ou que conduz uma ação. Segundo o autor, a personalidade se 
atualiza a partir dos processos subjetivos que emergem no curso das atividades e ações desenvolvidas pelas pessoas. Por isso, tem caráter vivo e dinâmico, o que abrange um processo constante de configuração e reconfiguração subjetiva (GONZÁLEZ REY; MITJÁNS MARTÍNEZ, 1989; GONZÁLEZ REY, 2011a).

Esse movimento que integra a caracterização da personalidade em suas configurações subjetivas indica a possibilidade de desenvolvimento subjetivo e o papel das relações sociais e das experiências vividas para engendrar os processos de (re) configuração subjetiva. Pautadas nessa compreensão, aproximamo-nos do movimento, impactos, mudanças e desenvolvimento subjetivo, de acordo com o arcabouço teórico da Teoria da Subjetividade na perspectiva Histórico-Cultural de González Rey.

2.1.1 Movimento, impacto, mudanças e desenvolvimento da subjetividade

A compreensão das categorias que compõem o sistema subjetivo, segundo a Teoria da Subjetividade de González Rey, evidencia que o movimento é inerente aos processos da subjetividade humana. Movimento este marcado pela permanente produção de sentidos subjetivos que se atualizam no curso das diferentes experiências vividas, que podem engendrar os processos de configuração e reconfiguração subjetiva, a condição de sujeito e a constituição dos recursos subjetivos que integram as diferentes ações realizadas. Para González Rey (2007b) prevalece a ideia de devir, de movimento que o sistema está recebendo, permanentemente, influências de outros sistemas e produzindo novas opções frente a essas influências. Em suas palavras vemos que (GONZÁLEZ REY, 2011b, p. 84):

[...] a ideia de configuração subjetiva nos permite gerar inteligibilidade sobre um sistema subjetivo em movimento ao qual só conseguimos acessar de forma progressiva na medida em que a pessoa vai se adentrando nas suas reflexões e considerações, que por sua vez constituem fontes de informações sobre os processos e sentidos subjetivos que de forma permanente são produzidos nessas configurações sobre as quais a própria pessoa não tem nem pode ter uma representação consciente.

Na pesquisa partimos dessa premissa de movimento contínuo dos processos subjetivos, mas tivemos o interesse de nos aproximar das inter-relações entre a expressão criativa no trabalho pedagógico e suas possíveis articulações com essa mobilidade da subjetividade individual do professor, os processos e as mudanças subjetivas, compreendendo, assim, de que forma as experiências e situações geradas nas práticas pedagógicas criativas proporcionam ao professor novos espaços de subjetivação, a constituição e o exercício da condição de sujeito em seu campo profissional e os processos de produção subjetiva. 
Construímos, com isso, nossa interpretação acerca dos processos subjetivos que participam da expressão criativa do professor no trabalho pedagógico, considerando aqueles que integram essa criatividade, e, avançando nas especificidades e na articulação dos três elementos que Mitjáns Martínez (2008a) apontou: a necessária condição de sujeito do professor, a configuração de sua subjetividade individual e da subjetividade social de que participa.

Partimos da ideia de que o exercício da prática pedagógica criativa pode favorecer esse processo permanente de movimentos na subjetividade, proporcionando experiências que possibilitam impactos na subjetividade do professor. Tais impactos são vistos como os processos de subjetivação que emergem das relações sociais e das experiências vivenciadas pelos indivíduos, os quais viabilizam a produção de novos sentidos subjetivos (GONZÁLEZ REY, 2004a). São inseparáveis tanto do contexto da subjetividade social em que o acontecimento se produz, como dos recursos subjetivos que a pessoa possui (GONZÁLEZ REY, 2005a). E não implicam necessariamente processos de mudanças subjetivas ou de desenvolvimento da subjetividade individual.

Isso porque as mudanças subjetivas são compreendidas conforme pontua Geandra Santos (2010): como a produção de novos sentidos subjetivos que resultam na constituição de outros repertórios subjetivos, o que pode ocorrer em diferentes níveis. Pautada na Teoria de Subjetividade na perspectiva Histórico-Cultural, a autora afirmou:

[...] de acordo com o tipo de movimentação desencadeada na subjetividade individual, pode-se produzir diferentes níveis ou qualidades de mudanças, capazes até de inaugurar novas produções de sentidos subjetivos que transformem o próprio sistema em vigor (SANTOS, G., 2010, p. 55).

Essas transformações caracterizam o que Geandra Santos (2010) denominou como mudanças não significativas, pouco significativas, ou significativas. Nas mudanças não significativas o impacto de determinadas situações promovem uma movimentação coerente com os processos subjetivos existentes em certa configuração subjetiva implicada no momento, o que é evidenciado pelos processos de consolidação dos sentidos subjetivos dominantes naquela configuração, e que gera um novo repertório emocional. Entretanto, não se produz uma organização subjetiva alternativa.

Nas mudanças pouco significativas, Geandra Santos (2010) verificou que os impactos viabilizam uma movimentação subjetiva sem caráter expressivo e sem a estabilidade requerida para atuarem como elementos centrais de uma configuração subjetiva específica, o 
que se mostra por meio de consolidações e modificações restritas nos sentidos subjetivos da configuração subjetiva implicada no momento da situação vivenciada.

Por outro lado, os impactos subjetivos podem favorecer mudanças significativas, entendidas como uma movimentação expressiva e com certa estabilidade, que se expressam por meio da produção alternativa e emergência de sentidos subjetivos responsáveis pelo processo de reorganização da configuração subjetiva implicada na mudança (SANTOS, G., 2010).

Assim, nas inter-relações entre o trabalho pedagógico e os processos subjetivos do professor, Geandra Santos (2010) afirma que as mudanças na subjetividade individual do docente solicitam uma produção alternativa de sentidos subjetivos favoráveis à relação e responsabilização com os estudantes, tornando-se significativa somente se for constituída por uma organização subjetiva com capacidade generativa e pelo exercício da condição de sujeito de forma expressiva. Esses aspectos, em nosso ponto vista, podem ser gerados no cotidiano do trabalho pedagógico criativo, que pode favorecer situações desde impactos a desenvolvimento subjetivo.

Além disso, consideramos que essas mudanças significativas que a citada autora apresenta aproximam-se do que Rossato (2009, p. 180) concluiu acerca do desenvolvimento subjetivo. Para ela, trata-se de "[...] mudanças subjetivas que ganham certa estabilidade, originando outras mudanças, gerando novos níveis qualitativos de organização subjetiva.”. Nesse processo de desenvolvimento, a pesquisadora destaca dois aspectos: a) constituição da condição de sujeito no confronto com o outro e b) mudança na personalidade gerada pelos processos de reconfigurações subjetivas e pela produção de novos sentidos subjetivos.

Ao ressaltar esses dois aspectos, Rossato (2009) converge para o que González Rey (2004b) afirma a respeito do desenvolvimento da subjetividade: é um processo integral que ocorre em torno de sistemas de sentidos subjetivos, pela produção desses sentidos que influenciam fortemente a personalidade, e não como um conjunto fragmentado de aquisições. Nessa direção, o desenvolvimento compromete, de maneira simultânea, diferentes formações da personalidade em configurações de sentidos subjetivos que remetem ao crescimento da pessoa em variadas esferas de sua vida (GONZÁLEZ REY, 2004b).

Para o autor, o desenvolvimento subjetivo acontece por meio da constituição de unidades de sentidos subjetivos, o que abrange a forma de organização dos significados e dos sentidos subjetivos que caracterizam a constituição dos processos psíquicos. Essas unidades são capazes de implicar aspectos psicológicos diferentes em um indivíduo concreto, o que não 
corresponde a etapas universais, mas sim a momentos, experiências reais da vida da pessoa (GONZÁLEZ REY, 2000, 2004b). Para ele:

\begin{abstract}
Percebemos o desenvolvimento tanto na possibilidade de gerar novos repertórios de expressão de uma configuração subjetiva, que podem representar momentos de novos sentidos subjetivos que se integram a essa configuração, como nos momentos de reorganização e ruptura de certos sistemas de configurações subjetivas em face da emergência de outros novos (GONZÁLEZ REY, 2007b, p. 138).
\end{abstract}

Disso decorre o fato de que o desenvolvimento da subjetividade envolve de forma concreta o contexto atual, cultural, social e relacional no qual o indivíduo está inserido. Nessa direção, segundo González Rey (2004b), cada situação vivida é subjetivada de maneira singular, pois nela participam sentidos subjetivos constituídos na ação, que estão também constituídos por outros sentidos subjetivos produzidos ao longo de sua história.

Desse modo, os processos de subjetivação não estão definidos pela produção subjetiva inicial, e sim pelo desenvolvimento diferenciado das pessoas no curso da atividade que realizam (GONZÁLEZ REY, 2007b). Nessa produção subjetiva há uma tensão constante entre os novos sentidos subjetivos que emergem na ação e as configurações subjetivas dominantes que caracterizaram o início dessas ações, o que expressa uma das tensões importantes para o desenvolvimento da personalidade e dos espaços sociais (GONZÁLEZ REY, 2011a).

Essa rede subjetiva que se constitui no curso de uma experiência ou ação é inacessível à intencionalidade consciente do indivíduo. Os sentidos subjetivos enfatizam o papel gerador das emoções, as quais não se subordinam a uma mediação de significados, ao contrário, as emoções se constituem como uma forma de expressão da pessoa diante do momento vivido (GONZÁLEZ REY, 2004b, 2007b).

Essas emoções articulam-se, no nosso ponto de vista, às relações sociais, no que concordamos com Tacca (2006), quando ela afirma que essas relações projetam a força de motivos e necessidades dos indivíduos, o que envolve a unidade cognição e afeto e o papel das experiências pessoais como integradoras dos processos de desenvolvimento. Nessa perspectiva, González Rey (1995) esclarece que, em uma relação interpessoal em que a pessoa realmente se implica, ela coloca em tensão todos os seus recursos, mantendo uma orientação intencional para a relação que lhe permite assumir seus motivos de uma maneira pensante e intencional, determinando a possibilidade de mudanças bruscas e profundas, algumas das quais podem gerar desenvolvimento.

Além disso, Tacca (2004, p. 105) esclarece que o outro social e o meio social não servem apenas para comunicar mensagens que favoreçam a construção da identidade pessoal, 
mas que isso envolve um processo complexo de "[...] troca e participação ativa no convívio social que gera e integra os processos de desenvolvimento que se fazem presentes na 'constituição subjetiva' de cada um dos atores sociais.".

Para a citada autora, se na sala de aula vivencia-se a dinâmica das relações sociais, não há alternativa senão considerá-la como espaço onde confluem pessoas que, na trama interativa, trazem diferentes motivações, significados e sentidos que atuam em interinfluências, o que torna o contexto escolar um espaço de desenvolvimento da subjetividade (TACCA, 2006).

Nas relações que se formam nesse contexto e em outros, pode se configurar o outro social como um outro significativo para o desenvolvimento, em que ele adquire essa qualidade apenas quando a pessoa consegue um relacionamento com esse outro marcado pela produção de sentidos, de maneira que, se o vínculo de sentidos subjetivos não se estabelece, esse outro não será uma figura significativa para o desenvolvimento (GONZÁLEZ REY, 2004b).

Ter em vista o papel do outro e das relações sociais no desenvolvimento subjetivo, supõe retomar o que González Rey (1995) denominou como forças motrizes do desenvolvimento da personalidade. Naquele momento, década de 1990, o autor enfatizou três elementos dinamizadores: a comunicação e o ambiente social; as contradições; e as unidades subjetivas de desenvolvimento.

Por unidades subjetivas do desenvolvimento o autor se refere às atividades ou relações da pessoa que comprometem seus recursos potenciais em um momento, configurando-se de modo estável a nível subjetivo e formando um verdadeiro sistema dinâmico de relações essenciais entre seus diversos elementos. A esse respeito, ele esclarece que toda relação ou atividade estável que o indivíduo realiza se expressa em uma configuração subjetiva. Entretanto, somente aquelas configurações que estimulam a constituição de elementos ou formações suscetíveis de desenvolvimento em um momento específico desse processo formam unidades subjetivas de desenvolvimento.

Para tanto, faz-se necessário que a pessoa tenha uma verdadeira motivação a respeito dessa atividade ou relação, sendo relevante que haja alto nível de individualização, expresso em sua iniciativa, criatividade e autenticidade. É interessante ressaltar a possibilidade de existência de variadas unidades subjetivas de desenvolvimento, as quais nem sempre serão conscientes para a pessoa. Além disso, a temporalidade de cada uma delas será distinta, diferenciando-se ao longo da vida do indivíduo (GONZÁLEZ REY, 1995). 
Esse tempo relativo das unidades subjetivas de desenvolvimento está relacionado, ainda, à compreensão do que são as configurações subjetivas, compreendidas em seu caráter móvel, flexível e passível de mudanças no curso das diferentes experiências vividas. Essa categoria integra a definição de González Rey (2004b, p. 18) a respeito do que são essas unidades. Ele afirma:

O que definimos como unidades subjetivas do desenvolvimento são, na realidade, configurações subjetivas com a capacidade de integrar e estimular um conjunto de aquisições do desenvolvimento em determinados momentos da vida da pessoa. Há configurações subjetivas que mantêm esse papel no desenvolvimento por períodos muito prolongados [...]. Mas, há outras, cujas possibilidades são dadas por períodos sensíveis que se relacionam com um determinado momento da vida do sujeito [...]. (Grifo nosso).

Dessas nuances da temporalidade julgamos que participam, também, o que o autor chamou de contradições, as quais se referem às situações específicas que comprometem a pessoa com uma resposta, o que pode colocá-la diante de uma situação social qualitativamente diferente, em que entrem em jogo novos recursos que deem lugar a uma mudança estável em suas configurações subjetivas (GONZÁLEZ REY, 1995).

Essas contradições, segundo González Rey (1995), podem ser conscientes para o indivíduo, implicando de maneira clara sua intencionalidade; e, outras, expressam-se em experiências cuja natureza, muitas vezes, ele não compreende. Ademais, podem se configurar tanto como favoráveis ao desenvolvimento, representando a possibilidade de um novo momento qualitativo, como em danos, por meio de experiências negativas. Isso decorre do fato de que as contradições não representam ações pontuais de enfrentamento, são verdadeiros processos ao longo das quais pode se desenvolver mudanças significativas.

Nesse percurso, integram-se o ambiente social e a comunicação, em que o social encontra sua significação para o desenvolvimento, tanto em seus aspectos mais gerais, como o clima social geral e os diferentes climas institucionais, como nas relações que se personalizam mediante os processos de comunicação interpessoal. É em meio aos distintos ambientes sociais que se definem as experiências que são essenciais para o bem- estar emocional da pessoa, como segurança, confiança, ordem, dentre outros. São experiências que podem produzir uma multiplicidade de vias de atuação do indivíduo (GONZÁLEZ REY, 1995).

Essas atuações são constituídas, em muitos momentos, por meio dos processos comunicativos que se estabelecem nos espaços sociais, o que, conforme González Rey (1995), podem se tornar tanto a extensão da individualidade da pessoa como uma restrição e inibição a sua ação. Para o autor, a comunicação será uma força motriz para o desenvolvimento quando o indivíduo está implicado ativamente no processo comunicativo e quando permite a 
constituição de novos aspectos que estimulam e atualizam os processos de configurações subjetivas e a formação de recursos subjetivos que inauguram níveis qualitativamente diferentes do desenvolvimento.

$\mathrm{Na}$ pesquisa realizada, consideramos as forças motrizes a que se refere González Rey (1995), as quais relacionamos à expressão criativa no trabalho pedagógico e os movimentos na subjetividade do professor. No processo construtivo-interpretativo, consideramos, ainda, os princípios fundamentais que Amaral (2011) destacou acerca de sua interpretação sobre o desenvolvimento da subjetividade segundo González Rey.

Para ela, existem cinco princípios que norteiam a construção do autor a respeito do desenvolvimento, quais sejam:

a) a perspectiva dinâmica do desenvolvimento da subjetividade que marca a dimensão irregular e descontínua desse processo;

b) lugar outorgado ao indivíduo no seu processo de desenvolvimento, o qual reage, transformando-se e operando transformações na sua interação com o mundo;

c) perspectiva integradora que possibilita visualizar as diversas dimensões que abrangem o processo de desenvolvimento da subjetividade;

d) o caráter recursivo e contraditório do desenvolvimento da subjetividade, estabelecendo-se uma relação recursiva entre as duas dimensões da subjetividade individual: a personalidade e o sujeito;

e) a importância das relações sociais que configuram o cotidiano do indivíduo no processo de desenvolvimento da subjetividade.

Os princípios destacados por Amaral (2011) foram, de certa maneira, abordados nas discussões apresentadas anteriormente, e nos levam a ressaltar que o desenvolvimento da subjetividade está em posição contrária às tendências de padronização ou homogeneização. A imprevisibilidade dos processos subjetivos e das diferentes formas de subjetivação das experiências humanas coloca em evidência a singularidade e as especificidades que constituem as subjetividades individuais e as próprias distinções que caracterizam as subjetividades sociais.

Pensar nessa multiplicidade de alternativas para os processos de (re) configuração subjetiva, que são marcadamente contínuos, coloca em destaque, também, a participação dos diversos espaços sociais e relacionais para o desenvolvimento da subjetividade. Aspecto esse que se relaciona ao interesse particular de nossa pesquisa, que investigou esses processos de 
movimentos subjetivos e suas inter-relações com a criatividade no trabalho pedagógico do professor.

Assim, nos fundamentamos nessa mobilidade inerente aos processos subjetivos, movimento que envolve tanto o desenvolvimento de recursos subjetivos que favoreçam a condição de sujeito do professor, como a constituição contínua dos processos de mudanças. Pautadas nessa compreensão e nos demais aportes teóricos da Teoria da Subjetividade na perspectiva Histórico-Cultural, apresentamos a seguir o que compreendemos em relação à criatividade no trabalho pedagógico.

\subsection{A criatividade no trabalho pedagógico: os significados para o professor e para a prática educativa}

Neste tópico nos aproximamos da compreensão da criatividade como processo complexo da subjetividade humana, tendo em vista os aspectos apresentados, anteriormente, a respeito das categorias teóricas que compõem a Teoria da Subjetividade na perspectiva Histórico-Cultural de González Rey. Em seguida, apresentamos o que entendemos a respeito da criatividade no trabalho pedagógico e os seus elementos constitutivos.

\subsubsection{A criatividade como processo complexo da subjetividade humana}

A criatividade se configura como objeto de estudo de diferentes áreas do conhecimento, como a Psicologia e a Filosofia. Estas tiveram maiores repercussões na compreensão da expressão criativa no campo da educação (NEVES-PEREIRA, 2004). Nesses estudos, encontram-se diversos conceitos para o termo, mais de quatrocentos, segundo Mitjáns Martínez (2003a). São conceitos que revelam características, critérios e abordagens variadas para compreensão dos processos criativos.

Apesar de reconhecermos a relevância das diversas abordagens a respeito do tema, fizemos a opção pelo aporte teórico que compreende a criatividade como processo complexo da subjetividade humana, que considera a simultânea condição da subjetividade individual e subjetividade social, conforme define Mitjáns Martínez (2004, 2008a). Nessa perspectiva teórica, integram-se dois aspectos centrais, os quais justificam sua escolha, que são a consideração do sujeito e sua subjetividade individual e as inter-relações com a subjetividade social dos diferentes espaços sociais de que participa o professor. Essa perspectiva rompe, 
assim, com as dicotomias presentes em diversas concepções de criatividade que ora a definem como processo individual, ora como processo social.

Fundamentada em reflexões críticas e reflexivas a respeito da perspectiva históricocultural e de pesquisas com profissionais criativos, a autora enfatiza a complexidade e as múltiplas confluências para o desenvolvimento da criatividade. Dentre essas, destacamos inicialmente a condição de sujeito que se faz presente na expressão criativa, categoria que, de acordo com Mitjáns Martínez (2004), aponta para o aspecto interativo e conjuntural da subjetividade.

Nos processos criativos, a autora supracitada considera que é o indivíduo quem se relaciona com os outros nos contextos sociais em que participa, é ele que toma decisões, vivencia emoções e constrói representações da realidade (MITJÁNS MARTÍNEZ, 2004). O professor, na sua condição de sujeito, faz representações do espaço escolar que perpassam a organização do trabalho pedagógico e a sua ação docente, resolve conflitos, planeja e desenvolve a prática educativa. Nessas experiências pedagógicas, experimenta emoções diversas, as quais podem gerar sentidos subjetivos que emergem na ação e participam, de alguma forma, da sua prática criativa (MITJÁNS MARTÍNEZ, 2008a).

Além disso, partimos do princípio de que a criatividade no trabalho pedagógico possui um caráter subversivo, como coloca Mitjáns Martínez (2008a). Implica situações de enfrentamento e posicionamento próprio do professor, que rompe com situações pedagógicas "tradicionais" e propõe ações educativas que inauguram novidades valiosas para a aprendizagem e desenvolvimento dos estudantes.

Para isso, torna-se importante ter em conta os recursos subjetivos favoráveis à condição de sujeito do professor, o qual, por meio de sua prática profissional e das relações sociais que se constituíram ao longo de sua experiência, pode desenvolver a possibilidade de autodeterminação pessoal e profissional, traçando objetivos próprios em sua prática pedagógica e, com isso, exercendo sua condição de sujeito no trabalho pedagógico.

Nessa perspectiva, faz-se relevante considerar os processos de produção de sentidos subjetivos relacionados ao trabalho pedagógico, e mais, as configurações subjetivas que participam da ação e da expressão criativa nas práticas educativas. Isto é, a criatividade no trabalho pedagógico está vinculada à subjetividade individual do professor, no que se refere ao necessário exercício da condição de sujeito e a mobilização das configurações subjetivas de sua personalidade. 
A propósito, tínhamos em vista que há certa recursividade quando as próprias práticas criativas viabilizam a produção de processos subjetivos que favorecem o movimento e um possível desenvolvimento da subjetividade do professor. Essas práticas proporcionam, por meio da intencionalidade expressa na produção de novidades com valor pedagógico, o redirecionamento de aspectos vinculados a sua autodeterminação profissional e pessoal e à organização de objetivos singulares e autônomos.

Assim, compreendemos que, concomitante à necessidade de desenvolvimento subjetivo por parte do docente, em especial de sua condição de sujeito, o trabalho pedagógico criativo pode gerar situações pedagógicas não previstas e planejadas que favorecem processos de mudanças subjetivas no professor, processos de constituição e reconstituição de suas configurações subjetivas, bem com o desenvolvimento de recursos subjetivos associados à sua prática docente e a criatividade.

Essas movimentações na subjetividade do professor no curso do trabalho pedagógico criativo conduzem à participação de suas configurações subjetivas na expressão criativa, conforme destaca Mitjáns Martínez (2008a). Para a citada autora, existem configurações subjetivas específicas vinculadas à criatividade, que denominou de configurações criativas (2003a, 2008a, 2008b, 2008c). Essas configurações representam articulações dinâmicas e altamente individualizadas de processos subjetivos que participam da expressão criativa.

Essas configurações criativas evidenciam que nem todos os elementos e configurações subjetivas que compõem a personalidade participam e influem nas práticas criativas (MITJÁNS MARTÍNEZ, 2003c, 2004). Em suas palavras a autora esclarece que utiliza:

[...] O conceito de configuração criativa para nos referirmos a integração dinâmica dos elementos personológicos que intervêm na expressão criativa do sujeito, ou seja, ao subconjunto de recursos da personalidade que possibilitam sua expressão criativa. (MITJÁNS MARTÍNEZ, 2003b, p. 175, tradução nossa).

Como afirma Mitjáns Martínez (2008a) essas configurações se constituem no percurso da história de vida da pessoa que expressa criatividade, e implicam considerar os processos subjetivos das mais diversas experiências do professor. Isso inclui, também, os processos de configuração e reconfiguração que ocorrem no curso da ação docente, na qual podem se constituir sentidos subjetivos diversos que integram os processos criativos no âmbito do trabalho pedagógico.

Em pesquisas com profissionais criativos, a autora identificou alguns elementos comuns às configurações criativas de indivíduos com alto grau de criatividade em sua atuação profissional, dentre eles professores. Foram: a) alto nível de desenvolvimento da motivação para a profissão; b) clara orientação de futuro no campo profissional; c) força da 
individualidade, tendo a autovaloração como elemento importante e dinâmico da criatividade; d) orientação muito ativa para a superação profissional; e) orientação consciente para a criação. Ela ressalta que esses elementos comuns não são os únicos das configurações criativas, ao contrário, o seu caráter altamente singular faz com que processos e sentidos subjetivos diversos constituam tais configurações (MITJÁNS MARTÍNEZ, 2003a, 2008a).

Dentre tais aspectos, Mitjáns Martínez (2008a) destaca o papel da motivação para a atividade de ensinar, de educar e suas articulações com e para a criatividade no trabalho pedagógico. Isso porque o professor, em muitas instituições educativas, trabalha em condições difíceis e desfavoráveis à introdução de práticas criativas, as quais requerem nessas situações alto grau de implicação e motivação profissional.

A esse respeito, esclarecemos que compreendemos a motivação como uma configuração subjetiva dinâmica que integra os motivos que se organizam de forma hierárquica de acordo com a própria constituição subjetiva do indivíduo e se atualizam no curso da ação empreendida (GONZÁLEZ REY, 1997, 2012). Na criatividade no trabalho pedagógico do professor, os motivos que impulsionam a atividade de educar podem se configurar no decorrer das práticas pedagógicas desenvolvidas, aliando-se a outros processos subjetivos.

Isso faz com que a motivação seja entendida como uma organização subjetiva de diferentes processos que fazem parte da ação, isto é, que se organizam no curso da ação, da atividade atual do indivíduo (GONZÁLEZ REY, 2012). González Rey (2012, p. 40) afirma que a motivação é uma formação complexa que integra o pensamento, as decisões, reflexões e produções da pessoa, o que conduz ao entendimento de que a motivação é uma "[...] articulação inseparável de sentidos subjetivos que estão para além da intencionalidade presente no sujeito.”. E mais, não se trata de um conteúdo pontual, interno, que define a priori o envolvimento da pessoa em certa atividade. Para o autor, a motivação é um tipo de configuração subjetiva que está na base da produção de sentidos subjetivos comprometidos com a ação na atividade concreta, define-se no sujeito e pelo sujeito, e não pelo tipo de atividade (GONZÁLEZ REY, 2005a).

Nessa perspectiva, consideramos que a criatividade no trabalho pedagógico do professor pode se constituir como uma tendência orientadora da personalidade, conforme define González Rey (1997). Para o autor, a tendência orientadora da personalidade contempla os motivos, que podem se converter em motivos dominantes na personalidade do indivíduo. Esses motivos se constituem em configurações subjetivas dinâmicas que se organizam em torno de um motivo central, de caráter intrínseco à atividade ou forma de relação, ao redor do 
qual se integram sentidos subjetivos diversos e outras necessidades advindas de diferentes momentos da vida da pessoa. Desse modo, há integração entre a motivação profissional e outros elementos procedentes de outras configurações subjetivas motivacionais que participam das configurações da personalidade (GONZÁLEZ REY, 1997).

Mitjáns Martínez (2003a) afirma que a atividade criativa é dinamizada por diferentes e complexos motivos, os quais se integram a intenções profissionais e a tendências orientadoras da personalidade. Nessas tendências evidenciam-se a elaboração consciente de projetos por parte da pessoa e o seu esforço na consecução de seus fins e propósitos, o envolvimento efetivo em certa atividade que lhe é significativa. Assim, os indivíduos são criativos justamente naquelas áreas em que se concentram suas principais tendências motivacionais, que constituem, por sua vez, formações motivacionais complexas. Em suas palavras (MITJÁNS MARTÍNEZ, 2003a, p. 61):

\footnotetext{
A criatividade nunca pode ser analisada à margem da hierarquia de motivos da personalidade; é precisamente sua análise em relação com a hierarquia motivacional da personalidade que nos pode explicar o porquê da conduta criativa em uma ou outra área da atividade do sujeito.
}

Essas formações motivacionais complexas incluem dois aspectos relevantes: as intenções profissionais, como um tipo específico de formação motivacional que se expressa em alto nível nos motivos para a atividade profissional; e a autovaloração, como expressão da unidade do cognitivo e afetivo que contempla a visão da pessoa sobre si mesma (MITJÁNS MARTÍNEZ, 2003a). Tais aspectos se modificam e atualizam no curso da atuação profissional, das relações que o professor estabelece com os integrantes do espaço escolar e das inter-relações entre sua subjetividade individual e a subjetividade social da instituição educativa, especialmente.

Nessa direção, evidencia-se também a participação do social para a constituição da criatividade no trabalho pedagógico, que se expressa no mínimo em duas dimensões: uma mais geral, configurada por normas, instituições, códigos morais e de relação, e os diferentes climas que dominam os espaços sociais em que o indivíduo se expressa. E, numa outra, a dimensão relacional, que envolve as relações com os outros e a participação dessa relação para a subjetividade individual e as configurações criativas (MITJÁNS MARTÍNEZ, 2004).

Considerar o social na constituição da criatividade envolve a compreensão do papel do outro para os processos subjetivos, tendo em vista que esse outro, como afirma González Rey (2004b), existe numa sequência histórica de uma relação que vai se transformando em um sistema de sentido, a partir do qual esse outro passa a ter significado no desenvolvimento psíquico, seja pela produção simbólica constituída no espaço da relação, seja pela produção de 
sentidos subjetivos. Para ele (GONZÁLEZ REY, 2004b, p. 8) o "[...] outro deve ser um outro portador de sentido subjetivo para atuar como figura significativa para o desenvolvimento", ainda que esse sentido possa se expressar tanto em favor do desenvolvimento, como do caráter patológico desse processo.

Mitjáns Martínez (2004) destaca que o indivíduo atua em contextos de relações com outros, que participam de diferentes formas da ação criativa e que estão presentes também na constituição dos sentidos subjetivos que participam da expressão da criatividade. É compreendido, assim, como um outro dialógico que, em sua condição de interlocutor ativo, integra a geração do espaço social em que se define a expressão criativa, podendo se tornar um incentivador de processos criativos, ou um estimulador do desenvolvimento de recursos subjetivos associados à criatividade.

Atrelada às colocações acima estão as afirmações de Tacca (2004, p. 102): “[...] é no contato com o outro social que vamos nos reconhecendo e nos constituindo como pessoa neste mundo", o que reforça a necessidade de se pensar no "sujeito em relação", expressão utilizada por ela. Para a autora, as pessoas interagem com os diferentes sistemas de relações do seu contexto e estão, de forma contínua, reconfigurando sua subjetividade (TACCA, 2005).

Nessa perspectiva das relações, e da constituição do professor, Cunha (2004, 2005) afirma que o professor aprende a sê-lo por meio do trabalho que realiza, e que esse trabalho articula, entre tantos elementos, os estudantes, o conhecimento e o contexto subjetivo da instituição educativa. Professores e estudantes constituem-se como tal na dinâmica das relações que se estabelecem no contexto da instituição e da sala de aula. Por isso, afirma que refletir acerca do ensino que o professor realiza possibilita compreender o processo que o constitui, o que leva a entender o aprendizado que esse profissional realiza do ponto de vista das relações subjetivas e sociais que ele mantém.

Isso conduz ao entendimento de que a criatividade no trabalho pedagógico do professor configura-se no espaço das relações sociais, no processo histórico e profissional do docente. Tal afirmativa está pautada na consideração de que, nos diferentes espaços sociais e educativos, podem se constituir demandas, necessidades educativas, desafios pedagógicos que, articulados à organização subjetiva do professor, favoreçam a produção de novidades com valor para a aprendizagem e desenvolvimento dos estudantes. Essas necessidades perpassam tanto o compromisso profissional, a intencionalidade pedagógica das escolhas 
docentes, como motivos históricos e atuais para a realização do trabalho docente e das demandas sociais vinculadas à educação.

Compreendemos, ainda, que os sistemas relacionais no contexto escolar podem gerar necessidades associadas aos recursos subjetivos vinculados à criatividade no trabalho pedagógico do professor. Isto é, a partir das relações históricas e as que se constituem no cotidiano da instituição, nos vínculos que se formam, o docente pode se envolver de maneira diferenciada com o processo de aprendizagem de seus alunos, o que, por sua vez, pode gerar uma série de sentidos subjetivos que se configuram como mobilizadores do desenvolvimento de recursos subjetivos presentes na expressão criativa do professor no trabalho pedagógico.

Assim, tivemos como ideia inicial que essas relações e os processos subjetivos nelas envolvidos podem favorecer processos simbólicos e emocionais que participam da criatividade no trabalho pedagógico do professor. Permitem, com isso, ao professor (e aos estudantes) ampliar suas oportunidades de movimentos subjetivos, o que implica diferentes tipos de mudanças em sua subjetividade individual e determinação de projetos e objetivos próprios por parte do professor.

Nessa direção, as situações cotidianas e as relações sociais que se constituem no espaço da instituição podem ter uma participação na expressão criativa no trabalho pedagógico. Tornam as relações construídas no espaço da instituição lócus tanto para o desenvolvimento da criatividade e de seus recursos subjetivos, como de movimentos na subjetividade do professor, em seus processos de configuração e reconfiguração subjetiva, bem como da condição de sujeito do professor no exercício de sua profissão.

Consideramos que as situações inesperadas e não planejadas que surgem no contexto da instituição educativa podem possibilitar a mobilização dos recursos subjetivos associados à criatividade no trabalho pedagógico do professor, o que pode ocorrer quando há a produção de sentidos subjetivos associados ao outro social e às relações afetivas que se constituem no espaço pedagógico, especialmente entre professor e estudantes.

A respeito, compreendemos que os sistemas relacionais, a relação social, por si só, não possibilita a expressão criativa no trabalho pedagógico do professor. É preciso mais que vínculos sociais. É fundamental a formação de vínculos afetivos. São estes que podem engendrar os processos simbólicos e emocionais, a configuração e reconfiguração subjetiva e a condição de sujeito do professor no trabalho pedagógico criativo. Seriam, portanto, relações sociais significativas, em que os "participantes", os alunos, se tornam um outro social relevante para o movimento subjetivo. Assim, entendemos que não é qualquer relação social 
que pode oportunizar a criatividade no trabalho pedagógico e o movimento na subjetividade do professor. São aquelas relações em que o estudante se constitui como um outro social, em que a afetividade se faz presente, há emoções e sentimentos entre os envolvidos.

Desse modo, em relação a nossa compreensão acerca da criatividade como processo complexo da subjetividade humana, construímos uma hipótese geral de que os processos subjetivos que configuram a criatividade no trabalho pedagógico do professor são singulares, históricos e atuais e se relacionam de forma recursiva aos próprios processos de movimentos em sua subjetividade. Considerando o que afirma Morin (2005, p. 74): “[...] um processo recursivo é um processo onde os produtos e os efeitos são ao mesmo tempo causas e produtores do que os produz." A nossa construção, assim, pautou-se no entendimento de que a expressão criativa no trabalho pedagógico pode gerar a possibilidade de movimentações subjetivas no professor; isto é, as situações educativas caracterizadas pela produção de novidades com valor para o processo de aprendizagem e desenvolvimento dos estudantes podem oportunizar o surgimento de situações não previstas que favoreçam a produção de sentidos subjetivos e os processos de (re) configuração subjetivas. Ao mesmo tempo, para a criação dessas novidades pedagógicas com valor para a aprendizagem dos alunos, fazem-se necessários os processos de movimentação subjetiva no professor e o exercício da sua condição de sujeito, sentidos e recursos subjetivos que participam do trabalho pedagógico criativo e um conjunto de configurações subjetivas e processos subjetivos que integram a condição de sujeito do docente em sua atuação profissional.

Relacionada a essa hipótese geral, consideramos que a criatividade no trabalho pedagógico do professor envolve a formação de relações e vínculos afetivos entre professores e estudantes, as quais, por sua constituição subjetiva, podem favorecer ou não essa criatividade. No curso dessas relações, o aluno pode se tornar um outro social que participa da expressão criativa do professor no contexto educativo, por meio de (novas) necessidades educativas que, aliadas à organização subjetiva do docente, podem mobilizar processos e recursos subjetivos que participam da sua criatividade no trabalho pedagógico.

Por outro lado, Mitjáns Martínez (2009a) amplia a compreensão da criatividade como processo complexo da subjetividade humana, quando nos apresenta a possibilidade da criatividade revelar-se em sua dimensão funcional. Esta pode ser considerada como um processo de produção de novidades significativas para o próprio funcionamento subjetivo e para o desenvolvimento do sujeito, indicando as possíveis relações entre a criatividade e o 
desenvolvimento subjetivo. Para a referida autora (2009a, p. 33), a criatividade em sua dimensão funcional constitui-se como:

[...] um processo de constituição e de reconstituição de configurações subjetivas implicadas no desenvolvimento do sujeito e como forma de funcionamento do sujeito psicológico, caracterizada pela autonomia e pela singularidade no enfrentamento das exigências pessoais e sociais perante as quais está colocado.

A compreensão de processos criativos nessa direção ressalta o papel da criatividade como uma forma específica de expressão da subjetividade em diferentes momentos. Nesse caso, a criatividade é caracterizada como um processo de configuração e reconfiguração da subjetividade que se expressa por meio de formas autônomas e singulares na ação do sujeito nos diferentes espaços sociorrelacionais de que participa (MITJÁNS MARTÍNEZ, 2009a).

Dessa maneira, segundo Mitjáns Martínez (2009a) a criatividade se expressaria na subjetividade pelo menos de duas maneiras: a) nos processos de reestruturação das configurações subjetivas; b) como uma função do sujeito psicológico caracterizada pela assunção de alternativas autônomas e singulares de ação nas diferentes situações de enfrentamento pessoalmente significativas, aspectos que investigamos nesta pesquisa.

Nessa dimensão funcional, a criatividade não teria um valor conferido por outros ou associada a um produto. $\mathrm{O}$ seu verdadeiro critério definidor seria o processo de mudança, de novidade, bem como a sua significação para o funcionamento integral da subjetividade. Para a autora supracitada, "essa possibilidade de constituição e reestruturação de configurações subjetivas e do exercício da função criativa do sujeito pode, de forma recursiva, 'alimentar' o próprio processo de criatividade.” (MITJÁNS MARTÍNEZ, 2009a, p. 35).

Pautadas nesses aportes acerca da criatividade como processo complexo da subjetividade humana e da possibilidade de a criatividade se expressar em uma dimensão funcional, nos aproximamos a seguir de um caráter mais "instrumental” da expressão criativa no trabalho pedagógico, tendo em vista os seus critérios definidores e sua compreensão nas práticas educativas.

2.2.2 A criatividade no trabalho pedagógico: a produção de novidades com valor para a aprendizagem e desenvolvimento dos alunos

Nesta pesquisa, buscamos definir trabalho pedagógico a partir do diálogo com diferentes autores. Nesse processo de definição, consideramos o que afirma Freitas (1995, p. 94). O autor, ao discutir a teoria educacional e a teoria pedagógica, propõe que o termo didática seja subsumido ao de organização do trabalho pedagógico, compreendendo, este 
último, em dois níveis: “[...] a) como o trabalho pedagógico que, no presente momento histórico, costuma desenvolver-se predominantemente em sala de aula; e b) como organização global do trabalho pedagógico da escola, como projeto político-pedagógico da escola."

Em consonância com Freitas (1995), Villas Boas $(1993,2004)$ afirma que a expressão trabalho pedagógico possui dois significados: em sentido restrito, estaria limitado à interação professor-aluno no espaço da sala de aula e outros da instituição educativa. No segundo significado, o trabalho pedagógico refere-se àquele realizado por toda a instituição, é entendido como o trabalho realizado em parceria entre os integrantes do contexto escolar que visa à aprendizagem do saber sistematizado. De acordo com a citada autora (2004, p. 183), essa perspectiva mais ampla envolve o "[...] trabalho realizado por toda a escola; não apenas aquele realizado diretamente com os alunos, mas também o que auxilia a realização deste [...]". Abrange, com isso, tanto os demais integrantes, como outras atividades escolares que colaboram, direta ou indiretamente, para a formação dos estudantes: os momentos da coordenação pedagógica, a secretaria escolar, a orientação educacional, os servidores da merenda, a biblioteca, a estrutura administrativa, as reuniões com as famílias, de professores, palestras, comemorações, etc. (VILLAS BOAS, 2004).

Consideramos que essa articulação dos diferentes profissionais que atuam no trabalho pedagógico, como aponta Villas Boas (1993, 2004), decorre do que afirma Tardif e Lessard (2012, p. 28): a docência é um trabalho interativo, pois ensinar é trabalhar com seres humanos, sobre seres humanos e para seres humanos. Situação em que a presença de "objeto humano" modifica profundamente a natureza do trabalho e, de forma consequente, a atividade do trabalhador, que se caracteriza pela interação humana, as relações entre pessoas.

Entendemos, então, que o trabalho pedagógico ocorre nesse espaço interativo, é um conjunto de crenças, pressupostos teóricos, concepções (sobre educação, aluno, ensino, dentre outras), de práticas e ações educativas planejadas e realizadas por professores com a finalidade de favorecer a aprendizagem e desenvolvimento dos estudantes, o que ocorre em um trabalho conjunto com os próprios alunos e outros profissionais da educação. E, por isso, inclui o trabalho docente e as pessoas que participam da dinâmica educativa.

Em nosso estudo, compreendemos que pesquisamos a criatividade no trabalho pedagógico desenvolvido, de forma predominante, entre professores e estudantes. Isso porque, consideramos que o trabalho pedagógico criativo do professor emerge nos espaços interativos que se formam na instituição educativa, o que inclui também os alunos, os outros profissionais e a própria comunidade educativa; compreende a história das relações sociais 
dos diferentes participantes do contexto escolar. Aspecto esse que implica considerar que a expressão criativa no trabalho pedagógico do professor é contextual, envolve elementos da subjetividade social daquela instituição específica, das subjetividades individuais dos profissionais, dos estudantes e daqueles que compõem o trabalho pedagógico realizado.

Para Mitjáns Martínez (2004, 2008a, 2008b), a criatividade como processo complexo da subjetividade humana revela-se no trabalho pedagógico por meio de dois critérios definidores: a novidade e o valor para os processos de aprendizagem e desenvolvimento dos estudantes. Entender a criatividade por meio de tais critérios remete à consideração de que a expressão criativa no curso das diferentes práticas educativas não significa apenas fazer "diferente" ou inserir novidades. É preciso que essas novidades favoreçam a aprendizagem e ofereçam maiores oportunidades para a formação dos estudantes.

Esses critérios definidores da criatividade no trabalho pedagógico são, portanto, relativos (MTIJÁNS MARTÍNEZ, 2008a). Requerem a compreensão dos diferentes aspectos que participam e integram as práticas educativas, como os valores e as crenças que constituem o espaço escolar e perpassam as escolhas educativas, as práticas conhecidas e legitimadas naquela instituição, os professores, os estudantes, as relações com as famílias e as possíveis formas de participação, os demais funcionários, o currículo e a proposta pedagógica prescrita e também a que se constituí nas ações educativas.

Por isso, concordamos com Mitjáns Martinez (2008a), para quem os processos criativos no trabalho pedagógico não dizem respeito a modismos e práticas isoladas. Ao contrário, são sistêmicos e abrangem diferentes aspectos do trabalho pedagógico, que não se reduz a métodos de ensino. Para a autora, a complexidade da criatividade solicita ações também complexas no contexto educativo, se a pretensão é permitir o seu desenvolvimento. Em suas palavras (MITJÁNS MARTÍNEZ, 2004, p. 91):

\footnotetext{
A necessidade de estratégias complexas em contraposição a formas parciais de abordar o problema justifica-se pela própria complexidade constitutiva do processo criativo, do qual participam as configurações criativas constituídas na história de vida individual, formadas por sentidos subjetivos diversos.
}

Isso evidencia que a criatividade no trabalho pedagógico se constitui e desenvolve com base em complexas situações entre os indivíduos e os contextos sociorrelacionais em que ele participa, isto é, se produz na articulação sujeito-contexto. Desse modo, não é apenas uma ferramenta que se aplica e utiliza (MITJÁNS MARTÍNEZ, 2008b). Mais que isso, envolve o Sistema Didático Integral (2003a, 2008a, 2008c) composto por diferentes aspectos do trabalho pedagógico em sala de aula, elencados por Mitjáns Martínez (2003a, 2008a, 2008b) como: 
a) a formulação e seleção dos objetivos de aprendizagem no que diz respeito à participação dos estudantes e uma possível individualização dos objetivos propostos e, com isso, o favorecimento da implicação pessoal deles para sua aprendizagem (MITJÁNS MARTÍNEZ, 2003a);

b) a seleção e organização dos conteúdos a serem trabalhados tendo em vista os objetivos de aprendizagem formulados com os estudantes (MITJÁNS MARTÍNEZ, 2003a);

c) as estratégias e métodos de ensino que favoreçam o posicionamento ativo por parte dos estudantes, envolvendo a proposição de problemas e sua resolução criativa, o estímulo para a construção de questionamentos, fundamentação e defesa de posições próprias (MITJÁNS MARTÍNEZ, 2003a);

d) a organização do processo docente que precisa ser planejado, acompanhado e avaliado quanto a sua pertinência e eficácia (MITJÁNS MARTÍNEZ, 2003a);

e) a natureza das tarefas a serem realizadas e as orientações para sua realização, valorizando-se as atividades de caráter produtivo e não apenas reprodutivo (MITJÁNS MARTÍNEZ, 2003a);

f) a natureza da bibliografia e do material didático que supõe conhecimento e mobilização de informações no campo de atuação profissional, docente (MITJÁNS MARTÍNEZ, 2003a);

g) o sistema de avaliação e auto-avaliação da aprendizagem relacionados aos objetivos de aprendizagem e sua individualização (MITJÁNS MARTÍNEZ, 2003a);

h) as relações professor-aluno e o clima comunicativo-emocional presente em sala de aula e na instituição educativa que favoreça o desenvolvimento da criatividade e sua expressão, a responsabilidade, liberdade e disciplina (MITJÁNS MARTÍNEZ, 2003a).

Esses aspectos que compõem o Sistema Didático Integral são articulados entre si e foram inicialmente formulados para favorecer o desenvolvimento da criatividade dos estudantes, mas, como destaca Mitjáns Martínez (2008a), referem-se a novas formas de realizar o trabalho pedagógico. Essas formas se constituem como expressões potenciais de criatividade no trabalho pedagógico do professor, considerando-se a necessidade de que o processo pedagógico se concretize em termos de níveis qualitativos de aprendizagem para ser dito como criativo. 
A propósito, esclarecemos que nos referimos à aprendizagem escolar, a qual, como afirma Tunes et al. (2006), constitui-se como um processo não apenas individual, mas um processo de natureza social, própria da instituição escolar. Esta possui, dentre diferentes possibilidades, o foco na transmissão da cultura elaborada pela humanidade, na aproximação aos conceitos científicos, que se constituem, de fato, em elementos centrais dos currículos escolares e das disciplinas.

Entendemos, ainda, que a aprendizagem, como nos indica a Teoria da Subjetividade na perspectiva Histórico-Cultural, está para além da assimilação ou apropriação dos conhecimentos. Caracteriza-se pela possibilidade de produção, de geração de ideias, reflexões próprias, de pensamento, utilização do aprendido em outras situações. Trata-se de um processo subjetivo, que implica a produção de sentidos subjetivos e a condição de sujeito do aprendiz (GONZÁLEZ REY, 2008, 2009, 2012; MITJÁNS MARTÍNEZ, 2009b; MITJÁNS MARTÍNEZ; GONZÁLEZ REY, 2012), aspectos que podem evidenciar-se em formas complexas de aprendizagem e em outras formas presentes no contexto escolar, como a mecânica e compreensiva (MITJÁNS MARTÍNEZ; GONZÁLEZ REY, 2012).

Nessa definição, resgata-se a condição de sujeito em seu processo de aprendizagem, desdobrando-se no que González Rey (2008, 2009, 2012) chama de sujeito que aprende, categoria que explicita a ênfase na produção própria, na capacidade geradora do aprendiz, no seu envolvimento em iniciativas, alternativas e caminhos que podem conduzir a uma aprendizagem compreensiva eficiente, em uma organização diferenciada do material aprendido (GONZÁLEZ REY, 2008, 2009, 2012). Em suas palavras encontramos (GONZÁLEZ REY, 2008, p. 40):

\begin{abstract}
O aluno torna-se sujeito de sua aprendizagem quando é capaz de desenvolver um roteiro diferenciado em relação ao que aprende e a se posicionar crítica e reflexivamente em relação à aprendizagem. Esse posicionamento só será possível na medida em que ele é capaz de gerar sentidos subjetivos em relação ao que aprende.
\end{abstract}

A aprendizagem abrange, portanto, a produção de sentidos subjetivos provenientes tanto da experiência escolar, como de outros espaços sociais nos quais o estudante participa, produções que se relacionam na aprendizagem (GONZÁLEZ REY, 2008, 2012). Além disso, conduz ao reconhecimento da mobilização das configurações subjetivas que integram a produção subjetiva no curso do aprender e ao reconhecimento das condições sociais em que ocorre o processo de ensino e aprendizagem, as quais se definem pelas experiências que a pessoa produz diante delas (MITJÁNS MARTÍNEZ, 2009b; GONZÁLEZ REY, 2012). Por isso, a ação pedagógica mostra-se como potencial, mas não determinante para garantir a aprendizagem, “[...] isso ocorre porque qualquer ação intencional adquire valor real em 
termos de aprendizagem e desenvolvimento, em função dos sentidos subjetivos gerados nos sujeitos.” (MITJÁNS MARTÍNEZ, 2009b, p. 226).

A aprendizagem, ao ser compreendida nessa perspectiva, implica considerar os possíveis impactos que pode ter no desenvolvimento dos estudantes, como sugere Mitjáns Martínez (2009b). Pautada no marco teórico da perspectiva Histórico-Cultural, “[...] na qual se confere à aprendizagem um papel essencial nos processos de desenvolvimento" (MITJÁNS MARTÍNEZ, 2009b, p. 215), a autora afirma:

Interessa-nos especialmente destacar a significação dada por Vigotski (1934/1968) à aprendizagem escolar, no desenvolvimento de formas de pensamento que não são inerentes à natureza humana e que, ao mesmo tempo em que constituem expressão do processo cultural de humanização, resultam em importantes instrumentos nas formas complexas de comportamento humano.

Mitjans Martínez (2009b) destaca essa relação entre aprendizagem e desenvolvimento no ensino da pós-graduação. No entanto, compreendemos que pode estar presente em outros momentos da escolarização, oportunizando, como ela mesma diz, não apenas a aquisição de nível maior de conhecimentos e habilidades investigativas, como também o desenvolvimento de aspectos relevantes do desenvolvimento humano e do desenvolvimento da subjetividade.

A consideração dos processos de aprendizagem e desenvolvimento nessa direção indica que a expressão criativa no trabalho pedagógico do professor para favorecê-los, mais do que Mitjáns Martínez propõem no Sistema Didático Integral, envolve outros momentos e espaços que compõe a dinâmica escolar, como a coordenação pedagógica, o planejamento do ensino, as reuniões entre os professores, as atividades desenvolvidas pelos demais integrantes do contexto educativo (pedagogos, equipes de apoio, orientadores educacionais, dentre outros). Por isso, em nossa pesquisa ampliamos os espaços de investigação da criatividade no trabalho pedagógico do professor para além do que a autora aborda, nos diferenciando de seus estudos.

Essa visão mais ampla da expressão criativa no trabalho pedagógico requer, por sua vez, a consideração de que a criatividade abrange a caracterização das principais ações desenvolvidas no espaço escolar, as inter-relações entre os integrantes da dinâmica educativa e a subjetividade social da sala de aula e da instituição como organização de ensino (MITJÁNS MARTÍNEZ, 2008b). Pode ocorrer, então, em diferentes níveis e formas, como alerta Mitjáns Martínez (2008c), de modo que um professor pode ser mais ou menos criativo em certos momentos do trabalho pedagógico, bem como em certas práticas de ensino.

As possibilidades de expressão criativa sofrerão influências de múltiplos fatores, os quais nos aproximamos ao analisar os processos subjetivos que participam da criatividade no trabalho pedagógico do professor. Destes processos, consideramos a participação da 
imaginação do docente, que, diante do processo de planejamento e realização de suas práticas criativas, pode utilizar processos imaginativos para produzir novidades com valor para a aprendizagem e desenvolvimento dos estudantes.

A imaginação, segundo González Rey (2014), está presente em toda construção humana criativa, constituindo-se como condição necessária e qualidade que aponta a presença de processos subjetivos em todas as atividades e funções do homem. Mitjáns Martínez (2014, p. 73), em consonância com o citado autor, explica que a imaginação não é uma função psicológica específica, e sim um “[...] processo complexo da ordem da subjetividade, isto é, como produção simbólica de diferentes ordens (imagens, ideias, representações) que expressa o caráter gerador da subjetividade.”, e que pode participar de diferentes maneiras da aprendizagem criativa: como ferramenta para transcender a experiência vivida, como elemento constitutivo dos processos de compreensão e como elemento essencial na produção de conhecimento novo.

Nessa direção, investigamos como a imaginação pode participar da criatividade no trabalho pedagógico do professor, quais poderiam ser as vias de integração entre os processos imaginativos do docente e sua expressão criativa na prática docente. E, mais, como as experiências docentes anteriores, a formação acadêmica, o envolvimento com os estudantes e seu processo de aprendizagem, e as intenções educativas que perpassam as escolhas educativas podem repercutir na criatividade no trabalho pedagógico do professor.

Dentre tais influências entendemos que pode participar a forma como professor subjetiva a aprendizagem dos estudantes, o que abrange processos simbólicos e emocionais relacionados ao aprender; bem como, sua proposta singularizada a respeito dos objetivos pedagógicos que propõe para o processo de ensino, o que almeja para o atendimento educativo proposto. Consideramos, assim, que a criatividade no trabalho pedagógico do professor está imbuída de intencionalidade pedagógica, compreendida como o propósito educativo, a finalidade das práticas educativas oferecidas aos estudantes.

$\mathrm{Na}$ perspectiva que assumimos, essa intencionalidade se articula ao exercício da condição de sujeito do professor, que, de forma intencional, direciona o seu trabalho pedagógico. Desse modo, não basta apenas inserir novidades para que elas tenham valor no processo de aprendizagem; torna-se essencial que tenham relação com os objetivos de aprendizagem propostos para os estudantes em questão. Sendo assim, não se trata, apenas, de caracterizar a prática educativa como nova no contexto em que ela se realiza, para que tenha valor, é preciso que haja relação com o que se deseja que os alunos aprendam. Isso envolve 
tanto os objetivos de aprendizagem específicos para cada um deles, como os objetivos mais amplos do processo de ensino.

Essa intencionalidade, portanto, pode se vincular a outros processos que participam da criatividade no trabalho pedagógico do professor, como os conhecimentos mobilizados na expressão criativa. Destes, nos perguntamos, inicialmente: são os conhecimentos a respeito da docência, da aprendizagem, do desenvolvimento humano, da criatividade e/ou do desenvolvimento curricular que participam do trabalho pedagógico criativo? Como os conhecimentos e os processos de reflexão relacionados às concepções de criança e ao papel do professor, dentre outras, também repercutem?

Atrelada à intencionalidade pedagógica e aos conhecimentos, consideramos que a implicação do professor e a mobilização dos recursos subjetivos relacionados à criatividade em sua prática docente podem estar vinculadas à forma como o professor subjetiva a função social da educação. Essa função envolve os princípios educativos, as concepções associadas ao estudante (criança, infância e adolescência), ao que é ser professor e a educação, bem como à finalidade do atendimento pedagógico oferecido por ele. Aspectos esses que se constituem e são subjetivados com base na produção de sentidos subjetivos que emergem na ação docente e integram a subjetividade individual do professor, envolvendo sua experiência acadêmica, profissional e pessoal, sua história de vida e as relações que construiu ao longo de sua atuação.

Tal construção articula-se à compreensão de que a criatividade no trabalho pedagógico do professor é uma produção subjetiva atual e também um processo, caracterizado, dentre outros aspectos, por ser: a) histórico, que se constitui e se define ao longo da trajetória de vida do professor e de seu desenvolvimento subjetivo; b) social, porque abrange as relações sociais, o outro social; c) cultural, diferenciando-se de acordo com os elementos e as particularidades locais em que se insere o professor. Isso implica a consideração de que a expressão criativa no trabalho pedagógico tem em sua essência as características do movimento e da imprevisibilidade, não se refere a padrões universais e pré-definidos.

Essa mobilidade da criatividade no trabalho pedagógico está articulada, ainda, aos processos de configuração e reconfiguração subjetivas associados aos sentidos subjetivos que emergem na atuação docente e aos núcleos subjetivos que participam do trabalho pedagógico, os quais se modificam continuamente no decorrer das experiências profissionais, do cotidiano educativo, das ações e relações constituídas pelo professor. Esses foram aspectos que nos aproximamos em nossa pesquisa. A propósito, Mitjáns Martínez (2004, p. 88) afirma: 
Todo fato ou experiência vividos pelo sujeito terão um sentido subjetivo produzido por meio dos recursos e das configurações de sentido que se atualizam no sujeito no momento da ação. Essa produção diferenciada é uma característica específica da criatividade estudada em uma perspectiva histórico-cultural da subjetividade.

Nesse contexto estão presentes e integram a dinâmica educativa os processos de comunicação estabelecidos pelo professor, os quais são processos privilegiados para a constituição de sentidos subjetivos e a proposição de situações favoráveis à aprendizagem e desenvolvimento dos estudantes. São esses processos que revelam as relações entre as pessoas que participam do trabalho pedagógico e a forma como a função social da educação está subjetivada pelo professor.

Assim, o nosso estudo considerou que os processos de comunicação nos quais os professores participam no espaço escolar e em outros contextos podem se caracterizar como meios privilegiados para produções subjetivas, gerar a constituição de sentidos subjetivos produzidos na ação docente, e, com isso, movimentos subjetivos que se relacionam à criatividade no trabalho pedagógico.

Além disso, consideramos que os processos comunicativos constituem, como afirma Mitjáns Martínez (2004), aspectos essenciais para a compreensão das experiências emocionais que o professor experimenta na realização das atividades docentes, bem como para emergência de processos simbólicos e emocionais associados à expressão criativa no trabalho pedagógico.

Pautadas nesses aportes teóricos, apresentamos, de forma sintética, as ideias iniciais que se relacionam à hipótese geral apresentada anteriormente. São elas: o entendimento de que a criatividade no trabalho pedagógico do professor é permeada por intencionalidade pedagógica, que por sua vez, fundamenta-se em certos conhecimentos e na maneira como a função social da educação está sendo subjetivada pelo professor. Ademais, tivemos em vista que os processos comunicativos são momentos privilegiados para a constituição e expressão criativa no trabalho pedagógico e suas inter-relações com os processos subjetivos do professor.

Desse modo, para compreendermos a criatividade no trabalho pedagógico do professor faz-se necessária uma abordagem epistemológica e metodológica que possibilitam entender e considerar os processos subjetivos, históricos, culturais e sociais vinculados ao professor e sua atuação profissional. 


\section{EPISTEMOLOGIA QUALITATIVA DE GONZÁLEZ REY E METODOLOGIA DE INVESTIGAÇÃO}

A educação como prática social envolve as diferentes redes que integram o contexto escolar, os enlaces e as teias sociais que constituem a realidade mais ampla. Por isso, não é possível entendê-la de forma linear, com certezas absolutas e regras universais. Trata-se de uma prática complexa, o que para Morin (2005) pressupõe as infinitas inter-retroações, contradições e incertezas que destacam as imperfeições e o reconhecimento do irredutível.

Nesse contexto, entender a criatividade como expressão da singularidade e complexidade humana solicitou desta pesquisa uma perspectiva epistemológica e metodológica que viabilizasse a compreensão da diversidade e diferentes possibilidades de criação no contexto escolar, as quais, de alguma forma, podem gerar movimentos na subjetividade do docente.

A construção de conhecimentos científicos relacionados ao trabalho pedagógico criativo e as inter-relações com o movimento na subjetividade do professor solicitou, ainda, a compreensão do Paradigma da Complexidade. Dessa forma, para a demarcação dos critérios de cientificidade, se faz necessário considerar as proposições de Morin (2005): quanto mais complexo, mais é diverso, há mais interações, acasos e desintegrações.

Reconhecer a diversidade nos processos criativos remete, também, ao que afirma González Rey (2007b). Para ele, a teoria da complexidade oferece a compreensão sistêmica e processual da realidade, recuperando o valor das definições ontológicas, que conduz, por sua vez, a uma representação diferenciada da ciência e dos princípios epistemológicos. Realidade que é vista não como complicação, mas com base no seu “[...] caráter desordenado, contraditório, plural, recursivo, singular, indivisível e histórico que a caracteriza" (MITJÁNS MARTÍNEZ, 2005, p. 4).

É nessa realidade processual e histórica que se desenvolve e expressa a criatividade do professor no contexto escolar. Para González Rey (2007b) entender a criatividade a partir da complexidade significa, em muitas ocasiões, que a possibilidade criativa é, em geral, uma opção não prevista da ordem estabelecida, que define as exigências institucionais às ações humanas. É precisamente por isso que a criatividade é uma expressão singular subjetiva, capaz de produzir a subversão ao que está posto naquele espaço social.

Aliado a isso, o autor (GONZÁLEZ REY, 2007b, p. 133) afirma:

$\mathrm{O}$ atual desenvolvimento de teorias voltadas à compreensão de diferentes sistemas da realidade sobre os princípios da complexidade oferece apoio às posições que 
temos desenvolvido a respeito da subjetividade, tanto nos aspectos teóricos quanto nos epistemológicos.

González Rey (1997, 2002, 2005b, 2007b) propôs, então, uma posição epistemológica diferenciada que denomina como Epistemologia Qualitativa. De acordo com o autor, essa abordagem foi introduzida com o objetivo de acompanhar as necessidades das pesquisas qualitativas em psicologia e como uma forma de atender as exigências epistemológicas inerentes aos estudos que envolvem a subjetividade como parte constitutiva do indivíduo e de espaços sociais (GONZÁLEZ REY, 2002, 2005b).

Para compreender sua proposta, é importante uma aproximação aos três princípios expostos pelo autor, os quais se articulam e se fundamentam mutuamente. $\mathrm{O}$ primeiro deles envolve a compreensão do caráter construtivo-interpretativo do conhecimento, o que implica o entendimento desse último como uma produção e construção humana "[...] e não como apropriação linear de uma realidade que se apresenta" (GONZÁLEZ REY, 2005b, p. 5). A interpretação por parte do pesquisador se caracteriza, então, como um processo diferenciado que, no decorrer da pesquisa, atribui significados às diferentes manifestações do estudado, convertendo-os em processos teóricos gerais. A pesquisa é compreendida, por sua vez, como um processo particular na produção teórica, decorrendo da interpretação do pesquisador (GONZÁLEZ REY, 2002).

Esse princípio relaciona-se com o seguinte, em que González Rey (2002, 2005b) defende a legitimidade do singular como instância de produção do conhecimento científico. Tal afirmativa abrange a consideração do estudo de casos e de suas informações pelo que representam para o modelo teórico em construção e por sua pertinência ao sistema teórico que está se constituindo. Em relação a esse aspecto, o autor (2005b, p. 11) nos explica: "legitimação do singular como fonte do conhecimento implica [...] considerar a pesquisa como produção teórica, entendendo por teórico a construção permanente de modelos de inteligibilidade que lhe dê consistência.".

Para tanto, é preciso entender o terceiro princípio da Epistemologia Qualitativa: a compreensão da pesquisa como um processo de comunicação, um processo dialógico, o que torna os processos comunicativos entre o pesquisador e os participantes da pesquisa meios para o acesso e conhecimento das configurações e processos de sentidos subjetivos. Isso remete ao valor do diálogo e dos momentos informais como situações produtoras de informações relevantes para a produção teórica (GONZÁLEZ REY, 2002, 2005b). A comunicação, portanto, “[...] será via em que os participantes de uma pesquisa se converterão 
em sujeitos, implicando-se no problema pesquisado a partir de seus interesses, desejos e contradições.” (GONZÁLEZ REY, 2005b, p. 14).

Esses princípios nortearam o processo de pesquisa, sendo o estudo de casos considerado como método de estudo pertinente à singularidade que caracteriza os processos criativos no trabalho pedagógico e os movimentos na subjetividade do professor.

\subsection{Objetivos da Pesquisa}

Antes de apresentamos a metodologia e os procedimentos desta pesquisa, retomamos, a seguir, os objetivos deste estudo, que possuía como objetivo geral: compreender processos subjetivos que configuram a criatividade no trabalho pedagógico do professor e suas inter-relações com o movimento em sua subjetividade. Para alcançá-lo, indicamos os seguintes objetivos específicos:

a) analisar expressões de criatividade no trabalho pedagógico do professor;

b) analisar a subjetividade individual do professor que expressa criatividade no trabalho pedagógico, com foco na condição de sujeito e nos principais núcleos subjetivos que participam dessa criatividade;

c) analisar o movimento na subjetividade individual do professor que desenvolve um trabalho pedagógico criativo.

\subsection{Metodologia de investigação}

Para a realização desta pesquisa, realizamos estudo de casos conforme definições a seguir.

\subsubsection{Estudo de casos: definição}

O estudo de casos é definido em sua condição qualitativa de singularidade, "[...] em que aparece como expressão diferenciada e única de uma qualidade em processo de estudo." (GONZÁLEZ REY, 2002, p. 157). Isso faz dessa alternativa metodológica uma via pertinente ao estudo da criatividade no trabalho pedagógico do professor, o qual se vincula à singularidade e foge a padronizações e propostas didáticas estabelecidas a priori.

É essa possibilidade de estudo a partir do singular que torna o estudo de casos uma exigência epistemológica para o conhecimento da subjetividade. Trata-se de um estudo 
intensivo e singular que se caracteriza como meio privilegiado para construção de informações a respeito dos processos subjetivos, que, marcados pela historicidade e pelo seu caráter irrepetível, solicitam estudos profundos e particulares acerca de sua constituição (GONZÁLEZ REY, 1997, 2002, 2005b, 2007b).

No estudo da subjetividade, faz-se necessário considerar a complexidade das produções simbólicas e emocionais, que envolvem as experiências e a ação dos indivíduos em contextos reais. Para Yin (2010), o estudo de casos é um método que surge da necessidade de entender fenômenos complexos e que permite a aproximação às características holísticas e significativas dos eventos da vida real. É pertinente em estudos contemporâneos e, quando não há a manipulação, o controle do pesquisador sobre o objeto de investigação. Aspectos esses que coadunam com a relevância desse método de estudo para a compreensão da singularidade da expressão criativa do professor no trabalho pedagógico e suas inter-relações com o movimento da subjetividade do docente.

A singularidade, no entanto, não diz respeito ao significado restrito de individualidade, como nos indica González Rey (2002). Para Lüdke e André (1986), o estudo de caso pode ser similar a outros, mas é ao mesmo tempo distinto, próprio. O interesse incide no que tem de particular, mesmo que se reconheçam certas semelhanças com outros casos ou situações.

Torna-se, com isso, momento essencial na produção de conhecimento, representando uma possibilidade de acesso às evidências únicas da subjetividade individual e social (GONZÁLEZ REY, 2002). González Rey (2002, p. 156) indica isso ao afirmar:

Damos grande importância ao estudo de casos como procedimento geral da pesquisa qualitativa. Esse estudo representa uma ferramenta privilegiada para o acesso a uma fonte diferenciada que, de forma única, nos apresenta simultaneamente a constituição subjetiva da história própria (subjetividade individual) e uma forma não repetível de subjetivação da realidade social que o sujeito coube viver.

Essa possibilidade de estudo que abrange os aspectos individuais e sociais relaciona-se com o que Lüdke e André (1986) apontam como uma das características do estudo de casos: a interpretação em contexto. Essa perspectiva está em consonância com as afirmações de Yin (2010). Para o autor, esse método possibilita o estudo de um fenômeno em profundidade e em seu contexto de vida real, envolve, necessariamente, as condições contextuais em que ocorre.

Consideramos, assim, que para o estudo da criatividade no trabalho pedagógico do professor esse é um ponto central do processo de pesquisa, que requer um olhar atento do pesquisador acerca do contexto da instituição e de outros campos da vida do docente. Ademais, concordamos com Neubern (2005, p. 63), que afirma que a noção de subjetividade precisa privilegiar as especificidades e os cenários do próprio sujeito em estudo, “[...] cujas 
qualidades emergentes, expressas na forma de linguagem, de sentidos e de configurações específicas, apontam para uma complexidade própria da psique [...].” (grifo do autor).

Desse modo, para esta pesquisa, optamos pela realização de estudo de casos, que teve como foco processos subjetivos que configuram a criatividade no trabalho pedagógico do professor e suas inter-relações com o movimento em sua subjetividade. Os critérios de escolha dos participantes de tais estudos serão apresentados em seguida.

\subsubsection{Os participantes e procedimentos da pesquisa}

A realização de estudo de casos como via para a construção de informações requer a identificação daqueles que podem ter significativa contribuição para o modelo teórico que está sendo formulado. É nessa perspectiva que foram sugeridos os critérios para seleção dos participantes desta pesquisa, que envolveu estudos acerca dos processos criativos e subjetivos do professor no trabalho pedagógico.

Para a seleção dos professores, utilizamos como critério inicial que trabalhassem em instituições públicas e que desenvolvessem, preferencialmente, a Pedagogia de Projetos. A opção pelas instituições que faziam uso de projetos decorreu das conclusões da pesquisa de mestrado de Mourão (2004), que, em sua análise, afirmou que há uma relação recursiva entre os sentidos subjetivos da criatividade do professor e sua prática pedagógica com projetos. A autora afirmou, ainda, que os conflitos e as contradições que surgem na prática com projetos configuram-se como uma situação potencial para o desenvolvimento do sentido subjetivo da criatividade e à prática docente. Sugeriu, com isso, que diante da prática de projetos pode ocorrer a expressão criativa e a produção de sentidos subjetivos relacionados à criatividade.

Aliado a isso, compreendemos que a criatividade no trabalho pedagógico do professor abrange a formação de relações e vínculos afetivos entre professores e estudantes, os quais, por sua constituição subjetiva, podem favorecer ou não a expressão criativa do docente no contexto educativo. Após a análise de diferentes alternativas, propomos, então, que esta pesquisa fosse desenvolvida com os professores que atuassem em instituições de educação infantil ou de anos iniciais do ensino fundamental. Partimos do princípio de que, nessas etapas, pode ocorrer maior interação entre os indivíduos que compõem a dinâmica escolar, considerando que há apenas um professor por turma e que eles se encontram diariamente com seus alunos durante todo ano letivo. Isso favoreceria a formação de vínculos afetivos e a atenção à diversidade dos estudantes em seu processo de aprendizagem e desenvolvimento. 
Com base nos critérios acima, iniciamos a Fase 1 da pesquisa, momento em que foram selecionados os participantes do estudo. Buscamos, junto aos professores-formadores que participam de cursos de formação em serviço, coordenadores pedagógicos, dentre outros, a identificação de professores que produzissem novidades em sua prática educativa com valor para a aprendizagem e desenvolvimento dos estudantes.

Nesses contatos, uma formadora nos indicou uma participante, Diana, com a qual iniciamos a fase 1. No curso das observações, que aconteceram ao longo de um mês, interpretamos poucas expressões criativas da professora. Por isso, não prosseguimos a pesquisa com ela.

Outra formadora, que naquele ano estava como coordenadora pedagógica, apresentou a nossa proposta de pesquisa no jornal interno da instituição. Ananda ${ }^{4}$, então, se propôs a integrar o estudo. Essa coordenadora, também, indicou a professora Júlia, que após contato inicial, aceitou participar do estudo. Uma vice-diretora, em conversa informal, citou o trabalho pedagógico desenvolvido por Laura, que aceitou integrar os casos. Cada uma delas atuava em uma instituição educativa específica, que serão apresentadas posteriormente.

Tivemos, ainda, o estudo de caso com o professor Paulo, que em 2013 apareceu em um jornal local tratando da inclusão de filmes no ensino médio. Ao vermos a reportagem, buscamos meios de encontrá-lo. No curso da pesquisa, entretanto, entendemos que ele não desenvolvia um trabalho pedagógico criativo, mas algumas ações educativas que poderiam ser consideradas como "novas" no contexto do ensino médio.

Desde o primeiro contato com esses professores, procuramos envolvê-los com o processo de pesquisa e criar o que González Rey (2002, 2005b, 2007b) chama de cenário da pesquisa, que compreende a "[...] fundação daquele espaço social que caracterizará o desenvolvimento da pesquisa e que está orientado a promover o envolvimento dos participantes na pesquisa" (2005b, p. 83). Nesse momento observamos, também, as indicações verbais e não-verbais dos professores a respeito do interesse em integrar o estudo.

Para a construção desse cenário de pesquisa, propomos para Ananda um diálogo a partir de trechos do filme Sociedade dos Poetas Mortos, cena em que o professor pede aos estudantes que rasguem a primeira folha do livro e depois solicita que eles construam poesias. Com base nas cenas do filme, discutimos questões vinculadas à pesquisa: como percebia aquele professor do filme, como relacionava a sua atuação com a dele; se o que ele fez foi significativo para os estudantes; como poderia ter sido diferente, dentre outras.

\footnotetext{
${ }^{4}$ Os nomes utilizados são fictícios.
} 
Devido às peculiaridades do cotidiano educativo dos demais professores, utilizamos um folder explicativo para iniciarmos o cenário de pesquisa. A partir desse material, iniciamos o processo de diálogo, indicamos a trajetória da pesquisadora como educadora e como surgiu o interesse pela criatividade no trabalho pedagógico do professor. Explicamos, ainda, o percurso proposto para o estudo.

Depois desse momento inicial, solicitamos autorização das equipes de direção das respectivas instituições, para as quais apresentamos a proposta da pesquisa. Em seguida, entramos em contato com as coordenações regionais de ensino em que atuavam e providenciamos a assinatura dos professores do termo de consentimento.

$\mathrm{Na}$ Fase 2, prosseguimos a pesquisa no contexto educativo das três professoras, que, de acordo com a fundamentação teórica apresentada, podem ser consideradas como criativas no trabalho pedagógico. Foram elas: Ananda, Júlia e Laura ${ }^{5}$. Para a escolha das participantes do estudo de casos, observamos também o interesse e disponibilidade para integrar a pesquisa.

Durante a pesquisa, desenvolvida no ano letivo de 2013, utilizamos os meios elaborados para a construção das informações, retirando da proposta inicial o instrumento Conflito de Diálogos. Apenas no caso de Laura utilizamos as informações advindas do instrumento Resolução de Situações do Cotidiano Educativo, pois compreendemos que nele havia informações peculiares. Os outros meios elaborados foram suficientes para o processo construtivo- interpretativo dos demais casos. Maiores explicações a respeito dos instrumentos utilizados na pesquisa são apresentadas no tópico seguinte.

\subsubsection{Instrumentos utilizados na pesquisa}

Na Epistemologia Qualitativa os instrumentos de pesquisa são considerados como vias de acesso à subjetividade e possuem o objetivo de instigar a expressão dos participantes, por isso "[...] definimos por instrumento toda situação ou recurso que permite ao outro expressarse no contexto da relação que caracteriza a pesquisa." (GONZÁLEZ REY, 2005b, p. 42). São considerados como meios que envolvem emocionalmente os participantes, facilitando a expressão, reflexão e (re) elaboração das questões em estudo (GONZÁLEZ REY, 2002, 2005b).

\footnotetext{
${ }^{5}$ A partir desse momento, iremos nos referir às participantes, as professoras do estudo de casos, considerando que as três foram mulheres. $\mathrm{O}$ uso de substantivos no masculino foi preservado para as colocações de autores citados e para questões gerais.
} 
Nessa perspectiva, os instrumentos formam um sistema no qual um se relaciona com o outro e representam momentos do processo mais amplo que é a pesquisa. Podem ser caracterizados como grupais, individuais, interativos, orais e escritos. Nessa diversidade, permitem a aproximação à complexidade dos processos subjetivos. Para González Rey (2002), o estudo da subjetividade requer entrar em formas complexas de expressão dos participantes da pesquisa, para assim avançar na construção do conhecimento por vias indiretas ou implícitas. Isso envolve a própria compreensão dos sentidos subjetivos e suas possibilidades de estudo. Para o autor (GONZÁLEZ REY, 2005b, p. 116):

\begin{abstract}
O sentido subjetivo não aparece de forma direta na expressão intencional do sujeito, mas sim indiretamente na qualidade da informação, no lugar de uma palavra em uma narrativa, a comparação das significações atribuídas a conceitos distintos de uma construção, no nível de elaboração diferenciado no tratamento dos temas [...], nas manifestações gerais do sujeito em seus diversos tipos de expressão etc.
\end{abstract}

Por isso, para esta pesquisa, que teve como foco uma aproximação aos processos subjetivos que configuram a criatividade no trabalho pedagógico e suas inter-relações com o movimento na subjetividade do professor, optamos por diversificar os instrumentos, usando formas escritas e orais, que permitissem retomar momentos do passado dos participantes e contemplassem situações do presente. Utilizamos, então: observação no cotidiano escolar; análise documental; entrevistas como processo; túnel do tempo; redações; completamento de frases; resolução de situações do cotidiano educativo; indicação de duas grandes premiações; assim como, os momentos informais.

\title{
Observação no cotidiano escolar
}

A observação desenvolvida na pesquisa contemplou o trabalho pedagógico das professoras que integraram o estudo de casos, incluindo seus espaços de inserção, como salas de aulas, coordenações pedagógicas, eventos e outras situações. Ocorreram em dois ou três dias seguidos da semana, o que viabilizou, com maior facilidade, as construções acerca das expressões criativas no trabalho pedagógico nas suas diferentes dimensões (relações professor-alunos, estratégias pedagógicas utilizadas, comunicação, etc.).

Para os momentos na instituição, partimos do roteiro semiestruturado proposto para esta pesquisa (APÊNDICE A), sendo registradas as principais informações observadas em um diário de bordo, com campo destinado a cada docente. O objetivo inicial desse instrumento referiu-se à construção de informações vinculadas à expressão criativa das professoras no trabalho pedagógico, às relações sociais no contexto educativo entre professores, direção e 
alunos e os indicativos de aprendizagem e desenvolvimento dos alunos. Esse foi o primeiro e o principal instrumento utilizado neste estudo.

\section{Análise documental}

A análise documental inclui materiais escritos e impressos, que podem ser utilizados como fontes de informações (ALVES-MAZZOTTI; GEWANDSZNAJDER, 1999). Nesta pesquisa, analisamos documentos relacionados às professoras e aos alunos. Das docentes, tivemos acesso a algumas avaliações feitas para os estudantes e atividades elaboradas e realizadas por elas no cotidiano educativo. Na construção das informações, buscamos compreender as relações entre os conteúdos abordados, as estratégias pedagógicas utilizadas, o caráter ativo ou reprodutivo das tarefas solicitadas aos estudantes e a sua repercussão para os processos de aprendizagem dos alunos.

Além disso, nos aproximamos dos materiais produzidos pelos próprios alunos, como: cadernos, livros, cartazes, dentre outros, procurando indicativos desse processo de aprendizagem, favorecido por meio do trabalho pedagógico criativo. Todas as análises ocorreram concomitantes às observações.

\section{Entrevistas como processo}

No contexto da Epistemologia Qualitativa as entrevistas possuem caráter flexível, aberto e dialógico; rompem com o estilo pergunta e resposta. Elas avançam na possibilidade de comunicação e expressão entre os participantes da pesquisa, tendo como propósito se transformarem em diálogos permanentes ao longo do processo de pesquisa (GONZÁLEZ REY, 2002, 2005b). A esse respeito, Amaral (2011, p. 111) afirma que “[...] é exatamente o inusitado, o novo, aquilo que não se pode prever que garante a qualidade dos indicadores a serem produzidos". Concordamos com sua afirmativa e, pautadas nessa compreensão, realizamos as entrevistas. Estas possuíam temas geradores para o diálogo, caracterizando-se como um processo que se prolongou no decorrer do estudo.

Com as professoras que seguiram na pesquisa, realizamos três entrevistas, agendadas de acordo com sua disponibilidade. Na primeira, abordamos, de forma mais específica, a trajetória de vida, pessoal e acadêmica (APÊNDICE B) das docentes. Na segunda, sua trajetória profissional (APÊNDICE C). A necessidade da terceira entrevista surgiu após o processo inicial de construção das informações, sendo abordados aspectos peculiares de cada caso. 
Dentre os objetivos de tais entrevistas estavam a aproximação a informações que nos possibilitassem construções a respeito dos principais núcleos subjetivos das professoras participantes, o que envolveu a constituição histórica dessas profissionais, os processos emocionais e simbólicos que envolveram suas experiências em diversos campos de sua vida e as relações sociais que poderiam participar e ter participado da constituição da criatividade no trabalho pedagógico e de movimentos subjetivos.

\section{Túnel do tempo}

O Túnel do Tempo utilizado nesta pesquisa referiu-se a uma adaptação feita do instrumento criado por Amaral (2011), em que as professoras registraram três momentos de sua trajetória profissional que gostariam de reviver e outros três que, se pudessem, modificariam (APÊNDICE D). Em sua realização, a pesquisadora, primeiramente, conversou com as participantes a respeito de tais momentos. Depois, foram solicitadas a fazerem os registros escritos.

Entre os objetivos desse instrumento estavam à construção de indicadores a respeito dos núcleos subjetivos relacionados à experiência profissional das participantes, ao trabalho pedagógico propriamente, e aos processos de movimento subjetivo das professoras. Possibilitou às docentes relembrar situações e fatos ocorridos que poderiam ter sido significativos para sua expressão criativa, para movimentos subjetivos e produções subjetivas atuais provenientes do trabalho pedagógico. Para González Rey (2007b, p. 180):

\footnotetext{
A forma como o passado aparece para o sujeito não é uma memória concreta e pontual do que objetivamente ocorreu, mas um momento de produção de sentido subjetivo sobre aquela época de sua vida, por isso é que uma frase aparentemente ingênua associada à escola aparece, com muita frequência, como um indicador do sentido subjetivo de toda uma etapa da vida.
}

Com base nessa compreensão, realizamos o Túnel do Tempo antes da entrevista em que foi tratada a experiência profissional dos participantes.

\section{Redação}

A redação, por se caracterizar como um instrumento escrito, permitiu às participantes da pesquisa refletir e (re) estruturar suas experiências em forma de texto e, assim, produzir processos simbólicos e emocionais envolvidos com os temas solicitados (GONZÁLEZ REY, 2005b). Para González Rey (2005b), esse tipo de instrumento possibilita a produção de trechos de informações pelos próprios participantes da pesquisa, com independência de perguntas feitas pelo pesquisador. 
Além disso, o autor destaca a elaboração pessoal por parte dos participantes, o que lhe confere distinções entre aquelas redações produzidas de maneira formal das que implicam a reflexão e as emoções dos que a escrevem. Para ele, “[...] nas redações, o sujeito está obrigado a construir uma narração portadora de uma qualidade que está além de sua intencionalidade e de seu controle.” (GONZÁLEZ REY, 2005b, p. 62).

Nessa perspectiva, foram propostas duas redações durante a pesquisa, que tiveram como temas: O Sentido da Minha Vida (realizada antes da entrevista sobre a trajetória de vida) e O Sentido de Ser Professor (produzida antes da entrevista acerca da trajetória profissional). Buscamos, com isso, construir indicadores, em momentos diferentes do estudo, a respeito das relações entre a profissão e a realização pessoal das professoras participantes, dos principais núcleos subjetivos, assim como resgatar processos emocionais e simbólicos que participaram de movimentos na subjetividade das professoras.

\section{Completamento de frases}

O Completamento de Frases que foi utilizado nesta pesquisa referiu-se a uma adaptação feita do instrumento usado por González Rey e Mitjáns Martínez (1989). De caráter escrito, diz respeito a registros breves por parte dos participantes a respeito de indutores curtos apresentados em sequência. Estes se referem a atividades, pessoas ou experiências, sobre os quais os participantes se expressam (GONZÁLEZ REY, 2007b).

$\mathrm{Na}$ pesquisa, foi relevante a consideração dos registros em seu conjunto, pois representam trechos de informações que permitem o processo construtivo-interpretativo de sentidos subjetivos diversos. De fato, para González Rey (2005b, p. 59) o completamento de frases é "[...] uma rica fonte de indicadores e seu valor como instrumento está na possibilidade de elaborar um sistema de hipóteses que se integram e marcam o curso da produção de informação".

No estudo, esse instrumento teve por objetivo "consolidar" indicadores construídos acerca da subjetividade individual das participantes a partir dos demais instrumentos, aproximando-nos das relações entre as realizações profissionais e outros campos da vida das professoras. As adaptações realizadas em relação ao instrumento original foram a exclusão da frase de $\mathrm{N}^{\circ} 53$ e acréscimo das frases de $\mathrm{N}^{\circ} 18,29,47,73$ e 74 . O roteiro está presente no APÊNDICE E. 


\section{Resolução de situações do cotidiano educativo (instrumento escrito)}

Esse instrumento foi criado para esta pesquisa e teve por objetivo investigar uma possível posição criativa das professoras, bem como, os processos que configuravam sua criatividade. Nele foram apresentadas situações pedagógicas (APÊNDICE F) relacionadas ao cotidiano do professor de educação infantil e anos iniciais do ensino fundamental, de acordo com a atuação da participante. Tais situações tiveram, como elemento comum, o processo de aprendizagem e questionamentos acerca do possível posicionamento docente diante das demandas apresentadas por estudantes fictícios.

\section{Duas grandes premiações}

Esse instrumento também foi criado para esta pesquisa e se caracteriza como um pequeno questionário que envolvia, inicialmente, a indicação das professoras de duas experiências pedagógicas que ocorreram ao longo de sua carreira e que julgavam ser merecedoras de premiação (APÊNDICE G). Tais experiências poderiam se referir a atividades ou projetos realizados. Posteriormente, as professoras responderam às questões indicadas, o mais detalhadamente possível. Tivemos como objetivo construir indicadores acerca de experiências significativas para a constituição da criatividade no trabalho pedagógico e da forma como elas podem ter impactado o movimento na subjetividade das professoras.

A ordem de realização dos instrumentos ocorreu segundo as características das participantes do estudo de casos, sendo, em algumas situações, modificadas as solicitações quanto às escritas. Procuramos, com isso, respeitar as peculiaridades de cada uma delas (aquelas que se sentiam à vontade em escrever, ou em falar), as dinâmicas dos horários das professoras, as demandas das instituições educativas e dos cursos que algumas delas realizavam. Ressaltamos, ainda, que apesar de indicarmos objetivos específicos para cada instrumento, as informações construídas foram além do proposto inicialmente, o que enriqueceu o processo de estudo e permitiu avançarmos nas construções que realizávamos a respeito do modelo teórico em andamento. A propósito, destacamos a seguir os aspectos que permearam tais construções. 


\subsection{A proposta para a construção das informações}

Os princípios da Epistemologia Qualitativa e a forma como ela compreende a elaboração e utilização dos instrumentos de pesquisa conduzem a um olhar diferenciado a respeito da legitimidade do conhecimento. Esse princípio rompe definitivamente com a crença em sua força e cientificidade nos parâmetros positivistas e inaugura um campo em que os critérios científicos são pautados na possibilidade de inteligibilidade e construção de novas zonas de sentido em relação à realidade.

Para González Rey (GONZÁLEZ REY, 2005b, p. 6), as zonas de sentido se referem aos “[...] espaços de inteligibilidade que se produzem na pesquisa científica e que não esgotam a questão que significam, senão que pelo contrário, abrem a possibilidade de seguir aprofundando um campo de construção teórica.”. Disso decorre um dos aspectos centrais da Epistemologia Qualitativa: a maneira diferenciada que define o conhecimento e o seu processo de produção.

Nessa perspectiva epistemológica, o conhecimento é compreendido como forma de construção teórica; nela as categorias e explicações disponíveis são temporais e se caracterizam como expressões parciais, mas que permitem avançar na produção contínua de conhecimento (GONZÁLEZ REY, 1997). Por isso, fazer ciência, para o autor, é manter o desafio de desenvolver nossos pensamentos acerca do modelo teórico em construção, o que possibilita significar aspectos diferentes do problema estudado (GONZÁLEZ REY, 2005b).

A esse respeito, ressaltamos a construção do modelo teórico, o qual é compreendido como produção teórica em processo que se constituí no curso da pesquisa. É inseparável da posição ativa e produtiva do pesquisador. As ideias vão se integrando em um tecido dinâmico articulado pela reflexão do pesquisador, formando-se um sistema que se desenvolve a partir da tensão permanente entre a sua produção intelectual e o momento empírico (GONZÁLEZ REY, 2005b). Refere-se, portanto, às hipóteses teóricas inter-relacionadas e em desenvolvimento, um sistema hipotético em andamento que busca integrar os sentidos subjetivos na organização mais complexa das configurações subjetivas (GONZÁLEZ REY, 2011b).

A compreensão do modelo teórico como um sistema em processo conduz ao entendimento de que a legitimidade do conhecimento ocorre quando:

Uma teoria pode avançar na construção teórica do que estuda, conservando sua continuidade e congruência. Entendemos por continuidade a capacidade da teoria para integrar em seus termos atuais novas áreas de sentido sobre o estudado, e, como congruência, a possibilidade de enfrentar momentos de ruptura conservando sua 
integridade como teoria, isto é, sua capacidade para assimilar construções novas sem perder sua integridade (GONZÁLEZ REY, 2005b, p. 134-135, grifo nosso).

Nessa perspectiva, o conhecimento é visto como produção, um processo vivo e não apropriação linear de uma realidade, o que evidencia o papel do pesquisador no curso da pesquisa e construção do conhecimento. Este, para González Rey (2002, 2005b), se converte em núcleo gerador de pensamentos, parte inseparável da pesquisa, ele próprio é sujeito e teórico da pesquisa.

Para Neubern (2005), o pesquisador tem a possibilidade de, no processo interativo e dialógico da pesquisa, reconhecer a especificidade das significações e sentidos dos participantes da pesquisa, operando de forma conjunta com os indivíduos nas reconstruções que emergem no andamento do processo de estudo. Além disso, é o pesquisador que, no decorrer do processo de pesquisa e no complexo universo de informações produzidas, ramifica as ideias em diversos eixos e núcleos de pesquisa, combinando simultaneamente processos de produção teórica e empírica e as suas construções do pensamento com os fatos da realidade estudada (GONZÁLEZ REY, 2002, 2005b).

Essa combinação não segue uma lógica rígida e linear, ao contrário, para González Rey (1997, 2002, 2005b), ela é uma Lógica Configuracional, que, em síntese, envolve a compreensão do pesquisador em um processo complexo, ativo, plurideterminado e permanente de produção de ideias e reflexões, as quais não são organizadas por nenhum critério externo, mas pela produção de núcleos geradores de sentido e pela construção de indicadores no curso da pesquisa.

O indicador representa, assim, um momento hipotético no processo de produção de informações, é uma “[...] construção capaz de gerar um significado pela relação que o pesquisador estabelece entre um conjunto de elementos que, no contexto do sujeito estudado, permitem formular uma hipótese.” (GONZÁLEZ REY, 2002, p. 113). Refere-se a um momento explicativo, interpretativo, irredutível às informações explícitas advindas dos instrumentos utilizados na pesquisa. Para González Rey (2002, 2005b), o indicador não possui uma relação direta com o conteúdo de nenhum dos elementos vistos em separado, ele só se constrói sobre a base de informações implícitas e indiretas que se constituem gradativamente por meio da expressão do participante da pesquisa. Não é um conjunto de categorias construídas a priori, mas categorias produzidas no processo construtivo e interpretativo da produção de conhecimentos.

Foram esses os aspectos epistemológicos e metodológicos que consideramos no curso desta pesquisa. A seguir, apresentamos as construções realizadas no estudo. 


\section{PROCESSO CONSTRUTIVO- INTERPRETATIVO REALIZADO NA PESQUISA: ESTUDO DE CASOS}

O estudo da subjetividade humana, segundo a perspectiva histórico-cultural, ocorre em meio ao processo fluido e dinâmico de produções subjetivas que se constituem para além da consciência dos sujeitos. Estudá-la requer, portanto, um cuidado minucioso do pesquisador, o confronto de ideias, a reflexão constante, um ir e vir nas informações; um movimento construído a partir da lógica configuracional. A construção das informações advindas de cada caso, assim, não segue padrões, modelos fechados em si mesmos, ao contrário, contempla as especificidades de cada participante.

Nesse processo de pesquisa, os indicadores são construções interpretativas acerca das produções subjetivas de cada integrante do estudo. É por isso que destacamos a interpretação gradativa de cada caso em particular, tendo clareza que não esgotamos a organização subjetiva que integram os sentidos e os núcleos subjetivos das professoras. O que tentamos fazer aqui é, de fato, uma aproximação àqueles elementos subjetivos que construímos ao longo do estudo, os quais nos permitem compreender processos subjetivos que configuram a criatividade no trabalho pedagógico do professor e suas inter-relações com o movimento em sua subjetividade.

Ressaltamos que as análises apresentadas a seguir não abarcam todos os processos ou, mesmo, todos os elementos (históricos, culturais, subjetivos, dentre outros) que participam da criatividade no trabalho pedagógico do professor. Expomos, no momento, o nosso processo construtivo-interpretativo em cada caso, na tentativa de avançar na construção de conhecimentos que integram o tema investigado.

Para tanto, organizamos as construções realizadas em algumas seções, que buscam nos aproximar de respostas (mesmo que parciais) relacionadas aos objetivos específicos propostos nesta pesquisa. Fazemos, inicialmente, uma apresentação dos participantes, evidenciando as informações que julgamos serem relevantes para as construções seguintes. Prosseguimos com algumas informações de cada instituição, para, então, adentrarmos nas questões relacionadas a seguir:

a) expressões criativas no trabalho pedagógico de cada participante: momento em que indicamos a criatividade no trabalho pedagógico, ou seja, aqueles aspectos da dinâmica educativa que representam novidades com valor para os processos de aprendizagem e desenvolvimento dos estudantes, bem como para o funcionamento 
psicológico das docentes. Nessa discussão, nos aproximamos do clima comunicativoemocional da sala de aula de cada professora da pesquisa;

b) a subjetividade individual das professoras: seção em que privilegiamos os processos construtivo-interpretativos no que se refere ao exercício da condição de sujeito das participantes e aos principais núcleos subjetivos que participavam de sua criatividade no trabalho pedagógico;

c) os processos de movimento na subjetividade individual das professoras participantes: trecho em que apresentamos as construções a respeito dos processos de movimento subjetivo relacionado ao trabalho pedagógico criativo de cada docente.

Apresentamos as seções que compõe o estudo de casos tendo clareza que, em muitos momentos, integramos os diferentes assuntos, fazendo construções e referências que articulam tais informações, mas sabendo também que as seções em si não encerram as discussões, não esgotam o assunto em pauta. Entendemos que esse processo decorre da própria complexidade do tema, das peculiaridades do estudo da criatividade como processo complexo da subjetividade humana na perspectiva histórico-cultural.

No processo construtivo-interpretativo exposto em cada caso, indicamos alguns aspectos teóricos, procurando favorecer um diálogo com as bases teóricas desta pesquisa. Após a apresentação das construções realizadas, apresentaremos a análise integrativa dos casos, momento em que evidenciaremos a produção teórica do presente estudo.

\subsection{O caso da professora Ananda}

\subsubsection{Quem é a professora Ananda? Onde atua? Informações iniciais}

A professora Ananda nasceu em Brasília, possuía quarenta e dois anos de idade no momento da pesquisa. Mãe de três filhos (dois adultos e um adolescente), separou-se de seu segundo marido no mês anterior ao início da pesquisa. No período do estudo, morava apenas com seu filho caçula, os dois mais velhos estavam casados e cada um tinha um filho.

Fez o curso de Magistério e, no último ano do ensino médio, ficou grávida, casou e se mudou para uma cidade no interior do Brasil, onde iniciou a graduação em Pedagogia. Finalizou esse curso na Universidade de Brasília, quando voltou a morar nessa cidade. Começou a atuar como professora aos dezoito anos de idade em instituições privadas, nas 
quais permaneceu por dezoito anos. Trabalhava na Secretaria de Estado de Educação do Distrito Federal - SEDF - desde 2000.

Em sua trajetória profissional, atuou também como coordenadora articuladora, função em que trabalhava com formação continuada e acompanhamento do trabalho pedagógico desenvolvido em turmas do Bloco Inicial de Alfabetização (três primeiros anos do ensino fundamental). E ainda, como membro da equipe de direção de uma instituição educativa.

Foi para a instituição educativa onde ocorreu a pesquisa em 2009 e lá atuou como coordenadora pedagógica e professora até o ano letivo de 2013. No período do estudo, Ananda estava atuando como professora do quinto ano do ensino fundamental, turno matutino, tendo, em sua turma, em torno de trinta estudantes, que tinham, em média, dez anos de idade.

\subsubsection{Contexto da instituição educativa onde Ananda atuava}

A instituição educativa onde Ananda atuava atendia exclusivamente aos anos iniciais do ensino fundamental, localizava-se na área central de Brasília e recebia alunos de diferentes regiões administrativas. Sua estrutura física estava em bom estado de conservação, os espaços estavam pintados e higienizados. Havia salas de aulas bem iluminadas, equipadas com um ventilador de teto, um aparelho de som, armários para os professores, estantes e armários pequenos para guardar materiais didáticos, e as carteiras estavam de acordo com as faixas etárias atendidas.

O ensino organiza-se em ciclo: o Bloco Inicial de Alfabetização, que compreendia os três primeiros anos do ensino fundamental, em que a retenção só poderia ocorrer no terceiro ano. E seriação, que envolvia o quarto e quinto ano, conforme disposição implementada pela SEDF. No ano letivo de 2013, Ananda era a única professora de quinto ano do turno matutino, e a ela cabia o planejamento e organização do trabalho pedagógico a ser desenvolvido com sua turma.

$\mathrm{Na}$ instituição educativa, os professores atuavam em um turno em regência e outro em coordenação pedagógica, sendo um dia destinado à reunião coletiva, em que se discutiam assuntos mais administrativos; outro, para planejamento do trabalho pedagógico; e, um terceiro período, para a formação em serviço (os profissionais interessados em realizar cursos oferecidos pela Escola de Aperfeiçoamento dos Profissionais da Educação se dirigiam ao 
local; caso contrário, permaneciam na instituição educativa para planejamento ou demais atividades). Nos outros dois dias, os professores ficavam em coordenação pedagógica externa.

Como características gerais, observamos que os profissionais que atuavam nessa instituição realizavam, intencionalmente, um trabalho pedagógico diferenciado com as áreas de literatura e matemática. $\mathrm{Na}$ área de literatura, exemplificamos essa afirmativa com o trabalho desenvolvido na biblioteca, lá havia uma professora que desenvolvia ações sistematizadas e planejadas, que abrangiam, a leitura oral e a recitação de diversos gêneros textuais, o conhecimento da vida e obra de diferentes autores e atividades voltadas para a apreciação literária. Em matemática, foi relatado pela coordenadora pedagógica, mestre em educação matemática, que durante oito anos um professor universitário dessa área realizou atividades específicas envolvendo assuntos matemáticos, encaminhou discussões junto aos professores e indicou estagiários em Pedagogia para a realização de observações na instituição, que conduziriam aos relatórios e às monografias de final de curso. Havia, com isso, a realização de diferentes atividades relacionadas à educação matemática, como a poupança coletiva, em que os estudantes guardavam moedas, em um cofre, durante todo o ano letivo e, no final do período, escolhiam como gastar o montante (passeio, comemoração, etc.).

Foi nesse contexto que estudamos a criatividade no trabalho pedagógico da professora Ananda, que, dentre as características gerais, favoreceu em sua turma a participação ativa dos estudantes, sua implicação com a aprendizagem e o seu envolvimento nas atividades desenvolvidas, como será apresentado a seguir.

\subsubsection{Os instrumentos da pesquisa com a professora Ananda}

Quadro 9 - Os instrumentos da pesquisa com a professora Ananda

\begin{tabular}{||l||l||}
\hline \multicolumn{1}{|c|}{ Instrumentos e procedimentos da pesquisa } & \multicolumn{1}{|c||}{ Data } \\
\hline \hline Cenário de pesquisa & Fevereiro/2013 \\
\hline Observações no cotidiano escolar e conversas informais & $\begin{array}{l}\text { Abril/2013 a } \\
\text { Agosto/2013 }\end{array}$ \\
\hline Redação 1: O sentido da minha vida & Abril/2013 \\
\hline Entrevista 1: Trajetória de vida, pessoal e acadêmica & Abril/2013 \\
\hline Túnel do tempo & Junho/2013 \\
\hline Completamento de frases & Junho/2013 \\
\hline Redação 2: O sentido de ser professor & Agosto/2013 \\
\hline Entrevista 2: Trajetória profissional & Julho/2013 \\
\hline $\begin{array}{l}\text { Análise documental: atividades educativas, avaliações da aprendizagem , } \\
\text { cartazes, texto escrito por Ananda (poema para sua neta). }\end{array}$ & $\begin{array}{l}\text { Durante } \\
\text { observações }\end{array}$ \\
\hline Duas grandes premiações & Setembro/2013 \\
\hline Entrevista 3: esclarecimento de informações & Setembro/2013 \\
\hline
\end{tabular}

Fonte: a autora (2014). 
4.1.4 Expressões criativas no trabalho pedagógico: a professora Ananda como sujeito de sua prática profissional

Em nossa pesquisa, compreendemos que a criatividade no trabalho pedagógico ocorre em contexto, é situada em um espaço-tempo que permite a definição da expressão criativa nos diferentes momentos e práticas que compõem o trabalho pedagógico. No caso da professora Ananda, destacamos sua criatividade no trabalho pedagógico, especialmente:

a) nas relações professor-aluno e c clima comunicativo-emocional, em que consideramos as relações personalizadas construídas entre os integrantes da dinâmica educativa, o que favorecia os processos de aprendizagem e desenvolvimento dos estudantes;

b) na organização do processo de ensino-aprendizagem, em que valorizava o pensamento, a reflexão e a autoria por parte dos alunos em seu processo de aprendizagem;

c) na formulação e seleção dos objetivos de aprendizagem, em que ampliava o trabalho pedagógico para além do acesso ao conhecimento, aos conteúdos factuais, incluía como objetivos: o desenvolvimento do respeito ao outro e a inclusão de questões sociais, em sintonia com outros conteúdos previstos no currículo da instituição;

d) nas estratégias e métodos de ensino, com a elaboração de atividades educativas próprias, articuladas à formulação e seleção dos objetivos de aprendizagem.

Ressaltamos que os aspectos elencados acima se articulam mutuamente e, em conjunto com outras práticas educativas desenvolvidas por Ananda, compõem um trabalho pedagógico criativo e sistêmico. Trataremos tais aspectos de modo específico, na tentativa de evidenciar a criatividade da professora em seu trabalho pedagógico.

Dentre os momentos de expressão criativa no trabalho pedagógico de Ananda, consideramos as relações personalizadas construídas entre a professora e os seus alunos. Nos dias de observação na instituição educativa, Ananda conversou em alguns momentos com a pesquisadora acerca da história de vida de alguns estudantes, demonstrou conhecer situações específicas da trajetória escolar de muitos deles e de experiências significativas vivenciadas por eles em outros momentos e espaços sociais.

A situação a respeito do aluno Alex pode exemplificar nossa afirmativa. Percebemos, no curso das observações, que Ananda solicitou, em diversas situações, a colaboração desse 
aluno para a realização de certas tarefas, como o seu auxílio aos demais estudantes no laboratório de informática, ajudando-os a salvar em pen drive os arquivos referentes a um texto produzido por eles para o dia das mães.

Em outro momento, a professora nos contou que esse estudante possuía certa resistência às propostas educativas da instituição. Em anos anteriores, Alex foi visto pelo grupo de professores como um aluno "difícil", que reclamava das atividades propostas, resmungava e, por vezes, fazia referências ao fato de sua mãe ser professora, desprestigiando os conhecimentos de seus professores. Ananda, diante da situação, comentou que desde o início do ano letivo buscou construir uma relação de "parceria" com ele, solicitando sua ajuda para a realização das atividades sugeridas por ela, de modo que se sentisse importante dentro da dinâmica educativa da sala de aula.

No processo construtivo-interpretativo, compreendemos que essas solicitações de auxilio a Alex eram expressões de uma relação personalizada da professora com o aluno. Diante de comportamentos anteriores, Ananda dirigiu-se, intencionalmente, para o estabelecimento de uma relação diferenciada com ele, procurando incluí-lo nas atividades para além da sua execução, como uma forma de Alex sentir-se integrado às ações educativas desenvolvidas. Essa mobilização foi possível porque a professora estava atenta aos seus estudantes, conhecia-os de modo particular, havia uma relação personalizada com cada um deles.

Interpretamos que os relatos da professora acerca de seus alunos não representaram justificativas para tratamentos de exclusão, ao contrário, foram compreendidos como um interesse de Ananda por conhecê-los e auxiliá-los em seu desenvolvimento. Essa construção converge para as afirmações de Tacca (2004, p.110), quando a autora afirma que para o "professor inclinado a ir ao encontro de seus alunos, confirmando-os como pessoas, interessa obter um conhecimento íntimo destes, valorizando-os e aceitando-os como pessoas, o que antecede a escolha dos modos de intervenção [...].”. Ananda, com base nessas informações sobre seus alunos, procurava oferecer uma atuação pedagógica diferenciada, segundo as necessidades educativas que apresentavam.

Consideramos que essa seria a maneira "esperada" de relação entre professores e alunos nos espaços escolares. Entretanto, atribuímos criatividade às relações que Ananda construiu com seus alunos, exatamente, por entendermos que, a partir delas, a professora voltava-se para a elaboração e realização de ações educativas que modificassem situações anteriores, julgadas como desfavorecedoras da interação entre eles. Isto é, buscava oferecer situações 
educativas novas e com valor para os processos de aprendizagem e desenvolvimento de seus estudantes.

Esse movimento intencional de Ananda era possível no interjogo das produções subjetivas que se formavam no curso das relações entre professora e alunos, a partir das quais se constituíam sentidos subjetivos que repercutiam na atualização daquelas configurações subjetivas relacionadas ao trabalho pedagógico da professora, bem como em seu interesse pela atuação docente. Essa produção subjetiva pode ser identificada com base tanto nessa implicação da professora para propor atividades diferenciadas, de acordo com as especificidades dos alunos, como no entusiasmo que expressava durante as aulas, nos sorrisos de Ananda com as falas, as participações dos estudantes, no seu esforço em produzir atividades educativas que apreciassem e se envolvessem.

Essa implicação foi observada durante muitas situações do trabalho pedagógico, mesmo que, em outros campos de sua vida, Ananda estivesse passando por momentos de mudanças, como no período em que estava separando-se do segundo marido (o que ocorreu no início da pesquisa). Nessa situação, Ananda reconheceu o seu sofrimento com o rompimento do relacionamento, afirmou que gostaria de "tentar mais". Além da sua afirmação, ao completar frases, a professora registrou:

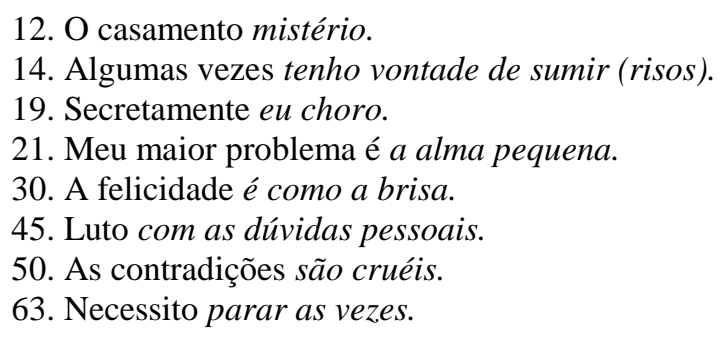

Interpretamos, a partir das informações, que a situação de sua separação pode ter gerado um desconforto emocional, caracterizado por certo sofrimento e conflito entre o que ela desejava, permanecer casada, e a decisão que o marido tomou. Ainda assim, ela se manteve ativa em seu trabalho pedagógico, produzindo as atividades educativas que desenvolveu com seus estudantes, sorrindo das construções que faziam durante as conversas, planejando suas aulas.

Tais aspectos podem estar vinculados a diferentes produções subjetivas, dentre elas, aos sentidos subjetivos que se constituíam no processo de elaboração e realização das atividades educativas propostas por ela, bem como das relações entre a professora e os alunos. Hipotetizamos que, esse processo e as relações com os estudantes favoreciam a constituição de sentidos subjetivos associados ao seu bem-estar emocional, a sua realização pessoal e 
profissional, os quais possibilitavam o protagonismo de Ananda em seu trabalho pedagógico, apesar de mudanças e sofrimentos vivenciados em outros campos de sua vida.

No curso das próprias experiências criativas desenvolvidas pela professora, consideramos que se constituíam sentidos subjetivos que oportunizavam sua criatividade no trabalho pedagógico. Ela se sentia bem no espaço escolar que constituiu com seus estudantes, divertia-se com as colocações que faziam durante as aulas. As atividades pedagógicas que propunha eram produções particulares que incluíam os objetivos de aprendizagem que traçava para eles, as necessidades educativas que identificava segundo as particularidades que demonstravam, como indicamos na situação relatada sobre o aluno chamado de Alex.

Esses aspectos se relacionam às afirmações de Mitjáns Martínez (2004, p. 92-93) quando coloca: “[...] a criatividade, entendida como ao processo de produção de novidades com valor, pode vir a se expressar a partir dos sentidos subjetivos produzidos na própria ação, sentidos que possam mobilizar configurações subjetivas facilitadoras da ação criativa." Com Ananda, compreendemos que o próprio trabalho pedagógico criativo lhe gerava esses sentidos subjetivos vinculados ao seu bem estar emocional, à sua realização pessoal e profissional, implicando, por sua vez, esse processo de produção de novidades com valor para o processo de aprendizagem de seus alunos. Isso relacionamos, ainda, a compreensão de que as produções subjetivas que se constituíam no trabalho pedagógico criativo tinham "valor" para o próprio funcionamento psicológico da professora.

Além disso, interpretamos que havia uma produção subjetiva também entre os alunos. Estes se mostravam satisfeitos, felizes e entusiasmados ao realizar as atividades educativas propostas, demonstravam interesse em relação aos assuntos em pauta. A sala de aula de Ananda caracterizava-se por sua participação ativa, pelos diálogos e troca de ideias entre eles, e deles com a professora. Essas situações decorriam, certamente, de uma produção subjetiva por parte dos estudantes, que se constituía nesse espaço de diálogo e respeito mútuo, produção de sentidos subjetivos que favorecia os processos de aprendizagem e desenvolvimento, implicando movimentos de superação, de esclarecimento de dúvidas, de construção de conhecimentos, mantendo-os ativos e seguros para perguntarem e exporem suas ideias, e com isso, avançar em sua aprendizagem.

Nessa perspectiva, consideramos o que afirma Tacca $(2004$, p. 110) a respeito da relação professor-aluno: “[...] a qualidade do mutuamente vivido na comunidade da sala de aula depende da extensão em que ficam criadas as condições que possibilitam a relação fundada no diálogo e no encontro [...]". No caso de Ananda, observamos o seu papel para a 
constituição desses aspectos, o que lhe possibilitava, como afirma a citada autora (2004, p. 110), “[...] organizar o ambiente social de forma a possibilitar condições para a vivência de momentos de intimidade, criando oportunidades para os processos de desenvolvimento.".

Nesse espaço de diálogo, havia a valorização dessa participação dos alunos, a professora instigava as suas colocações e reflexões, como iremos aprofundar, de forma mais específica, em outro tópico. De modo ativo, Ananda mobilizava-se para "fazer coisas diferentes", em outras palavras, "deixar marcas", como afirma De La Torre (2006). Ao falar sobre suas experiências profissionais, afirmou: "Eu penso que eu tenho que ser diferente. Eu tenho isso dentro de mim. Eu não sou a mais bonita, nem a mais rica, mas eu tenho que ser a mais especial na vida dos meus alunos. Então, eu gosto de fazer coisas diferentes com eles" (Ananda, Túnel do tempo, grifo nosso).

$\mathrm{Na}$ busca por ser "mais especial", a professora se empenhava na produção de novidades com valor para a aprendizagem e desenvolvimento dos estudantes, o que implicava um movimento intencional para a criação. Essa implicação consciente para a criação foi identificada por Mitjáns Martínez (2003a) em profissionais criativos, e nos permitiu hipotetizar o forte significado da profissão para a professora, bem como das produções subjetivas que se constituíam no curso do trabalho pedagógico.

Interpretamos que a produção subjetiva gerada a partir das relações sociais entre Ananda e seus alunos implicava a constituição de sentidos subjetivos que participavam da sua criatividade no trabalho pedagógico, mobilizando-a para a produção de novidades com valor para os processos de aprendizagem de seus estudantes. A respeito dessa relação, ela registrou: "meus alunos são sempre os mais especiais e queridos, por eles pinto e bordo, estudo, pesquiso, crio, invento e dou o que há de mais sincero e verdadeiro" (Ananda, Redação I). O conjunto de informações da pesquisa nos possibilitou compreender que havia o apreço da professora por seus estudantes e uma mobilização consciente para favorecer a aprendizagem deles, o que relacionamos, ainda, ao papel das relações sociais para a expressão criativa de Ananda.

Para a professora era importante que seus alunos guardassem na lembrança momentos vivenciados junto com ela. Em conversa informal, ela relatou que gostava de atuar no quinto ano do ensino fundamental porque era a partir dali que os estudantes guardavam as recordações mais vivas dos primeiros anos de escolaridade, e queria que eles se lembrassem de situações que viveram juntos. Ananda demonstrava que lhe agradava a continuidade dessas relações para além do espaço escolar. Com emoção e indicativos de carinho, relatou que 
mantinha contatos com alguns ex-alunos por diversos meios de comunicação, como telefone e rede sociais. Em suas palavras, declarou: "os vinte alunos com quem eu tenho contato, são tão queridos, é uma relação tão boa, uma relação tão gostosa! De um carinho e de uma amizade tão grandes! Fico tão satisfeita, tão feliz!” (Ananda, Túnel do tempo).

Reconhecemos, assim, que nas relações personalizadas que Ananda estabelecia com seus alunos se constituíam sentidos subjetivos, que faziam dos estudantes um outro social significativo para o seu desenvolvimento, como nos afirma González Rey (2004). Para o autor (GONZÁLEZ REY, 2004, p. 22), “[...] o outro tem significação para o desenvolvimento só quando o sujeito consegue um relacionamento com esse outro, carregado de sentido". Entendemos que esse relacionamento era estabelecido no decorrer do ano letivo e integrava momentos e experiências anteriores ao contexto atual (GONZÁLEZ REY, 2011b), possibilitando a formação de uma rede de sentidos subjetivos (GONZÁLEZ REY, 2012) que participavam do trabalho pedagógico de Ananda.

Consideramos que os sentidos subjetivos produzidos nessas relações formavam um núcleo subjetivo, que será discutido posteriormente, o qual integrava a expressão criativa da professora, evidenciando o que Mitjáns Martínez (2004) afirmou acerca da participação do social para a criatividade: as relações com o outro social podem gerar condições para a expressão criativa. Situação que compreendemos estar relacionada aos vínculos afetivos que se constituíam entre a professora e alunos, e às configurações subjetivas que se formaram na relação histórica com cada um deles.

No bojo dessas relações históricas e atuais entre Ananda e seus alunos, formavam-se certas necessidades educativas, como no caso de Alex, que implicavam sua criatividade no trabalho pedagógico. Isto é, a produção subjetiva que emergia desse sistema relacional com os estudantes gerava em Ananda sentidos subjetivos vinculados ao seu compromisso profissional, ao intuito de colaborar para a ampliação das possibilidades de aprendizagem, os quais favoreciam a produção de novidades com valor para os processos de aprendizagem e desenvolvimento dos alunos, atualizando também o núcleo subjetivo relacionado ao trabalho pedagógico e o seu interesse pela docência.

Em prol do intuito de favorecer a aprendizagem e desenvolvimento de seus alunos, a professora se empenhava na produção de atividades educativas que fossem significativas para eles, que possibilitassem a construção de conhecimentos e de reflexões próprias, de inferências de informações, como a produção de dramatizações acerca de assuntos trabalhados e produções de textos de diversos temas. Ao discorrer sobre suas experiências 
profissionais, afirmou: “Quero dar o melhor pra eles, sempre, sempre!” (Ananda, Túnel do tempo).

$\mathrm{Na}$ busca por esse "melhor", Ananda privilegiava atividades que requeriam o pensamento, a reflexão e a autoria por parte dos alunos em seu processo de aprendizagem, o que caracterizava a organização do processo de ensino-aprendizagem que se constituiu naquele ano letivo. Para tanto, as atividades educativas realizadas em sala de aula eram criações suas. Mesmo aquelas poucas tarefas que foram mimeografadas tinham sido elaboradas por ela, relacionando-se aos assuntos em pauta e aos objetivos de aprendizagem propostos pela professora.

No curso da pesquisa, observamos que as atividades educativas propostas por ela tinham caráter produtivo. Nelas os estudantes eram solicitados constantemente a pensarem, irem além das informações explícitas nos textos, a tentarem solucionar situações problema a partir de ideias próprias. Em geral, a professora partia do estudo de um tema e, com base nele, elaborava atividades que explorassem as diferentes áreas do conhecimento. Por isso, o pouco uso do livro didático.

Exemplificamos tais construções com a atividade em comemoração ao dia das mães, uma situação, dentre outras, que observamos no curso da pesquisa. Nessa situação, em especial, Ananda selecionou um livro "Ideias que Contam Histórias, Histórias das ideias do Zé", fez a leitura oral para os alunos e no dia seguinte retomou o enredo. Explicou que fariam a atividade a partir de suas próprias ideias a respeito de suas mães, contariam histórias de cada uma delas. A fim de exemplificar, contou para os estudantes algumas experiências vividas por ela, como macarronadas aos domingos e encontros entre irmãos para almoço em família.

Junto ao texto, explicou que eles entregariam um desenho, no qual seriam fixados imãs de geladeiras. Mostrou vários imãs e disse que, desde o início do ano, os estava recolhendo para essa atividade em homenagem às mães. Os alunos, à medida que faziam os seus textos, mostravam para a professora, que os corrigia apontando a utilização do dicionário para verificar o significado de algumas palavras e expressões.

Em outro dia, coletivamente, corrigiram uma atividade realizada em casa que abordava o enredo do livro. Nessa atividade, havia a solicitação de avaliação feita pelos pais a respeito da leitura oral do resumo da história, questões de interpretação de texto, o que incluía interpretação indireta, produção de um pequeno texto por parte dos alunos, inferências e relações com suas próprias histórias. Nessas atividades, percebemos que Ananda articulou uma data comemorativa à possibilidade de produção de textos por parte dos alunos, ao relato 
de histórias e de ideias a respeito das mães. Além disso, utilizou a atividade para tratar outros conteúdos previstos no currículo da instituição. Essas atividades foram pensadas, planejadas pela professora, que as elaborou para abordar os aspectos, os conteúdos selecionados.

Ao ser questionada acerca do planejamento de ensino, ela relatou que sentava para pensar, esquematizar, escrever o que iria fazer com seus alunos. Guardava alguns cadernos de planejamento, mas disse que não conseguia copiar a atividade como foi realizada antes, inspirava-se nela e criava outras em função da realidade. Afirmou: "Não me contento com algumas mesmices, não me contento!” (Ananda, Túnel do tempo). Quando sentava para planejar é porque as ideias já estavam "fervilhando em sua mente". A respeito desse processo de pensamento e de planejamento das atividades educativas, afirmou ainda:

\footnotetext{
O pensamento me incomoda, enquanto não sento para escrever eu fico só pensando. As ideias vêm, elas vêm. Eu não fico pensando, por exemplo, nessa imagem. Eu olho pra gravura e falo já sei: eu vou fazer isso, isso e isso. Dessa primeira ideia começo a ter mil e uma ideias, elas vão vindo, vão chegando, elas vão entrando na minha cabeça, é uma coisa de louco! (Ananda, Túnel do tempo).
}

Interpretamos essa produção de ideias no processo de elaboração das atividades como um indicador de que a professora se envolvia de maneira diferenciada em tal tarefa, que havia uma produção de sentidos subjetivos que participavam de sua criatividade, e que se vinculavam ao prazer de ensinar, ao seu bem-estar e sua satisfação pessoal com o trabalho pedagógico. Consideramos que esses sentidos subjetivos se relacionavam ao núcleo subjetivo que se formava em torno do trabalho pedagógico, mobilizando-a para a produção de novidades com valor para os processos de aprendizagem e desenvolvimento dos alunos. Assim, de forma consciente, a professora buscava a articulação entre objetivos de aprendizagem formulados e a produção de novidades no trabalho pedagógico, momento em que, intencionalmente, Ananda se implicava para a criação.

Nesse planejamento, participavam suas ideias, sua produção própria das atividades a serem realizadas pelos estudantes, a imaginação como processo subjetivo. Naquele trecho, ela afirmou: "Eu olho pra gravura e falo já sei: eu vou fazer isso, isso e isso.", o que nos permite entender o papel da imaginação para a criatividade de Ananda em seu trabalho pedagógico, antecedendo à realização das práticas educativas propostas por ela, como um processo concomitante à elaboração e produção das atividades que formulava. As ideias aqui foram entendidas, como afirma González Rey (2014), como produções subjetivas, atos de imaginação envolvidos por um propósito mais abrangente; no caso, facilitar a aprendizagem dos alunos. 
Para o citado autor (GONZÁLEZ REY, 2014, p. 47), as ideias não são apenas significados, uma expressão lógica do pensamento como operação cognitiva, ao contrário,“[...] elas serão portadoras de sentidos subjetivos que expressam a configuração subjetiva do sujeito implicado nessa operação, o que leva a que essa construção seja também uma produção dos valores pessoais frente a um tema.". No caso de Ananda, entendemos que as ideias que produzia no processo de planejamento de suas atividades educativas envolviam sentidos subjetivos que integravam os núcleos subjetivos relacionados à profissão - ser professora, ao trabalho pedagógico e àquele que se formavam a partir das relações com os alunos, bem como ao seu intuito de favorecer a aprendizagem e o desenvolvimento deles, o que se constituía como um forte valor para ela.

Nesse processo imaginativo de planejamento e produção de ideias, compreendemos que perpassavam também os conhecimentos científicos que Ananda teve acesso ao longo de sua trajetória profissional, seja por meio de sua formação inicial ou formação em serviço. No decorrer da pesquisa, consideramos que a professora foi criativa em momentos que estavam vinculados a uma formação específica, em áreas que lhe despertavam um interesse particular, como: literatura, educação matemática, filosofia e arte. Nas informações discutidas, há situações mais voltadas para a leitura, produção de textos, resolução de situações problemas, a proposta de autoria dos estudantes por meio de pensamentos, reflexões e registros de suas ideias, e a releitura de obras artísticas, como nos dias antecedentes à festa junina, produção de quadros para exposição na instituição, dentre outras situações.

Desses momentos participavam conhecimentos específicos, os quais foram subjetivados por Ananda num processo que articulava as informações que teve acesso em cursos de formação em serviço e em suas experiências de vida. Estes conhecimentos orientavam suas escolhas e o seu processo de elaboração das atividades educativas, eram mobilizados em seu trabalho pedagógico e se relacionavam a áreas específicas. Estas despertavam nela um apreço particular, havia um interesse pessoal específico, articulavam-se aos campos que lhe agradavam para além do trabalho pedagógico.

Ainda assim, em relação ao ensino superior, Ananda relatou que sua experiência foi "traumática", em decorrência do período que vivia: possuía uma filha pequena e durante o curso, teve seu segundo filho, já atuando como professora em instituições privadas. Tal situação, segundo a professora, não lhe permitiu "viver" essa formação, pois ela ia para faculdade assistir às aulas "com hora marcada para ir embora" (Ananda, entrevista I). Por 
isso, não percebia articulação entre os estudos realizados em sua graduação e sua prática profissional.

Depois, a partir de um processo de reflexão, Ananda disse que percebia uma relação entre esses estudos e sua prática profissional, no que se referia à busca por uma formação mais "holística" (suas palavras). Afirmou que na universidade havia essa preocupação, que buscava o ser integral e não uma formação apenas técnica. Pregava-se uma formação mais universal, aspecto que ela procurava realizar em sua prática, como compreendemos nas observações na instituição educativa. Mais à frente, será possível nos aproximarmos dessa formação inicial, a qual pode ter favorecido sua expressão criativa, em especial, ao lhe possibilitar ampliar o trabalho pedagógico para uma formação direcionada ao respeito ao outro e à inclusão de assuntos sociais.

Esse processo de reflexão por parte da professora junto à construção das informações nos possibilitaram o entendimento de que os conhecimentos mobilizados no curso da expressão criativa de Ananda se associavam aos processos de formação docente que participou. Esses conhecimentos se relacionavam, de forma mais expressiva, àqueles a que teve acesso nos cursos de formação em serviço. E mais, vinculavam-se a áreas específicas do conhecimento que lhe despertavam um interesse particular. Tais conhecimentos foram subjetivados no decorrer de sua formação e se articulavam a outros campos de interesse para Ananda.

Esse processo de subjetivação acerca dos conhecimentos científicos perpassava a formulação e seleção dos objetivos de aprendizagem, em que a professora, intencionalmente, ampliava o trabalho pedagógico para além do acesso ao conhecimento, aos conteúdos factuais. Incluía como objetivos: o desenvolvimento do respeito ao outro e a inclusão de questões sociais, em sintonia com outros conteúdos previstos no currículo da instituição.

Ananda empenhava-se em oferecer um trabalho pedagógico que favorecesse o pensamento dos estudantes. Citamos, como exemplo, a situação que a professora relatou a respeito do trabalho que desenvolveu acerca da Constituição Federal, o que fez de forma articulada às imagens de Sebastião Salgado, que retratava crianças trabalhadoras, e às notícias de jornais impressos. Nesse trabalho, os alunos verificavam as relações entre as notícias e os direitos presentes na Constituição, procurando, assim, estabelecer relações com a realidade.

Essa atenção aos acontecimentos sociais esteve presente na sua forma de selecionar os objetivos de aprendizagem e nos processos de elaboração das atividades educativas. Sua 
expressão criativa, nesse aspecto, estava nessa possibilidade de articulação entre os conteúdos previstos no currículo prescrito pela instituição e o intuito consciente da professora em permitir que os seus alunos refletissem sobre diferentes situações sociais. Tal relação foi possível devido ao interesse pessoal de Ananda por questões sociais. Ao completar frases, afirmou:

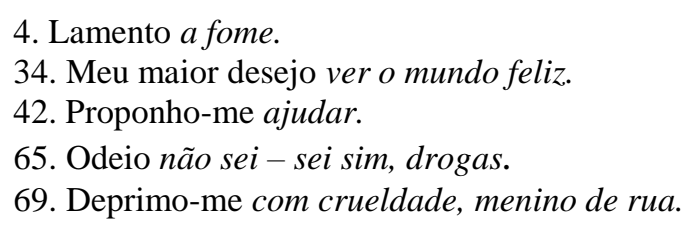

$\mathrm{Na}$ construção das informações, consideramos que a atenção às questões sociais pela professora gerava uma produção subjetiva que se integrava aos núcleos subjetivos que participavam do trabalho pedagógico, mobilizando-a a incluir de forma consciente e intencional processos de reflexão, por parte dos alunos, acerca de acontecimentos sociais. Isso evidencia que as emoções e os processos simbólicos que se organizavam no curso da experiência pedagógica não eram processos isolados, estavam em articulação às demais configurações subjetivas, como afirma González Rey (2012).

No caso de Ananda, consideramos, ainda, como essa articulação entre diferentes sentidos subjetivos, ao mesmo tempo atuais e históricos, geravam processos subjetivos, implicando a atualização de produções subjetivas que participavam da criatividade no trabalho pedagógico. A situação que nos relatou acerca de um aluno, Alexandre, nos permitiu construir indicadores a esse respeito.

Esse estudante, de acordo com a professora, era muito tímido, retraído, o que para Ananda, não lhe possibilitava uma boa autoestima, acreditar em si mesmo como pessoa capaz de superar obstáculos. Nesse ano letivo, escolheram para leitura o livro "Alexandre, o Grande”, em que o personagem principal tinha o nome desse aluno. A professora percebeu que ao fazerem a leitura oral, Alexandre ficava envergonhado. Ainda assim, passou a chamálo de Alexandre, o grande, como forma de ajudá-lo a superar sua timidez. No final do ano, ele não se incomodava mais com a forma que Ananda o chamava.

Anos depois, encontrou com o pai dele, que conhecia também como professor da rede pública de ensino. Ele comentou que Alexandre tinha passado no vestibular e lhe falou: “Ananda, você sabe que aquela sua brincadeira: Alexandre, o grande, mudou o Alexandre?". E comentou que o seu filho havia se transformado em Alexandre, o grande, a partir daquela forma com a qual Ananda o chamava, que isso, junto com outras experiências vividas, oportunizou mudanças em sua autoestima, e ele foi pouco a pouco se transformando. Para a 
professora, esse foi um retorno que julgou muito positivo e após esse comentário, chorou ao encontrar-se com esse ex-aluno.

Nesse relato, Ananda demonstrou forte emocionalidade e reflexão acerca de sua atuação docente, indicando a atualização de experiências anteriores que integravam, no momento do próprio relato, uma produção subjetiva que participava do núcleo subjetivo vinculado ao trabalho pedagógico. Essa produção subjetiva, aliada às relações com seus alunos, participava das ações educativas que a professora planejava, nas quais os objetivos de aprendizagem se ampliavam para o favorecimento do desenvolvimento de seus alunos.

Interpretamos que essa ampliação da ação docente para o desenvolvimento dos estudantes estava para além dos conteúdos prescritos no currículo da instituição, e era possível porque a professora incluía em seu trabalho pedagógico temas que ela mesma apreciava, favorecendo uma formação integral de seus alunos. Essa interpretação, por sua vez, nos conduziu à construção de uma hipótese a respeito da forma como função social da educação estava subjetivada para Ananda. Para ela:

\begin{abstract}
Sempre gostei de ensinar, mas nunca fiquei muito presa a ensinar só matemática, português, história, geografia, aprender a ler, aprender escrever. O meu objetivo não era esse. Acho que o meu objetivo sempre foi ensinar a viver, ensinar algumas coisas diferentes, que a criança não tivesse como base de formação mesmo, de personalidade, de caráter mesmo. É meio assim, né? Nossa! É... mas, de fato, a minha grande preocupação na profissão nunca foi só a matemática, português, geografia [...]. Pra mim isso sempre foi assim: eu tenho que ensinar isso, tranquilo! Mas eu queria ensinar para as crianças, sempre, o que é amizade, o que é respeito, o que é conviver em harmonia, o que é ser amigo de fato, ver a vida de outra maneira. (Ananda, Entrevista II).
\end{abstract}

Consideramos que este trecho exemplifica o intuito da professora em promover um processo de formação além do acesso aos conhecimentos científicos, ampliando o ensino para uma formação mais ampla, mais integral, que envolvia valores importantes para ela, como amizade e respeito. Entendemos que essa formação refere-se à maneira singularizada, a subjetivação acerca da função social da educação, que abrange processos simbólicos e emocionais acerca do papel da educação na sociedade.

Para Ananda a função social da educação estava subjetivada de tal forma que conduzia a práticas educativas criativas que tinham como propósito a formação integral dos alunos, o que estava para além do acesso aos conhecimentos científicos. Era preciso um trabalho pedagógico voltado para a formação humana, em que participavam a seleção diferenciada de objetivos de aprendizagem e a criatividade na elaboração de estratégias de ensino.

Para tanto, a professora implicava-se na produção de novidades com valor também em relação às estratégias e métodos de ensino, em que se voltava para a formulação de 
atividades próprias, articuladas à formulação e seleção dos objetivos de aprendizagem. Desse processo, participava a forma como Ananda subjetivava o papel, a forma como poderia ser o ensino, o que perpassava suas escolhas docentes e a instigava a utilizar diferentes recursos, estratégias pedagógicas e métodos de ensino.

Compreendemos, no período de observação, que a professora criava estratégias e métodos de ensino que favoreciam o posicionamento ativo dos estudantes, a proposição de problemas e sua resolução criativa, a construção de questionamentos e defesa de posições próprias. Para isso, ela utilizava recursos como folders, encartes de supermercado, panfletos, livros de histórias infantis e dinheiro (notas "reais" e imitações).

Em um dos momentos observados, vimos que, para trabalhar números decimais, a professora dividiu a turma em quartetos e distribuiu encartes de supermercado para cada um deles. Com o uso desse encarte e do quadro branco explicou como seria a atividade: compras individuais com valor livre e depois, compras em grupo com o valor de trezentos reais. Enquanto faziam a atividade individual, ela orientava e incentivava sua realização. Durante a tarefa, Ananda "simulava" situações do cotidiano, como: está na hora do almoço, a irmã está chorando, é preciso finalizar as compras. Os estudantes manuseavam notas de dinheiro de brinquedo, notas que compunham uma caixa individual com diferentes recursos e materiais de matemática. Ao final, a professora disse que escolheria alguns alunos para falarem a respeito de sua lista.

Nessa atividade com o uso do encarte, e muitas outras, eles tinham a oportunidade de ampliarem os seus conhecimentos por meio de relações entre os conteúdos previstos no currículo e situações reais, simuladas durante as atividades. Os alunos se envolviam, demonstravam alegria, conversavam entre si sobre o comando da atividade, empenhavam-se em fazer a atividade conforme as solicitações. De fato, na turma de Ananda, eram claros o interesse e a motivação dos estudantes para os processos de aprendizagem, percebemos tanto o envolvimento, como a satisfação, a alegria que sentiam em realizar as atividades propostas.

Hipotetizamos que a criatividade de Ananda no trabalho pedagógico favorecia a participação dos alunos em seu processo de aprendizagem e desenvolvimento, o que era possibilitado, certamente, pela produção de sentidos subjetivos que os mantinham ativos na construção do conhecimento. Essa produção subjetiva também implicava a ampliação da curiosidade por parte dos estudantes e da segurança emocional de se colocarem diante das situações-problema que a professora oferecia, como observamos em diversos momentos. Interpretamos que essa forma dos alunos se relacionarem com o seu processo de 
aprendizagem indicava o "valor" das práticas criativas de Ananda em seu trabalho pedagógico, o que incluía a aprendizagem propriamente e o interesse dos estudantes nesse processo.

Para tanto, colaborava o clima comunicativo-emocional que se constituiu no espaço da sala de aula. Ananda conversava com os alunos de forma tranquila e, em diferentes momentos, sorria das colocações que faziam em demonstração de apoio e carinho. Mesmo nos momentos em que chamava a atenção dos estudantes, utilizava-se de estratégias que indicavam respeito e interesse em favorecer sua reflexão.

Em uma das situações que acompanhamos, presenciamos uma aluna que, ao ouvir tocar o sinal para o intervalo, foi até a professora perguntar se ficaria sem recreio porque não tinha terminado a tarefa. Ananda chamou essa aluna e, de maneira tranquila, disse que fariam um "contrato de damas". Redigiu rapidamente um texto em que registrava o compromisso da estudante em terminar suas tarefas antes do recreio. Pediu que ela assinasse. Em clima de descontração e sorrindo, a aluna assinou o termo. No dia seguinte, a professora retomou o contrato que havia guardado em sua gaveta, conversando com a estudante acerca de suas tarefas. Nessa situação, consideramos a criatividade na elaboração de estratégias que possibilitavam o comprometimento da estudante com suas tarefas, oportunizando o seu envolvimento mais efetivo com sua atividade.

Essas estratégias que relatamos coadunam com o que Tacca (2006, p. 48) afirma acerca das estratégias pedagógicas. Para a autora, estas são recursos relacionais e pessoais que “[...] orientam o professor na criação de canais dialógicos, tendo em vista adentrar o pensamento do aluno, suas emoções, conhecendo as interligações impostas pela unidade cognição-afeto.”. O ensino, então, implica a atuação do professor com vistas a atingir a estrutura motivacional dos estudantes, o que se encontra unido aos processos de pensamento (TACCA, 2006).

No caso de Ananda compreendemos que ela desenvolvia um trabalho pedagógico que se direcionava para a dinamização das configurações motivacionais de seus alunos. Entendemos que esse aspecto, junto aos demais momentos do trabalho pedagógico que apresentamos acima, indicam uma organização sistêmica de ações educativas, de escolhas e posturas que representam, naquele espaço social e histórico, novidades com valor para os processos de aprendizagem e desenvolvimento dos alunos.

Nesse processo criativo, interpretamos que havia intencionalidade pedagógica, a professora tinha objetivos claros de aprendizagem que estavam para além as diretrizes curriculares e que mobilizavam o seu planejamento de ensino e seu trabalho pedagógico. Para 
alcançar tais objetivos, ela se empenhava para uma produção criativa, para a formulação de atividades diferentes, como denominou, e com valor para a aprendizagem e desenvolvimento dos estudantes.

Entendemos que esses processos de aprendizagem e desenvolvimento se expressavam por meio dos avanços que demonstravam na realização das atividades oferecidas, nas relações que estabeleciam entre os conteúdos tratados e outras experiências vividas por eles, nas falas, nas perguntas, nos textos produzidos e no entusiasmo que indicavam na realização das propostas educativas oferecidas por Ananda, aspecto esse que caracterizava a turma da professora.

Consideramos, assim, que as informações construídas no caso de Ananda nos evidenciaram que, naquele espaço social, a criatividade era um princípio funcional da aula, o que significa sua expressão nas principais ações e nas inter-relações que existiam naquele espaço educativo. Nesse processo de expressão criativa no trabalho pedagógico, constituíamse, em Ananda, produções subjetivas que atualizavam tanto o núcleo subjetivo vinculado às relações com os estudantes, quanto àqueles associados ao trabalho pedagógico e ao seu interesse para o exercício da docência.

No caso de Ananda, o processo construtivo-interpretativo favoreceu a compreensão de que a criatividade no trabalho pedagógico era, de fato, a expressão da dimensão funcional da criatividade. Ou seja, Ananda tinha um funcionamento psicológico que se caracterizava pelos processos de constituição e de reconstituição de configurações subjetivas, que geravam a possibilidade de assunção de alternativas autônomas e singulares de ação no enfrentamento das situações pessoalmente significativas (MITJÁNS MARTÍNEZ, 2009a), o que se manifestava em outros campos da vida da professora, e, em seu trabalho pedagógico.

Esse funcionamento criativo, aliado às produções subjetivas decorrentes do trabalho pedagógico, viabilizava a expressão instrumental da criatividade de Ananda em sua prática profissional. Isto é, havia na professora uma organização subjetiva caracterizada como criativa, por esta geração de alternativas singulares e autônomas. Por outro lado, a criatividade no trabalho pedagógico possibilitava a constituição de processos subjetivos que oportunizavam atualizações subjetivas, como bem-estar e satisfação com o seu trabalho, as quais favoreciam sua expressão criativa. Essa situação evidencia o valor da criatividade no trabalho pedagógico para a própria professora, para sua organização subjetiva, e não apenas para os processos de aprendizagem e desenvolvimento dos alunos. 
Dentre os elementos que nos permitiram compreender essa dimensão funcional da criatividade, estava a diversidade de interesses que a professora possuía, o trabalho pedagógico, a sua profissão, eram partes de um espectro mais amplo de experiências emocionais. Cozinhar, por exemplo, era uma atividade prazerosa para Ananda. Em diferentes momentos ela relatou receitas que havia feito, pratos produzidos para momentos em família e para os próprios alunos. Justificou a realização de oficinas culinárias, no projeto interventivo da instituição ${ }^{6}$, por sua habilidade na cozinha. Tinha também o interesse pelo Reiki (prática espiritual), que estudava com a pretensão futura de ensiná-lo, seu interesse por questões sociais, sua participação ativa nas decisões familiares, dentre outros. Num trecho do completamento de frases, exemplificamos, ainda, os vários interesses de Ananda.

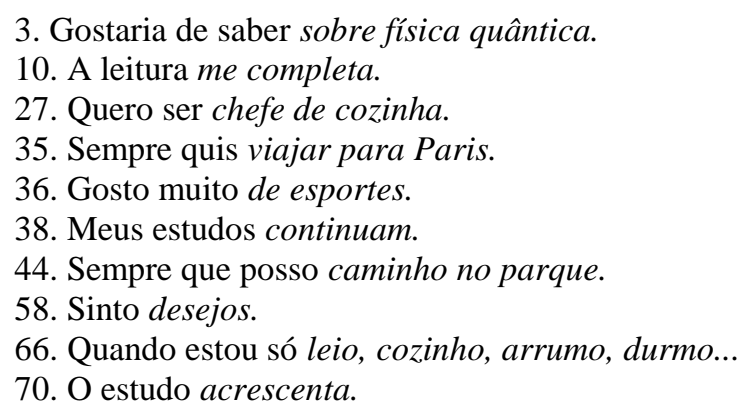

Para ela, a vida era composta de diferentes possibilidades de realização pessoal, de experiências, provavelmente, prazerosas e produtoras de sentidos subjetivos. Em nosso ponto de vista, essa variedade de interesses gerava em Ananda, em sua constituição subjetiva, um dinamismo capaz de favorecer movimentos, processos de formação de núcleos subjetivos e reconfiguração subjetiva que repercutia em um funcionamento criativo, o que será tratado mais adiante.

Esse funcionamento criativo diante da vida expressava-se também no trabalho pedagógico, que se tornava criativo e cenário favorável a uma produção subjetiva que repercutia em sua subjetividade individual. $O$ entendimento dessa dimensão funcional da criatividade pode ser evidenciado, ainda, nas aproximações à condição de sujeito e aos principais núcleos subjetivos da professora Ananda, o que trataremos a seguir.

\footnotetext{
${ }^{6}$ Projeto elaborado pelos profissionais da instituição com a finalidade de favorecer a superação de dificuldades de aprendizagem dos estudantes.
} 


\subsubsection{A subjetividade individual da professora Ananda: sua condição de sujeito e os núcleos} subjetivos que participavam de sua criatividade no trabalho pedagógico

Para Mitjáns Martínez (2008a), a condição de sujeito e as principais configurações subjetivas do professor participam de sua criatividade no trabalho pedagógico, aliadas às características do contexto onde atua e da subjetividade social do espaço escolar. Em consonância com o que afirma a autora, entendemos, no processo construtivo- interpretativo, que a manifestação da condição de sujeito em Ananda mostrou-se evidente em distintos momentos de sua vida, assim como no processo de pesquisa. Logo no início desse processo, ela quis sugerir o seu nome fictício e explicou, a partir do significado: ser feliz, o motivo de sua escolha.

O significado do nome escolhido relaciona-se, no nosso ponto de vista, à convicção da professora de que nasceu para ser feliz. Em sua primeira redação afirmou logo no início: “tenho certeza de que nasci para ser feliz!" (Ananda, Redação 1). Hipotetizamos que esse aspecto se constitui, certamente, em um princípio para ela, que norteia suas atitudes e ações, tanto no campo profissional como pessoal, implicando movimentos próprios e autênticos de superação das dificuldades que surgiam no curso de diferentes experiências.

$\mathrm{Na}$ situação da separação matrimonial, como citada anteriormente, Ananda relatou que gostaria de permanecer casada, "tentar mais", segundo suas palavras, mostrou-se triste ao falar a respeito do assunto. Em conversas informais e durante a terceira entrevista, falamos acerca dessa separação e ela reconheceu que o casamento não estava "bem" e que há tempos estavam tentando superar os conflitos. Ainda assim, ao discorrer sobre o tema, afirmou:

\footnotetext{
Qualquer ruptura eu acho difícil, mas ao mesmo tempo que é difícil você viver a ruptura, ela te abre muitas possibilidades, pelo menos pra mim. Eu nunca vi um fim de alguma coisa, uma separação de alguma coisa, sair de uma escola, procurar emprego, entregar currículo como fim, não! Pelo contrário, eu acho que a possibilidade, ela te motiva, né? A fazer alguma coisa nova, uma coisa diferente (Ananda, Entrevista III).
}

Ananda comentou que, antes desse momento, tentou várias alternativas para resgatar o relacionamento, e falou: "faço tudo que estiver ao meu alcance" (Ananda, Entrevista III), como conversas e passeios. Essas informações nos permitiram compreender o seu posicionamento diante da separação: ela havia tentado meios para superar os conflitos, mas como não tinham surtido os efeitos esperados, era preciso gerar novos "caminhos". Ela se posicionou de maneira ativa e não se vitimizou. Afirmou, ainda: “Acabou? Acabou! Não tem mais nada”. Depois, “eu não morro por ninguém não!”. (Ananda, Entrevista III). 
Essa situação e o protagonismo de Ananda na tentativa de superar o seu sofrimento nos permitiram entender o exercício da condição de sujeito, porque mesmo diante da emocionalidade que se constituía no momento, ela foi capaz de gerar espaços de subjetivação próprios, gerar alternativas para superar os conflitos vivenciados. Para González Rey (2011a, 2003), esses são aspectos que evidenciam essa condição de sujeito.

No trabalho pedagógico, Ananda possui forte intencionalidade pedagógica, colocava-se como autora de suas práticas educativas e protagonista de suas escolhas, aspectos que relacionamos a sua condição de sujeito em sua prática profissional. Era ela quem elaborava as atividades educativas, providenciava os materiais necessários e mudava o planejamento de acordo com as situações que se formavam no cotidiano educativo. Em um dia da oficina culinária, por exemplo, faltou um dos ingredientes para a realização da receita, solicitado, antes, pela professora. Ela, então, com os ingredientes disponíveis, fez outra receita.

Essa possibilidade de providenciar alternativas, protagonizando o seu trabalho pedagógico, bem como outras situações de sua vida, pode estar relacionada à flexibilidade como um recurso subjetivo. Diante de impasses, Ananda colocava-se como sujeito de suas escolhas e modificava a situação a fim de superar as dificuldades que se formavam. Além disso, havia a crença de que nasceu para ser feliz. Crença que interpretamos como uma produção subjetiva que se relacionava ao seu posicionamento ativo para a sua própria felicidade. Para ela: “A vida é essa, então vamos viver” (Ananda, Entrevista I).

Essa frase, aliada ao conjunto da construção das informações, possibilitou-nos compreender que Ananda se percebia agente de suas escolhas e se distanciava de qualquer possibilidade de sentir-se vítima dos acontecimentos. Ao contrário, ela buscava um posicionamento próprio e com responsabilidade e compromisso, enfrentava as situações que se formavam nos diferentes campos de sua vida. No completamento de frases registrou:

\footnotetext{
23. Amo a vida.

31. Considero que posso fazer o que eu quiser.

32. Esforço-me diariamente por atingir meus objetivos.

40. Farei o possível para alcançar minhas metas.

41. Frequentemente, reflito sobre ser cada vez melhor.

48. O passado passou.

49. Esforço-me com o agora.

54. Incomoda-me preguiça.

61. Quando tenho dúvidas procuro, descubro.

62. No futuro só o que eu desejo.

64. Meu maior prazer acordar, passar o dia bem.

73. Considero que posso muitas coisas.
} 
Entendemos que esse posicionamento ativo se constituiu a partir de núcleos subjetivos significativos em sua personalidade, como de sua autovaloração, que, mesmo caracterizandose como uma produção subjetiva relativamente estável, atualizava-se no curso do exercício da sua condição de sujeito. Dessa maneira, destacaremos, a seguir, aqueles núcleos subjetivos que, no processo construtivo-interpretativo, participavam da criatividade de Ananda em seu trabalho pedagógico e, consequentemente, perpassavam sua condição de sujeito.

4.1.5.1 Os principais núcleos subjetivos da professora Ananda que participavam de sua criatividade no trabalho pedagógico

No caso de Ananda entendemos que os núcleos subjetivos que integravam sua expressão criativa no trabalho pedagógico foram: a autovaloração, a profissão - ser professora, a relação com os alunos e a família. Esses processos subjetivos se constituíram a partir de sentidos subjetivos provenientes de diferentes experiências vividas pela professora, num processo histórico e atual.

\section{Autovaloração como um núcleo subjetivo}

No caso da professora Ananda, compreendemos que havia produções subjetivas relacionadas à autovaloração que participavam de sua criatividade no trabalho pedagógico. Construímos que, dentre os sentidos subjetivos que constituíam esse núcleo subjetivo, estavam aqueles relacionados à sua autoimagem, ao seu papel ativo diante da vida, à crença de sua capacidade de superação, segurança emocional e aceitação.

Os registros que a professora fez no completamento de frases, expostos a seguir, nos possibilitam exemplificar nossas construções acerca de sua autoimagem:

\footnotetext{
8. Sofro pouco.

13. Estou melhor agora.

20. Eu sou linda.

28. Creio que as minhas melhores atitudes são as espontâneas.

46. Frequentemente, sinto disposição, vontade, alegria.

51. Minha opinião é forte.

60. Quando eu era criança era tímida.
}

Nessas frases, interpretamos que Ananda se percebia como uma mulher forte, bonita, com disposição para a vida. De fato, no curso da pesquisa, ela se apresentava bem humorada e extrovertida, demonstrava vaidade e certo apreço por vestir-se bem. Ademais, atribuiu pouco sofrimento às suas experiências, acreditava na possibilidade de ter opinião própria, de que era 
capaz de superar-se, sendo hoje "o seu melhor". Compreendemos que esses aspectos estavam relacionados à sua autovaloração, a sentidos subjetivos associados a uma autoimagem como uma mulher forte.

Essa produção subjetiva relacionava-se ao posicionamento próprio de Ananda. No processo construtivo-interpretativo, consideramos que, para ela, as adversidades, os problemas que surgiam no decorrer da vida, precisavam ser superados e, para isso, ela precisava mobilizar-se, ter um papel ativo. A sua experiência profissional, por exemplo, iniciou-se logo após ter concluído o curso de magistério no ensino médio, atuando em uma escola municipal no interior de Minas Gerais, onde seu esposo havia ingressado no ensino superior. Naquele período, Ananda havia ficado grávida, aos dezessete anos de idade, e percebeu-se na necessidade de cuidar de sua filha, trabalhar e estudar. Ao relembrar esse momento, ela comentou:

Fiquei grávida com 17 anos. Ai, meu Deus! E agora? Vou chorar! Não! Vou ter um filho, pronto! [...] Eu nunca pensei na vida em abortar, tive três filhos. E pra mim, eu não tinha essa opção. Eu não via como: 'eu posso abortar', não. A minha opção era ter o filho, independente de qualquer coisa. Então, estou grávida. Vai nascer, vou cuidar. Vamos cuidar da vida! (Ananda, Entrevista I).

Interpretamos que, nessa situação, ela acreditou em si mesma, na capacidade de organizar-se e conciliar as diferentes demandas, sem abrir mão de sua formação e atuação profissional. Relatou: "Maria nasceu em junho. Eu adiantei tudo que podia, estágio... E terminei (curso Magistério) em dezembro" (Ananda, Entrevista I, inclusão da autora). Essa situação, e outras no decorrer da pesquisa, nos permitiram construir indicadores de que em Ananda se constituíram sentidos subjetivos relacionados a uma crença em si mesma, isto é, em sua possibilidade de superação e capacidade de lidar com as dificuldades que podiam surgir.

Tais produções subjetivas se vinculavam, também, ao trabalho pedagógico, aos processos subjetivos que se constituíam a partir de sua atuação profissional. Ananda, no curso das observações, mostrou-se segura na condução de suas atividades profissionais, diante dos alunos e demais integrantes da dinâmica educativa. Tanto que organizava o seu trabalho pedagógico conforme suas escolhas e crenças, flexibilizando o seu planejamento segundo situações que surgiam.

Esses posicionamentos, no nosso ponto de vista, estavam articulados ainda a sentidos subjetivos associados à segurança emocional que Ananda possuía diante dos alunos. Esses processos subjetivos se relacionavam às experiências profissionais da professora ao 
longo de mais de vinte anos de magistério e das relações que se formaram no grupo de profissionais e demais professores presentes naquela instituição educativa.

No período de observação, presenciamos muitos elogios entre os professores acerca de atividades educativas realizadas, dos painéis construídos, relatos de experiências em sala de aula, demonstração de apoio entre eles a respeito das escolhas pedagógicas. No momento de apresentação da pesquisa para a direção, por exemplo, a diretora mostrou, com nítido orgulho, a agenda produzida a partir de tarefas, fotos de alguns momentos, eventos e desenhos produzidos pelos alunos. Essas situações nos possibilitaram construir indicadores acerca de uma emocionalidade positiva existente entre os profissionais, produções subjetivas que repercutiam para o reconhecimento de que o trabalho pedagógico desenvolvido por eles, naquela instituição, era valorizado.

Nesse espaço escolar, a autovaloração de Ananda abrangia, assim, sentidos subjetivos vinculados à aceitação, que se constituíam nas próprias relações sociais que se formavam naquele contexto, a partir de elogios sobre suas produções pedagógicas, dos murais que produzia, do valor que os demais profissionais atribuíam às suas ideias e colocações, como presenciamos em alguns diálogos entre eles. Entendemos que situações como essas, podem ter colaborado para produções subjetivas, que lhe favoreciam sentir-se acolhida e aceita por aquele grupo, o que, certamente, participava de sua autovaloração.

Ananda, apesar de manter um bom relacionamento com os profissionais da instituição, indicou em conversa informal que apreciava o fato de ser a única professora do $5^{\circ}$ ano do turno em que atuava. Justificou que essa situação lhe conferia autonomia em sua ação pedagógica, liberdade de escolha e decisão na organização do trabalho pedagógico. Interpretamos que essa situação, de "única professora", também favorecia a legitimidade de suas práticas educativas, de seus argumentos para as estratégias de ensino que propunha para sua turma e, consequentemente, para sua expressão criativa no trabalho pedagógico. Tal posicionamento nos permitiu interpretar que havia em Ananda sentidos subjetivos relacionados ao individualismo, os quais se vinculavam a sua autovaloração.

Consideramos que o núcleo subjetivo relacionado à autovaloração participava, também, da produção subjetiva que configurava sua profissão - ser professora. A forma como ela se percebia e se reconhecia, perpassavam suas escolhas profissionais e constituíam a organização do seu trabalho pedagógico criativo. Atrelado à forma como Ananda se percebia, estava o valor social que conferia à profissão de professora, a qual, no curso do processo construtivo- 
interpretativo, foi considerada como um núcleo subjetivo relevante em sua subjetividade individual.

\section{A profissão como um núcleo subjetivo}

No curso da pesquisa, compreendemos que havia uma identificação de Ananda com a profissão, uma importância social que conferia ao "ser professora", aspecto que se articulava às suas ações intencionais no trabalho pedagógico, ao seu esforço em oferecer um processo de ensino favorecedor da aprendizagem dos alunos. Para ela: "cada dia que passa, tenho mais claro dentro de mim que nasci mesmo pra ser professora" (Ananda, Redação I). A profíssão era algo que não questionava, fazia parte dela, da sua identidade. Relacionado a essa identificação, afirmou: "somos (professores) muito importantes no processo de formação das crianças, futuros adultos.”. (Ananda, Redação I, inclusão da autora).

Esse processo de identificação de Ananda advém, provavelmente, de um processo histórico, do qual participaram o orgulho de seu pai ter sido professor universitário e as produções subjetivas decorrentes de suas próprias experiências pessoais. Para ela, fazer o curso de magistério no ensino médio foi uma escolha: "Fiz Escola Normal, pois desde muito pequena queria ser professora, acho que nasci para isso mesmo" (Ananda, Redação I). E foi essa formação que lhe possibilitou, logo ao final de sua conclusão, o ingresso no mercado de trabalho e sua independência financeira.

Consideramos que essa escolha pelo magistério esteve relacionada, ainda, à importância social que Ananda conferia, e até hoje confere, à profissão, de tal modo que afirmou: "vejo a educação como o início, o meio e o fim para todas as coisas” (Ananda, Redação I). Essa importância implicava, por sua vez, uma produção subjetiva relacionada à responsabilidade e ao compromisso profissional de Ananda, o que se revelava diante de si mesma e dos estudantes. Esses sentidos subjetivos movimentavam o seu empenho em fazer um trabalho pedagógico "diferente"; bem como, o seu interesse pelo processo de planejamento e realização das práticas educativas elaboradas por ela. A respeito desse processo, registrou:

Gosto de pensar, repensar e planejar o que vou fazer na prática. O resultado disso passa por um crivo grande, pois não me contento com pouca coisa, procuro fazer sempre bem feito, com excelência e qualidade. Sou exigente! (Ananda, Redação II).

Compreendemos que essa exigência de Ananda em seu trabalho pedagógico fazia com que ela se mobilizasse para a produção de novidades com valor para os processos de 
aprendizagem e desenvolvimento dos estudantes, para a produção de atividades educativas que os envolvesse e oportunizasse experiências relevantes no espaço escolar. Esse processo de elaboração, realização das práticas educativas produzidas por ela e participação ativa dos alunos, favorecia uma produção de sentidos subjetivos que se relacionam à satisfação, ao prazer em atuar como professora. Para ela: "a dedicação, o empenho, o envolvimento, tudo o que eu faço, realmente, me satisfaz" (Ananda, Redação II). Ao completar frases, a professora expressou:
6. Na escola aprendo.
18. Minha profissão um dom.
29. Esse ano letivo está sendo ótimo.
68. Se trabalho acredito, me dedico.

Ananda acreditava em seu trabalho como professora, dedicava-se a ele com compromisso e seriedade. Ela reconhecia que esses aspectos existiam em outros profissionais que atuavam naquela instituição, os quais trabalhavam em "união". Ao falar acerca da instituição, ela afirmou:

\begin{abstract}
Aqui na escola eu vejo o grupo bem unido, bem unido! Eu vejo o grupo muito preocupado sim com a qualidade do trabalho. Eu vejo o grupo bem interessado sim em fazer um serviço bom, em ensinar de fato, não só os conteúdos, mas valores, a educação fora do currículo, não formalizado, para as crianças. Eu vejo bem assim mesmo. É o que me prende aqui. As pessoas, eu nunca fui pressa às pessoas, nunca. A qualidade do trabalho sim me prendia, me mantinha numa escola ou na outra. Não me vejo trabalhando dentro de uma hipocrisia, dentro de uma coisa mais ou menos. Eu não sou mais ou menos, eu sou muito, eu sou tudo, porque eu vou ser mais ou menos? Não dou conta disso, não dou conta. (Ananda, Túnel do tempo).
\end{abstract}

No curso da pesquisa, interpretamos que a professora reconhecia a união entre os profissionais da instituição, o direcionamento existente para que fosse realizado um "trabalho de qualidade", o que para Ananda estava além das disciplinas, das diretrizes curriculares que precisavam considerar. Foi esse trabalho diferenciado que a fez permanecer na instituição por cinco anos ${ }^{7}$ e que, de certa forma, colaborou para sua criatividade no trabalho pedagógico. A propósito dessas relações para a expressão criativa, Mitjáns Martínez (2004, p. 91) afirma:

A subjetividade social da escola em geral e dos grupos dos quais o sujeito participa, essencialmente a sala de aula, têm nesse processo de constituição um importante papel, pelas reflexões e vivências emocionais que produzem no sujeito e pelo significado e valor que atribuem às ações pessoais, influenciando o sujeito de formas diversas.

Compreendemos que essa forma de Ananda subjetivar as relações e o trabalho pedagógico da instituição educativa pode ter contribuído para o movimento intencional da professora voltado à produção de novidades com valor para os processos de aprendizagem e

\footnotetext{
${ }^{7}$ No final do ano letivo de 2013, Ananda solicitou remanejamento interno. Explicou que em decorrência de sua separação, precisou se reorganizar quanto à proximidade do local de trabalho e diminuição de despesas.
} 
desenvolvimento dos estudantes, implicando-a para o protagonismo em sua prática profissional. Tais indicadores foram construídos por um conjunto de informações que se expressaram na pesquisa e pode ser exemplificada pela fala acima, em que Ananda afirmou: "A qualidade do trabalho sim me prendia, me mantinha numa escola ou na outra. [...]. Eu não sou mais ou menos, eu sou muito, eu sou tudo, porque eu vou ser mais ou menos?" (Ananda, Túnel do tempo).

Nessas frases da professora, interpretamos, ainda, um processo subjetivo de identificação com o trabalho pedagógico realizado naquela instituição educativa. Isso, aliado às pessoas com as quais Ananda se relacionava, as relações históricas construídas entre eles, os valores e crenças que se formaram predominantes naquele contexto participavam da produção subjetiva que implicava a criatividade da professora em seu trabalho pedagógico.

Nesse processo, o outro foi um incentivador, estimulador do desenvolvimento de recursos subjetivos associados à criatividade, como afirma Mitjáns Martínez (2004). Para a autora, a dimensão relacional do social é fundamental para subjetividade individual, pois é "[...] por meio das relações com os outros que se vai constituindo a subjetividade individual (tanto na sua expressão em termos de sujeito quanto de personalidade), e, como parte dela, constituem-se também as configurações criativas.” (MITJANS MARTINEZ, 2004, p. 87)

A crença de Ananda nos outros profissionais da instituição, em seu próprio trabalho e sua dedicação à profissão repercutiam em seu trabalho pedagógico, o qual era permeado pelos objetivos de aprendizagem escolhidos pela professora e por seu desejo em colaborar para a aprendizagem e desenvolvimento dos estudantes. Ao ser questionada sobre os recursos pedagógicos que utilizava em sua prática profissional, Ananda afirmou:

[...] é para diversificar a forma de aprender mesmo. Eu acredito que a gente aprende com mais facilidade quando a gente vive aquilo. Como você vai viver aquele período de colonização, de escravidão no Brasil? A gente não vive mais isso, é história, passado, é só livro, só livro. Então, tá! Vamos comer a rapadura, vamos experimentar o gosto da época? Vamos fazer um teatro, como a gente está fazendo um teatrinho sobre a vida do escravo, a imposição do branco em cima do negro, o sofrimento, sobre a dor no negro. Então, assim, eu acho que dessa forma indireta, você está trabalhando o conteúdo e está dando significado diferente pra aquilo, ele tá vivendo de algum forma uma coisa muito remota. A gente não tem dimensão, não consegue mensurar isso. (Ananda, Entrevista II).

Tais informações a respeito dos recursos pedagógicos, aliadas a outros momentos da pesquisa, nos permitiram construir, ainda, a forma como Ananda subjetivava a aprendizagem: como uma construção que estava além da reprodução de conteúdos envolvia a compreensão do tema. Interpretamos que, por isso, ela enfatizava a possibilidade dos estudantes "experimentarem" o tema, seja com um alimento ou com uma dramatização. E 
que o entendimento da aprendizagem, como construção e compreensão a respeito dos temas, participava da criatividade de Ananda em seu trabalho pedagógico, favorecendo a elaboração, proposição de atividades educativas que possibilitasse aos alunos essa compreensão. Ao discorrer acerca das experiências profissionais que gostaria de transformar, ela relatou:

\footnotetext{
Eu gosto do que eu faço. Eu sempre procurei fazer tudo com muito capricho, muito gosto, muita seriedade, com respeito aos meus alunos. Então, eu sinceramente não me lembro de coisas assim que eu quisesse mudar. Eu sempre fui muito cuidadosa. Eu sempre procurei fazer o melhor possível... Eu sempre quis acertar mais, do que está errando. (Ananda, Túnel do tempo).
}

Entendemos essa seriedade de Ananda como uma produção subjetiva relacionada ao seu compromisso profissional, relacionada aos desejos por superação, produção de atividades educativas que fossem "diferentes" e oportunizassem a compreensão dos assuntos em pauta. Aspectos esses que associamos a sua orientação muito ativa para a superação no campo profissional, como também foi identificado por Mitjáns Martínez (2003a) em pesquisa anterior com profissionais criativos. Nessa busca por superação, participavam processos reflexivos sobre o seu trabalho pedagógico, de modo que, ao ser questionada se pensava acerca de seu trabalho docente, ela respondeu "eu penso, penso muito... até canso de pensar. Mas eu gosto, isso me ajuda a argumentar, a criar" (Ananda, conversa informal).

Esse posicionamento reflexivo da professora se relaciona à condição de sujeito em sua prática profissional, tanto pelo seu pensamento intencional, consciente, como pelos indícios de que nesse processo há produção de sentidos subjetivos vinculados ao seu trabalho pedagógico. A propósito, ressaltamos o que nos afirma González Rey (2007b, p. 159) a respeito do pensamento e da produção de sentidos subjetivos:

\footnotetext{
Não existe pensamento sem emoção, o sujeito somente pensa em questões que são significativas para ele; portanto, o pensamento apenas aparece em temas com sentido subjetivo, daí sua significação na definição de sujeito.
}

Compreendemos que esses processos de pensamento sobre o seu trabalho pedagógico implicavam uma produção subjetiva que se organizava como motivos para sua atuação profissional. Esses motivos não são estáticos ou cristalizados por detrás do comportamento da professora, ao contrário, o próprio pensamento se constitui como um processo motivador, como momento da configuração subjetiva que se organiza no curso da ação docente, como nos aponta González Rey (2012).

No caso de Ananda, consideramos que havia um alto nível de motivação para a profissão, como foi identificado também por Mitjáns Martínez (2003a) em profissionais criativos. E mais, para a professora, o trabalho pedagógico constituía-se como um núcleo subjetivo relevante em sua subjetividade individual, caracterizava-se como uma tendência 
orientadora de sua personalidade, pois a partir de seus recursos subjetivos, como imaginação e flexibilidade, e dos processos que constituíam seus principais núcleos subjetivos, ela se mobilizava, intencionalmente, para a produção de novidades com valor para os processos de aprendizagem e desenvolvimento dos alunos.

Havia, assim, por parte de Ananda, a característica apontada por Mitjáns Martínez (2003a, p. 62) como essencial para a compreensão das tendências orientadoras da personalidade: “[...] a elaboração consciente dos projetos por parte do sujeito e seu esforço na consecução de seus fins e propósitos, ou seja, o envolvimento efetivo do sujeito em uma esfera de atividade que lhe resulte altamente significativa."

Existia em Ananda um desejo consciente de produzir atividades educativas que fossem “diferentes" e que resultassem na aprendizagem e na satisfação dos alunos em realizá-las, a ponto de ser marcante para a vida deles. Tanto que a profissão ocupava um tempo significante de suas atividades, lembrando-se dos estudantes e do seu trabalho pedagógico mesmo em situações de passeio, como relatado em entrevista. Essa orientação consciente para a criação identificada em Ananda também foi encontrada por Mitjáns Martínez (2003a) em profissionais criativos.

No núcleo subjetivo que se constituía em sua profissão participavam, assim, sentidos subjetivos relacionados à superação profissional, ao prazer de dar aulas, aos processos reflexivos que envolvem o planejamento, bem como sentidos subjetivos que se constituíam nas relações com seus alunos. No entanto, reconhecemos, no curso da pesquisa, que participavam também outras produções subjetivas, as quais davam formas ao desânimo de Ananda com a sua profissão.

Ao ser questionada a respeito do retorno financeiro, ela afirmou que os professores deveriam ter um salário melhor, em função da exigência que há em relação ao seu trabalho e os resultados esperados. E que pensar sobre o seu salário, a fazia pensar em deixar de ser professora. Para ela: "Essa questão do salário pesa" (Ananda, Entrevista III).

$\mathrm{Na}$ redação produzida acerca dos sentidos da sua vida, relatou também:

Nasci para isso mesmo [...]. Gosto de ser professora, acho que não saberia fazer outra coisa [...]. Mas, as vezes tenho a impressão que nós professores sempre morremos na praia das lutas [...] isso em alguns momentos desanima e dá vontade de mudar de profissão, as vezes, digo: 'já sei ser professora, posso mudar de profissão'. Mas não consigo. (Ananda, Redação I).

Nesse trecho, Ananda discorreu a respeito de sua vontade de mudar de profissão. Em entrevistas e conversas informais acerca dos fatores que poderiam conduzir a tal mudança, ela apontou o cansaço que sentia ao voltar-se para os fatores que "dificultam" a aprendizagem 
dos estudantes, aos mais de vinte anos de profissão e, também, às mudanças constantes que acontecem nas diretrizes pedagógicas e curriculares na Secretaria de Educação. Compreendemos, assim, que o seu "desânimo" pode ser relacionado ao seu compromisso profissional, ao seu desejo de fazer o "melhor" para os estudantes, o que acabava por ser minado, dentre outros fatores, em função daquelas mudanças.

Ananda reconhecia que, mesmo quando pensava nessa mudança, direcionava-se para a docência: "quando penso em mudar de profissão (às vezes penso) sempre aparece no final a docência. Chega ser estranho e engraçado tentar mudar e lá estou eu professora de novo" (Ananda, Redação II). Essa afirmativa atrela-se aos seus planos futuros, ser professora de Reiki. Para ela: "gosto de ser professora, acho que não saberia fazer outra coisa, além de cozinhar que também é uma paixão.” (Ananda, Redação I). Esse retorno à docência, ao ser professora, pode ser interpretado a partir da satisfação que sentia em ensinar e dar aulas, o que certamente, gerava em Ananda sentidos subjetivos favoráveis ao seu bem estar emocional, favorecendo com que, apesar de julgar ser merecedora de um salário "melhor", se mantivesse na profissão.

Desse bem estar, participavam, ainda, as relações entre a professora e os alunos. Essas relações que Ananda construía no contexto escolar, se tornavam palco para uma produção subjetiva capaz de se organizar em núcleo subjetivo em sua personalidade, qual seja: a relação com os alunos como um núcleo subjetivo importante em sua subjetividade individual.

\section{A relação com os alunos como um núcleo subjetivo}

Ao apresentarmos as expressões da criatividade em Ananda, construímos indicadores que ressaltavam a sua criatividade nas relações com os alunos. Neste momento, enfatizaremos o papel das relações com aqueles estudantes para a expressão criativa da professora no seu trabalho pedagógico. Isso porque entendemos que a forma personalizada com que ela se relacionava com os alunos se constituía a partir de uma produção subjetiva que se organizava como um núcleo subjetivo, que integrava e ao mesmo tempo se formava no bojo das relações, repercutindo no seu desejo de produzir atividades educativas que fossem "diferentes".

Essa busca, no entanto, não se sustentava fora das relações sociais que Ananda construiu no espaço escolar, em especial, com seus estudantes. No intuito de favorecer a aprendizagem de cada um deles, a partir da relação que se formava entre professora e alunos, ela se voltava para a produção de novidades com valor para a aprendizagem e 
desenvolvimento de cada um. Nesse processo, participavam sentidos subjetivos associados à responsabilidade com sua atuação profissional, em que ela se via como responsável por elaborar um trabalho pedagógico que viabilizasse aprendizagens e, mais, que fossem prazerosas aos seus estudantes. Para ela:

\begin{abstract}
Eu acho assim... Vamos dizer, eu sou o adulto da relação, eu sou ser pensante para estruturar pedagogicamente. Mas eles têm o direito dessa participação, porque são eles que estão aprendendo, né? Eles têm estar afim, que manifestar, que trocar, que dá ideias [...] Dentro do que eu vou ouvindo, eu vou mudando, adaptando, faço do meu jeito e depois a gente faz assim. Pra não perder a estratégia pedagógica, o fim da atividade que eu planejei, depois a gente faz assim. (Ananda, Duas grandes premiações).
\end{abstract}

Essas produções subjetivas relacionadas à sua responsabilização no processo de ensino se articulavam à maneira como Ananda subjetivava o seu papel na relação professoraluno, a forma como ela subjetivava o professor: a ela, como professora, cabia pensar e estruturar o trabalho pedagógico. A professora chamava para si a responsabilidade para com a organização do trabalho pedagógico, o que repercutia para a formulação de "[...] metas e objetivos sobre o que e para quem deve realizar" (TACCA, 2004, p. 108), do que decorria o como realizar suas ações educativas. Para Tacca $(2004$, p. 108) “[...] integrar esses aspectos inclui observar diversas dinâmicas do processo ensino-aprendizagem”. Dentre elas, a autora cita: o aluno concreto, a dinâmica dos relacionamentos, do conhecimento e das estratégias de ensino.

Há, ainda, naquele trecho, expressões relacionadas ao respeito aos alunos e ao papel que eles possuíam nessa relação pedagógica, o que, compreendemos, vincula-se à forma como ela subjetivava o estudante: ele tinha um lugar na dinâmica educativa, um papel ativo em sua aprendizagem. E, de fato, no curso das observações, foi possível notar a participação ativa dos alunos, seja por meio das falas, dos diálogos, como na elaboração de um planejamento pedagógico que lhes fosse atraente e interessante. Compreendemos que essa participação dos estudantes se dava dentro do sistema relacional formado entre eles e a professora, em que se constituía um clima comunicativo-emocional permeado pelo respeito mútuo e valorização do papel desempenhado por cada um dos integrantes. Nesse sistema, emergiam sentidos subjetivos relacionados ao respeito aos alunos, a essa participação no processo de aprendizagem, o que favorecia a consideração de seus interesses, a valorização de suas ideias no curso das atividades educativas desenvolvidas.

De modo geral, entendemos que existia um direcionamento respeitoso em relação aos alunos na organização do trabalho pedagógico da instituição educativa, o que permitia essa participação por parte deles nas atividades realizadas. Havia momentos em sala de aula, mas 
também em espaços como quadra de esportes, lanche coletivo no pátio interno, trabalhos específicos no espaço da sala de leitura, dentre outros. Espaços organizados para o estudo, em locais diferenciados, e outros, para a brincadeira, diversão. Esse aspecto nos permitiu hipotetizar um respeito à infância e à possibilidade de que, nessa diversidade de momentos, os alunos experimentassem diferentes interações sociais entre eles, espaços de troca, negociação, resolução de conflitos e disputas.

Consideramos que essa forma de organização do trabalho pedagógico favorecia a atualização em Ananda, de sentidos subjetivos relacionados à compreensão de que os alunos também são crianças. Para ela, as crianças tinham um papel relevante não apenas em seu trabalho pedagógico, mas em sua vida de forma geral. Em diversos momentos da observação, a professora nos relatou experiências vividas na infância com seus filhos e, no momento, com seus netos. Também, chamou a atenção para as expressões e reações de seus alunos em sala de aula, indicando valorização de suas colocações e conferindo prazer e satisfação em conviver com eles, dizia sorrindo: “Como eu me divirto com eles!”.

Dessa forma específica de como a professora subjetivava a criança, participou, certamente, a experiência que Ananda nos relatou que gostaria de reviver em sua trajetória profissional. Nessa situação, um aluno de quatro anos estava batendo muito nos colegas, que reclamavam dele. A professora o retirou da atividade e solicitou que ele pensasse em suas atitudes. Depois de alguns minutos, ele lhe respondeu: "Se você não for uma professora boazinha, você não ganha balinhas". Nesse momento, disse que teve vontade de apertar ele, beijar, abraçar. E que foi uma experiência marcante porque não esperava essa reação dele, tinha quatro anos e demonstrou esse nível de entendimento, esclarecimento do que o deixou chateado, e estava querendo chantageá-la. Foi uma situação que a fez olhar para o aluno de uma forma diferente e pensar na importância da criança.

O ser criança... Isso sempre me chamou muita atenção. Tanto é que eu trabalho com
criança, porque gosto. O cuidado que a gente tem que ter com a criança, respeitar,
valorizar, reconhecer que aquele ser humano ali é um ser em formação e ao mesmo
tempo, na minha crença espiritual, já vem com uma bagagem muito grande. É um
ser que, se a gente for pensar, ele é o que a gente é hoje [...] A criança é ao mesmo
tempo pura, linda, livre, solta, pesada, densa, cruel, como a gente. A gente cresce e
continua sendo isso tudo: cruel, lindo, livre, solta, pesado, denso, alegre, triste.
Então mudou só o tamanho, mudou, assim, de repente, só a forma. (Ananda, Túnel
do tempo).

Esse trecho, aliado a outras informações da pesquisa, nos possibilitou construir a forma como Ananda subjetivava as crianças: como seres dotados de sentimentos, de liberdade, de encantamentos, de potencial para a construção de conhecimentos. Compreendemos que essa forma de entender as crianças participava da expressão criativa de Ananda em seu 
trabalho pedagógico, fazendo-a produzir atividades em que os alunos fossem ativos e participativos, implicando-a em movimentos próprios e de superação em sua prática profissional.

No sistema relacional que existia entre professora e alunos, formavam-se vínculos afetivos: "é como se fossem meus. Choro todo fim de ano, não quero deixá-los ir embora" (Ananda, Túnel do tempo). Para Ananda, os alunos eram "seus", trecho que, em conjunto com outras informações, nos permitiu entender o que González Rey (1995) afirma acerca das relações humanas: toda relação humana implica uma configuração subjetiva que pode se expressar na representação do sujeito a respeito da relação.

Esse vínculo participava de sua atuação profissional, relacionava-se à sua implicação profissional, ao cansaço que citou ao discorrer sobre sua profissão. Para ela: "Ver que a criança não atingiu os objetivos esperados, por um ou outro motivo, me cansa pensar assim: o que eu posso fazer pra esse menino chegar lá, me cansa pensar os fatores, os fatores dele, não os meus, dele, que não deixam ele alcançar os objetivos" (Ananda, Túnel do tempo). Essa situação nos possibilitou entender a presença desse vínculo entre a professora e os seus alunos, e como ele implicava sua criatividade no trabalho pedagógico. A professora comentou também:

Eu quero que todos aprendam do jeito que eu acho que eles têm que aprender, eu quero que todos saiam de zero a cem, duzentos. E quando eu vejo que o retorno não é assim, e não é assim, eu sei disso, isso me cansa. (Ananda, Túnel do tempo).

Interpretamos, a partir desses trechos, que havia em Ananda sentidos subjetivos vinculados ao seu compromisso profissional, um forte intuito de favorecer a aprendizagem dos alunos e, com isso, a sua mobilização para compreender esse processo e o seu esforço para que o trabalho pedagógico oportunizasse aprendizagens. Consideramos que essa produção subjetiva acerca do seu compromisso profissional se constitui com base no sistema relacional entre professora e alunos, na relação personalizada com cada um deles e por serem eles "queridos e especiais" (Ananda, Redação I), como ela registrou.

No caso de Ananda, essa relação com seus alunos se constituía por meio de processos de comunicação que implicavam um clima comunicativo-emocional que favorecia o desenvolvimento de processos subjetivos vinculados à criatividade da professora no trabalho pedagógico e em produções subjetivas que se configuravam a partir das relações com seus estudantes. Esses eram processos e produções subjetivas que favoreciam movimentos em seus principais núcleos subjetivos, como aqueles relacionados ao exercício da sua condição de sujeito e ao seu protagonismo em seu trabalho pedagógico. 
Nessa perspectiva, consideramos que Ananda se implicava e se envolvia nas relações com cada um dos seus alunos e, para favorecer aqueles processos, ampliava o seu repertório de ações, de estratégias pedagógicas, de métodos de ensino, voltando-se intencionalmente para sua superação profissional. Nisso, percebemos sua possibilidade de autoria no trabalho pedagógico, de geração de alternativas próprias e autônomas, que favoreciam sua condição de sujeito e (re) configurações subjetivas, tanto no campo profissional como no pessoal e, ao mesmo tempo, era possível por meio de sua expressão como sujeito.

No curso desse sistema relacional se formavam motivos para sua criatividade no trabalho pedagógico, para Ananda era preciso favorecer a aprendizagem dos seus alunos e era preciso, ainda, que, se isso lhes fosse agradável, deixasse "lembranças". Interpretamos, assim, que se fazia necessário o seu papel ativo e criativo no trabalho pedagógico, a elaboração de atividades e estratégias educativas que atendessem aos seus alunos. Esse movimento intencional e comprometido da professora estava relacionado aos sentidos subjetivos que se constituíam no contexto escolar, nas relações com os estudantes, e se relacionavam, ainda, a outros espaços sociais de interação, como a família.

A propósito, destacamos um entrelaçamento das áreas profissional e pessoal na vida da professora Ananda, que se mostrou significativo no curso da construção das informações. Para ela os espaços-tempos entre sua profissão e sua família estavam extremamente próximos. Ao discorrer sobre sua trajetória profissional, por exemplo, a professora registrou: "A profissão sempre esteve carregada pelos filhos que iam e vinham das escolas particulares comigo" (Ananda, Redação1). Esse trecho, em conjunto com outros momentos da pesquisa, nos permitiu compreender que em Ananda as relações com sua família viabilizavam a formação de um núcleo subjetivo importante em sua subjetividade individual, que também se vinculava ao seu trabalho pedagógico criativo.

\section{A família como um núcleo subjetivo}

No caso de Ananda, consideramos que em sua história de vida, as relações com os seus irmãos e pais oportunizaram uma amplitude de experiências que geraram na professora produções simbólicas e emocionais que se configuraram subjetivamente, que integravam sua forma de atuar e que participavam de sua criatividade no trabalho pedagógico.

Em entrevista, ao falar a respeito de sua infância, destacou as mudanças de cidades vividas durante esse período: 
Tinha ano que eu estudava em três escolas, então foi uma infância sem apego nenhum, nem a amizades, a lugares, nem casas, nem nada, foi uma infância cigana. Até que em... 83, 84 a gente voltou para Brasília, para essa quadra e aí meu pai separou da minha mãe. Então, a gente ficou e ele foi embora, continuou mudando, mudando por conta do trabalho. E a gente ficou aqui, aí que as coisas começaram a se fixar mais, aí que a gente começou a ter uma história. (Ananda, Entrevista I).

Interpretamos que essa situação, possivelmente, favoreceu com que Ananda se voltasse para novas adaptações, seja na organização do lar, seja na construção de novos vínculos com as pessoas da vizinhança, das escolas. Esse processo de adaptações pode ter favorecido o desenvolvimento de recursos subjetivos como sua flexibilidade em adaptar-se a diferentes contextos, sua autonomia em lidar com seus conflitos, uma autoconfiança em si mesma, os quais implicavam e participavam da condição de sujeito em Ananda e em seu protagonismo e autoria no trabalho pedagógico.

Esse panorama de mudanças pode ter favorecido, também, os vínculos entre os irmãos e destes com a figura materna. Em conversa informal Ananda nos contou, com nítido orgulho, que eles são muito unidos e, frente a dificuldades, recorrem a ela para apoio, conselhos e maior segurança diante de situações vividas, como a separação de um de seus irmãos e o dia em que um deles foi preso em uma delegacia de polícia. Momentos que podem favorecer a constituição de sentidos subjetivos associados ao reconhecimento social e a sua autovaloração.

Em seu núcleo familiar, percebemos que seus pais possuíam participações distintas: o pai era mais distante fisicamente por conta da sua atuação profissional e depois devido à separação matrimonial, mas, ainda assim, presente em decisões como seu casamento aos dezessete anos de idade (como ela relatou em entrevista). A mãe foi mais presente em termos de exemplo de conduta e apoio às dificuldades enfrentadas, como a gravidez ainda na adolescência e sua primeira separação matrimonial com o segundo filho ainda bebê.

Essas relações de Ananda com o seu pai e sua mãe e, as mudanças para diferentes espaços sociais e culturais que viveu podem ter colaborado para a constituição de sentidos subjetivos associados ao seu enfrentamento e posicionamento ativo, o que participava também de sua criatividade no trabalho pedagógico. Isso porque, em cada novo espaço, Ananda voltava-se para a adaptação em um novo ambiente.

Ao escrever sobre o sentido da sua vida, Ananda registrou a respeito da separação de seus pais: "Depois da última mudança, nos fixamos aqui [...] e meu pai seguiu o caminho dele. Daí a vida mudou muito, longe do pai e perto da sobrevivência, nos vimos com a missão de ser. Ser gente e feliz!" (Ananda, Redação I). Interpretamos, nesse momento, o seu enfrentamento, a geração de alternativas próprias e autônomas, a criatividade em sua 
dimensão funcional. Mesmo diante de uma situação que lhe causou mudanças e sofrimento, Ananda enfrentou e tomou "decisões" que favoreceram movimentos, mudanças subjetivas: “ser gente e feliz!".

Assim, apesar do apoio que os seus pais conferiam às suas decisões, hipotetizamos que as experiências vivenciadas nesse núcleo familiar podem ter favorecido a formação de sentidos subjetivos relacionados à autonomia, bem como à responsabilidade $\mathbf{e}$ posicionamento ativo diante das diferentes situações. Indicadores a esse respeito podem ser observados na situação em que Ananda ficou grávida aos dezessete anos, no último ano do ensino médio. Nessa situação, seus pais lhe ofereceram apoio, mas não assumiram os cuidados com o bebê, e logo Ananda se casou e começou a trabalhar como professora. Nesse processo podem ter participado sentidos subjetivos vinculados ao acolhimento, segurança emocional e sua responsabilidade diante do novo momento.

Consideramos que essa forma de relacionamento de Ananda com seus pais repercutiu em sua criatividade no trabalho pedagógico, implicando seu protagonismo, no processo de elaboração de práticas pedagógicas que fossem novas e com valor para a aprendizagem de seus estudantes. Repercutiu, também, na relação que possuía com seus três filhos, os quais, no momento da pesquisa, junto aos dois netos, formavam um núcleo familiar de grande possibilidade de produção subjetiva. Esses sistemas relacionais em sua família integravam sentidos subjetivos diversos, como aqueles relacionados ao seu papel de mãe e de avó e ao apoio familiar, que se configuraram subjetivamente de forma histórica e que balizam os sistemas relacionais atuais.

Situações como o posicionamento de Ananda na escolha da profissão de sua filha mais velha, que mudou de curso por duas vezes e parou os estudos na graduação em decorrência das demandas de ser mãe na adolescência e precisar trabalhar, apontam que, apesar do apoio, Ananda instigava a autonomia de seus filhos e sua responsabilidade diante da vida. Nessa situação, e com base em outras informações da pesquisa, construímos indicadores acerca dos sentidos subjetivos que envolviam o seu papel como mãe e que abrangiam sua responsabilidade para com os filhos e a importância de lhes oferecer apoio sem, no entanto, tomar para si suas demandas.

Em entrevista, ela afirmou que os filhos sempre foram tudo, mas que a limitaram de tudo. Por eles, precisou abrir mão de muita coisa, precisava cuidar deles, estudar, trabalhar. Atualmente, têm dois netos, o que não acha ruim. Sua mãe a ajudou e ela quer ajudar os seus filhos também. Ao completar frases, expressou:

2. O tempo mais feliz com a família e de férias. 
5. Meu maior medo perder um filho.

43. Meu maior tempo dedico a família.

53. O lar minha tranquilidade.

57. Uma mãe a minha.

59. Os filhos são minha vida, alegria, e, do mundo.

67. Meu maior temor perder um filho.

74. A felicidade hoje, agora, Isadora, Daniel.

Interpretamos que, para Ananda, a família era um núcleo subjetivo relevante em sua organização subjetiva. A emocionalidade expressa por ela e a intensa presença de assuntos familiares em diálogos com a pesquisadora e com outros integrantes da dinâmica educativa nos permitiram entender a importância de tais relações para a professora.

Com base na compreensão desses principais núcleos subjetivos de Ananda, aprofundaremos a seguir os processos de movimento em sua subjetividade individual relacionadas à expressão criativa da professora em seu trabalho pedagógico.

\title{
4.1.5.2 Os processos de movimento na subjetividade individual da professora Ananda
}

O estudo da subjetividade individual evidencia os movimentos contínuos decorrentes das produções subjetivas, que se constituem a partir das atividades, relações e ações humanas. Como observado anteriormente, na fundamentação teórica desta pesquisa, os impactos, as mudanças, o movimento, enfim, a mobilidade dos processos simbólicos e emocionais marcam o desenvolvimento da subjetividade. Por isso, tratar sobre movimentos da subjetividade do professor que expressa criatividade no trabalho pedagógico é um grande desafio, que exige cuidado no processo construtivo-interpretativo e que somente se torna possível, ao considerarmos o que afirma González Rey (2011b, p. 84):

\begin{abstract}
A ideia de configuração subjetiva nos permite gerar inteligibilidade sobre um sistema subjetivo em movimento ao qual só conseguimos acessar de forma progressiva na medida em que a pessoa vai se adentrando nas suas reflexões e considerações, que por sua vez constituem fontes de informação sobre os processo e sentidos subjetivos que de forma permanente são produzidos nessas configurações sobre as quais a própria pessoa não tem nem pode ter uma representação consciente.
\end{abstract}

Pautadas nessas colocações do autor, aproximamo-nos do estudo dos movimentos na subjetividade individual da professora Ananda, recorrendo aos seus processos reflexivos acerca de sua prática pedagógica. Assim, voltamo-nos para o relato que a professora Ananda fez acerca de duas grandes experiências pedagógicas que julgou serem merecedoras de premiação (instrumento de pesquisa elaborado pela autora).

Em um desses relatos, Ananda expôs uma experiência que ocorreu quando atuou em uma turma de $1^{\text {a }}$ série (ensino fundamental de oito anos), de uma instituição privada de 
ensino. Contou que fez a seleção de um livro para leitura com os alunos: "Menino no Espelho", do autor Fernando Sabino. Nesse livro, ele faz algumas narrativas de sua infância, e segundo Ananda, “é um livro super 'gostoso' de ler”.

A partir do enredo, trabalharam diversas atividades educativas, como: ampliação do vocabulário, construção de palavras presentes na leitura (escrita), interpretação de certos trechos, painel de palavras descobertas, desenhos (livro com poucas imagens), procura pelo significado de palavras desconhecidas, dentre outras. À medida que avançavam nas narrativas, os estudantes se interessavam mais e muitos solicitaram aos pais que comprassem o livro. Essa situação, aliada à participação ativa dos estudantes nas atividades propostas, foi considerada pela professora como indicativo da satisfação das crianças com a leitura, ao demonstrarem gostar das atividades. Para Ananda: "Eles cresceram muito! Eles riam muito! Gostavam de ouvir as histórias!”.

No decorrer dessas atividades com base na leitura do livro, Fernando Sabino veio à Brasília, para uma apresentação do filme "O Homem Nu". Ananda solicitou aos pais e à direção da instituição a ida de seus estudantes para essa apresentação, com a intenção de que eles conhecessem o autor. Outras professoras quiseram levar os seus alunos. No local, a visita de tantas crianças desorganizou o evento, pois quase todas levaram os seus livros para serem autografados pelo autor. Apesar disso, Ananda disse que Sabino ficou encantado com as crianças, fez os autógrafos solicitados e perguntas acerca do trabalho pedagógico desenvolvido pela professora. Depois, solicitou contato com a instituição, com a turma de Ananda, e enviou outro livro nominal para cada aluno, já autografado. Fizeram, ainda, cartas, que foram trocadas entre alunos e o autor. Para a professora: "Foi ótimo! Do nada, aconteceu um monte de coisa [...]. O que era apenas uma leitura, virou tudo isso! [...] Os meninos adoraram!”. Ela também: “Adoro essas folias, essas presepadas!” (risos). Disse que a motivação, a alegria das crianças a deixava motivada em seu trabalho pedagógico. Às vezes pensa muito acerca do que vai fazer, em termos de atividades educativas, em outras ocasiões, as ideias surgem, como nessa experiência.

Essa produção de ideias para o trabalho pedagógico nos indica que o andamento das atividades desenvolvidas pode ter sido significativo em termos de produção subjetiva, possibilitando que, no próprio processo de elaboração de atividades educativas criativas e sua realização, se constituíssem produções subjetivas que participaram da criatividade da professora. Era evidente a satisfação pessoal e profissional de Ananda com o processo de criação, elaboração e desenvolvimento do trabalho pedagógico, aspecto observado, 
também, em outros relatos de experiências significativas na trajetória profissional da professora.

Nessa situação, em especial, interpretamos que as ações educativas propostas por Ananda, incluindo uma visita em uma apresentação que não se relacionava diretamente ao livro, foram viáveis pelo exercício de sua condição de sujeito no trabalho pedagógico e pela produção subjetiva que se articulava em configurações subjetivas. Mas que, as próprias ações elaboradas e realizadas acerca do livro, possibilitaram uma produção de sentidos subjetivos relacionados ao trabalho pedagógico, à sua criatividade no planejamento das ações pedagógicas, bem como, às relações com as crianças.

Essa forma de compreender as produções subjetivas que se constituíram em Ananda nos aproximam das afirmações de Mitjáns Martínez (2012b, p. 95) quando aborda a aprendizagem criativa. Para a autora: "a produção de sentidos subjetivos favorecedores de geração de novidade que recursivamente 'alimentam' essa forma de aprendizagem" se constitui como uma das características dessa aprendizagem. No caso da professora, entendemos que a produção de sentidos subjetivos vinculados à satisfação pessoal, à realização profissional exitosa daquelas ações criativas elaboradas por ela, repercutiu em sua criatividade no trabalho pedagógico, "alimentaram" sua própria expressão criativa.

Em outras palavras, a produção de sentidos subjetivos no curso dessas ações novas e com valor para a aprendizagem dos alunos integrou sua criatividade no trabalho pedagógico, movimentando-a em prol dessa expressão criativa. Essas produções subjetivas repercutiram na subjetividade individual de Ananda, essencialmente, na constituição de sentidos subjetivos relacionados ao prazer em atuar como professora, à sua satisfação com a profissão, ao seu compromisso profissional, os quais integravam o trabalho pedagógico como núcleo subjetivo, participando de sua criatividade, em sua forma de subjetivar a profissão.

Entendemos que a articulação entre os processos de criação e o reconhecimento social desse trabalho pedagógico participou, ainda, do desenvolvimento de recursos subjetivos que integravam sua autoria, o seu protagonismo no trabalho pedagógico, como a flexibilidade em modificar o que foi planejado em decorrências das situações que se formavam e sua autoconfiança em colocar-se diante de outros profissionais. Colaborava para que a criatividade no trabalho pedagógico de Ananda repercutisse no movimento da subjetividade individual da professora, em produções subjetivas relacionadas à sua condição de sujeito, assim como, na subjetividade social da instituição. 
No curso dessa ação educativa, os sentidos subjetivos associados à sua criatividade no trabalho pedagógico possibilitaram o fortalecimento de sua condição de sujeito na sua prática profissional, organizando sentidos subjetivos constituídos no curso da própria experiência. Isso evidencia que "[...] a ação é uma fonte permanente de produção de sentidos subjetivos" (GONZÁLEZ REY, 2007b, p. 128), o que nos permite a compreensão de que o desenvolvimento de sentidos subjetivos ocorre por meio de uma "[...] processualidade que não é apenas intrapsíquica, mas também integra a ação e os diferentes sistemas de relações do sujeito, assim como a organização da vida social [...]” (GONZÁLEZ REY, 2007b, p. 129).

No processo construtivo-interpretativo, consideramos que essa e outras experiências criativas de Ananda no trabalho pedagógico, se relacionam ao que Geandra Santos (2010, p. 16) afirmou acerca das mudanças subjetivas do professor: para tanto se faz necessário produção de "[...] sentidos subjetivos favoráveis à relação e responsabilização com os alunos, e torna-se significativa, somente se for constituída por uma organização subjetiva com capacidade generativa e pelo exercício expressivo da condição de sujeito.”.

No caso de Ananda, à medida que suas produções criativas geravam a satisfação dos alunos e o seu avanço no processo de aprendizagem, fortalecia-se o intuito de elaborar novidades com valor para o processo de aprendizagem e desenvolvimento dos estudantes, atualizando os processos subjetivos que participavam de sua criatividade no trabalho pedagógico.

Por outro lado, no curso da pesquisa, entendemos que esse processo criativo no trabalho pedagógico possibilitava uma produção subjetiva que gerava em Ananda condições favoráveis à produção de alternativas próprias, à autonomia em sua prática profissional. E mais, mobilizava e atualizava suas (re) configurações subjetivas, núcleos subjetivos vinculados tanto ao trabalho pedagógico criativo, como a sua autovaloração, a profissão - ser professora, como também, sua condição de sujeito. Ou seja, sua expressão criativa no trabalho pedagógico tinha um valor para a própria Ananda, para o seu funcionamento subjetivo.

Como discutido em outra seção, compreendemos que havia em Ananda um funcionamento subjetivo caracterizado como criativo, conforme define Mitjáns Martínez (2009), um modo de lidar com as situações, com a vida e com sua profissão marcado pela geração de alternativas próprias e autônomas. Esse funcionamento gerava condições subjetivas que viabilizaram a constituição de uma expressão criativa no trabalho pedagógico. Nesta, por sua vez, se constituíam produções subjetivas, decorrentes dos processos de 
subjetivação de sua prática profissional criativa, que também repercutiam nesse funcionamento, fazendo com que a expressão criativa adquirisse valor para Ananda, bem como para o movimento na subjetividade individual da professora.

Nesse processo, reconhecemos o que afirma Mitjáns Martínez (2012a, p. 105):

Na medida em que a subjetividade se constitui e se desenvolve esta vai participando
da configuração dessas influências, constituindo-se em elemento ativo da sua
própria constituição e desenvolvimento. Desta forma, as experiências e influências
que adquirem potencial valor para o desenvolvimento subjetivo são aquelas que são
subjetivadas, aquelas em relação às quais se gerem sentidos subjetivos.

O conjunto de informações apresentado ao longo da construção das informações nos permitiu formular a hipótese de que o funcionamento psicológico criativo de Ananda participava de seu movimento subjetivo. E favorecia uma flexibilidade, uma crença em si mesma, uma abertura para o novo, que envolvia não apenas o seu campo de atuação profissional, mas suas relações para além da docência, suas atividades pessoais, sua forma de se colocar diante dos desafios, dos conflitos, da vida.

Assim, no estudo das inter-relações entre a criatividade no trabalho pedagógico e a subjetividade da professora Ananda, consideramos que havia recursividade entre os diferentes processos que configuram essa expressão criativa e o movimento em sua subjetividade. Isto é, os núcleos subjetivos que integravam sua criatividade no trabalho pedagógico, como autovaloração, a profissão - ser professora, a relação com os alunos, bem como o exercício da condição de sujeito da professora, se atualizaram a partir da produção de sentidos subjetivos que se constituíam no curso do próprio trabalho pedagógico criativo.

Tal produção de processos simbólicos e emocionais repercutiu nas produções subjetivas, o que gerou processos de movimento, atualização de sentidos subjetivos que constituíam suas configurações subjetivas relacionadas ao trabalho pedagógico criativo. Em outras palavras, no caso de Ananda, não identificamos mudanças subjetivas em decorrência do trabalho pedagógico criativo, mas sim movimentos em sua organização subjetiva, o que relacionamos ao próprio funcionamento psicológico criativo da professora.

\subsubsection{Considerações parciais acerca do caso da professora Ananda}

O processo construtivo-interpretativo desenvolvido no caso da professora Ananda nos possibilitou construções fundamentais a respeito dos objetivos desta pesquisa, as quais apresentamos de modo sintético neste momento. Compreendemos, no curso da pesquisa, que a professora organizava o seu trabalho pedagógico de modo que a produção de novidades com 
valor para a aprendizagem dos alunos caracterizava diferentes aspectos da dinâmica educativa. A sua criatividade marcava suas principais ações educativas. Estas, por sua vez, eram singularizadas, situavam-se em um contexto real de relações com os estudantes.

Ressaltamos, no estudo, sua criatividade nas relações professor-aluno e no clima comunicativo-emocional; na organização do processo de ensino-aprendizagem; na formulação e seleção dos objetivos de aprendizagem; nas estratégias e métodos de ensino. Dessas ações educativas participavam diferentes processos subjetivos em sua criatividade no trabalho pedagógico, quais sejam:

a) a forma como Ananda subjetivou o papel do professor - como responsável por pensar e estruturar o trabalho pedagógico;

b) a subjetivação do aluno, que tinha um lugar na dinâmica educativa, uma participação ativa;

c) a subjetivação da aprendizagem como uma construção que estava além da reprodução do conhecimento, abrangia a compreensão do tema em pauta;

d) a forma como a professora subjetivava a função social da educação. Para ela, os processos educativos precisavam favorecer a formação integral dos estudantes;

e) a subjetivação de conhecimentos específicos que a professora teve acesso ao longo da sua formação profissional, destacando-se em sua prática educativa a mobilização daqueles conhecimentos adquiridos em processos de formação em serviço. Tais conhecimentos foram subjetivados por Ananda no curso dos processos de formação a que teve acesso e se relacionavam a outros campos de interesse pessoal da professora, como filosofia, literatura, educação matemática e arte.

Além desses processos subjetivos, no caso de Ananda, consideramos que havia relações personalizadas entre a docente e os seus estudantes, as quais favoreciam a constituição de sentidos subjetivos que participavam de sua criatividade no trabalho pedagógico. Para essa professora, o aluno era um outro social que oportunizava novos desafios e outras necessidades pedagógicas, que implicavam a produção de novidades com valor para sua aprendizagem e desenvolvimento.

Compreendemos, também, que nessa professora a imaginação constitui-se como um recurso subjetivo, o qual perpassava o planejamento do trabalho pedagógico, antecedia sua realização e se expressava na produção de ideias a respeito das atividades educativas elaboradas por ela. 
Em seu trabalho pedagógico, a criatividade se revelava em práticas de ensino caracterizadas por sua autoria e seu protagonismo, bem como por sua intencionalidade pedagógica. Aspectos esses que relacionamos ao exercício da condição de sujeito em sua prática profissional. Dentre os núcleos subjetivos que integravam sua expressão criativa, estavam aqueles vinculados à sua autovaloração, relação com os alunos, família e profissão. Esse último, considerado como tendência orientadora de sua personalidade.

Entendemos ainda que, em Ananda, a dimensão instrumental da criatividade decorria de um funcionamento psicológico criativo, que lhe possibilitava propor alternativas autônomas e singulares. Em outras palavras, a criatividade se mostrou em sua dimensão funcional. Esse funcionamento específico, atrelado aos sentidos subjetivos constituídos a partir do trabalho pedagógico criativo, possibilitava uma produção subjetiva que gerava o movimento de núcleos subjetivos e o exercício da sua condição de sujeito. Por outro lado, consideramos que esse processo de autoria e protagonismo de Ananda no trabalho pedagógico foi possível por meio de recursos subjetivos constituídos ao longo de sua história de vida, das relações sociais em outros espaços e de processos subjetivos diversos.

\subsection{O caso da professora Júlia}

\subsubsection{Quem é a professora Júlia? Onde atua? Informações iniciais}

Júlia nasceu na região Nordeste do Brasil e possuía vinte e nove anos no período da pesquisa. Era casada e não tinha filhos. Veio morar em Brasília em 2008, quando seu esposo foi transferido, pela instituição em que trabalhava, para essa cidade.

Formou-se em Pedagogia em uma universidade federal no ano de 2006 e concluiu especialização em Psicopedagogia em 2012. Iniciou sua atuação profissional em sua cidade de origem como servidora pública do Ministério Público. Foi em Brasília que ingressou no magistério, atuando primeiramente como professora de contrato temporário da Secretaria de Educação do Distrito Federal - SEDF. No ano seguinte, foi aprovada no concurso para professor efetivo dessa Secretaria.

Em sua trajetória profissional, atuou como coordenadora pedagógica de quarto e quinto ano, supervisora pedagógica e professora de terceiro, segundo e primeiro ano do ensino fundamental. Era o segundo ano que estava na instituição educativa e, também, o segundo ano em que atuava como professora do primeiro ano (ensino fundamental de nove anos). 


\subsubsection{Contexto da instituição educativa onde Júlia atuava}

No ano da pesquisa, Júlia atuava em uma instituição educativa que atendia exclusivamente aos anos iniciais do ensino fundamental. Essa instituição se localizava em uma região administrativa do Distrito Federal considerada de classe média baixa. Lá havia quatro salas de aula. No turno matutino, tinham turmas de segundo, terceiro, quarto e quinto ano. No vespertino, turmas de primeiro, segundo, terceiro e quarto ano.

A instituição possuía um grande espaço ao fundo dos prédios, onde havia um banco de areia, uma quadra de esportes e área com gramado. As salas de aula eram amplas, com carteiras em tamanho padrão. Na sala de Júlia, tinha um relógio de parede; alfabeto ilustrado (letras e imagens representando um objeto com aquela letra inicial); um cartaz com números e quantidades em cima do quadro; um quadro negro e, em uma parte dele, um quadro branco fixado; dois armários baixos; dois armários grandes para os professores (um de cada turno); um pequeno aparelho de som; e duas estantes para guardar materiais diversos, como livros, atividades realizadas pelos alunos, dentre outros.

O ensino organizava-se em ciclo para o primeiro, segundo e terceiro ano do ensino fundamental e, em seriação, para as turmas de quarto e quinto ano, o que seguia as orientações da SEDF. De modo geral, foi observado que a presença de apenas uma turma de cada ano dificultava a interação entre os professores e os processos de troca acerca das experiências pedagógicas. Ainda assim, foram formulados projetos educativos que envolviam todas as turmas, como o presenciado durante a pesquisa que se referia a valores (amizade, amor, dentre outros).

Na instituição, havia um aparelho de data show, adquirido no ano de 2013, que poderia ser utilizado pelos profissionais. Havia uma pequena sala para as atividades de informática, com alguns computadores e a presença de uma estagiária (profissional cedida pelo governo como contrapartida a um programa de financiamento de acesso ao ensino superior), uma coordenadora pedagógica e uma professora readaptada que participava ativamente do projeto interventivo criado pelos profissionais da instituição. Na biblioteca, atuava uma professora que direcionava o trabalho realizado semanalmente com cada turma, sendo a metade dessa turma encaminhada em horários específicos para atividades elaboradas e realizadas por ela.

No momento do estudo, Júlia era a professora do primeiro ano do ensino fundamental, e sua turma tinha, em torno de, vinte e oito alunos. Eles tinham seis anos de idade, alguns frequentaram, antes, a educação infantil. Foi no contexto dessa instituição que estudamos a 
expressão criativa de Júlia, que, com forte compromisso profissional, empenhava-se em oportunizar um processo educativo que se ampliava para além da alfabetização, envolvia o acesso a diferentes conhecimentos de mundo.

\subsubsection{Os instrumentos da pesquisa com a professora Júlia}

Quadro 10 - Os instrumentos da pesquisa com a professora Júlia

\begin{tabular}{||l||l||}
\hline \multicolumn{1}{|c|}{ Instrumentos e procedimentos da pesquisa } & \multicolumn{1}{c||}{ Data } \\
\hline \hline Cenário de pesquisa & Junho/2013 \\
\hline Observações no cotidiano escolar e conversas informais & Julho/2013 a outubro/2013 \\
\hline Redação 1: O sentido da minha vida & Agosto/2013 \\
\hline Entrevista 1: Trajetória de vida, pessoal e acadêmica & Agosto/2013 \\
\hline Túnel do tempo & Agosto/2013 \\
\hline Completamento de frases & Setembro/2013 \\
\hline Redação 2: O sentido de ser professor & Setembro/2013 \\
\hline Entrevista 2: Trajetória profissional & Setembro/2013 \\
\hline $\begin{array}{l}\text { Análise documental: atividades educativas elaboradas, avaliações da } \\
\text { aprendizagem, currículo prescrito para o } \text { 1 }^{\circ} \text { ano e cartazes produzidos } \\
\text { por ela. }\end{array}$ & Durante as observações \\
\hline Duas grandes premiações & \\
\hline Entrevista 3: esclarecimento de informações & Outubro/2013 \\
\hline \hline
\end{tabular}

Fonte: a autora (2014)

4.2.4 Expressões criativas no trabalho pedagógico: a professora Júlia como sujeito de sua prática profissional

A compreensão da singularidade dos processos criativos nos conduz ao olhar particular para cada professor, bem como para as especificidades que caracterizam sua atuação docente. No caso da professora Júlia, entendemos, no curso do processo construtivo-interpretativo, que havia uma organização do trabalho pedagógico caracterizada por sua expressão criativa. Esta envolvia especialmente:

a) a construção de uma metodologia própria de ensino, a qual envolvia uma sistematização personalizada acerca do processo de alfabetização;

b) a ampliação do currículo prescrito pela instituição educativa, o que incluía acesso a diferentes conhecimentos de mundo;

c) a elaboração pessoal de atividades educativas utilizadas em seu trabalho pedagógico, as quais se articulavam aos recursos pedagógicos elaborados pela professora e a seleção de materiais relacionados ao tema em estudo; 
d) a imaginação como estratégia pedagógica privilegiada para abordar os assuntos em pauta e realizar as explicações.

Tais aspectos estavam articulados na dinâmica educativa que Júlia construiu com o grupo de estudantes que formava a sua turma. No cotidiano escolar, foi possível observar um trabalho pedagógico sistêmico e criativo, em que as novidades criadas pela professora tinham valor para o processo de construção de conhecimentos, a implicação dos alunos em sua aprendizagem e o nítido interesse que eles expressavam em participar das atividades propostas pela docente.

No curso das observações, interpretamos esse forte interesse dos estudantes com base no seu movimento em sala de aula, pelos comentários e falas espontâneas durante as atividades e a expressão de alegria que demonstravam ao realizar as propostas educativas oferecidas pela professora. Júlia indicou significativo empenho em oportunizar um processo de ensino que fosse, de fato, um meio para acesso aos conhecimentos históricos e culturais, e favorecesse o envolvimento ativo dos alunos.

Para tanto, mobilizava-se para a construção de uma metodologia própria de ensino, a qual abrangia uma sistematização personalizada a respeito do processo de alfabetização. Nessa metodologia, Júlia voltava-se para práticas de ensino que favorecessem a alfabetização, processo em que os alunos eram solicitados a observar as relações entre grafemas e fonemas, identificar possíveis relações entre a oralidade e a escrita, tentar alternativas de respostas para as questões que a professora lançava para a turma e expor suas hipóteses de escrita.

Compreendemos que tais práticas educativas seguiam uma estrutura de ensino elaborada pela professora para alcançar os objetivos de aprendizagem que ela concebia para os seus estudantes: a alfabetização e o letramento. Essa estrutura constituía-se por alguns momentos pedagógicos definidos previamente por Júlia, os quais, segundo nossa interpretação, indicavam uma sistematização personalizada acerca do processo de alfabetização.

O primeiro momento dessa estrutura de ensino referia-se a escolha de um livro literário que possibilitasse o trabalho com os conteúdos selecionados por ela. A professora contava essas histórias com entusiasmo, e os alunos, atentos, acompanhavam as leituras. Depois, Júlia explorava trechos do enredo, a sequência dos fatos e as personagens. Conduzia essa atividade a partir de perguntas, que levavam à retomada da história. 
Observamos que a docente aproveitava os dias destinados a ida à biblioteca para explorar a história, quando a professora desse local levava a metade da turma de alunos para atividades diferenciadas produzidas por ela. Júlia, assim, contava a história para um grupo reduzido de estudantes e repetia isso com o outro grupo, quando retornavam à sala de aula.

Do enredo, a professora selecionava algumas palavras para estudo da escrita padrão, as quais formavam um repertório ortográfico que integrava as atividades posteriores. No dia da história, Júlia solicitava a escrita espontânea dessas palavras, o que compreendemos constituir o segundo momento da sua metodologia de ensino. Para ela, essa atividade permitia o seu entendimento a respeito de como os alunos estavam nas hipóteses de escrita, constituindo uma forma de realizar o teste psicogenético proposto por Emília Ferreiro.

A partir da análise dos níveis da psicogênese, Júlia organizava as demais ações educativas da metodologia de ensino formulada por ela, as quais formavam o terceiro momento de sua estrutura de ensino. A professora elaborava as atividades educativas diferenciadas para os alunos, conforme sua "leitura" sobre os níveis de hipóteses de escrita que eles se encontravam. Para todos incentivava a escrita padrão; identificação dos fonemas e sua representação por meio dos grafemas; formação de frases com aquelas palavras selecionadas, mesmo que ainda não estivessem completamente alfabetizados; representação gráfica - desenhos - dessas palavras; reconto da história pelos próprios alunos aos seus familiares; construção de pequenos textos referentes ao resumo da história; interpretação e compreensão do texto.

Essa estrutura de ensino mantinha-se na dinâmica educativa, sendo as atividades modificadas em função dos conteúdos selecionados pela professora e de outras demandas, como foi observado no período da Copa das Confederações, festa junina, e, um passeio para uma exposição de obras artísticas agendada por outros profissionais da instituição. A professora incluía essas demandas em seu trabalho pedagógico, nos diferentes momentos que formavam sua metodologia de ensino.

Nesses momentos, Júlia oportunizava o contato com as palavras selecionadas em diversas tarefas educativas. Para ela: "A escrita é um ato de tomada de confiança” (Júlia, Túnel do tempo), o que justificava a importância dos estudantes tentarem escrever em situações e tarefas diferenciadas. A professora tinha clareza desse papel da escrita para a alfabetização e a incluía em diferentes momentos de sua sequência didática. A propósito, afirmou com satisfação: “[...] a rotina pedagógica que acontece na minha sala de aula hoje é uma coisa assim... que me orgulha muito[...]" (Júlia, Duas grandes premiações). 
Interpretamos que esse orgulho estava relacionado aos resultados que podia acompanhar no processo de aprendizagem de seus alunos e que lhe causavam satisfação com o trabalho pedagógico desenvolvido. Ao falar de suas experiências profissionais, comentou:

\begin{abstract}
Eu me sinto muito feliz com o resultado. Quando eu vi que o resultado foi... Eu, pelo menos, percebo que é um resultado bem diferente do que percebo em outros lugares. Eu acho que é uma experiência de sucesso. [...] Eu tenho muita coisa legal, mas até que ponto é digno de prêmio ou, é uma questão que se espera que se faça, que você execute na sua função. Então, digno de prêmio eu diria que essa rotina, porque comparando, eu vejo que é uma medida real de conseguir um resultado... (Júlia, Duas grandes premiações)
\end{abstract}

Júlia havia iniciado a sistematização dessa sequência pedagógica no ano letivo anterior, quando pela primeira vez, atuou na alfabetização. Com base nessa experiência, subjetivou os resultados que gostaria de alcançar em sua atuação profissional no primeiro ano ensino fundamental: a plena alfabetização de seus alunos num universo de letramento. A busca por esse resultado a mobilizava para a construção de atividades educativas que fossem novas e com valor para a aprendizagem dos alunos, bem como para a manutenção dessa sequência: “[...] Não é o desafio que me motiva. O que me motiva é o resultado", Júlia afirmou (Entrevista I).

Nessa perspectiva, consideramos que a sequência didática que a professora construiu estruturava a sua organização do trabalho pedagógico, formando uma metodologia própria de ensino. Essa metodologia era permeada por forte intencionalidade pedagógica, pelo intuito da professora em realizar uma ação educativa que viabilizasse novos níveis de aprendizagem e desenvolvimento dos alunos. Esse desejo de colaborar para a construção de conhecimentos por parte dos estudantes, por alcançar os resultados esperados por ela, mobilizava Júlia, instigava o planejamento do seu trabalho pedagógico, a produção das atividades educativas que iria realizar.

Alcançar os resultados esperados por ela, por meio de atividades produzidas na sequência que criou, lhe gerava, também, forte satisfação profissional, um prazer em ensinar. Ao escrever acerca do sentido de ser professora, afirmou: “O sentido do meu empenho vem dos meus alunos, são o meu combustível, mas sinto que quando não obtiver resultados, eu perderei esse encantamento e o sentido de ser professora" (Júlia, Redação II). Consideramos que a percepção da aprendizagem dos alunos oportunizava em Júlia a constituição de sentidos subjetivos relacionados à satisfação com o trabalho pedagógico, repercutindo, por sua vez, em seu interesse pela docência. 
Compreendemos que dessa satisfação com o trabalho pedagógico participavam processos simbólicos e emocionais que se constituíram ao longo de sua trajetória profissional. Implicavam, no momento da pesquisa, sua segurança emocional em manter a sequência didática, assim como, sua autoria como professora, seu protagonismo na organização do trabalho pedagógico. Ao falar acerca de quando iniciou essa sequência, comentou:

Eu entrei numa sala que tinha três grupos, um grupo que estava bem, dentro do
esperado para o segundo ano, um grupo que estava no meio termo, um grupo que
estava 'zeradasso'. Eu tinha um terço de cada. Eu lembro que fiquei desesperada,
ainda tinha uma criança que não enxergava. Eu falei: meu Deus! E ela ainda ficava
grudada em mim. Eu fiquei desesperada! Como é que eu trabalho com três grupos
tão distintos? Eram três necessidades completamente diferentes. [...] Eu pedi ajuda, e
me falaram: você tem que sentir a turma. Eu falei: já senti e agora? Eu chorava! Meu
Deus, a menina não está vendo nada! Eu ainda tinha que fazer o material para a
menina, eu lembro que ainda tinha que montar o material para a menina que não
estava enxergando, maior, que ela pudesse percorrer com o dedinho, maior. (Júlia,
Entrevista II).

Nesse trecho, exemplificamos a autoria de Júlia em seu trabalho pedagógico, a sua iniciativa em produzir atividades novas e com valor para a aprendizagem e desenvolvimento de seus alunos, sua condição de sujeito em sua prática profissional. Diante das diferentes necessidades educativas que a professora percebia em sua turma, das especificidades que os estudantes apresentavam, ela se mobilizou, procurou elaborar atividades pedagógicas que ampliassem as possibilidades de avanços em sua aprendizagem, segundo os grupos que identificou.

Interpretamos, assim, que a expressão criativa de Júlia no trabalho pedagógico decorria de demandas advindas do próprio cotidiano educativo, das necessidades educativas que se constituíam no sistema relacional entre ela e seus alunos. Isto é, das relações personalizadas que Júlia estabelecia com eles, do conhecimento que possuía acerca dos processos, dos momentos da aprendizagem de cada um deles e do seu forte intuito de colaborar para a construção de conhecimentos.

Essa construção relaciona-se à compreensão do aluno como um outro social que participa da criatividade no trabalho pedagógico do professor, por meio de suas demandas, de desafios e necessidades pedagógicas que oferece ao docente. O sistema relacional entre professores e estudantes, os vínculos afetivos entre eles, podem gerar a formação de motivos que, aliados à organização subjetiva do professor e a outros motivos, favorecem a produção de novidades com valor para a aprendizagem e desenvolvimento desses alunos, mobilizando o professor para sua autoria na organização do trabalho pedagógico. Nessa perspectiva, entendemos as colocações de Cunha (2005, p. 196): “[...] os professores produzem-se em função de relações que estabelecem principalmente com seus alunos, nesse 
caso, a relação entre tais sujeitos, docentes e alunos, se caracteriza como sendo de ensinoaprendizado [...]".

Compreendemos que desse processo de ensino-aprendizado surgem necessidades educativas que podem mobilizar o professor para sua expressão criativa, participando alguns dos conhecimentos adquiridos ao longo da formação docente. Júlia ao discorrer a respeito de sua sequência didática, afirmou, em vários momentos da pesquisa, que buscava incluir em seu cotidiano educativo os pilares que aprendeu no curso pró-letramento ${ }^{8}$, formação continuada que participou durante dois anos, um em língua portuguesa e outro em matemática. A professora nomeou tais pilares de língua portuguesa, como: leitura, produção textual, desenvolvimento da oralidade, apreciação da cultura escrita (percepção do sistema notacional, escrita alfabética, valorização dos contos e das fábulas) e sistematização (reflexão sobre a língua). Afirmou considerar, também, o que aprendeu a respeito do letramento matemático.

\begin{abstract}
A sequência tem que prever esses cinco momentos na semana, sempre. Então, ela tem que ter momentos de leitura, momentos de promover a escrita espontânea, ela tem que ter momentos de criação de hipóteses, ela tem que promover momentos de debates entre as crianças, que elas infiram, criem vínculo com aquilo. Tem que ter sempre atividades que forcem isso. (Júlia, Duas grandes premiações).
\end{abstract}

$\mathrm{Na}$ descrição realizada anteriormente acerca da metodologia de ensino da professora, percebemos o esforço para a incorporação desses pilares no seu trabalho pedagógico. Havia uma personalização, subjetivação das informações e conhecimentos específicos de tais campos (língua portuguesa e matemática) que foi possível a partir dos cursos que frequentou. Júlia entendeu os pilares expostos durante essas formações em serviço e, de modo intencional, os incluía em sua dinâmica pedagógica, nas atividades educativas que organizava. Compreendemos que esse aspecto diz respeito ao processo de ir além das informações oferecidas nos espaços de formação, ao uso personalizado desses conhecimentos em sua prática profissional.

Consideramos que tais conhecimentos específicos, de língua portuguesa e matemática, articulavam-se ao saber fazer, aos saberes experienciais construídos pela professora em sua atuação profissional, expressão de Tardif (2005, p. 53). Para o autor:

Os professores não rejeitam os outros saberes totalmente, pelo contrário, eles o
incorporam à sua prática, retraduzindo-os, porém, em categorias de seu próprio
discurso. Nesse sentido, a prática pode ser vista como um processo de aprendizagem
através do qual os professores retraduzem sua formação e a adaptam à profissão,
eliminando o que lhes parece inutilmente abstrato ou sem relação com a realidade
vivida e conservando o que pode servir-lhe de uma maneira ou de outra.

\footnotetext{
${ }^{8}$ Curso oferecido por formadores da Escola de Aperfeiçoamento dos Profissionais da Educação - EAPE em parceria com o governo federal - Ministério da Educação - e formadores de universidades públicas.
} 
No caso de Júlia, interpretamos que a incorporação daqueles conhecimentos específicos em sua prática foi possível porque houve a sua subjetivação, a personalização do aprendido durante os dois cursos de formação em serviço. Essa subjetivação é entendida como afirma Mitjáns Martínez (2012a), como a personalização, o questionamento, a reflexão própria acerca do que se estuda, a problematização, a geração de ideias que estão para além do dado. Esses processos estavam vinculados ao entendimento da professora de que aqueles pilares poderiam auxiliá-la a alcançar os objetivos de aprendizagem propostos para os seus alunos.

Reconhecemos, assim, que os processos de formação em serviço vinculados aos campos de interesse da professora repercutiram e participaram de sua expressão criativa no trabalho pedagógico. Permitiram a professora conhecimentos que possibilitaram a produção de novidades com valor para os processos de aprendizagem e desenvolvimento dos alunos e, com isso, a constituição de uma metodologia própria de ensino. No momento de ingresso no primeiro ano do ensino fundamental, aqueles interesses estavam relacionados às áreas de alfabetização e letramento matemático, campos que foram abordados nos dois cursos de formação.

Apesar dessa relação entre sua prática profissional e tais cursos, Júlia fez críticas significativas a respeito das propostas de formação continuada oferecidas pela Secretaria de Educação. Para ela, essa formação é fundamental, entretanto, afirmou:

[...] Eu acho que são ilusórias, como metade dos programas da secretaria são ilusórios. Eu não vejo a formação como suficiente para mudar a realidade que existe hoje na secretaria. Eu vou para a formação, acho fantástico no campo conceitual, você pega o material para ler [...] Mas no campo de postura, de ação, eu acho falho. Mas não é um problema só da formação, é um problema da formação inicial também. Aquela coisa, vamos formar o ser humano consciente, dialógico, o pesquisador, que na sua prática ele vai ter uma postura crítica. Isso é um grande contra-senso. A faculdade pouco bebe da prática para promover as primeiras reflexões, posturas. (Júlia, Entrevista I).

No caso de Júlia, compreendemos que, embora ela faça uma série de críticas à formação docente, sua prática educativa se beneficiava de conhecimentos pedagógicos que teve acesso ao longo de seus estudos no campo da educação. No seu cotidiano educativo, a professora lançava mão de certos conhecimentos, em especial, daqueles subjetivados nos processos de formação em serviço, e que se relacionam aos seus campos de interesses.

As críticas apontadas por Júlia se estenderam, também, à sua formação inicial, no curso de Pedagogia:

Minha formação não teve nada direcionado para sala de aula! Assim, de forma sistemática, de uma forma [...]. A gente teve: vamos estudar rotina, plano de aula, plano de curso, sempre no campo do teórico, dialético, dialógico... Nunca no campo 
prático. Eu tive poucos professores com uma abordagem prática. E até aqueles que tinham uma abordagem prática, era mais no campo de provocação, reflexão, do que necessariamente preparar para o exercício da sala de aula. Inclusive, eu acho que os cursos não preparam. (Júlia, Entrevista II).

Em outros momentos da pesquisa, a professora comentou que gostou muito da sua graduação, que nesse processo envolveu-se com a educação, mas que o curso é muito diferente da realidade da sala de aula e que a sua formação em Pedagogia não a auxiliou em sua atuação profissional. Hipotetizamos que a abrangência do curso e a diversidade de campos de atuação do pedagogo podem ter favorecido para que a graduação não fosse, para Júlia, um momento de formação voltado à prática docente em sala de aula. Tanto que ela afirmou: “[...] Quando eu cheguei em Brasília, que eu passei como contrato temporário, e tive que entrar em sala, foi uma ansiedade muito grande! Eu falei: e agora?” (Júlia, Entrevista II).

Embora, consideramos que o seu interesse em ampliar o currículo prescrito proposto pela instituição educativa pode ter relação com essa formação inicial. Para Júlia era necessário que os conteúdos de ensino e aprendizagem favorecessem o acesso a conhecimentos de mundo. No cotidiano pedagógico, a professora empenhava-se em oferecer informações, conhecimentos acerca de outros países e outras culturas.

Júlia fazia isso por meio de vídeos que abordavam: brincadeiras típicas de outras regiões, que os estudantes observavam e brincavam junto com a professora; apresentações musicais com repertórios em outras línguas; danças tradicionais de alguns lugares; o ensino de pequenas expressões em língua estrangeira (presenciamos em Espanhol e Italiano), dentre outros. Articulava o estudo de tais aspectos ao processo de alfabetização, preocupando-se em oferecer aos alunos a possibilidade de se aproximarem de outros espaços culturais e sociais.

Selecionamos, para exemplificar as relações entre a alfabetização e essa ampliação do currículo prescrito, uma situação pedagógica que ocorreu no período da Copa das Confederações (junho e julho de 2013). Naquele momento específico, a professora inseriu em seu planejamento o estudo de alguns países que participaram dessa competição.

No dia primeiro de julho, a aula iniciou-se com a revisão do mapa mundi, com o nome de continentes e oceanos. Objeto esse que estava exposto no quadro negro à frente dos estudantes. A professora retomou, com a participação dos alunos, os lugares que tinham "visitado", falaram: Brasil, Nigéria, Austrália, Espanha. Utilizava-se de expressões como: “coloquem os cintos de seguranças, vamos viajar!”.

Após esse momento, assistiram a um vídeo com dança espanhola (projetado com aparelho de data show) e tentaram dançar. Em seguida, Júlia pegou o mapa novamente e avisou que iriam se despedir da Espanha, mas ficariam na Europa, conheceriam outro país 
cujo nome iniciava com a letra i: a Itália. Prosseguiu com explicações orais diversas, que envolviam assuntos como: a localidade (continente Europeu) desse país e comidas típicas (pizza, massas) daquela região. Durante suas explicações, uma criança pediu para ela falar italiano. A professora respondeu que não sabia, mas que iria trazer algumas palavras para que aprendessem. Depois, outro aluno insistiu. Ela, então, explorou qual poderia ser a língua falada na Itália. Alguns alunos disseram italiano, outros, mostraram-se confusos. Júlia perguntou como se falava bom-dia em espanhol, disse e os estudantes repetiram. Em seguida, pronunciou bom-dia em italiano, o que também foi repetido pelos alunos.

A professora mostrou em sala de aula outro vídeo com uma dança italiana. Uma criança perguntou se iriam dançar, respondeu que fariam isso na quinta-feira daquela semana. Antes, iriam ouvir uma música em italiano com que ela sempre se emocionava quando escutava. Seguiu com explicações a respeito da vida do cantor Andrea Bocelli (nascimento, formação, casamento). Expôs o vídeo e, durante sua exibição, valorizava positivamente o fato de o cantor ser deficiente, ter superado dificuldades e ser cantor de sucesso. Fez relações com outros temas, como: deficiência visual, relembrando um vídeo que assistiram no início do ano sobre necessidades especiais e o que era uma orquestra.

Depois do intervalo, retomou o estudo acerca da Itália. Comentou que trouxe uma história escrita por um autor italiano: Pinóquio. Júlia conduziu a leitura do livro, e, em seguida, explorou com os alunos o enredo, personagens e o que poderiam aprender com o Pinóquio. Nas carteiras, distribuiu folhas com seis retângulos para os estudantes, e ressaltou que iriam escrever "do seu jeito". Ditou as palavras que faziam parte da história: fada, baleia, raposa, menino, Gepeto, Pinóquio. Orientava para, depois de tentarem escrever, desenhar. Passava nas carteiras e elogiava os alunos, que sorriam para ela em demonstração de que tinham gostado de seus elogios.

Nos dias seguintes, a professora introduziu o tipo de texto "biografia" a partir das informações que expôs para os alunos acerca da vida de Andréa Bocelli, continuou o estudo das palavras referentes à história de Pinóquio e ao enredo. Explorou outros aspectos culturais da Itália, inclusive a dança italiana que havia apresentado antes. Com isso, ampliou a possibilidade de aprendizagem dos alunos para aspectos culturais que estavam distantes da realidade social em que viviam. Apresentou conteúdos que, por seu caráter cultural, extrapolavam as prescrições curriculares para o primeiro ano do ensino fundamental.

Interpretamos que esse movimento intencional de Júlia para ampliar o acesso aos conhecimentos por parte de seus estudantes relacionava-se à forma como subjetivou a 


\title{
função social da educação. Para essa professora, sua ação educativa poderia auxiliar os
} alunos a ter acesso a uma gama de conhecimentos que lhes daria a oportunidade de mudanças sociais. Em outras palavras, a educação formal poderia viabilizar transformações sociais e ampliar a participação cultural daquelas crianças, de classe média baixa, nos diferentes espaços sociais.

Essa construção se relaciona ao interesse da professora e a sua intencionalidade consciente em favorecer aos seus estudantes o contato com conteúdos culturais. Ao falar a respeito do seu trabalho pedagógico, Júlia afirmou:

\begin{abstract}
Eu estou oportunizando pra essa criança um aprendizado que talvez ela nunca tenha acesso. Isso é coisa que é função da escola, e a gente peca muito. A gente acaba indo no reducionismo ali. Quando eu vou pra um curso e tem aqueles joguinhos. Tudo bem, o joguinho é ótimo. Mas é uma coisa pontual, a gente pode oportunizar pra essas crianças conhecimento de mundo. O que separa as crianças de uma escola pública pra uma particular. As crianças da escola particular são imersas num universo de letramento brutal desde pequena. [...] A gente acaba privando, privando de um jeito, em uma dimensão, que a gente acaba determinando desde já a distinção social. Eu quero que o menino saia sabendo a consciência fonológica, fazendo frases, palavrinhas. Ótimo! Mas isso vai ser suficiente pra ela ter oportunidade de brigar por um futuro, de repente, diferente? Não! (Júlia, Túnel do tempo, grifo nosso).
\end{abstract}

Nesse trecho, consideramos que a professora expressou sua preocupação de ir além do processo de alfabetização, o que foi presente também em outros momentos da pesquisa. Júlia conferia importância social aos espaços educativos, como meios para que os alunos tivessem condições de mudar sua realidade social. Isso a mobilizava, a fazia pensar em novidades com valor para o processo de aprendizagem e desenvolvimento de seus alunos, a buscar vídeos, a fazer pequenas pesquisas, se aproximar de outros espaços culturais e a aprender expressões em outras línguas para poder ensinar.

Compreendemos, portanto, que a forma como a professora subjetivou a função social da educação participava da sua expressão criativa no trabalho pedagógico. E, que nesse processo subjetivo integravam-se sentidos subjetivos que se constituíram na sua própria história de vida. No caso de Júlia, entendemos, no estudo da sua subjetividade individual, como a educação formal implicou em processos de mudanças sociais, na possibilidade de ter condições financeiras que outros familiares não tiveram.

Interpretamos que, por isso, era tão importante para ela oferecer outros conhecimentos, outros conteúdos para além dos prescritos. Esse aspecto se relacionava, ainda, à forma como Júlia subjetivou o papel do professor: como responsável por ampliar as oportunidades de aprendizagem e, com isso, colaborar para a função social da educação, tal como ela subjetivou. Realizamos essa construção com base no seu intuito de oportunizar o acesso a 
diferentes conteúdos, à ampliação do currículo prescrito na instituição educativa, à sua busca por favorecer a compreensão dos diversos temas abordados em suas aulas e à sua condição de sujeito em sua prática profissional.

Júlia se empenhava nessa tarefa de oferecer outros assuntos e buscava, intencionalmente, articular diferentes áreas do conhecimento em seu trabalho pedagógico. Ao comentar sobre como organizava sua sequência didática, a professora explicou:

\footnotetext{
Eu gosto que a história me dê subsídios para outras coisas. Então, João e o Pé de Feijão, trabalhei o ciclo de vida do feijão, trabalhei o feijão, trabalhei o vegetal. Já puxei para ciências, o ciclo de vida dos vegetais, o feijão cresceu, eles levaram para casa. A importância do sol, da água, senão tiver, o feijão não vai crescer [...] $\mathrm{Na}$ história da Cinderela nós trabalhamos o relógio, o tempo, o que é meia noite, medidas de tempo. [...] Cada história em puxo para um campo de conhecimento. [...] A matemática também, situações problemas com as personagens, envolvendo a história. (Júlia, Duas grandes premiações, grifo nosso).
}

Essas afirmações de Júlia se relacionam ao que observamos durante a pesquisa, ela articulava ao enredo da história a uma série de conteúdos que extrapolavam os processos de codificação e a decodificação. Para exemplificar a afirmativa, apresentamos, também, o período em que selecionou, meses depois, a história: A Pílula Falante, de Monteiro Lobato. Solicitou, nessa história, a escrita espontânea de algumas palavras: Emília, Narizinho, doutor Caramujo, caranguejo, tia Nastácia, Dona Benta, papagaio.

A inclusão de outros assuntos foi posterior ao momento da escrita espontânea e da indicação da norma padrão referente àquelas palavras. Acrescentou conteúdos que estavam para além das diretrizes curriculares previstas para o primeiro ano, como pode ser analisado no currículo prescrito destinado ao primeiro ano do ensino fundamental (SEDF). As atividades envolveram as diferenças entre caracol e caramujo, o habitat natural de tais animais (ambientes terrestre e aquático), sua atuação dentro do bioma (hábitos, alimentação) e consequências de sua presença para a saúde humana. Para tanto, a professora selecionou vídeos explicativos que possibilitavam a apresentação acerca de tais conteúdos. Durante a aula de informática explorou, ainda, a escrita padrão de cada um desses animais no que chamava de "preguicinha eletrônica".

É possível compreender, então, que essa implicação de Júlia para ampliar as prescrições curriculares repercutia em sua criatividade na elaboração de atividades educativas utilizadas em seu trabalho pedagógico, caracterizando a elaboração de recursos pedagógicos e a seleção de materiais relacionados ao tema em estudo. A "preguicinha eletrônica", por exemplo, referia-se à modificação de uma estratégia pedagógica conhecida entre os profissionais da alfabetização, chamada apenas de preguicinha. Nessa atividade são 
exploradas, gradativamente, as letras que compõem as palavras, em uma análise fonética da escrita.

Júlia elaborou em Power Point sua própria análise fonética, colocava em destaque a letra inicial da palavra estudada e apresentava várias imagens que continham essa letra. Apresentava a letra seguinte e, com a participação dos estudantes, eliminavam as imagens que não continha a sílaba formada. Pouco a pouco surgia a escrita da palavra a ser estudada, sendo eliminadas as figuras que não correspondiam às sílabas formadas. As imagens eram selecionadas por ela previamente, em geral, relacionavam-se ao enredo da história escolhida antes, movimentavam-se na apresentação, e as sílabas, escritas com cores diferentes.

Outra atividade produzida por Júlia foi o estudo diário de operações matemáticas, com a representação do pensamento matemático por diferentes vias: desenhos, construção de tabelas e gráficos. $\mathrm{Na}$ contagem do número de alunos presentes, a professora solicitava auxílio de dois estudantes, os quais deveriam contar o número de meninos e meninas. Para esse registro, Júlia utilizava diversas formas: montava tabelas, explorando o que eram linhas, colunas, e a partir delas simulava situações em que os alunos deveriam formar duplas ou pares. Em outros momentos, formava gráfico de barra e abordava conceitos relacionados. Elaborava pequenas situações-problema que requeriam operações de adição e subtração.

Notamos, claramente, que era a professora quem organizava, planejava e produzia as atividades educativas realizadas com seus alunos. Fazia isso com base nos conteúdos que pretendia trabalhar e nos diferentes momentos do processo de aprendizagem em que estavam. No curso das observações, não presenciamos o uso de livros didáticos ou atividades elaboradas por outros profissionais.

Observamos, também, que Júlia diferenciava algumas atividades para atender as necessidades educativas dos estudantes de sua turma. A atividade chamada por ela de "ficha conflito", por exemplo, era elaborada segundo as hipóteses de escrita dos alunos. Por isso, continham três diferenciações entre elas, apesar de contemplarem as mesmas palavras: em uma delas, havia imagens representando as palavras e algumas letras, sendo solicitado aos alunos que preenchessem os espaços em branco com as que estavam faltando. Em outra continha, além das imagens, algumas sílabas e espaços em branco, que deveriam ser completados com as sílabas que estavam ausentes. Um terceiro tipo continha espaços em branco correspondentes às letras que compunham as palavras. No momento de distribuir as atividades, a entrega ocorria de acordo com a avaliação da professora acerca do momento de aprendizagem de cada aluno. 
Compreendemos, no curso da pesquisa, que as atividades realizadas pelos estudantes da turma de Júlia eram elaboradas a partir da compreensão da professora a respeito da aprendizagem de cada um deles. Era ela a autora das atividades educativas e da organização curricular desenvolvida com seus estudantes. A professora mostrou-se protagonista das escolhas e produções educativas e autora de seu trabalho pedagógico.

Relacionamos essa autoria ao exercício da condição de sujeito em sua atuação, sua prática profissional. Essa construção se pauta nas afirmações de González Rey (2011a), que define o sujeito como uma forma qualitativamente diferenciada de manifestação, de atuação das pessoas nos contextos sociais de que participam. O exercício da condição de sujeito, para o autor, relaciona-se à possibilidade desse indivíduo abrir espaços próprios de práticas e de processos de subjetivação nos diferentes grupos e instituições nos quais atua, o que percebemos no caso de Júlia por meio da sua autoria, do seu protagonismo no trabalho pedagógico.

Esse protagonismo, por vezes, se contrapunha às ações educativas legitimadas e aceitas nos espaços escolares da maioria das instituições educativas, inclusive, da que Júlia atuava. Em muitas situações, predomina a passividade dos profissionais em sua prática educativa, que se revela na aceitação do currículo indicado nos livros didáticos, na necessidade de atividades copiadas de coleções didáticas, de listas de exercícios de "fixação". A professora, entretanto, se colocava à frente da organização de seu trabalho pedagógico, elaborava suas atividades educativas, destacava-se no contexto dominante que havia na instituição educativa onde atuava.

Entendemos que essa autoria de Júlia era aceita, em certa medida, pelos demais profissionais. Após produzir suas atividades, a professora solicitava para algum integrante da equipe de direção as cópias necessárias para sua turma, situação que aponta tanto para a presença de um planejamento prévio acerca do trabalho pedagógico, a organização e sistematização das ações educativas a serem empreendidas pela professora, como para o apoio que a direção da instituição educativa oferecia à docente. Em entrevista, a professora afirmou que, dentro das possibilidades, os demais profissionais providenciavam os materiais e recursos que ela solicitava para produção de suas atividades educativa, como foi a aquisição pela instituição educativa de um aparelho de data show.

Por outro lado, acompanhamos um momento em que essa mesma equipe de direção solicitou aos professores, em especial para Júlia, que não utilizassem esse aparelho de data show em sala de aula, pois o deslocamento constante poderia causar danos e os custos para o 
conserto seriam elevados. Esse era um dos recursos tecnológicos mais utilizados por ela, era por meio desse equipamento que a docente projetava os vídeos selecionados.

Nessa situação, interpretamos que, embora os profissionais da instituição oferecessem certo apoio ao trabalho pedagógico de Júlia, os custos econômicos possuíam um peso mais significativo do que a ampliação das possibilidades de aprendizagem. Além disso, consideramos que, as diferenças entre as práticas educativas que a professora oferecia aos seus alunos e o trabalho pedagógico dos demais professores, "incomodavam" os outros profissionais.

Durante a reunião em que houve essa solicitação, Júlia demonstrou forte indignação e argumentou sobre a importância do uso desse aparelho de data show na sua dinâmica educativa. A não aceitação de seus argumentos, deixou a professora nitidamente desanimada. Ainda assim, ela foi sujeito em sua atuação docente, fez uso do equipamento na sala de informática, uma sala pequena e pouco arejada, mas local permitido pela direção. E, com isso, manteve as atividades educativas que constituíam sua metodologia própria de ensino.

Ao longo da pesquisa, presenciamos, ainda, a diversificação de recursos pedagógicos e a seleção de diferentes materiais pela professora, que utilizou jogos matemáticos educativos produzidos por ela a partir do curso de pró-letramento; jogos que envolviam a alfabetização, que foram disponibilizados por programas do governo federal; vídeos educativos que pesquisava para expor e abordar certos conteúdos; apresentações artísticas (musicais e danças típicas); livros com imagens de obras artísticas; materiais diversos, como palitos de picolé para auxiliar as operações matemáticas, tinta guache para pinturas, dentre outros.

Interpretamos que essa elaboração de atividades educativas diferenciadas, a seleção desses recursos e materiais era possível porque havia processos subjetivos vinculados ao forte compromisso profissional de Júlia, que se empenhava na produção e seleção de meios pedagógicos que favorecessem a aprendizagem de seus alunos. Ao mesmo tempo, consideramos que os processos simbólicos e emocionais que se constituíam nessas ações de planejamento e realização de atividades produzidas por ela repercutiam na sua satisfação profissional, sua implicação para o trabalho pedagógico criativo. Nesses processos, colaboravam os indicativos de aprendizagem por parte de seus alunos, os resultados, como ela se referia.

As peculiaridades dessas atividades apresentavam-se, também, em relação às tarefas que os outros estudantes da instituição educativa desenvolviam. Naquele contexto educativo Júlia diferenciava-se, claramente, das práticas educativas realizadas pela maioria do grupo de 
profissionais. Percebia-se a movimentação de seus alunos, o entusiasmo que demonstravam em participar e realizar as atividades propostas por ela, o nítido interesse que tinham em responder e se colocar nas situações de diálogo. Nas outras turmas, observamos os alunos sentados, mais passivos, calados, respondendo ao livro didático, algumas atividades expostas seguiam um mesmo padrão desenvolvido por todos.

A professora reconhecia a diversificação de recursos e materiais, e as diferenças que causavam em seu trabalho pedagógico. Comentou, em certo momento, a respeito do que falavam outros professores: "A Rita (professora do segundo ano) fala que as minhas turmas são muito difíceis de trabalhar depois (risos). Eles chegam elétricos, até acalmar o ânimo e entrar no outro ritmo, ela teve muita dificuldade." (Júlia, Túnel do tempo, inclusão da autora). Compreendemos, no curso da pesquisa, que a professora percebia as implicações de sua proposta de ensino, era mais ativa, integrava um conjunto de recursos e materiais, em suas aulas, suscitava a participação dos estudantes, sua agitação. Esses aspectos repercutiam em diferenciações com o trabalho pedagógico desenvolvidos por outros profissionais.

A percepção dessas diferenças, entretanto, impactava subjetivamente a professora, favorecendo a constituição de produções subjetivas relacionadas à solidão que sentia diante daquele grupo de professores, à falta de parcerias para as atividades desenvolvidas. Em entrevista, afirmou que se sentia "ilhada": “[...] acaba que é ruim. Todo mundo compactua de um pensamento e você parece que está sempre na contramão do pensamento. Você é diferente. Angustia o grupo e você.” (Júlia, Entrevista II).

Consideramos que essa solidão articulava-se, também, às expectativas de Júlia quanto ao comportamento esperado de seus alunos. Nos momentos de jogos, ao longo das atividades realizadas, era solicitado, em diversos momentos, que os estudantes falassem mais baixo, que a ouvissem e se concentrassem nas tarefas. A professora demonstrou, em algumas situações, certa apreensão e angústia com o nível de agitação dos estudantes.

Ao ser questionada a esse respeito, afirmou: "não é a agitação que me incomoda, é a gritaria. Eu já falei isso pra eles, eu falo muito isso pra eles [...]. Me angustia porque é como se me desse a ideia de falta de controle [...]" (Júlia, Entrevista III). Entendemos que essa "falta de controle" que Júlia se referiu poderia ser apontada pelo grupo de professores, do qual ela percebia as diferenças quanto à sua proposta de ensino. O receio quanto às colocações, aos comentários dos outros profissionais, interferia na dinâmica educativa da professora, favorecendo as solicitações para que os alunos não fizessem muito barulho. 
Quando a pesquisadora perguntou como deveria ser o comportamento dos estudantes em sala de aula, ela afirmou: “o entusiasmo é uma coisa, mas a gritaria, as brigas, e começam as brigas [...] Eu gosto que eles tenham tempo de conversar, que eles tenham a capacidade de se concentrar. Tem criança que consegue isso tranquilamente" (Júlia, Entrevista III). Júlia tinha uma expectativa em relação ao comportamento dos estudantes, que se concentrassem ao longo de todas as atividades desenvolvidas, o que não ocorria pela própria especificidade das atividades que ela oferecia.

No processo construtivo-interpretativo, consideramos que os alunos tinham, de fato, um papel ativo na realização das atividades educativas propostas por Júlia, pois eram solicitados a se colocarem, falarem sua opinião, exporem suas ideias, suas hipóteses quanto aos conteúdos trabalhos, movimentarem-se nos jogos, danças e brincadeiras. Essa especificidade das atividades educativas propostas por Júlia, nos permitiu construir nossa interpretação acerca da forma como subjetivava o aluno: ser social que participava ativamente do processo de aprendizagem.

Para favorecer essa participação ativa dos estudantes, Júlia produzia diferentes situações educativas, o que nos possibilitou compreender o uso da imaginação como estratégia pedagógica privilegiada para abordar os assuntos em pauta e realizar as explicações. A professora criava pequenas histórias e personagens, que favoreciam a aproximação entre os conteúdos estudados e a realidade, o contexto dos alunos.

Para trabalhar os conceitos de dezena e unidade, por exemplo, Júlia criou uma situação em que havia a casa do senhor Dezena e do senhor Unidade. Na primeira casa, havia quartos grandes, com dez camas cada um deles, sendo que, para hospedar-se lá, o quarto precisava ficar completo, as dez camas ocupadas. Isso diminua os gastos da hospedagem e a organização do gerente (falas da professora durante as aulas). Na casa do senhor Unidade tinha apenas um quarto com nove camas. Por ser menor, algumas camas poderiam ficar vazias, sem influenciar no custo da hospedagem.

$\mathrm{Na}$ atividade cotidiana de contagem do número de alunos presentes, a professora relacionava essas casas à organização dos estudantes em situações de viagem, que estavam cansados e precisavam dormir, descansar. A partir dessas situações imaginadas, Júlia trabalhava os conceitos de dezena e unidade. Utilizava, para tanto, a participação dos alunos, que eram escolhidos para fazer a contagem oral de meninos e meninas, a simular as formas de organização naqueles quartos, fazer pequenas operações matemáticas e registrar no quadro branco algumas dessas questões. Em certas ocasiões, usaram palitos de picolé em uma 
correspondência um a um, agrupando o conjunto de hóspedes nas casas do senhor Dezena e senhor Unidade.

Em muitas e variadas situações educativas, observamos Júlia criar histórias, fantasiar acontecimentos para realizar as explicações acerca dos conteúdos em pauta. Além da situação citada, podemos apontar outras, como: o ciúme entre letras do alfabeto que queriam outras perto de si (como: qu, gu); a mudança de som quando letras estavam juntas ("a letra 'c' futuca o ' $h$ ' e mudam de som"); a viagem por países distantes, para onde tinham de ir de avião, em que era preciso apertar os cintos de segurança para o deslocamento; e outras situações, como para acalmá-los após um período de agitação, imaginar que estavam deitados em suas camas recebendo carinho.

Interpretamos que essas situações imaginativas criadas por Júlia tinham por finalidade facilitar o processo de aprendizagem dos alunos, constituindo-se a partir do seu intuito de colaborar para a construção do conhecimento por parte dos estudantes. Isso porque, para ela, a aprendizagem foi subjetivada, certamente, como essa apropriação e compreensão dos conteúdos e dos conhecimentos historicamente construídos pela humanidade. Para isso, ela se mobilizava, elaborava histórias, acontecimentos, em uma ação intencional de facilitar a compreensão dos conteúdos em pauta. Ao ser questionada acerca dessas situações criadas em seu trabalho pedagógico, afirmou que não as planejava previamente, construía durante as aulas, a partir das necessidades que percebia e do que julgava poder ajudar a compreensão dos assuntos em pauta.

Consideramos que, embora não planejasse as situações imaginativas, estas se constituíam como uma estratégia pedagógica relevante em sua dinâmica educativa, que a professora utilizava em seu trabalho pedagógico para favorecer a aprendizagem e desenvolvimento de seus alunos. No processo criativo de elaborar essas situações, a imaginação se constituía como uma ferramenta para transcender o momento vivido, favorecendo a ampliação das experiências vivenciadas pelos estudantes e, assim, a aprendizagem dos conteúdos abordados.

Essa afirmação se relaciona às colocações de Mitjáns Martínez (2014, p. 78) a respeito da imaginação na aprendizagem criativa, que: “[...] constitui importante ferramenta no processo de ensino-aprendizagem, no sentido de que permite ao aprendiz representar situações não vividas, inclusive muito distantes de sua experiência pessoal.”. Observamos esse aspecto no trabalho pedagógico de Júlia, que lançava mão da imaginação como uma estratégia pedagógica, um meio de ampliar as oportunidades de aprendizagem dos estudantes. 
Para a professora, ela era muito imaginativa e isso incluía diferentes campos de sua vida: “[...] meu marido fala, o caminho é daqui até ali, e eu vou pelo caminho mais longo, pela possibilidade mais remota, mais... é o que mais me move. Dificilmente eu vou por uma trilha objetiva. [...]" (Júlia, Entrevista I). Interpretamos, no decorrer do estudo, que essa imaginação, a que a professora se referia, era, de fato, situações, alternativas de ação que a própria Júlia criava, as quais geravam maior disponibilidade, maior empenho em sua consecução.

Em entrevista, comentou, também, que em sua infância brincou muito sozinha, criava muitas histórias, personagens, situações, ficava horas brincando assim. Não brincava muito na rua, pois na época morava em prédio e o seu pai tinha muito medo de violência. Quando viajava para o interior, onde moravam outros familiares, brincava com os seus primos (Júlia, Entrevista I). Hipotetizamos que essas brincadeiras que realizava sozinha possam tê-la auxiliado nesse processo de criar suas próprias "histórias educativas", imaginar situações diversas, oportunizando-lhe, no cotidiano escolar, a utilização de sua imaginação como uma estratégia pedagógica criativa. Esses momentos em que brincava sozinha podem ter lhe gerado um repertório imaginativo e vias alternativas para explicações e relações entre diferentes conteúdos, o que Júlia agregava ao seu trabalho pedagógico, criando novidades com valor para o processo de aprendizagem e desenvolvimento dos alunos.

Além disso, a professora comentou que tinha muitas dificuldades nas matérias exatas. Por vezes, ficou em recuperação nas disciplinas de matemática e física. Mas, gostava muito de literatura; nas disciplinas humanas, tinha mais facilidade em aprender. Afirmou: "Tudo que fosse mais fantasioso, eu ia embora." (Júlia, Entrevista I). Ela continuou o relato explicando que: "Pra estudar, eu lembro que, quando eu era maior, eu tinha que dar aula pra mim mesma, pra conseguir reter. Então, eu dificilmente lia e retinha. Eu tinha que dar aula pra mim mesma, explicar, aí eu retinha aquela informação" (Júlia, Entrevista I). Na pesquisa, essas informações nos conduziram a compreensão de que a imaginação pode ter sido uma estratégia pedagógica utilizada por ela mesma para facilitar sua aprendizagem, um recurso subjetivo para a própria Júlia. Ela reconhecia suas dificuldades e se mobilizava para criar situações, como de ensino para si mesma, que facilitassem a compreensão dos conteúdos em pauta.

Essa situação nos possibilitou entender as colocações de Mitjáns Martínez (2014) acerca do papel da imaginação como elemento constitutivo dos processos de compreensão. Para a autora, a imaginação pode se constituir como um recurso subjetivo que participa da aprendizagem criativa, se relaciona a processos intencionais de compreensão de conteúdos 
escolares desafiadores para o aprendiz. Aspecto esse que, no caso de Júlia, nos permitiu hipotetizar sua criatividade na aprendizagem, ela foi capaz de produzir novidades com valor para sua própria compreensão dos conteúdos estudados. Tema que, devido às peculiaridades do estudo proposto, não iremos aprofundar no momento.

Além de criativa, consideramos que aquela situação de imaginar as explicações para si mesma foi uma expressão de seu papel ativo na vida, de um modo geral. De fato, ao longo da pesquisa, Júlia demonstrou essa possibilidade de gerar alternativas próprias diante das mais diversas situações que se constituíam em seu cotidiano, seja no campo profissional ou pessoal. O seu protagonismo no trabalho pedagógico e sua autoria na elaboração de suas práticas e recursos de ensino são indicativos dessa criatividade da professora, de sua autonomia e singularidade diante do enfretamento de exigências diversas que surgiam em sua profissão.

Júlia não almejou a docência, o seu encontro com a profissão ocorreu a partir de uma conjuntura de exigências. Para sua família, era fundamental que ela ingressasse em uma instituição de ensino superior pública e, como registrado antes, tinha dificuldades em disciplinas exatas. Ela, então, diante da exigência que percebia acerca de sua aprovação no vestibular, escolheu um curso da área de humanas em que houvesse a maior possibilidade de aprovação. Relatou:

Quando eu fui fazer o vestibular, eu tinha muito claro na minha cabeça que tinha que
ser uma pública, eu não tive a escolha natural de fazer aquilo que, em tese, eu
gostasse. Eu tinha que fazer alguma coisa porque eu tinha que entrar no ensino
superior. Eu tinha muita dificuldade em exatas, física, matemática. Sempre tive. Eu
sempre fui muito, muito bem em humanas, mas as exatas sempre foram o meu
calcanhar. Então, quando eu fui pegar a lista de cursos... Eu lembro que até fiz
publicidade na Católica, passei em publicidade, em comunicação. Eu achava que era
a minha cara! Mas, quando eu fui pegar da pública, que eu vi a concorrência, eu fiz
Pedagogia, que dentro da área de humanas, era a única coisa que eu via como plano
B e possível aprovação. Eu lembro que eu olhava a estatística de candidatos por
vaga, e falei: é esse que eu vou fazer. Aí, eu passei na estadual e na federal. Aí,
comecei a cursar, acabei gostando, depois que eu entrei. (Júlia, Entrevista I, grifo
nosso).

Durante o curso, Júlia se aproximou da educação e da possibilidade de ser professora. $\mathrm{Na}$ atuação docente, percebeu-se na necessidade de criar meios, práticas educativas que viabilizassem a aprendizagem de seus alunos, de realizar com êxito a função social da educação, conforme subjetivada por ela, de atuar segundo seu compromisso profissional. A criatividade no trabalho pedagógico, com isso, foi se constituindo, ao longo de sua experiência docente, como a rota alternativa criada por Júlia para alcançar os seus propósitos educativos, uma forma de atuar que lhe proporcionava satisfação pessoal e 
profissional, a segurança de que agiu de acordo com seus valores e crenças, mesmo sem ser a profissão "escolhida" por ela.

Compreendemos que a construção dessa rota alternativa foi possível porque havia em Júlia um funcionamento psicológico criativo, esse movimento de gerar alternativas diante dos enfrentamentos vividos. A criatividade, assim, se mostrou em uma via mais ampla, aliando-se ao que Mitjáns Martínez (2009a, p. 34) afirma acerca da dimensão funcional da criatividade. Para a autora, a "[...] criatividade nas suas diversas formas de manifestação não seria um processo a mais, mas formas específicas de expressão da subjetividade em diversos momentos e contextos [...]”, caracterizando-se pela “[...] assunção, em diferentes níveis, de alternativas autônomas e singulares de ação no enfrentamento de situações pessoalmente significativas." (MITJÁNS MARTÍNEZ, 2009a, p. 35).

No caso dessa professora, consideramos que indicadores a respeito dessa dimensão funcional da criatividade relacionam-se à expressão criativa que demonstrou em seus processos de aprendizagem, como citado antes; ao seu envolvimento com diferentes atividades para além do campo profissional (as aulas na academia, grupos de danças, curso de inglês); à sua vontade de conhecer o "novo", "diferente", o que se vinculava ao seu interesse por viagens e por conhecer outros lugares; e à constituição da criatividade no trabalho pedagógico como rota alternativa frente às necessidades advindas de sua atuação docente.

Nessa perspectiva, interpretamos que, no caso de Júlia, sua criatividade no trabalho pedagógico decorria de um funcionamento psicológico criativo, por essa possibilidade de gerar alternativas próprias e singulares diante das adversidades e das situações inusitadas que se formavam em sua vida e na sua profissão. A própria constituição de sua criatividade no trabalho pedagógico pode ser considerada como decorrente dessa mobilização de Júlia para gerar alternativas diante do vivido: uma profissão que sentia necessidade de se adaptar, de realizar com êxito.

Interpretamos que essa forma de funcionamento repercutia em sua atuação profissional e lhe possibilitava uma abertura ao novo, uma flexibilidade em organizar-se diante da experiência vivida, favorecendo a expressão criativa da professora em seu trabalho pedagógico, a geração de novidades com valor para a aprendizagem e desenvolvimento de seus estudantes.

Por outro lado, a criatividade no trabalho pedagógico gerava a constituição de processos simbólicos e emocionais que atualizavam as configurações subjetivas que participam de sua expressão criativa. Na elaboração e realização de suas atividades constituíam-se sentidos 
subjetivos associados à satisfação com o trabalho desenvolvido, à crença de que realizava com êxito sua função, em especial, quando percebia os avanços na aprendizagem dos alunos. Produções subjetivas que atualizavam os núcleos subjetivos relacionados ao trabalho pedagógico criativo.

Essa satisfação se articulava a outros processos subjetivos que permitiam a caracterização da professora como uma pessoa alegre, bem humorada e com nítido vigor. Durante a pesquisa, Júlia mostrou-se feliz, bastante sorridente, entusiasmada com a vida, o que entendemos a partir de seu sorriso, sua energia em realizar os compromissos assumidos por ela.

A aproximação à subjetividade individual da professora permitiu outras construções que viabilizam a compreensão de seu funcionamento psicológico criativo.

\subsubsection{A subjetividade individual da professora Júlia: sua condição de sujeito e os núcleos subjetivos que participavam de sua criatividade no trabalho pedagógico}

No processo construtivo-interpretativo acerca da expressão criativa da professora Júlia, consideramos que sua intencionalidade pedagógica, sua autoria e o seu protagonismo no trabalho pedagógico se constituíram como expressão singular de sua atuação como sujeito em sua atuação profissional. Essa autoria se relacionava à elaboração de uma metodologia de ensino, às atividades educativas que produzia, aos recursos e materiais que ela selecionava ou construía, e o uso da imaginação como estratégia pedagógica. O protagonismo de Júlia, nessa perspectiva, vinculava-se a sua iniciativa própria e autonomia na organização do trabalho pedagógico. Essas construções sobre a condição de sujeito coadunam com a afirmação de González Rey (2011a), quando o autor afirma que a pessoa se torna sujeito quando desenvolve alternativas próprias em suas diversas práticas, mantendo a produção de sentidos subjetivos associada a tais caminhos.

Ao tratar a respeito do sentido de ser professora, Júlia registrou: "A docência promove em mim um encantamento e enquanto eu acreditar, sinto-me motivada a mobilizar recursos e estratégias para intervir junto aos meus alunos.” (Júlia, Redação II). Interpretamos, na pesquisa, que sua autoria e o seu protagonismo possibilitavam a constituição de sentidos subjetivos relacionados à satisfação profissional e pessoal, mantendo-a ativa na produção de novidades com valor para o processo de aprendizagem e desenvolvimento dos alunos, participando de sua atuação docente e de seu direcionamento à superação profissional. Essas 
produções subjetivas repercutiam e tinham valor na organização subjetiva da própria professora, para o núcleo subjetivo relacionado ao trabalho pedagógico.

Havia, assim, o que afirma González Rey (2011a), a unidade inseparável dos sentidos subjetivos e a subjetividade individual, implicando, simultaneamente, a processualidade da ação, das relações e da produção de sentidos subjetivos, remetendo à compreensão de atividades e práticas humanas subjetivadas. Para ele (GONZÁLEZ REY, 2011a, p. 214, tradução nossa): "Essa inseparabilidade, essa tensão permanente entre a organização subjetiva de uma pessoa e sua produção subjetiva em diversas ações, é uma condição essencial na definição da categoria de sujeito [...].”.

Júlia, ao escrever acerca do sentido de sua vida, afirmou:

O sentido da minha vida hoje é sempre atuar da maneira mais transformadora possível, seja no relacionamento com a minha família e esposo, como na sala de aula. Sempre quero mais dos meus alunos. Sinceramente, oportunizá-los acesso a um mundo de opções e escolhas.

Este ano iniciei com a pretensão de repetir o planejamento do ano passado, mas foi completamente diferente. $\mathrm{O}$ sentido da minha vida hoje é marcar significativamente a todos que me cercam, fazê-los se superarem, protagonizarem suas escolhas. (Júlia, Redação I).

Nesse trecho, Júlia explicitou o seu intuito de oportunizar aos seus alunos o acesso aos conhecimentos e, com isso, a superação de possíveis dificuldades, oferecer condições de mudanças da situação social que viviam. Consideramos que esse desejo que mobilizava a professora decorria de produções subjetivas vinculadas à sua família, ao compromisso social e ao trabalho pedagógico como núcleos subjetivos, que ressaltaremos a seguir.

Aliados a essas produções, incluímos os sentidos subjetivos decorrentes do próprio processo de elaborar e realizar suas atividades pedagógicas, que em conjunto com as demais produções subjetivas, possibilitaram a constituição de uma rota, uma via alternativa para o "encontro" de Júlia com a docência: a criatividade no trabalho pedagógico. De modo que ser professora foi consequência de sentir-se professora e de atuar com vistas à ampliação da aprendizagem de seus alunos.

Essa construção vincula-se à compreensão dos principais núcleos subjetivos que participavam da criatividade de Júlia no trabalho pedagógico. 
4.2.5.1 Os principais núcleos subjetivos da professora Júlia que participavam de sua criatividade no trabalho pedagógico

No curso da pesquisa, compreendemos que entre os núcleos subjetivos que integravam a subjetividade individual da professora Júlia, participavam de sua criatividade no trabalho pedagógico aqueles vinculados: à família, ao compromisso profissional e ao trabalho pedagógico, o que trataremos a seguir.

\section{A família como um núcleo subjetivo}

No processo construtivo-interpretativo, entendemos que a relação entre os pais e Júlia constitui um núcleo subjetivo relevante na subjetividade individual da professora. Os sentidos subjetivos que emergiram dessa relação participavam na sua atuação profissional, bem como de sua criatividade no trabalho pedagógico. O próprio encontro com a educação foi permeado por produções simbólicas e emocionais que se constituíram nessa relação.

O projeto do seu pai quanto à aprovação no vestibular tornou-se seu, Júlia se apropriou dele e se mobilizou para concretizá-lo; isso pode ser percebido tanto na aprovação no vestibular, como na aprovação em um concurso público, posteriormente. Ela foi capaz de gerar alternativas que permitissem o seu envolvimento, compromisso e esforço para alcançar os planos de sua família. Associamos essa situação, também, ao seu funcionamento psicológico criativo.

Para Júlia, era preciso ingressar na universidade pública, os pais solicitavam isso:

Tinha que passar! Meu pai... Era algo da vida dele! A frustração dele é que ele saiu do interior, que era filho prodígio da família. Meu pai dava aula, meu pai era muito... Tanto que em matemática, era ele até que ensinava meu irmão. Botava a mesa na luz da sala, virava a madrugada comigo, sempre. Só que ele saiu do interior com uma promessa, como o filho que ia fazer faculdade, só que ele não conseguiu passar. Ele morava em uma pensão, aí ele falava que não tinha a menor condição, tinha que trabalhar, estudar, aquela loucura toda e ele não conseguiu passar. Então isso era uma coisa que ele tinha dentro dele muito forte. Tanto que eu já era adolescente, presenciei uma discussão dele com o meu tio sobre isso. [...] Ele tinha como premissa na vida dele que os filhos tinham que estudar. (Júlia, Entrevista I, grifo nosso).

Esse relato exemplifica a importância da aprovação no vestibular na história de vida dessa família. Relevância que lhe gerava, certamente, sentidos subjetivos vinculados ao compromisso com seus estudos, ao desejo de concretizar os projetos de seu pai e realizar os caminhos traçados por ele. Júlia afirmou: "Eu via o esforço do meu pai. Ele ganhava, 
naquela época, um salário mínimo. A gente sentia o esforço dos dois. A gente cresceu com isso." (Júlia, Entrevista I).

Com base na pesquisa, compreendemos como essas produções subjetivas mobilizavam Júlia, favorecendo-a a buscar meios para satisfazer as expectativas paternas, seja em relação aos estudos e aprovação no vestibular, seja como profissional. Essas produções tornavam-se ainda mais significativas diante do diagnóstico de que o seu pai perderia a visão gradativamente, quadro clínico que foi se agravando como passar do tempo. Com choro e forte emoção, Júlia afirmou: "Eu sempre, a vida inteira, eu tive essa superação. A gente tinha essa noção de realidade muito forte. Então, a gente não tinha sonhos normais, tinha que entrar na faculdade." (Júlia, Entrevista I).

Passar no vestibular, portanto, era para Júlia um forte compromisso, com a família e consigo mesma. A aprovação foi, com isso, um momento de grande satisfação e de realização pessoal; era a concretização de um projeto que ela tomou para si. Interpretamos, nessa perspectiva, que havia sentidos subjetivos em Júlia vinculados à sua satisfação em atender aos propósitos de sua família, em especial, ao de seu pai. E mais, era uma busca por possibilitar a felicidade deles, que se relacionava a realização do que eles tinham como expectativas de vida, projeção para o futuro. Ao completar frases, Júlia registrou:

\footnotetext{
13. Estou melhor quando sinto um resultado esperado

17. Desejo mais tempo de qualidade com minha família

23. Amo minha família

30. A felicidade está em momentos de alegrias, paz com os que amo

34. Meu maior desejo a felicidade da minha família

37. Minhas ambições são não penso a respeito

40. Farei o possível para alcançar a tranquilidade dos meus pais

53. O lar aconchego, paz, tranquilidade

57. Uma mãe doação, amor, sacrifício

67. Meu maior temor pensar em perder algo que ame
}

Nessas frases, consideramos a importância dos pais de Júlia para sua satisfação pessoal; para ela, era importante atender suas expectativas, concretizar os seus planos. Esta situação gerava processos subjetivos associados a sua implicação para a realização de projetos que não eram de sua autoria, projetos que ela não idealizou para sua vida nem para sua atuação profissional.

Entendemos que essas produções subjetivas favoreceram a constituição de limitações, por parte Júlia, quanto a suas projeções para o futuro. Ela ficou limitada, restrita a seguir as projeções de seu pai e acabou não desenvolvendo a possibilidade de traçar planos, projetar o seu futuro por si mesma, de acordo com seus interesses e aspirações. As questões de pesquisa vinculadas ao futuro, seja no campo profissional, seja no pessoal, ficaram sem respostas 
concretas. Colocou, em entrevista, que não pensava no futuro, estava numa zona de conforto, que os seus planos eram mais para o campo pessoal, mas, ainda assim, não os indicou de forma clara. Na profisssão, afirmou: “estou parando para pensar agora.”. Ao completar frases, Júlia registrou:

11. Meu futuro é incerto, não penso muito

39. Minha vida futura não sei

62. No futuro não penso

Compreendemos que essa ausência de projeção futura estava relacionada à forte presença do pai na determinação das metas de vida para a professora. O pai foi para Júlia uma figura de grande impacto subjetivo; a relação com ele, com sua deficiência visual, e sua força de vontade e empenho em favorecer a formação dos filhos tiveram, para ela, um peso significativo em sua organização subjetiva. Em entrevista, comentou:

[...] É claro que quando ele perdeu (visão), foi muito mais 'punk' pra gente. Mas ele era um cara que contava piada. Tudo que ele podia, fazia sozinho. Não gostava de ajuda, queria fazer. Então, a gente meio que não sentia. (Júlia, Entrevista I, inclusão e grifo da autora).

Essa forte influência do pai repercutiu, certamente, para a constituição de sentidos subjetivos vinculados a necessidade de aprovação da figura paterna, do reconhecimento social por parte dele do que Júlia fazia ou realizava. Essas produções subjetivas podem estar relacionadas ao reconhecimento do pai acerca de sua profissão, à sua valorização da profissão docente. Ao completar frases ela registrou, também:

\section{Meu maior medo perder quem eu amo 63. Necessito ser reconhecida, amada, me superar 65. Odeio nada, pensar em perder algo que ame 74. A felicidade receber afeto e estar tranquila}

Essa necessidade de aprovação relacionava-se a vários campos da vida de Júlia, no que incluímos tanto a profissão, como o seu casamento. Ao falar sobre sua adolescência, relatou que foi muito "pacata", não teve muitos passeios ou viagens. O pai tinha bastante medo, não a deixava sair sozinha. Foi pegar ônibus sozinha quando cursava a graduação. Conheceu o seu esposo na instituição educativa em que fez a educação básica, namoraram durante todo esse período. Para ela, o casamento foi a culminância de muito tempo de relacionamento.

Esse relacionamento com o marido oportunizou certa liberdade em relação à vida e a própria mudança de Estado, a saída de sua região natal, e, possivelmente, viabilizou produções subjetivas diversas. Dentre essas produções, interpretamos que estavam os sentidos subjetivos vinculados à liberdade de escolha, à possibilidade de viver outras experiências mais amplas que o universo proporcionado por seus pais. No trabalho 
pedagógico, tais produções subjetivas podem se relacionar à sua ousadia em elaborar sua própria metodologia de ensino, em subverter os métodos tradicionais de alfabetização, implicando sua criatividade no trabalho pedagógico.

Ao comentar acerca do significado do casamento para sua vida, afirmou:

O casamento foi uma libertação, foi quando eu consegui realizar muito dos meus sonhos, consegui minha independência, as viagens que a gente faz. É uma parte da minha vida assim... Como se eu pudesse tudo. [...] Foi a liberdade desse núcleo familiar que tinha uma vida muito restrita. (Júlia, Entrevista I).

Consideramos que os sonhos a que Júlia se referiu dizem respeito aos passeios que o casal realizou, viagens pelo Brasil e exterior, e ao fato de poder fazer aulas de dança, frequentar academia, fazer um curso de inglês. Atividades que ela desenvolve ao longo da semana e que pareceram fonte de grande satisfação, como observado nos momentos de diálogos informais com a pesquisadora e com outros colegas da instituição educativa onde atuava. Júlia comentava seus êxitos, seu avanço na aprendizagem do inglês, sua alegria em dançar e frequentar as aulas na academia.

O casamento se constitui, então, como uma oportunidade de Júlia ampliar suas experiências de vida, experimentar outras situações para além da obrigação referente aos estudos. Essas oportunidades fizeram com que o relacionamento com o esposo possuísse um papel significativo na sua organização subjetiva. A respeito dessa relação, ela afirmou, também: "ele é o meu oposto, o que eu tenho de imaginativa ele tem de racional, o que eu tenho de extrovertida, ele... Então, é como se ele me completasse, ele fosse o centro, ele fosse o que me move, o que me cutuca, que me tira desse mundo de fantasia. (risos)".

Nessas frases, interpretamos que havia diferenças entre eles e que isto lhe parecia agradável, dando-lhe um suporte para realização de diversas atividades que empreendia. Compreendemos que a situação de liberdade advinda do casamento, naquele momento, relacionava-se às possibilidades que o relacionamento lhe oportunizava, favorecendo a constituição de processos subjetivos relacionados ao apoio emocional que sentia e, condições financeiras estáveis. Produção subjetiva essa que se integrava aos sentidos subjetivos associados à liberdade e à ampliação de suas experiências de vida. No período da pesquisa, esse apoio emocional participava, certamente, de pensamentos referentes a mudanças na profissão, por parte de Júlia, o que abordaremos mais adiante.

Tais processos convergiam para a constituição da família como um núcleo subjetivo relevante na subjetividade individual da professora, repercutindo inclusive na sua criatividade no trabalho pedagógico e no forte compromisso profissional que ela demonstrou no curso da pesquisa. 


\section{Compromisso profissional como um núcleo subjetivo}

Compreendemos, no caso de Júlia, que os exemplos de superação vivenciados por seu pai, em decorrência da perda gradativa da visão, favoreceram a constituição de sentidos subjetivos que implicavam a ação, o movimento da professora para superar suas dificuldades. Em entrevista, ela destacou: “[...] Apesar de tudo, ele nunca se vitimizou, nunca vi o meu pai reclamar de nada. [...] Tudo que ele podia, fazia sozinho. Não gostava de ajuda, queria fazer. [...]" (Júlia, Entrevista I). Essa conduta era admirada pela professora e, interpretamos, ampliava-se para outros campos de sua vida.

Na profissão, consideramos que Júlia demonstrou esse intuito de superação, de fazer o que podia para favorecer a aprendizagem e desenvolvimento de seus alunos. Entendemos que essa perspectiva de superação gerava produções subjetivas que integravam o seu trabalho pedagógico e implicavam a expressão criativa da professora no trabalho pedagógico. Nesse processo, articulavam-se processos simbólicos e emocionais vinculados ao seu desejo de realizar com êxito suas práticas educativas, "fazer bem feito". Ao completar frases, Júlia registrou:

49. Esforço-me diariamente por desempenhar com maestria minhas funções

69. Deprimo-me quando me sinto impotente, mas é raro

58. Sinto alegria, esperança, decepção, vontade

Nesses registros, a professora expressou o desejo de desempenhar suas funções com maestria, o que relacionamos à possibilidade de sentir-se impotente, quando julgasse não ter favorecido a aprendizagem de seus alunos. Hipotetizamos que a maestria pode ser para Júlia um meio para alcançar os seus objetivos de aprendizagem e aproximar-se da forma como a função social da educação foi subjetivada por ela. Ao escrever a respeito do sentido de ser professora, registrou:

Ser professora hoje para mim é promover transformações que possibilitem aos meus alunos fugirem do determinismo social. Possibilitar ferramentas para que eles possam construir suas pontes. Possibilitando este encantamento pelo hábito de aprender, acredito que eles consigam de alguma maneira contornar as dificuldades sócio-familiares, mesmo sabendo que ao apoio destes protagonistas é fundamental para o pleno desenvolvimento do educando. (Júlia, Redação II).

Como abordado antes, interpretamos que, para a professora, sua atuação docente tinha como propósito promover possibilidades de mudanças na situação social vivida por seus estudantes e, até mesmo, de ascensão social e econômica, já que muitos deles tinham poucas condições financeiras. Por isso, Júlia empenhava-se para incluir em seu trabalho pedagógico 
assuntos que se relacionavam ao conhecimento de mundo, incluindo o acesso aos bens culturais diversos.

Essa intencionalidade pedagógica era possível porque existia na professora sentidos subjetivos relacionados ao desejo de colaborar para mudanças nas condições socioeconômicas de seus alunos, o que se vinculava ao forte compromisso profissional de Júlia e sua própria história de vida. Como relatado por ela, seu núcleo familiar de origem possuía poucos recursos financeiros, contou que, durante a educação básica, não pôde frequentar cursos de língua estrangeira, por exemplo. E ela, a partir de sua escolaridade, da sua formação universitária, teve outras oportunidades de emprego, que lhe geravam condições de viver, na atualidade, situações diversas, como o curso de inglês que frequentava, aulas de danças, dentre outras atividades.

Tais produções subjetivas, vinculadas ao desejo de colaborar para mudanças nas condições socioeconômicas de seus alunos e realizar com êxito suas práticas educativas, mobilizavam a professora para a realização de um trabalho pedagógico criativo, tornando-a exigente consigo, com os seus alunos e outros integrantes da dinâmica educativa. Em entrevista, Júlia afirmou:

Eu sempre fico nessa busca, de não ficar nenhum a menos [...]. A gente tem essa obrigação de que todas as crianças saiam com padrão mínimo de aprendizagem [...]. Eu não vou sossegar se eu não introduzir tudo que tenho que apresentar [...]. É minha obrigação, eu tenho um currículo para cumprir. (Júlia, Entrevista II).

Essa forte exigência de Júlia com o seu trabalho pedagógico gerava-lhe sentidos subjetivos relacionados à obrigação que sentia quanto ao alcance dos resultados almejados por ela. Essas produções subjetivas convergiam para o seu compromisso profissional, bem como para a criatividade no trabalho pedagógico. "[...] Motiva a ideia de que eu fiz uma sequência didática fantástica. Isso me deixa motivada, me frustra a noção de que eu não fiz o meu melhor, isso me frustra muito. Eu me cobro muito [...]” (Júlia, Entrevista II). Para ela, não alcançar os objetivos que determinou para si mesma, causava-lhe frustração, era a incompetência a que se referiu antes.

Júlia buscava, então, promover situações pedagógicas que favorecessem a aprendizagem de seus alunos, movimentando-se para que todos eles avançassem na construção de conhecimentos. Empenhava-se, com isso, para a produção de novidades com valor para os processos de aprendizagem e desenvolvimento de cada um deles. Para tanto, reconhecia, também, a importância da colaboração dos demais integrantes: os estudantes, as famílias e outros profissionais da instituição, e ficava na expectativa dessa participação. Havia 
certa exigência da professora para que as famílias auxiliassem, acompanhassem o processo de aprendizagem de seus filhos.

Hoje minha frustração é essa. Fazer tanto, avançar tanto e saber que eles não estão alcançando o seu máximo porque as famílias não chegam junto. Se as famílias chegassem esses meninos estavam... [...] Isso gera uma frustração. Você dá o seu melhor todo dia, pras famílias darem o mínimo, pra sociedade dá o mínimo, pro governo dá o mínimo. E a criança, coitada! Isso me frustra. Como também me emociona aquela criança que vence tudo, e vai. Criança que nunca traz o dever de casa e está produzindo textos lindos. As famílias nem acreditam quando eu mostro. Os pais ficam chocados. (Júlia, Entrevista II).

A expectativa de Júlia quanto à participação das famílias tornou-se certa cobrança. Durante entrevista afirmou, ainda: "Tem criança que dorme onze e meia, acorda dez da manhã, não senta em uma mesa para comer, faz dever (atividade de casa) em qualquer lugar, responde a própria mãe. Então, assim... esse é o meu desafio [...]”. (Júlia, Entrevista III). Para ela, o abandono familiar era cada vez maior, faltava o apoio das famílias: “[...] a falta de apoio de outros protagonistas e de seu comprometimento tem levado a uma angústia de como reagirei caso perca a capacidade de acreditar.”. (Júlia, Redação II).

Essa angústia que ela registrou relacionava-se também às cobranças que fazia a respeito da participação dos demais profissionais da instituição educativa. Júlia, de certa forma, exigia que eles tivessem o mesmo empenho e esforço que ela tinha para favorecer a aprendizagem dos alunos. O embate com a situação presente na realidade educativa em que vivia e a percepção de que nem todos os professores se mobilizavam para isso geravam-lhe sentidos subjetivos associados à decepção com os docentes e com a educação. Com forte indignação afirmou que não concordava e não conseguia aceitar que os alunos chegassem ao terceiro ano do ensino fundamental e reprovassem:

Não é normal o menino chegar no terceiro ano sem conseguir ler e escrever. Não adianta me disser que é um ciclo, que não é normal! Alguma coisa está errada. O menino tem que sair da minha mão, no primeiro ano, com consciência fonológica pronta. Ele não vai sair como o outro, mas ele vai sair com a noção de letra, som e palavras. [...] O normal é você batalhar pra que isso ocorra agora. (Júlia, Entrevista I).

Interpretamos que, nessas colocações, Júlia demonstrou o seu compromisso profissional e como esperava que os demais profissionais se empenhassem da mesma forma para possibilitar o avanço na aprendizagem dos alunos. Ao completar frases, registrou também:

49. Esforço-me para me superar

50. As contradições me irritam muito

52. Penso que os demais não se esforçam tanto, me ensinam

54. Incomoda-se a apatia

Para a professora a realidade da educação no ensino público estava repleta de contradições, e isso lhe causava produções subjetivas vinculadas ao desânimo com a 
educação, descrença quanto à possibilidade de mudanças nos processos de ensino. Ela afirmou: "O que acontece. Eu não aceito a realidade como ela é, e vivo sempre acreditando que essa realidade pode ser superada. Quando, às vezes, eu não supero o tanto que eu poderia superar, isso me gera frustração.” (Júlia, Entrevista III).

Júlia percebia-se na contramão desse descompromisso profissional predominante na educação que julgava caracterizar os processos de ensino na Secretaria de Educação. Sentia-se solitária frente à apatia que os profissionais demonstram em sua atuação docente. Para ela:

[...] Eu não consigo aceitar a realidade, não tem jeito. Acho que esse é o meu maior problema na Secretaria, não consigo aceitar a realidade. [...] Isso me angustia muito, o faz de conta, eu brinco assim: o sorriso de Monalisa, aquele que tudo fala e nada diz [...] Essa coisa passiva, isso me mata! Acho que essa é minha maior frustração na Secretaria. (Júlia, Entrevista III).

Compreendemos que essas produções subjetivas organizavam-se como um núcleo subjetivo que constituía o forte compromisso profissional. Dele participavam tanto o seu desejo de superação, de realizar com êxito suas funções, de possibilitar mudanças na vida de seus alunos, como também processos subjetivos associados à obrigação quanto aos resultados almejados e a decepção com os docentes e com a educação. Sentidos subjetivos que repercutiam no trabalho pedagógico como um núcleo subjetivo.

\section{Trabalho pedagógico como um núcleo subjetivo}

As produções subjetivas que se configuraram em seu compromisso profissional participavam do trabalho pedagógico criativo desenvolvido por Júlia. O processo construtivointerpretativo que foi realizado durante a pesquisa, nos possibilitou a compreensão de que, do trabalho pedagógico, propriamente, poderiam participar outros sentidos subjetivos que repercutiam para sua expressão criativa e para a sua atuação docente.

Dentre os processos subjetivos que se configuraram no trabalho pedagógico da professora Júlia, estavam sentidos subjetivos relacionados à angústia e ao sofrimento que ela sentia em relação à sua atuação profissional. Ao completar frases, registrou:

17. Este lugar representou muito, hoje representa uma dúvida, angústia

18. Minha profissão é meu orgulho, mas minha maior decepção

20. Eu busco por equilíbrio, autoaceitação

22. O trabalho tem me deixado mais angustiada, contudo, continuo feliz

29. Esse ano letivo estou mais calma, certa- pequena desmotivação, mais consciente

41. Frequentemente, reflito sobre minha ansiedade.

46. Frequentemente, sinto realização e angústia no trabalho, prazer e tranquilidade (vida pessoal) 
Interpretamos que os processos subjetivos constituídos no espaço escolar podem ter se configurado como satisfação em ter alcançado uma profissão e ter cumprido as expectativas paternas em relação ao ingresso no ensino superior, constituindo-se como o orgulho a que ela se referiu. Entretanto, entendemos que existiam, ainda, outras produções subjetivas que se relacionavam à decepção com a realidade encontrada, seja em relação aos outros docentes, à participação das famílias, conforme abordado antes, ou com o comportamento esperado dos alunos.

No curso das observações, consideramos que havia uma tensão entre a expectativa da professora quanto ao comportamento dos alunos e a agitação gerada a partir de sua proposta de ensino. Suas atividades requeriam a participação dos estudantes, o seu movimento, sua fala. No entanto, os diálogos excessivos, os debates entre eles, o fato de se levantarem das carteiras, geravam, em alguns momentos, a insatisfação com o seu próprio trabalho pedagógico. Essas situações podem ter sido compreendidas por Júlia como indisciplina. Ao ser questionada sobre como percebia a indisciplina em sua sala de aula, Júlia afirmou:

\begin{abstract}
Eu acho que a indisciplina, acaba que eles... Eles não conseguem entender a dinâmica da vida. São pessoas que em todos os campos da vida vão ser prejudicadas, na sua vida profissional, na sua vida amorosa, na sua vida com os amigos. São pessoas que sempre vão estar sem dar conta da sua própria vida. Isso me angustia. Então, a indisciplina me desmotiva. (Júlia, Entrevista III).
\end{abstract}

Esse impasse entre as expectativas da professora a respeito do modo como os estudantes deveriam se comportar e a agitação deles, oportunizava a constituição de processos simbólicos e emocionais relacionados à angústia e à frustração que Júlia sentia em relação ao seu trabalho pedagógico (não obtinha o comportamento esperado de seus alunos), produções subjetivas que geravam dúvidas quanto à sua permanência na profissão.

Compreendemos que, essas produções subjetivas, integravam-se às reflexões acerca da profissão, não foi algo que ela projetou por si mesma, mas uma escolha gerada pelas circunstâncias vividas no contexto familiar e social do período de sua formação inicial. No momento, a autonomia financeira que possuía e a sensação de ter cumprido com as exigências de seu pai, aliada à liberdade que o casamento lhe conferiu, podem ter interferido para as reflexões de Júlia a respeito de sua atuação profissional. Isso favoreceu a constituição, no período pesquisa, de processos simbólicos e emocionais associados à mudança de profissão. Ao completar frases, é possível perceber essa vontade de Júlia:

19. Secretamente eu queria mudar de profissão

31. Considero que posso ser feliz em outros espaços profissionais

38. Meus estudos são importantes, mas poucos se tornaram significativos

48. O passado faria escolhas diferentes 
73. Considero que posso exercer outros papéis no meu trabalho

A docência representava para Júlia uma escolha profissional que não era o que ela gostaria de exercer. Atrelados às suas reflexões estavam os comentários que, segundo a professora, ela ouvia de amigos e outros colegas de profissão. Em entrevista, afirmou que todos falavam que tinha de estudar para outra profissão, inclusive professores da Secretaria de Educação. Amigos do seu esposo comentavam que, se trabalhasse em outra instituição, ela já teria progredido na carreira. A esse respeito, Júlia afirmou:

Todas as pessoas que me conhecem, a primeira coisa que me falam é isso: estuda e sai da Secretaria. Colega de profissão fala isso pra mim: 'você não tem que estar aqui, você tem que ir para outro lugar. Você tem capacidade de estar em outro lugar. Você está perdendo tempo aqui. Estuda pra outra coisa.' Todo mundo fala isso pra mim, a minha vida inteira. Eu continuo de teimosia (risos). (Júlia, Entrevista II).

Entendemos que as falas desses conhecidos favoreciam, em Júlia, o seu desejo de mudar de profissão, pensamentos de que poderia ser feliz, estar satisfeita, em outra área de atuação. Ao mesmo tempo, oportunizavam-lhe produções subjetivas de que era capaz de se superar, de que era uma profissional competente, alcançava os propósitos lançados. Diante dessas produções subjetivas e dos avanços dos alunos no processo de aprendizagem, compreendemos as colocações de Júlia, quando afirmou que se considerava como uma professora de sucesso, "uma professora que consegue o resultado que se espera. Então, eu não tenho essa ansiedade de mudar (de profissão). Estou numa zona de conforto. Mas eu vivo pensando numa possível falta de zona de conforto." (Júlia, Entrevista II, inclusão da autora). Para ela, a aprendizagem dos seus estudantes favorecia sua permanência na docência e o entendimento de que era uma profissional "de sucesso".

Ao ser questionada sobre esses fatores que a faziam permanecer na docência, Júlia respondeu:

Tem a coisa da acomodação. Eu gosto do que faço, eu me empolgo. Se a turma responder, então, eu vou embora. Eu gosto muito do que faço. Mas, realmente, eu confesso que eu penso muito: 'se eu tivesse em outro lugar, se eu me dedicar, se, de repente, eu não encontro a felicidade em outro campo de trabalho? Como eu falei: a pedagogia foi pra mim uma alternativa real de aprovação no concurso. Uma alternativa real de profissão. Gosto muito do que faço! Mas, será que eu não gostaria de outras coisas? Eu não sei. Eu não tive a oportunidade de vivenciar. Quando eu trabalhei no ministério público eu era muito feliz também (risos) [...]. (Júlia, Entrevista II).

Nesse trecho, a professora atribuiu sua permanência na profissão ao prazer de atuar no que gosta. No nosso ponto de vista, esse "prazer" advinha dos processos subjetivos que se constituíam no curso da elaboração e realização de suas práticas criativas no trabalho pedagógico, o que lhe possibilitava satisfação pessoal e profissional, como abordado 
anteriormente. Estas produções subjetivas indicam o valor de tais práticas criativas para a própria organização subjetiva de Júlia. Esse prazer se aliava, também, aos resultados que os alunos apresentam em relação ao seu avanço na aprendizagem.

Além disso, consideramos que lhe causavam satisfação com o seu trabalho pedagógico situações que envolviam o reconhecimento social a respeito de sua atuação profissional. Esse reconhecimento social favorecia-lhe sentidos subjetivos vinculados ao seu interesse pela docência e ao trabalho pedagógico. O comentário a seguir relaciona-se com esta construção:

É bonitinho quando meus amigos chegam: 'poxa, Júlia! As coisas que você coloca, coisas no facebook dos seus alunos, a gente nunca imagina que seja de uma escola pública'. Isso me dá orgulho. Saber que eu faço um padrão bacana dentro da realidade adversa. Mas eu confesso que eu penso como seria em outras realidades. Como seria num tribunal, estivesse no recurso humano de um tribunal, como é que seria? Ah, não sei se eu posso dizer: 'quero ser professora pro resto da minha vida! Isso é motivo de orgulho'. Não, não. Eu me orgulho do que eu faço, me orgulho do meu desempenho. Eu me orgulho da professora que eu me tornei. (Júlia, Entrevista II).

Nessas colocações, interpretamos o valor que Júlia atribuía ao reconhecimento social de sua criatividade no trabalho pedagógico, o que coaduna com outras construções provenientes da pesquisa. Para ela, os comentários positivos acerca do trabalho diferenciado que desenvolvia lhe geravam motivos para prosseguir no processo de elaboração de novidades com valor para a aprendizagem e desenvolvimento dos alunos, mobilizando-a em sua atuação profissional.

Tais produções subjetivas mantinham a professora ativa em seu trabalho pedagógico, no processo criativo e na profissão docente, constituindo-se como motivos para sua atuação profissional. Essa construção pauta-se na afirmação de González Rey (2012, p. 29), quando a autor afirma, os “[...] motivos são as configurações subjetivas que se organizam no curso da ação. As configurações subjetivas que se organizam no curso da ação sempre envolvem as configurações subjetivas da personalidade.” Em Júlia, compreendemos que, no curso do trabalho pedagógico criativo, se constituíam motivos que implicavam no seu prazer em ser professora. Ao responder a questão: se não fosse professora, seria... ela disse: "Ixiii... (pausa) Eu não consigo ver profissão" (Júlia, Entrevista I). A professora não tinha clareza quanto à outra atuação profissional que poderia exercer e acrescentou:

[...] Se fosse sair, seria pela tranquilidade de vida, porque a secretaria te suga tanto, demanda tanto, que a sua ideia de felicidade é de algo que não te sugue nada e que não te demande nada. Mas não é a real felicidade. [...] Não me vejo fazendo outra coisa [...]. (Júlia, Entrevista I).

Nesse trecho, Júlia abordou o excesso de demandas que percebia no seu trabalho pedagógico, o que, consideramos, se vinculava à sua forte exigência consigo mesma, com 
uma atuação que fosse nova e com valor para a aprendizagem e desenvolvimento dos estudantes. Ao abordar os objetivos de vida, a professora afirmou que tinha em mente um projeto exitoso em sua sala de aula: “[...] não admito que o menino saia da minha mão sem saber o alfabeto. Isso não existe! [...] No campo profissional, eu quero, hoje, ser mesmo uma alfabetizadora excelente!”. (Júlia, Entrevista I).

Para ela, esse intuito esbarrava nas condições de trabalho do professor da rede pública de ensino. Dentre essas condições, o elevado número de estudantes em sala de aula, o que dificultava, segundo a docente, a realização do trabalho pedagógico. Ao tratar acerca de suas considerações sobre o salário do professor, afirmou:

Acho que é um salário digno sim. É injusto dentro da comparação salarial com outras profissões do DF, se você pegar médico, enfermeiro, botar na tabela, aí é injusto com outras carreiras. Nível superior do mesmo jeito, função social até mais importante que outras profissões. Um técnico de enfermagem ganhando a mesma coisa que um professor! [...] Não é um salário ruim não. As pessoas se escondem atrás disso para camuflar brigas antigas, questões antigas. Então, a gente briga por salário, mas não briga para diminuir a quantidade de alunos por sala. Você pode ganhar dez mil reais, mas se tiver quarenta alunos por sala, trinta e cinco alunos por sala, com as dificuldades que a gente tem, não vai ter os mesmos resultados. (Júlia, Entrevista III).

Apesar das afirmações da professora, presenciamos no curso da pesquisa que o elevado número de alunos em sua sala de aula não se constituiu como empecilho para sua criatividade no trabalho pedagógico. Vimos que, embora a sala de informática fosse extremamente pequena, sem ventilação e condições adequadas para o uso dos computadores, Júlia a utilizava em sua dinâmica educativa; fez lá a exposição da "preguicinha eletrônica" no aparelho de data show, e alguns jogos eletrônicos relacionados à alfabetização. Além disso, realizou jogos educativos em sala de aula, produziu ela mesma jogos matemáticos, não se rendeu ao uso exclusivo de livros didáticos.

Essas situações favoreceram nossa construção de que as condições de trabalho poderiam não favorecer a criatividade da professora no trabalho pedagógico, entretanto, não se constituíam como barreiras a sua expressão criativa em sua atuação profissional. Entendemos que isso era possível porque havia em Júlia um funcionamento psicológico criativo, a geração de alternativas autônomas e singulares diante dos enfrentamentos vividos e mais, processos de (re) configuração subjetiva que viabilizavam seu movimento em prol da elaboração de novidades com valor para a aprendizagem e desenvolvimento dos estudantes.

No caso de Júlia, podemos afirmar, então, que o trabalho pedagógico se constituiu como um núcleo subjetivo que, naquele momento, estava repleto de produções subjetivas que se relacionavam à angústia, sofrimento e tensão, bem como a sua satisfação em alcançar os 
propósitos educativos que traçava para sua atuação. Contudo, não se configurou como uma tendência orientadora da personalidade, não identificamos uma projeção futura, a determinação de metas e projetos no campo profissional, aspectos que Mitjáns Martínez (2003a) relaciona à configuração, ao núcleo subjetivo da profissão como tendência orientadora da personalidade.

Ainda assim, compreendemos que havia relações entre sua atuação criativa no trabalho pedagógico e movimentos em sua subjetividade individual, o que abordaremos a seguir.

\subsubsection{Os processos de movimento na subjetividade individual da professora Júlia}

O início da trajetória profissional foi um período de desafios significativos para Júlia. Entre a formação inicial e o primeiro contato com a docência, passaram-se em torno de dois anos, nos quais ela realizou outras atividades profissionais. A entrada em sala de aula ocorreu em Brasília, quando participou do concurso para professor temporário da SEDF. Nessa experiência, atuou em uma instituição educativa considerada "modelo", que se localizava em uma área nobre da cidade, na coordenação regional de ensino que chamamos de "A".

Assumiu uma quarta série (ensino fundamental de oito anos), com alunos de onze anos de idade, em geral. Ao falar a respeito desse momento, afirmou que estava muito insegura: "Meu Deus do céu, o que eu vou fazer em sala de aula? Mas a escola era maravilhosa, o grupo de professores também. [...] Foi um ano incrível, uma coisa meio louca! Eu faço, sem ter noção!” (Júlia, Entrevista I). Disse que para os primeiros planejamentos resgatou suas memórias de estudante, conversou com os colegas que atuavam na instituição: "[...] acho que era muita intuição, e dava certo. [...]”' (Júlia, Entrevista II).

Nesse mesmo ano, Júlia havia casado e vindo para Brasília. O ingresso na Secretaria lhe possibilitava estabilidade financeira e a realização pessoal quanto à aprovação em um concurso público nessa cidade. O salário era atrativo e ela via-se na obrigação de ser aprovada: "Eu queria passar em um concurso. Não porque eu 'queria' (a Secretaria de Educação), eu queria passar em um concurso. O concurso que se apresentava como mais possível, era da Secretaria." (Júlia, Entrevista II, inclusão nossa). Para Júlia: "era muita coisa junta" (Júlia, Entrevista I).

Hipotetizamos que essa conjuntura, naquele momento, favoreceu um contexto de mudanças expressivas na vida da professora: o casamento, a vinda para Brasília, a aprovação em uma seleção, o trabalho em uma instituição reconhecida socialmente. Consideramos que 
tais experiências lhe favoreceram produções subjetivas relacionadas a um forte otimismo com sua atuação profissional e com a docência, a qual poderia se constituir como caminho possível e agradável de inserção no mercado de trabalho. A experiência nessa primeira instituição gerou, certamente, produções subjetivas relacionadas à crença nos processos de ensino, na educação, o que possibilitou sua permanência no magistério, em vez de prosseguir na área técnica-administrativa como havia atuado antes. Comentou:

Foi uma experiência destoante da Secretaria. Entrei achando que a Secretaria era aquilo ali. Falei: gente! Brasília é primeiro mundo! (risos) Perto das outras escolas. Isso gerou, claro, um impacto positivo, que fez com que eu ficasse muito feliz quando eu passei (concurso para professor efetivo). [...] Nossa! Quando eu passei, veio a realidade. (risos). Aí foi um momento de 'baque', eu tinha como parâmetro $A$ e tive que entrar numa realidade como $B$. Foi um período de embate muito grande. Pediram pra eu voltar, recebia convite para voltar (direção da instituição em que atuou como contrato temporário), mas a regional não liberou. Foi um período... Até eu aceitar, foi um período complicado. Por quê? Porque eu sabia que aquela realidade não era a certa, não era a ideal, não era isso que eu esperava. [...]. (Júlia, Entrevista II, inclusão da autora).

Nesse relato, podemos perceber o forte conflito gerado com a ida de Júlia para a região B (nome fictício), ao ser aprovada e convocada a assumir o concurso na SEDF. Essa situação envolveu a saída de uma situação educativa específica, para outra bem distinta. Interpretamos que essa mudança de instituição e de coordenação regional de ensino favoreceu a constituição de processos subjetivos que coexistiam no momento da pesquisa e que estavam relacionados ao seu desânimo e pessimismo com o ensino público. Se no início de sua atuação docente havia sentidos subjetivos associados ao otimismo com sua prática profissional, as experiências que foram vivenciadas na instituição da região B geraram a constituição de produções subjetivas vinculadas ao embate entre suas expectativas quanto à realidade do ensino público e às diferenças que percebia no cotidiano profissional.

A professora, de acordo com suas palavras, saiu de uma instituição privilegiada, em que as famílias participavam e as crianças tinham atenção e apoio em casa, para outra que se caracterizava pelo abandono familiar e social. Ao relatar esse momento, Júlia destacou:

As professoras eram extremamente dedicadas, eram extremamente... Mas, sabe? O abandono familiar. Você sai de uma escola onde, bem ou mal, as crianças têm um suporte familiar, para uma escola que não tem nenhum [...] Uma escola que não tinha parquinho, a escola não tinha informática, não tinha nada. $\mathrm{O}$ recreio dos meninos era ficar pendurado na grade, correr no pátio, não tinha nada na escola. Isso gerou um baque muito grande. Uma escola que o menino não leva material escolar, que a mãe não sabe o nome de um filho. Foi... Como se eu saísse de um extremo ao outro. O extremo de uma coisa considerada boa para o extremo de uma coisa considerada difícil, não que impedia o trabalho [...] Aqui é Secretaria de Educação, aquilo que você estava não era realidade. (Júlia, Entrevista II). 
Compreendemos que essa situação de desapontamento e decepções repercutiu em processos simbólicos e emocionais relacionados à descrença com o processo educativo e à participação de seus integrantes, tanto que ela tributou aquela situação como a predominante na SEDF. Esses processos subjetivos favoreceram movimentos de (re) configurações subjetivas, impactaram e participaram do trabalho pedagógico da professora. Provavelmente, constituíram-se produções subjetivas que se organizaram como um momento de contradição para Júlia e de reconstruções acerca de sua atuação profissional. Entendemos como contradições o que afirma González Rey (1995): aquelas situações que produzem uma tensão emocional, comprometem a pessoa com uma resposta, tornando-se força motriz do desenvolvimento. Não representam apenas atos pontuais de enfrentamento, mas verdadeiros processos ao longo dos quais se desenvolve a personalidade e muda-se significativamente o sentido do mundo para a pessoa (GONZÁLEZ REY, 1995).

No caso de Júlia, consideramos que esse momento de contradições pode ter gerado produções subjetivas que se constituíram como um processo de mudanças significativas em relação à sua atuação profissional. Conforme define Geandra Santos (2010), essas mudanças são movimentações expressivas e com certa estabilidade, que se manifestam em elementos centrais da configuração subjetiva implicada na mudança. Em outras palavras, interpretamos que em Júlia havia, inicialmente, sentidos subjetivos relacionados ao otimismo com a profissão, à crença com os processos de ensino, crença em sua possibilidade de atuar com a colaboração de diferentes integrantes da dinâmica educativa. Depois, constituíram-se outros, vinculados à descrença com o processo de ensino e à participação de seus integrantes; o desânimo e a perspectiva de mudanças no campo profissional, produções subjetivas que se formaram a partir de sua atuação docente, nos espaços sociais que participou.

O impacto subjetivo gerado por essa decepção pode ter favorecido a constituição de sentidos subjetivos como os apresentados antes, que se relacionam a dúvidas quanto à profissão, ao desejo de mudanças, à angústia e sofrimento que lhe causam. Sentidos que evidenciam o caráter histórico e atual das produções subjetivas, como afirma a Teoria da Subjetividade na perspectiva Histórico-Cultural. Em Júlia, compreendemos que as produções subjetivas que se constituíram no momento inicial de sua profissão podem coexistir no momento vivenciado pela professora durante a pesquisa, balizando os processos subjetivos que se formam no contexto atual. 
As mudanças subjetivas que se constituíram naquele período podem, também, ter se configurado como a base para a expressão criativa da professora. Ao discorrer sobre essa experiência, Júlia completou:

\footnotetext{
Fui para B. Aí foram muitos desafios. Aí eu conheci a Secretaria (de Educação) como realmente ela é. Foi a parte mais... Mas foi importante também, até para o meu crescimento, pra minha noção de Secretaria. Eu prometi pra mim mesma que ia fazer completamente diferente do que acontecia, e até hoje é assim. (Júlia, Entrevista II, grifo da autora).
}

Nesse trecho, a professora afirmou o seu intuito de atuar de modo diferente do que percebia naquela realidade educacional, ela queria diferenciar-se do que acontecia no contexto da instituição localizada na região B. Aspecto esse que pode ter sido o precursor de sua expressão criativa, relacionando-se ao movimento intencional de Júlia para uma atuação docente com vistas à promoção dos processos de aprendizagem e desenvolvimento dos estudantes, no seu movimento de produzir novidades com valor para aqueles processos.

Essa construção fundamenta-se na interpretação de um conjunto de informações, e pode ser exemplificado no relato de Júlia ao falar sobre o início da produção de atividades educativas diferenciadas para os seus alunos. Quando mudou para essa coordenação regional de ensino, assumiu uma turma de segundo ano (ensino fundamental de nove anos). Nessa experiência, citada antes, a professora percebeu-se na necessidade de concluir o processo de alfabetização de seus estudantes, dentre os quais, havia uma aluna com deficiência visual. Ao reconhecer os diferentes níveis que estavam naquele processo, Júlia se propôs a elaborar atividades que correspondessem às suas demandas, à sua aprendizagem. Ao tratar desse momento, afirmou:

Eu tive que criar. No que eu comecei a criar pra ela (aluna com deficiência visual), comecei a criar pros outros. Foi quando eu pensei na história, pensei na preguicinha. Lá a gente dividia a turma em dois grupos para a informática. [...] Era a mesma atividade, mas níveis distintos. [...]. (Júlia, Entrevista II)

Com os alunos dessa turma, a professora estabeleceu relações personalizadas, ela conhecia os processos de aprendizagem quanto à alfabetização. Essas relações, articuladas a sua organização subjetiva e aos sentidos subjetivos vinculados ao desejo de fazer diferente, favoreceram uma movimentação subjetiva em Júlia que conduziu à sua criatividade no trabalho pedagógico. Isto é, movimentos subjetivos que implicaram a produção de novos sentidos subjetivos que participaram da expressão criativa da professora, dentre os quais, produções subjetivas vinculadas à crença na sua possibilidade de ação e favorecimento de situações educativas que oportunizassem mudanças na vida de seus alunos. 
Após dois anos letivos na regional B, a professora conseguiu ir para um local mais próximo de sua residência, o que, certamente, pode ter lhe gerado processos subjetivos vinculados ao ânimo com a profissão, vigor em relação ao seu trabalho pedagógico. Nesse outro espaço educativo, Júlia teve a oportunidade de um reencontro com a docência, o que aliado as demandas dos alunos e às produções subjetivas associadas ao seu compromisso profissional, repercutiram em processos de (re) configuração subjetiva relacionadas à sua autonomia profissional e ao trabalho pedagógico criativo.

Consideramos que o ambiente social, nessa terceira instituição educativa, pode ter se constituído como um clima social que proporcionou bem-estar emocional em Júlia. Possibilitou segurança, confiança, ordem, disciplina, dentre outros aspectos, que a pessoa frequentemente não tem consciência, mas que são essenciais para os processos de formação das representações conscientes (GONZÁLEZ REY, 1995). Compreendemos, então, que os processos sociais vividos pela professora nessa instituição se organizaram em produções subjetivas que integraram núcleos subjetivos atuais de Júlia, que se desdobram no curso de suas ações em diversas áreas e em sua condição social atual (GONZÁLEZ REY, 2011a).

Esses desdobramentos repercutiram na constituição de sua criatividade no trabalho pedagógico, que possuía valor tanto para os processos de aprendizagem e desenvolvimento dos alunos, como para a própria organização subjetiva da professora. Entendemos que os processos criativos nos momentos de planejamento, produção das atividades diferenciadas para os estudantes e o próprio trabalho pedagógico criativo favoreceram-lhe a constituição de sentidos subjetivos que implicaram sua satisfação pessoal e profissional, o seu bem-estar atual em relação à docência, incluindo sua percepção de que atuava de modo diferenciado no contexto da instituição atual. Para ela: “[...] ao passo que sinto uma grande felicidade em lecionar, sinto que estou sempre em caminho distinto das minhas colegas, como se sempre analisasse as mesmas coisas de forma diferente [...]” (Júlia, Redação I).

Essa construção relaciona-se, ainda, a sua organização do trabalho pedagógico na alfabetização, que envolveu sua expressão criativa em diversos momentos no processo educativo oferecido aos seus estudantes, como explicitado antes. A primeira vez que atuou no primeiro ano do ensino fundamental foi no ano letivo de 2012, ano anterior à pesquisa. Em entrevista, relatou que na escolha de turma preferiu pegar o primeiro ano, por acreditar que os alunos chegavam à instituição em "níveis" muito próximos de aprendizagem. Comentou, ao discorrer a respeito de suas experiências na alfabetização, que:

[...] Esse ano eu estava mais criteriosa, não estava tão entusiasmada. $\mathrm{O}$ ano passado eu tinha vindo pra uma escola dificílima de você vir, estava muito querendo 'fazer e 
acontecer'. Esse ano, estava mais pé no chão, então, por um lado, deu uma 'abafada', por outro a turma me 'puxou'. Foi um ano muito bom também, eu tive resultados mais significativos esse ano que ano passado. Mas eu sinto que ano passado eu estava mais motivada, diante do contexto, estava chegando em escola nova, teve o pró-letramento, enfim, foram um monte de coisas que me deixaram em estado de ebulição. Esse ano eu ainda estou num estado bom... Mas não como no ano passado. (Júlia, Entrevista II).

No trecho acima, a professora destacou o seu interesse em desempenhar de modo satisfatório sua atuação docente: "fazer e acontecer", o que se associava às novidades que a instituição lhe proporcionava e à sua satisfação de estar naquele contexto. Interpretamos, além disso, que se constituíram necessidades educativas advindas de uma primeira atuação na alfabetização, as quais foram significativas para a implicação de Júlia em seu trabalho pedagógico, bem como para sua expressão criativa. Havia demandas que conduziram à formulação própria quanto à sua metodologia de atuação; ao mesmo tempo, a formação em serviço the oportunizou conhecimentos relevantes para que ela pudesse estruturar o seu processo de ensino. Nesse mesmo ano, participou do curso de pró-letramento em matemática, no ano anterior, já o havia cursado em língua portuguesa. Com base nesses cursos, foi organizada sua própria metodologia de alfabetização.

Nessa experiência inicial, Júlia, certamente, estava insegura quanto ao trabalho pedagógico desenvolvido na alfabetização. Em 2013, a experiência anterior lhe permitia maior domínio de práticas educativas que poderiam auxiliá-la a alcançar os resultados almejados. Em um diálogo entre ela e outra professora, observamos comentários que se relacionam a esta interpretação: Júlia comentou que, naquele ano letivo, seus alunos tinham avançado muito mais no processo de alfabetização, tinham domínio de uma série de conhecimentos que, no mesmo período do ano passado, os estudantes não tinham. A outra professora comentou que os alunos estavam, cada ano, mais espertos. Júlia respondeu com firmeza: “acho que não, eu é que estou mais segura, sei onde quero chegar!” (conversa informal). Em entrevista, reafirmou suas colocações e acrescentou: "Causa felicidade pensar que o grupo desse ano vai sair melhor do que o ano anterior." (Júlia, Entrevista II).

Em outro momento, Júlia afirmou o seu interesse pela área de tecnologia educacional, campo em que fez os seus estágios na graduação. Ao ser questionada sobre o porquê de não buscar atuar nessa área, afirmou: "me encontrei na alfabetização" (conversa informal); em entrevista, colocou também: "a sala de aula é o meu lugar.” (Julia, Entrevista II). Essas afirmações, junto às construções anteriores, nos possibilitaram a compreensão de que as experiências exitosas na alfabetização podem ter repercutido para produções subjetivas que participam de sua criatividade no trabalho pedagógico. Perceber os avanços dos estudantes, na 
escrita e leitura, pode ter sido para Júlia fonte de satisfação pessoal e profissional, mobilizando-a para a produção de novidades com valor para os processos de aprendizagem e desenvolvimento dos alunos. Sua fala a seguir nos oferece subsídios para tais construções:

\footnotetext{
Eu sempre soube da responsabilidade docente. Mas na alfabetização isso é muito forte porque é o primeiro ano, a entrada na escola. É um resultado 'palpável', o menino tem que sair lendo, escrevendo, então, é uma coisa muito objetiva [...] Está em suas mãos a chance de decodificar o mundo. (Júlia, Túnel do tempo, grifo nosso).
}

Nesse relato, consideramos, também, as implicações da forma como a função social estava subjetivada em Júlia e como isso pode ter repercutido em sua expressão criativa nas ações docentes. Interpretamos, então, que a criatividade da professora no trabalho pedagógico teve "valor" para a própria organização subjetiva de Júlia, ou seja, à medida que se envolvia no processo de elaboração e realização de suas práticas educativas criativas, constituíam-se processos simbólicos e emocionais que movimentavam suas configurações subjetivas, em especial, aqueles núcleos subjetivos relacionados à sua atuação profissional.

Essa expressão criativa favoreceu a constituição de sentidos subjetivos relacionados ao vigor da professora para a produção de novidades com valor para a aprendizagem e desenvolvimento dos alunos; a crença no processo de ensino; sua diferenciação em relação aos demais professores; o seu entusiasmo com o processo educativo; e os resultados que poderia alcançar a partir do seu trabalho docente. Isso alimentou sua implicação para a produção de novidades com valor para a aprendizagem e desenvolvimento dos estudantes e o seu entusiasmo com o trabalho pedagógico.

Compreendemos que esse processo iniciado com a turma de segundo ano e depois com as duas turmas de primeiro ano do ensino fundamental se configurou como mudanças subjetivas significativas relacionadas à criatividade da professora no trabalho pedagógico e como um momento em que ocorreram (re) configurações subjetivas decorrentes de sentidos subjetivos que se constituíram a partir do trabalho pedagógico criativo. A ponto de Júlia ver-se professora, felicitar-se com a profissão e com a aprendizagem dos alunos, formando-se motivos favoráveis a sua permanência na profissão que não escolheu propriamente.

Essa compreensão vai ao encontro do que alerta González Rey (2007b, p. 129): a "necessidade de compreender o desenvolvimento dos sentidos subjetivos em uma processualidade que não é apenas intrapsíquica, mas também integra a ação e os diferentes sistemas de relações do sujeito, assim como a organização da vida social.”. No curso da ação pedagógica criativa de Júlia, constituíram-se processos subjetivos que geravam essa satisfação 
profissional da professora com a docência, o que, em um processo recursivo, possibilitava sua própria criatividade no trabalho pedagógico. Nesse processo, consideramos que as mudanças subjetivas foram possíveis porque havia em Júlia um funcionamento psicológico criativo, em que a criatividade caracteriza-se no processo de (re) configuração subjetiva, "se expressa nas formas singulares e autônomas da ação do sujeito nos contextos sociorrelacionais nos quais está inserido" (MITJÁNS MARTÍNEZ, 2009a, p. 35). E, ainda, o que afirma Mitjáns Martínez (2008a, p. 76), ao colocar que da criatividade no trabalho pedagógico “[...] participam tanto as configurações subjetivas do professor e sua condição de sujeito, quanto as configurações subjetivas do espaço escolar e de outros espaços sociais vinculados com ele.".

\subsubsection{Considerações parciais acerca do caso da professora Júlia}

A construção das informações, no caso de Júlia, nos possibilitou a compreensão de que havia uma organização sistêmica e criativa de seu trabalho pedagógico, no qual destacamos: a formulação de uma metodologia própria de ensino; a ampliação do currículo prescrito pela instituição educativa; a elaboração pessoal de atividades educativas; e o uso da imaginação como estratégia pedagógica. Nessa professora, consideramos que se destacou o papel da imaginação como processo subjetivo, um recurso subjetivo que participava do trabalho pedagógico criativo e da geração de alternativas frente às situações pessoalmente significativas, como sua própria aprendizagem.

Na sua criatividade no trabalho pedagógico participaram, ainda, processos subjetivos relacionados a:

a) conhecimentos específicos em matemática e língua portuguesa que a professora teve acesso em cursos de formação em serviço e que se relacionavam aos campos de interesse de Júlia, que estavam articulados às demandas advindas de sua atuação profissional. Tais conhecimentos foram subjetivados por ela ao longo de suas experiências profissionais e dos processos de formação inicial e em serviço que vivenciou ao longo de sua formação docente;

b) função social da educação, tal como estava subjetivada por ela: a educação como meio para auxiliar os estudantes a ter acesso a uma gama de conhecimentos que lhes daria a oportunidade de mudanças sociais; 
c) subjetivação do papel do professor como responsável por ampliar as oportunidades de aprendizagem e, com isso, colaborar para a função social da educação;

d) subjetivação do aluno, como um ser social que participava ativamente do processo de aprendizagem;

e) forma como subjetivou a aprendizagem - a apropriação e compreensão dos conteúdos e dos conhecimentos historicamente construídos pela humanidade.

Tais processos se relacionam aos sistemas relacionais que se formavam na dinâmica educativa entre a professora e seus estudantes, os quais lhe possibilitavam a atenção aos diferentes momentos do processo de aprendizagem de cada um deles. O seu aluno era um outro social que lhe demandava novos desafios e necessidades pedagógicas, participando de sua expressão criativa no trabalho pedagógico.

Em seu cotidiano educativo, compreendemos que havia uma forte intencionalidade pedagógica. Júlia empenhava-se em alcançar os propósitos educativos formulados por ela, que envolviam o acesso aos conhecimentos históricos e outros conhecimentos de mundo. Nesse processo, ela colocava-se como autora e protagonista de seu trabalho pedagógico criativo, o que, atrelado a sua intencionalidade pedagógica, associamos a sua condição de sujeito na prática profissional.

No caso desta professora, consideramos que as produções subjetivas que se organizavam em torno da família, do forte compromisso profissional e do trabalho pedagógico eram núcleos subjetivos relevantes em sua subjetividade individual e também participavam de sua criatividade no trabalho pedagógico. Tais produções históricas e atuais repercutiam em seu interesse pela docência e a sua busca por oferecer um trabalho pedagógico criativo, com novidades valiosas para a aprendizagem e desenvolvimento dos estudantes.

No curso da elaboração e realização de suas práticas criativas foram constituídos sentidos subjetivos que se integravam à sua subjetividade individual, como apresentamos ao longo da construção das informações. Dessa forma a expressão criativa no trabalho pedagógico angariava valor para a própria professora, para sua organização subjetiva, e foi, em certo momento de sua trajetória profissional, favorecedora de mudanças subjetivas significativas. Esses movimentos subjetivos foram caracterizados por sua satisfação e realização profissional, crença nos processos de ensino, entusiasmo pela docência e permanência na profissão. 
Compreendemos, ainda, que havia em Júlia um funcionamento psicológico criativo, isto é, a geração de alternativas singulares e autônomas em diversos campos de sua vida. E que a própria constituição da criatividade no trabalho pedagógico foi expressão desse funcionamento criativo, desse enfrentamento, a geração de alternativas frente às situações que se formavam no campo profissional. Como discutimos antes, Júlia não escolheu a docência, mas diante das necessidades educativas que se constituíram, empenhou-se em oferecer um processo de ensino que fosse novo e valioso para a aprendizagem de seus alunos.

Interpretamos, com isso, que a dimensão instrumental da criatividade foi possível porque existia a dimensão funcional, uma expressão criativa que caracterizava o funcionamento psicológico da professora. Essa construção remete à compreensão de que havia em Júlia uma relação recursiva entre a criatividade em seu trabalho pedagógico e o movimento em sua subjetividade. Em outras palavras, entendemos que o seu trabalho pedagógico criativo possibilitava um conjunto de experiências que geravam produções subjetivas relacionadas à sua condição sujeito em sua prática profissional e movimentos em sua organização subjetiva. Ao mesmo tempo, consideramos que isso era possível devido à própria organização subjetiva da professora, bem como por sua expressão de sujeito, o que se manifestava em sua autoria e protagonismo no trabalho pedagógico.

\subsection{O caso da professora Laura}

\subsubsection{Quem é a professora Laura? Onde atua? Informações iniciais}

No período da pesquisa, Laura tinha trinta e três anos de idade, era casada e mãe de três filhos, com nove, cinco e dois anos de idade. Nasceu no interior de um Estado do Nordeste, sendo a segunda de quatro irmãos. Sua mãe foi professora dos anos iniciais e seu pai atuou como autônomo. Cursou o primeiro ano do ensino médio na capital do Estado e o segundo e terceiro anos em outra cidade. Veio para a cidade Brasília prestar vestibular, por considerá-la mais próxima de sua cidade natal.

Fez Pedagogia na Universidade de Brasília, formando-se no final do ano de 2002. Além da graduação, possuía curso de especialização em Psicopedagogia e iniciou outra pósgraduação, no ano da pesquisa, na Educação Infantil, um curso oferecido aos professores das instituições públicas de ensino, numa parceria entre a Secretaria de Estado de Educação do Distrito Federal - SEDF - e a Universidade de Brasília. 
Iniciou sua trajetória profissional no último ano do curso da graduação, quando, por um semestre, atuou como professora auxiliar de uma turma de educação infantil numa instituição privada de ensino. No meio do ano, contrataram-na como professora regente nessa mesma instituição. No início de 2003, foi aprovada e convocada como professora de anos iniciais na SEDF, onde atuou como professora de educação infantil, primeiro, segundo, terceiro e quarto ano do ensino fundamental (nove anos de duração).

No momento do estudo, Laura estava com uma turma de educação infantil, com estudantes de cinco anos de idade. Esse era o seu primeiro ano na instituição educativa. Trabalhava no turno vespertino e sua turma tinha em torno de vinte alunos.

\subsubsection{Contexto da instituição educativa onde Laura atuava}

A instituição educativa onde Laura atuava atendia exclusivamente alunos da educação infantil, de quatro e cinco anos de idade, que estudavam em período integral. Em um turno, os estudantes permaneciam em sala de aula e, no outro, realizavam atividades recreativas junto a professores específicos (contrato temporário). Localizava-se em uma região de classe baixa, com pouca infraestrutura e elevada violência. Durante a pesquisa, presenciamos falta de luz e água, o que impediu, em alguns dias, o atendimento aos estudantes.

Nessa instituição, havia oito salas de aulas, projetadas para o atendimento às crianças pequenas, com banheiros internos, e mobiliário adequado ao tamanho dos alunos; bebedores; um parque com grama sintética; pátio interno coberto, e neste, um palco para apresentações dos estudantes; uma sala de vídeo com televisor grande; área gramada ao redor das salas de aula; uma horta; uma sala ampla para os professores; uma brinquedoteca; um refeitório para os estudantes; e, outros espaços destinados aos professores, direção, coordenação pedagógica e atendimento da equipe de apoio (pedagogo e psicólogo).

Inaugurada há dois anos, a instituição encontrava-se em bom estado de conservação. Os espaços estavam higienizados, pintados com cores variadas, com indicativos de cuidado. As salas de aula eram amplas, possuíam armários baixos, mesas com quatro lugares, quadro negro e quadro branco e mural interno. Segundo os docentes da instituição, eram disponibilizados diferentes materiais e recursos pedagógicos: jogos, brinquedos, folhas diversas, etc., que poderiam ser solicitados para uso.

Dentre os profissionais que integravam o trabalho realizado na instituição, estavam a equipe de direção, composta pela diretora, vice-diretora, supervisora pedagógica, que estavam 
desde a inauguração da instituição, e dois coordenadores pedagógicos por turno. Estes atuavam junto aos professores e conduziam o momento de planejamento coletivo, em que era definido o conteúdo que os professores deveriam trabalhar com os estudantes. Isso ocorria em um dia da coordenação (turno contrário à regência dos professores), outro dia era destinado aos avisos administrativos, e o terceiro, à formação em serviço, que ocorria na Escola de Aperfeiçoamento dos Profissionais da Educação - EAPE.

\subsubsection{Os instrumentos da pesquisa com a professora Laura}

Quadro 11 - Os instrumentos da pesquisa com a professora Laura

\begin{tabular}{||l|l||}
\hline \multicolumn{1}{|c|}{ Instrumentos e procedimentos da pesquisa } & \multicolumn{1}{c||}{ Data } \\
\hline \hline Cenário de pesquisa & Junho/2013 \\
\hline Observações no cotidiano escolar e conversas informais & Agosto/2013 a Outubro/2013 \\
\hline Redação 1: O sentido da minha vida & Agosto/2013 \\
\hline Entrevista 1: Trajetória de vida, pessoal e acadêmica & Agosto/2013 \\
\hline Túnel do tempo & Setembro/2013 \\
\hline Completamento de frases & Setembro/2013 \\
\hline Redação 2: O sentido de ser professor & Outubro/2013 \\
\hline Entrevista 2: Trajetória profissional & Outubro/2013 \\
\hline Análise documental: atividades educativas e cartazes. & Durante as observações \\
\hline Resolução de situações do cotidiano educativo & Outubro/2013 \\
\hline Duas grandes premiações & Novembro/2013 \\
\hline Entrevista 3: esclarecimento de informações & Novembro/2013 \\
\hline \hline
\end{tabular}

Fonte: a autora (2014).

4.3.4 Expressões criativas no trabalho pedagógico: a professora Laura como sujeito de sua prática profissional

O trabalho pedagógico desenvolvido por Laura caracterizava-se como uma organização sistêmica de novidades com valor para os processos de aprendizagem e desenvolvimento dos alunos. Essa expressão criativa permeava diferentes momentos do trabalho pedagógico, dos quais destacamos:

a) a organização dos conteúdos de ensino, em que articulava as demandas advindas do planejamento coletivo e o seu intuito de ampliar as possibilidades de acesso aos conhecimentos;

b) os objetivos de aprendizagem, em que primava pelo desenvolvimento da autonomia dos alunos, sua iniciativa nos processos de escolhas e resolução de conflitos; 
c) a elaboração de atividades educativas, estratégias e métodos de ensino, em que respeitava os interesses que identificava nas falas e expressões dos estudantes e sua participação ativa na produção, realização das tarefas;

d) a constituição de um clima comunicativo-emocional que se caracterizava pela harmonia entre os alunos, segurança emocional em se colocarem e exporem suas dúvidas e o respeito mútuo que havia entre eles.

Ressaltamos que havia estreita relação entre tais aspectos no trabalho pedagógico, mas, como fizemos antes, tentaremos evidenciar, no processo construtivo-interpretativo, as produções criativas de Laura.

A professora empenhava-se, de forma nítida, em oferecer aos seus estudantes possibilidades de avanços em sua aprendizagem e a ampliação de seu conhecimento de mundo, termo utilizado no currículo nacional de educação infantil. Para tanto, buscava, em seu cotidiano educativo, articular as demandas advindas do planejamento coletivo que existia na instituição a esse intuito de ampliar o acesso aos conhecimentos, o que envolvia uma organização própria dos conteúdos de ensino.

Presenciamos, no curso das observações, como ocorria esse planejamento coletivo. Vimos que todos os professores do turno, de alunos com quatro e cinco anos de idade, reuniam-se uma vez por semana e sugeriam temas para o trabalho pedagógico. A partir da definição do assunto a ser trabalhado, cada professor organizava suas práticas educativas. Nesses momentos, Laura apontava suas indicações, argumentava e explicava suas colocações, apesar de sua timidez.

No início de agosto, por exemplo, foi definido o estudo da letra $\mathrm{S}$ a partir das lendas da Sereia Iara e do Saci Pererê. Para introduzir esse estudo, a professora selecionou um livro com o personagem do Saci, apresentou-o aos alunos e, com o auxílio de um aparelho de som, expôs a história. Além do enredo, explorou o som da letra $S$, em quais palavras conseguiam identificá-la, a cor da pele desse personagem, negra, as diferenças que existiam entre a cor da pele, as brincadeiras do Saci com os animais e a música popular chamada "Atirei o Pau no Gato”. Conversou com os estudantes a respeito dos cuidados com os animais, a importância de tratá-los bem.

Ainda na roda, no chão da sala de aula, Laura distribuiu para cada aluno um quadrado vermelho. Pegou o seu quadrado, bem maior, e foi passo a passo orientando as crianças até chegarem à figura que representava o gorro do Saci Pererê (dobradura). Abordou a figura geométrica que se formava em cada momento: o quadrado, sua diferença com o retângulo; e o 
triângulo, que representava o momento final da construção, o gorro. Durante esse processo, auxiliava aqueles que estavam com dificuldades de realizar as dobraduras. Após o término da montagem do gorro, os estudantes foram orientados a seguir para as mesas.

Os alunos realizaram atividades, como: a identificação e recorte de letras que formavam a palavra Saci, utilizando para isso revistas variadas; a representação do personagem a partir do gorro confeccionado; a escrita do nome próprio em cada tarefa; jogos de montagem e quebra-cabeça no centro da sala. Eles escolhiam a ordem de realização das atividades, e todos desenvolviam as tarefas propostas.

Essas atividades abordavam um conjunto de conteúdos, os quais extrapolavam a mera apresentação da letra e da lenda selecionada. Envolveu assuntos, como: figuras geométricas, o cuidado e respeito com os animais, as diferenças entre a cor da pele, a representação do personagem. Laura seguia o conteúdo selecionado pelo grupo de professores e agregava outros; trabalhava-os de acordo com o que julgava ser interesse e adequado para os seus estudantes.

Havia, assim, uma articulação entre os diferentes conteúdos selecionados pela professora, o que interpretamos como decorrência da organização de suas práticas educativas, do planejamento que antecedia a sala de aula. Ao responder se fazia os planejamentos de aula, afirmou: "Sento na frente da televisão e começo... (risos)" (Laura, Entrevista II). Explicou que pensava acerca das atividades educativas a serem desenvolvidas pelos estudantes, observava para que não ficassem ociosos em sala de aula. Justificou que o tempo de coordenação na instituição era pequeno, havia muitas conversas e discussões. Em casa, conseguia pensar melhor a respeito dessas atividades que poderiam realizar.

Laura, portanto, planejava as práticas de ensino, as tarefas que os seus alunos iam desenvolver. Esse processo lhe gerava, certamente, produções subjetivas relacionadas à sua segurança na condução do trabalho pedagógico, à sua criatividade. Em conversa informal, afirmou que não conseguia ir para sala de aula sem saber o que seria realizado com os estudantes. O conjunto das informações nos possibilitou compreender que para ela, pensar, planejar e organizar o trabalho pedagógico era um processo que favorecia sua segurança emocional diante dos alunos e das práticas a serem realizadas, favorecendo, ainda, sua expressão criativa, a produção de atividades que fossem novas e com valor para a aprendizagem dos estudantes.

Essa criatividade estava atrelada não apenas as produções subjetivas decorrentes do planejamento, mas, em especial, aos processos simbólicos e emocionais associados à 
satisfação profissional da professora de atuar na educação infantil. No curso de sua trajetória profissional, Laura atuou também nos anos iniciais do ensino fundamental. No entanto, reconhecia o seu interesse específico em atuar na primeira etapa da educação básica.

Ao abordar suas experiências docentes, afirmou: “[...] na faculdade [...] eu tive visitando uma série de áreas diversas. Só que a mais significativa foi na educação infantil, foi aquela que eu me apaixonei." (Laura, Túnel do tempo). No ano da pesquisa, a professora tinha voltado a trabalhar com alunos de cinco anos de idade. Ao comentar a respeito de experiências profissionais que gostaria de reviver, demonstrou uma satisfação significativa com essa retomada:

Esse ano, pra mim, está sendo tudo de bom! Mas como eu estou vivendo, não dá pra reviver! (risos) [...] Esse ano pra mim tem sido um ano dos sonhos! [...] Em relação a tudo, um espaço adequado pra educação infantil, o material, eu sinto que eu consigo uma prática que eu acredito, acho que é porque eu fiquei tanto tempo longe disso (risos), que eu estou tomando um novo ar na educação. Então, isso está me fazendo um bem tremendo! (Laura, túnel do tempo).

Interpretamos que esse "bem tremendo" que Laura afirmou relacionava-se aos sentidos subjetivos que emergiam naquele momento e que se vinculavam à sua satisfação profissional em atuar na educação infantil e à realização profissional que se constituíam no trabalho pedagógico desenvolvido nessa etapa de ensino. Essa produção subjetiva participava, possivelmente, de sua criatividade no trabalho pedagógico, contribuindo para que a professora se mobilizasse nos momentos de planejamento de suas aulas e articulasse diferentes conteúdos em seu processo de ensino.

Compreendemos que essa realização profissional relacionava-se, ainda, à forma como Laura subjetivava a função social da educação infantil, como um atendimento que possuía uma especificidade pedagógica, uma importância no processo de escolarização dos estudantes. Ao discorrer acerca de comentários depreciativos que alguns professores emitem a respeito do atendimento nessa etapa de ensino, ela afirmou: “A educação infantil é alfabetizar? Não é alfabetizar! É só brincar? Não só brincar! A gente tem que saber o que está formando [...]" (Laura, Duas grandes premiações).

Nesse processo de formação, Laura empenhava-se em articular os conteúdos sugeridos pelo grupo de professores àqueles que ela percebia como oportunos em relação ao tema trabalhado. De maneira criativa, aproveitava as situações que se constituíam e explorava outros assuntos além do que tinha sido definido, buscando uma formação que contemplasse o acesso a diferentes assuntos e permitisse uma apresentação, introdução às áreas de conhecimento. Consideramos que isso se relacionava à forma como ela subjetivava a função 
social da educação infantil, um atendimento com propósitos educativos específicos às crianças de quatro e cinco anos de idade.

$\mathrm{Na}$ história desse atendimento, coexistiram finalidades, funções distintas. Rosemberg (2005) indicou as diferentes funções da educação infantil, como: cuidado/guarda; educação/socialização; compensação de "carências"; e socialização visando projetos políticos nacionais. Para Kramer (2003) há também a tendência à função assistencialista, de guarda e proteção dessas crianças, ou como momento preparatório para o ensino fundamental.

Segundo Kramer (2006), a especificidade do atendimento na educação infantil refere-se ao contato, à experiência com o conhecimento científico e a cultura, compreendida tanto em sua dimensão de produção nas relações sociais cotidianas, quanto na de produção historicamente construída. Em sua prática educativa, Laura demonstrou uma aproximação aos aspectos destacados por Kramer (2006), isto é, a intenção de ampliar as possibilidades de aprendizagem de seus alunos, favorecendo o contato com diversos conteúdos e com o conhecimento científico.

Entendemos que esse modo de subjetivar a função social da educação, em especial, da educação infantil, evidenciava a intencionalidade pedagógica que permeava as escolhas educativas de Laura. A professora tinha o propósito de colaborar para os processos de aprendizagem e desenvolvimento de seus alunos, de acordo com as especificidades da educação infantil. Essa intenção participava de sua expressão criativa e da produção de novidades com valor para tais processos. Ao comentar acerca do trabalho pedagógico desenvolvido por alguns professores que gritam muito com os alunos, Laura afirmou:

Você ficar cinco horas, é um trabalho cansativo. Nosso trabalho é muito cansativo!
Mas se você souber o que está fazendo, se você tiver objetivo claro daquilo que você
está fazendo, se você tiver segurança daquilo que você está fazendo, aquele ali é o
melhor lugar do mundo! Eu não troco minha sala de aula por qualquer escritório, por
esses tribunais da vida, pra ficar atrás de um computador, imagina! Nunca! (Laura,
Duas grandes premiações).

Nesse relato, podemos compreender o prazer, a satisfação da professora com o trabalho pedagógico realizado na educação infantil, o que estava vinculado aos propósitos educativos definidos para esse trabalho, à função social da educação, aos objetivos selecionados por ela. Interpretamos que, para Laura, esses objetivos de aprendizagem primavam pelo desenvolvimento da autonomia dos alunos, sua iniciativa nos processos de escolhas e resolução de conflitos.

No curso das observações, entendemos que a rotina pedagógica que a professora construiu com seus alunos favorecia o desenvolvimento da autonomia de cada um deles. Laura organizava as atividades educativas em grupos, ou seja, cada mesa (com lugares para 
até quatro crianças) era destinada a uma tarefa. Em geral, havia atividades de: a) escrita, que se relacionava à representação espontânea de palavras, o registro de letras estudadas e a escrita do prenome; b) matemática, representação numérica e de quantidades; c) desenho livre ou voltado para algum tema em estudo; e d) brincadeiras com massa de modelar ou atividades de coordenação motora, como alinhavo. No chão da sala de aula eram disponibilizados jogos variados, como: quebra-cabeça, peças para encaixe, bonecos e carrinhos. Organizava, ainda, um local para leitura, com tapetes emborrachados, "pufes" pequenos e uma caixa com livros infantis.

No início da aula, Laura fazia uma roda de conversa, momento em que os estudantes contavam experiências, falavam de modo espontâneo a respeito das questões propostas pela professora. Ela participava por meio de perguntas, escutava atentamente os comentários das crianças e, ao final, explicava as atividades que seriam realizadas naquele dia. Logo em seguida, solicitava a escolha das tarefas, perguntava quem estava interessado em começar pelas atividades nas mesas e os que fariam, primeiro, as brincadeiras. Os alunos faziam as escolhas segundo o interesse de cada um deles.

Nesse processo de escolha, Laura não interferia, apenas indicava o número de alunos que poderia ter em cada atividade. Dirigia-se até as mesas, observava as produções e, quando julgava necessário, explicava novamente o comando. Após o período de realização das tarefas, os próprios alunos trocavam de mesa, verificavam os lugares disponíveis e desenvolviam a próxima tarefa. Em alguns momentos, observamos a professora falar: "já deu tempo de finalizar? Podemos trocar de mesa?". Em outros, vimos certo aluno recorrer a ela para perguntar se poderia mudar de atividade, de mesa. Laura respondia com tranquilidade que era preciso observar se havia lugar disponível e ressaltou que ele não precisava lhe pedir autorização, se já tivesse finalizado a tarefa e se houvesse lugar, poderia trocar.

Consideramos que essa organização das atividades educativas possibilitava o desenvolvimento da autonomia dos estudantes. Eram eles que escolhiam as atividades que tinham maior interesse em realizar, e todos circulavam entre as tarefas e brincadeiras disponibilizadas. A professora não precisava ameaçá-los para a realização das atividades, havia um processo de iniciativa dos estudantes, os quais determinavam a sequência de tarefas. E mais, eram eles que se organizavam nos grupos, segundo os interesses que demonstravam. O relato a seguir nos permite exemplificar essa auto-organização.

Em um dia específico, observamos a professora solicitar a um aluno que trocasse de lugar, pois ele estava brincando com massa de modelar há algum tempo. Pediu que fosse para 
outra atividade, de modo que ficasse um lugar vago e outro colega pudesse brincar. Uma aluna, que também estava nessa mesa, foi até outra e pegou uma cadeira extra para esse colega. Ela já tinha feito isso antes, pegou uma cadeira para si mesma e juntou-se ao grupo da massa de modelar. Estavam na mesa, portanto, seis crianças, e não quatro, como Laura orientava. Todas brincavam de forma harmônica, preparando uma festa para a "tia"/professora. Quando ela viu, apenas perguntou se estavam brincando "direito". Responderam que sim.

Nessa situação, interpretamos tanto a autonomia dos alunos, como a resolução de conflitos. Eles mesmos foram capazes de providenciar alternativas diante dos impasses que surgiram, de maneira que todos puderam se integrar às atividades de seu interesse. De fato, observamos raros momentos de disputas por brinquedos ou lugares nas atividades, situações tão comuns nessa faixa etária. Os alunos, ao contrário, apresentaram iniciativa de escolha, capacidade de se auto-organizarem e resolverem disputas.

Entendemos, no curso da pesquisa, que esse processo de autonomia extrapolava os limites da sala de aula e se relacionava à história de vida da professora. Durante sua adolescência, Laura morou em cidades diferentes para prosseguir em seus estudos, viveu junto a parentes. Esta situação pode ter requerido sua autonomia, a capacidade de gerar alternativas e a segurança necessária para fazer escolhas. Experiências que, possivelmente, geraram sentidos subjetivos e recursos subjetivos relacionados à flexibilidade, à iniciativa na resolução de problemas, à autonomia. Essas experiências de morar em lugares diferentes e as produções subjetivas decorrente das mesmas, podem ter colaborado para a criatividade da professora em seu trabalho pedagógico, fazendo com que ela se voltasse para o desenvolvimento da autonomia de seus alunos.

O trecho a seguir exemplifica essa possibilidade de fazer escolhas de forma responsável e autônoma, o que era incentivado pelo núcleo familiar de Laura:

\footnotetext{
Essa opção de escolha que os meus pais me deram. Em nenhum momento eles falaram assim: você vai estudar pra isso, pra ser aquilo, não. Tanto é que meu irmão, o terceiro, ele não estudou, não conseguiu entrar na faculdade e falou pra minha mãe: não vou fazer faculdade. 'O que você vai fazer? Tudo bem, não quer fazer faculdade, mas vai fazer o quê?' Agora, depois de mais velho, ele está fazendo faculdade. [...] (Laura, Entrevista I).
}

Compreendemos que essa possibilidade de escolha pode ter favorecido a constituição da autonomia por parte da professora, fazendo com que em sua atuação docente ela valorizasse e promovesse situações educativas que oportunizassem o desenvolvimento da autonomia de seus alunos. Para ela, isso era importante, direcionava a formulação de objetivos de 
aprendizagem e a organização de suas práticas educativas, permeando, também, sua criatividade no trabalho pedagógico.

Aliada à sua história de vida estava sua primeira experiência profissional. Ao discorrer a respeito do período que atuou na instituição privada, comentou: "Eu digo que 50\% do que eu sou hoje como profissional, está ali... Veio daquele espaço. Eu aprendi muito na faculdade, só que aquele espaço, pra mim...” (Laura, Entrevista I). Nessa instituição, o trabalho pedagógico era organizado em centros de interesse, o espaço da sala de aula era dividido em atividades diferenciadas, segundo as áreas previstas no currículo nacional da educação infantil. Ao ser questionada acerca de como percebia o início dessa organização do trabalho pedagógico com atividades diferentes para cada grupo, respondeu:

\footnotetext{
Surgiu de experiências anteriores. A minha primeira escola particular. A escola tinha iniciado essa proposta, ela fazia questão do rodízio. É uma prática que vinha também de questões teóricas, desenvolvimento de autonomia, iniciativa, buscar aquilo que te interessa primeiro, ou fazer o inverso, pra fazer o que me dá mais prazer depois, dá opção de escolha, tem que saber escolher também. Às vezes a gente faz escolha errada porque não tem opção. (Laura, Entrevista I).
}

Durante a pesquisa, os relatos da professora sobre essa experiência foram carregados de forte emocionalidade positiva e nos permitiram compreender a importância dessa experiência profissional para a professora e para sua organização atual do trabalho pedagógico. Interpretamos que a relevância dessa instituição está na base emocional, na segurança profissional que ofereceu à Laura. Diante da inexperiência docente, indicou-lhe um modo de atuar, um caminho para o seu trabalho pedagógico. Naquele espaço, havia o rodízio de atividades, o que foi, certamente, subjetivado pela professora e, num processo de personalização do vivido, gerou uma forma de atuar que valorizava a realização de atividades diferentes, incluindo o brincar, a leitura espontânea e a autonomia dos estudantes nesse processo de escolha.

Nessas atividades diferenciadas, os alunos tinham a oportunidade de "experimentar" propostas educativas que envolviam: desenhos direcionados e com diversos recursos, brincadeiras com jogos e quebra-cabeças, manuseio de livros infantis, recortes e colagens, dentre outras tarefas planejadas por Laura. A dinâmica da aula da professora diferenciava-se, com isso, das cenas tão comuns nas instituições educativas, em que há solicitações constantes para que as crianças fiquem sentadas, quietas. Na sua sala de aula havia a possibilidade de movimento, de escolha e ação por parte dos alunos.

Ao comentar a respeito das atividades propostas para a educação infantil, Laura afirmou: 
[...] Dentro da rede (pública de ensino) a gente tem muita essa questão do papel, de entregar pra criança aquilo pronto, principalmente na educação infantil. Ah, a Xerox quebrou: acabou a vida de muitos professores porque a copiadora quebrou. Dá o papel pra ele! 'Mas ele vai passar o dia todo desenhando?' Você constrói atividades com eles! Faz hoje um pouco, amanhã faz outro pouco, aquela atividade tem muito mais sentido pra ele. [...] (Laura, Entrevista I, inclusão da autora).

Esse relato, no conjunto de informações da pesquisa, pode exemplificar as relações entre os objetivos de aprendizagem propostos pela professora e as atividades, as estratégias e métodos de ensino. Laura respeitava os interesses que identificava nas falas, expressões dos estudantes e sua participação ativa na produção, na realização das tarefas. As atividades oferecidas para os alunos possuíam, assim, um caráter produtivo, em que lhes era solicitado que produzissem ideias, pensassem acerca de suas impressões, fizessem registros de personagens, fatos ou acontecimentos de maneira espontânea, sem se prender a modelos ou cópias.

Hipotetizamos que a forma como a professora subjetivou a importância da autonomia de seus estudantes repercutiu tanto em sua organização do trabalho pedagógico, como em sua criatividade na elaboração de atividades, estratégias e métodos de ensino, que valorizavam a produção dos alunos. Durante as observações, presenciamos o desenvolvimento de uma série de atividades educativas que nos possibilitaram chegar a essa compreensão. De modo geral, as tarefas realizadas pelos alunos de Laura tinham esse caráter ativo, produtivo, e eram elaboradas pela própria professora, a partir dos temas em pauta.

Para exemplificar nossas construções, selecionamos o período que ocorreu após o trabalho com o tema do folclore e alguns de seus personagens. Logo em seguida, Laura prosseguiu com o estudo de alguns animais. A instituição educativa havia agendado um passeio ao zoológico e, de maneira intencional, a professora articulou um estudo ao outro. Observamos, durante as conversas sobre o passeio, a construção de uma lista de dúvidas que os alunos possuíam, como a diferença entre crocodilo e jacaré, e, entre tartaruga e jabuti. Laura conversou com eles acerca de suas impressões, as experiências daqueles que já conheciam o espaço e as curiosidades dos que ainda não tinham ido ao local, e junto com os estudantes, fizeram um roteiro de estudo.

Compreendemos, nessa situação, que a professora considerou as falas dos alunos, suas dúvidas e impressões para a condução do trabalho pedagógico. Os alunos tiveram um papel ativo nos momentos antecedentes e posteriores ao passeio e na organização dos estudos decorrentes, que envolveram, além do citado, a construção coletiva de um grande gráfico em barra, que indicou os animais mais apreciados no zoológico; o estudo das curiosidades que 
demonstraram, por meio de pequenas pesquisas realizadas por ela, com imagens que possibilitavam o estudo das diferenças entre os animais elencados; a representação de alguns bichos, segundo a proporção do tamanho deles; a escrita espontânea dos nomes de alguns animais, dentre outras.

Nessas atividades, havia uma grande diversificação de materiais e recursos pedagógicos, como observamos, também, nas demais tarefas realizadas no período da pesquisa. Esses recursos possibilitavam o manuseio dos estudantes, a produção e representação ativa, segundo o que compreendiam dos assuntos em estudo. Os alunos utilizavam, com frequência, tintas guache, recorte e colagem a partir de revistas e jornais, materiais reciclados para pintura e representação de animais, papéis diversos e em tamanhos variados, alguns maiores que a altura de uma pessoa adulta.

Presenciamos, por exemplo, um momento em que duas professoras que estavam em coordenação pedagógica, no turno contrário à regência, pediram licença a Laura para observarem como os seus estudantes utilizavam tintas guache, perguntaram para ela, como eles conseguiam fazer uso desse material sem fazer "bagunça" ou se sujarem. A professora prontamente lhes explicou que havia feito orientações a respeito de como usar as tintas e, que, como a usavam com frequência, tinham aprendido a não se sujar.

Além desses materiais, Laura oportunizava o manuseio diário de jogos e brinquedos. A professora possuía um acervo considerável de materiais pedagógicos adquiridos ao longo de sua trajetória profissional. Eles eram disponibilizados para os alunos que, depois de usá-los, guardavam em duas grandes caixas que pertenciam a ela. Em entrevista, comentou que apreciava o trabalho com jogos, porque as crianças aprendiam sem se dar conta. Comentou: “[...] Às vezes os meus meninos ganham um jogo, ou eu compro um jogo pra eles, já pensando que (risos)... vai pra minha sala de aula. [...]" (Laura, Entrevista III). Alguns materiais, Laura comprou porque queria tê-los para suas aulas. Ela afirmou:

O que é da escola é de todo mundo, o que de todo mundo, não é de ninguém.
Infelizmente é assim. [...] Acaba que a gente não tem nada. E eu sou assim, quando
eu planejo uma coisa, eu quero executar como eu planejei. Então, pra mim é muito
frustrante eu querer um quebra cabeça pra fazer uma atividade e não achar o quebra
cabeça, ou achar faltando uma peça. Então, eu sei que o que é meu eu vou fechar na
minha gaveta e só eu vou usar. E aí, eu vou trabalhar com os meus alunos, a gente
vai conseguir manter aquilo ali, eu vou ter sempre a minha disposição. [...]." (Laura,
Entrevista III).

Foi possível observar que a brincadeira, os jogos e brinquedos faziam parte do planejamento de Laura, que os incluía de modo intencional em sua rotina pedagógica. Para ela, não era "caro" manter o seu acervo, mais importante que os gastos econômicos era o 
benefício, o papel de tais materiais para a aprendizagem dos alunos. Consideramos que essa maneira de compreender a importância desses materiais diversificados, se relacionava ao caráter ativo de suas atividades, estratégias e métodos de ensino. E mais, à forma como Laura subjetivou a função do professor, o seu papel no processo de ensino e aprendizagem. Ao discorrer sobre o que é a aprendizagem, afirmou:

É oferecer uma série de materiais, suportes, recursos, atividades pra que ela (aluno)
escolha como que ela quer aprender. A minha função, obrigação é dar a ela... eu não
posso ser omissa: ela vai aprender do jeito dela. Tenho que dá instrumentos. O meu
papel é dar todo o instrumento, esse suporte pra que ela escolha o jeito dela
aprender. Eu tenho que fazer o meu papel dessa maneira, não tenho que levar uma
forma pronta, uma atividade pronta xerografada [...] (Laura, Duas grandes
premiações, inclusão da autora).

Nesse trecho, interpretamos que, para Laura, cabia ao professor oferecer uma série de recursos pedagógicos para favorecer a aprendizagem dos estudantes, o que, certamente, estava vinculado à diversificação de materiais, jogos e brinquedos para as crianças e o caráter ativo que elas tinham na realização das atividades educativas. Entendemos que isso pode indicar a forma como ela subjetivava a função docente, como responsável por oportunizar situações e recursos educativos que facilitassem a aprendizagem de seus alunos. Por isso, não julgava dispendioso ter o seu próprio acervo de materiais e recursos, utilizava- os diariamente em sua rotina pedagógica.

No período das observações, vimos que, no cotidiano educativo da sua sala de aula, os alunos estavam sempre em movimento, sorrindo, conversando e realizando as atividades com nítido entusiasmo. Percebia-se "vida" nas tarefas desenvolvidas. As atividades de escritas se revezavam com jogos, quebra-cabeças, livros infantis, diferentes recursos (cola, tinta, lápis, giz de cera, dentre outros), brincadeiras, havia um dinamismo. Compreendemos que esse movimento colaborava para o interesse dos estudantes, para sua aprendizagem e desenvolvimento. A criatividade no trabalho pedagógico da professora proporcionava novidades com valor para tais processos.

Laura se envolvia no curso dessas atividades, na elaboração e planejamento das tarefas educativas que realizava com sua turma. $\mathbf{O}$ trabalho pedagógico criativo repercutia para que a própria professora se mantivesse ativa em seu papel docente, em seu interesse por produzir tais novidades. Em outras palavras, consideramos que sua expressão criativa no trabalho pedagógico possuía valor para a ela mesma. 
Essa construção se relaciona a comentários como o que Laura realizou acerca das atividades que estava planejando para a Plenarinha ${ }^{9}$, afirmou que ficou durante algumas noites sem dormir, pensando no que poderiam fazer para realizar esta avaliação.

[...] Esses dias eu estou assim... (risos) O meu cansaço é mais mental do que físico,
porque esses dias eu estou perdendo o sono nesse sentido... Eu acordo e fico
pensando: isso vai ficar assim, essa ideia de que eu vou pegar a máquina
(fotográfica), vou dar pra eles, eles vão tirar as fotos, depois eles vão representar
esse mesmo espaço que eles gostam, como eles acham que poderia ficar melhor, eles
vão fazer com desenho. Então, é assim... [...] Eu imaginei a formiga assim, mas falta
a antena, eu quero a antena. Mas, daí, eu bato o olho no material: opa! É esse aqui. É
assim que a gente vai fazer! [...] (Laura, Entrevista II, inclusão da autora).

Nesse relato, é possível evidenciar como sua expressão criativa a mobilizava, como o seu interesse em produzir um trabalho pedagógico diversificado repercutia em sua rotina, até mesmo em seu sono. Relacionamos essa mobilização aos sentidos subjetivos que se constituíam nesse processo, os quais se vinculavam ao seu entusiasmo, à sua satisfação em atuar como professora e participar da aprendizagem de seus alunos. Esses são processos simbólicos e emocionais que exemplificam o impacto subjetivo, o valor da criatividade no trabalho pedagógico para ela mesma.

Além disso, no conjunto de informações, consideramos o papel da imaginação para Laura, para o processo de elaboração das atividades educativas que oferecia aos alunos. Naquele trecho, ela afirmou: “[...] eu acordo e fico pensando: isso vai ficar assim, essa ideia de que eu vou pegar a máquina (fotográfica), vou dar pra eles, eles vão tirar as fotos, depois eles vão representar esse mesmo espaço que eles gostam [...]". Situação que exemplifica a presença de processos imaginativos no curso do planejamento das atividades e estratégias de ensino propostas pela professora. Ela imaginava como ficariam as tarefas solicitadas e isso influenciava suas decisões.

No caso dessa professora, compreendemos, então, que a imaginação permeava o seu processo de planejamento do trabalho pedagógico, colaborando para sua expressão criativa, para a elaboração de novidades com valor para a aprendizagem e desenvolvimento dos estudantes. A imaginação se constituía como um recurso subjetivo (MITJÁNS MARTÍNEZ, 2014) que se expressava na produção de propostas educativas singularizadas, de atividades pedagógicas que transcendiam a mera reprodução de informações ou modelos. E, por isso mesmo, era um recurso subjetivo e pedagógico que a professora mobilizava em seu planejamento, antecedia a realização de suas práticas educativas.

\footnotetext{
${ }^{9}$ Evento promovido pela SEDF, em que os estudantes da educação infantil são convidados para avaliarem as instituições educativas onde estudam. No ano de 2013, a turma de Laura foi convidada para representar sua coordenação regional de ensino.
} 
Desse processo imaginativo de planejar suas atividades, interpretamos que participava a forma específica como a professora percebia os seus alunos. Segundo nossas construções, para Laura, era importante oferecer materiais e recursos variados, o que favorecia a participação ativa dos estudantes em seu processo de aprendizagem. Ela imaginava como poderiam ser as atividades educativas e mobilizava-se para a produção de novidades com valor em seu trabalho pedagógico. Ao escrever acerca do sentido de ser professora, registrou: "[...] Sou APAIXONADA por este contato direto com "gente", sobretudo quando esta "gente" é uma criança, meu aluno. [...]" (Laura, Redação II). Frase que exemplifica o papel das crianças, o lidar com elas em sua profissão era fonte de satisfação pessoal e da produção subjetiva que integrava a profissão como um núcleo subjetivo relevante em sua subjetividade individual. Aspecto esse que associamos à produção de sentidos subjetivos relacionados ao prazer de atuar com crianças.

Tais processos simbólicos e emocionais participavam, ainda, da constituição de um clima comunicativo-emocional que se caracterizava pela harmonia entre professora e alunos, segurança emocional que demonstravam em se colocarem exporem suas dúvidas e o respeito mútuo que havia entre tais integrantes da dinâmica educativa. No período da pesquisa, observamos que Laura relacionava-se com os alunos de forma respeitosa, falava em baixo tom, elogiava suas conquistas, abaixava-se para conversar e orientar a realização das produções, ela se sentava no chão e nas mesas com eles.

Os estudantes, por sua vez, demonstravam respeito por Laura e atendiam as suas solicitações, como finalização das atividades propostas, conversas em baixo tom, dentre outras. Não havia brigas ou disputas entre eles, foram raras as situações que presenciamos isto, conforme comentamos anteriormente. Poucos foram os momentos em que a professora chamava a atenção de alguns alunos, em geral, porque estavam falando alto. Predominava um clima de respeito, alegria e satisfação em estar naquele espaço escolar. Consideramos que isso era favorecido pelo clima comunicativo-emocional construído na relação entre professoras e alunos, o qual gerava segurança, além de respeito e atenção uns com os outros.

Hipotetizamos que esse clima era favorecido pela criatividade de Laura no trabalho pedagógico, que proporcionava momentos de atividades dirigidas e outras livres; a sistematização de conhecimentos e liberdade de expressão (representações espontâneas); brincadeiras, a disponibilização de recursos e materiais diversificados. Essa diversificação de atividades implicava o interesse dos estudantes pelas tarefas propostas e o caráter produtivo que predominava nas práticas desenvolvidas. 
Relacionada a tais aspectos estava a forma como Laura subjetivava o seu aluno: como criança que merecia ser respeitada e considerada na organização do trabalho pedagógico. Essa construção se vincula à maneira como compreendemos suas práticas educativas, nas quais prevalecia a participação ativa dos estudantes; à importância que conferia ao brincar, o que era oportunizado por meio de brinquedos diversos presentes em seu acervo e brincadeiras realizadas diariamente em sua rotina pedagógica; aos objetivos de aprendizagem que permeavam suas escolhas educativas, como foram discutidos antes; ao papel dos alunos em seu processo de aprendizagem. Esses elementos apontam para o respeito à criança e às infâncias.

Ademais, em entrevista, a professora afirmou:

Eu vejo o aluno, assim... Como uma criança, está em formação. Tudo o que você
ensinar pra esse menino agora ele vai aprender, bom ou ruim, ele vai aprender. E é
um momento que você pode oferecer tantas coisas prazerosas [...] Então, eu acho
assim: eles estão em construção, não sou eu quem vou construir, não é o pai em
casa, não vai ser a rua que ele mora, não vai ser a escola que ele frequenta, vão ser
as oportunidades que vão ser oferecidas. A rua pode ser terrível, mas, de repente o
pai sabe a hora de ir pra rua soltar pipa com ele [...] (Laura, Entrevista I).

Para Laura, os alunos tinham uma possibilidade de aprendizagem e desenvolvimento para além de situações específicas, pré-determinadas, poderiam se formar a partir das oportunidades oferecidas a eles. Nestas, participavam tanto a instituição educativa, como as famílias e o contexto social onde os estudantes estavam inseridos. Os alunos, as crianças, participavam desse processo de construção do conhecimento. Por isso, deveriam ser considerados na organização do trabalho pedagógico, respeitados os interesses que demonstravam e sua aprendizagem.

Esse processo de aprendizagem, para a professora, era:

É um processo tão... [...] É um processo de construção e desconstrução, constrói de novo e reconstrói. Pro meu aluno aprender, eu posso até querer dá pronto, mas ele tem que experimentar. Porque o pronto que eu der, algum pode engolir, mas a maioria não vai engolir. É um processo de construção e desconstrução. Pra isso você tem que dar pra criança estímulos diferentes, porque se ela não aprender com isso aqui, vai que ela aprende com isso! (Laura, Duas grandes premiações).

Essas colocações, no conjunto das informações, nos permitiram entender que para Laura a aprendizagem foi subjetivada como esse processo de construção de conhecimentos, em que as crianças tinham um papel ativo, participavam com sua singularidade, com as formas específicas de funcionamento. Consideramos que esse processo de subjetivação, favorecia a elaboração de atividades educativas que ampliavam a possibilidade de construção de conhecimentos, segundo as especificidades da educação infantil, assim como, as relações entre a professora e os seus alunos. 
Dessas relações entre eles emergiam necessidades pedagógicas que, por sua vez, implicavam sua criatividade no trabalho pedagógico. As informações que construímos acerca da forma como subjetivava os alunos e a aprendizagem, bem como a construção que realizamos a respeito do caráter produtivo de suas atividades são interpretações que indicam o papel dessas relações para a expressão criativa da professora. O posicionamento de Laura diante de uma situação fictícia, um aluno que constantemente falava sobre desenhos animados (instrumento: resolução de situações do cotidiano educativo) pode exemplificar nossa afirmativa.

\begin{abstract}
Jamais poderia deixar de dar um espaço, ainda que um pequeno espaço, ao João, para que um tema que tanto lhe interessa seja compartilhado em sala de aula. Como educadora, acredito que, cabe a mim, buscar os seus interesses e fazer deles o meu fazer pedagógico, a fim de que de fato ocorra aprendizagem. (Laura, Resolução de situações do cotidiano educativo).
\end{abstract}

Podemos inferir que a maneira particular como Laura subjetivava a aprendizagem e os seus estudantes, como crianças que mereciam ser respeitadas, repercutiam nessa relação, no sistema relacional que havia entre a professora e os alunos e no qual se constituíam outras necessidades educativas que favoreciam sua expressão criativa. A professora estava atenta aos seus estudantes, aos interesses que demonstravam e, a partir disso, empenhava-se em oferecer situações novas e com valor para o seu processo de aprendizagem. Nessa perspectiva, incluímos a consideração, por parte de Laura, dos interesses, das falas de seus estudantes em seu trabalho pedagógico criativo, como apresentado antes. Esses aspectos associamos ao aluno como um outro social que participava da criatividade no trabalho pedagógico do professor, ao entendimento de que, no curso das relações entre docentes e estudantes, podem se formar e/ou atualizar motivos que participam dessa criatividade.

Ao longo da pesquisa, percebemos que o relacionamento que havia entre os estudantes e a professora contrastava com a maneira predominante que existia naquele espaço educativo. A instituição estava em uma área socioeconômica onde muitos docentes se recusavam a trabalhar, devido aos índices de violência, à carência familiar e financeira e aos perigos de roubos, assaltos. Por outro lado, presenciamos muitos professores gritarem com os alunos, utilizarem palavras grosseiras e desrespeitosas que, por vezes, os depreciavam. Essas situações ocorriam em momentos, como: o lanche realizado no refeitório e com muitas turmas ao mesmo tempo; deslocamentos entre os espaços, sala de aula e parque, por exemplo; pedidos para que os estudantes se sentassem e realizassem as tarefas, dentre outras.

Vimos, também, que nessas situações, Laura tendia a fechar a porta de sua sala de aula e a que dava acesso ao banheiro compartilhado com outra turma, em uma tentativa clara de 
minimizar os efeitos daqueles gritos em seu contexto educativo. Mesmo estando em um espaço institucional que desconsiderava os danos desse tipo de relacionamento entre professor e alunos, ela conseguiu estabelecer com seus alunos um clima comunicativo-emocional diferenciado, marcado pelo respeito mútuo, a presença de uma forte harmonia entre a professora e os estudantes e pela segurança emocional que demonstravam ao se colocarem e exporem suas dúvidas.

No caso de Laura, podemos hipotetizar que, mesmo diante de uma subjetividade social que naturalizou formas ríspidas de relacionamento entre professor e alunos, ela tinha desenvolvido recursos subjetivos que lhe possibilitavam gerar alternativas frente à situação vivida. Recursos esses que envolviam uma autoconfiança em si mesma e em seu trabalho pedagógico, bem como, o respeito ao aluno e à criança que ele era. Essa autoconfiança se expressava em frases como: “[...] Eu me acho uma boa professora! [...]” (Laura, Duas grandes premiações).

Tais recursos subjetivos estavam atrelados, ainda, à possibilidade que havia em Laura de gerar alternativas frente às situações vividas, o que relacionamos à expressão da criatividade em sua dimensão funcional. Para Mitjáns Martínez (2012b, p. 90) a expressão funcional da criatividade pode se apresentar nas formas de funcionamento do sujeito psicológico "[...] pela assunção de alternativas autônomas, perante situações significativas e pelas 'rupturas' singulares com o instituído no seu contexto de ação.”. No curso da pesquisa, compreendemos que a professora tinha esse posicionamento autônomo em seu trabalho pedagógico. Era ela a autora e protagonista de sua prática profissional; buscava romper com o clima comunicativo-emocional instituído naquele contexto educativo e, de maneira consciente, favorecia a constituição de um sistema relacional diferente com seus estudantes. Tais elementos nos permitiram construir indicadores acerca desse funcionamento criativo.

Consideramos, ainda, que essa dimensão funcional da criatividade expressou-se na organização dos recursos e materiais pedagógicos providenciados por Laura ao longo de sua atuação docente. Diante dos entraves e das dificuldades que se formam quando muitos professores compartilham os mesmos materiais, ela foi capaz de pensar alternativas, comprar ou selecionar alguns brinquedos de seus filhos, construindo o seu próprio acervo educativo. Tinha, com isso, os meios que julgava necessários para favorecer a aprendizagem de seus alunos.

Nessa perspectiva, interpretamos que a expressão criativa na sua dimensão instrumental era consequência de um funcionamento psicológico criativo. Isto é, a 
criatividade no trabalho pedagógico de Laura se constituía com base em dois pontos marcantes: a) no enfrentamento das situações pessoalmente significativas, o que se articulava ao seu interesse pelos alunos, à forma como os subjetivou, e por seu intuito em favorecer a aprendizagem na educação infantil; e b) na geração de alternativas singulares e autônomas de ação naquele contexto, seja em relação aos materiais e recursos, como a constituição de um sistema relacional com seus alunos pautados no respeito, seja em um clima comunicativoemocional caracterizado pela harmonia entre eles.

No processo construtivo-interpretativo, consideramos que esse clima diferenciado e a criatividade da professora em seu trabalho pedagógico decorriam de aspectos vinculados à sua subjetividade individual, tanto de sua condição de sujeito, como dos núcleos subjetivos que participavam dessa expressão criativa. E mais, as produções subjetivas decorrentes do trabalho pedagógico criativo tinham valor para a própria professora, repercutindo nos processos de configurações subjetivas, como nos aproximamos ao discutir sua expressão criativa no trabalho pedagógico, o que se tornará mais evidente no estudo de sua subjetividade individual.

4.3.5 A subjetividade individual da professora Laura: sua condição de sujeito e os núcleos subjetivos que participavam de sua criatividade no trabalho pedagógico

No estudo da subjetividade individual da professora Laura, compreendemos que, apesar da timidez, Laura posicionava-se diante dos acontecimentos vividos, imprimindo autonomia e singularidade frente às situações que se formavam. Em sua história de vida, encontramos momentos que permitem essas construções, o que inclui a sua atuação docente e a criatividade no trabalho pedagógico.

Entendemos, no curso da pesquisa, que as práticas educativas realizadas pela professora em sala de aula eram produções suas. Era ela quem elaborava, sistematizava e produzia as atividades que os seus alunos realizavam. Laura possuía um forte compromisso profissional e empenhava-se, no cotidiano pedagógico, em oferecer meios para que os estudantes ampliassem a possibilidade de aprendizagens.

Interpretamos que a condição de sujeito na sua atuação profissional se expressava por meio de sua intencionalidade pedagógica, assim como, na autoria de Laura no processo educativo, sua iniciativa e protagonismo na organização do trabalho pedagógico. A professora não se eximia da responsabilidade de educar e ensinar as crianças pequenas. Ao 
contrário, a partir da especificidade da educação infantil, voltava-se para oferecer situações educativas que favorecessem a aprendizagem e desenvolvimento de seus alunos. Para tanto, considerava as curiosidades que demonstravam, suas falas e interesses.

Laura pautava-se nesses aspectos e em seu intuito de colaborar para a autonomia dos estudantes. Elaborava suas próprias atividades educativas e organizava o seu trabalho pedagógico segundo os objetivos de aprendizagem que tinha em vista, a maneira particular como subjetivou o seu papel de professora, os alunos, a aprendizagem e a função social da educação infantil. Compreendemos que esse processo era possível porque havia um posicionamento próprio, a constituição de espaços de subjetivação, a expressão de sua condição de sujeito. Essa expressão, de acordo com González Rey (2011a, p. 215), refere-se a uma forma qualitativamente diferenciada, “[...] orientada a abrir espaços próprios de práticas e de processos de subjetivação nos diferentes grupos e instituições nos quais atua" (tradução nossa).

Tal posicionamento ocorreu, também, em outras situações a que tivemos acesso no curso da pesquisa. Laura comentou que, após quatro anos de casada, seu esposo foi convocado para assumir um concurso público em outra cidade. Ela já atuava na Secretaria de Educação, estava com o seu filho mais velho com quatro anos, e mais um bebê de dois meses de vida. A respeito desse período, afirmou: "Eu falei: como eu vou para outro Estado ficar dentro de casa cuidado de menino? Não vou! Não vou! Falei pra ele: você vai, eu aguento 'as pontas' aqui. [...]" (Laura, Entrevista I). Optou, então, por ficar em Brasília com os dois filhos. O marido vinha aos fins de semana, e depois de algum tempo, ficou grávida do terceiro filho.

Nesse momento relatado, consideramos que Laura atuou como sujeito. De forma consciente, tomou decisões relevantes que envolviam sua família e sua profissão. Não se fez "vítima" da situação, mostrou-se ativa, protagonista de suas escolhas. Vinculamos esses aspectos à definição de González Rey (2007b) em relação à expressão da condição de sujeito. Para o citado autor, o sujeito emerge na ação, na possibilidade de gerar espaços próprios de subjetivação, tomar decisões, assumir responsabilidades, implica uma posição criativa pessoal frente às situações vividas.

Entendemos que essa forma de Laura lidar com vida e com as situações vividas decorria de produções subjetivas históricas e atuais, que emergiam, também, no curso da ação e se articulavam às configurações subjetivas de sua personalidade, como aponta a Teoria da Subjetividade na perspectiva Histórico-Cultural. Tais produções subjetivas se constituíam 
como núcleos subjetivos relevantes em sua subjetividade individual, processos simbólicos e emocionais que abordaremos mais profundamente no tópico a seguir.

4.3.5.1 Os principais núcleos subjetivos da professora Laura que participavam de sua criatividade no trabalho pedagógico

No processo construtivo-interpretativo, consideramos que, entre os núcleos subjetivos que integravam a subjetividade individual da professora Laura, participavam de sua criatividade no trabalho pedagógico aqueles vinculados: à família, à exigência consigo mesma; à autovaloração e à profissão - ser professora, os quais serão tratados a seguir.

\section{A família como um núcleo subjetivo}

No curso da pesquisa, entendemos que das relações entre Laura e os seus familiares emergiam processos simbólicos e emocionais que participavam de sua criatividade no trabalho pedagógico. A forma como subjetivou o seu papel de professora pode estar relacionada ao seu próprio papel de mãe, a maneira como Laura subjetivou a maternidade. No momento da pesquisa, os seus filhos estavam na infância, eram crianças de nove, cinco e dois anos de idade, como dito antes. Nos relacionamentos com eles, certamente, se constituíam sentidos subjetivos vinculados ao seu papel de mãe, sua relevância no desenvolvimento de cada um deles e sua necessária participação ativa nesse processo. Ao completar frases, a professora afirmou:

\footnotetext{
4. Lamento não ter mais tempo para os meus filhos

16. A preocupação principal é com o futuro dos meus filhos

24. Minha principal ambição investir em uma boa educação para os meus filhos

34. Meu maior desejo é ver meus filhos felizes e bem sucedidos

41. Frequentemente, reflito sobre a educação dos meus filhos

59. Os filhos que tenho são singulares

67. Meu maior temor é não ver meus filhos crescerem
}

Compreendemos, nessas frases, que a principal preocupação e ambição de Laura estavam relacionadas aos seus filhos, que ela pensava a respeito da educação deles e investia nisso. Ao discorrer acerca do seu objetivo de vida, afirmou: “O meu objetivo agora, pro ano que vem, tirar o meu filho da escola que está, e colocar em outra. (risos)" (Laura, Entrevista I). Interpretamos que Laura tinha preocupação com os processos educativos de seus filhos, e mais, no seu papel de mãe; percebia a importância de colaborar para a educação de cada um deles; e precisava se posicionar quanto ao ensino que tinham acesso. 
Tais aspectos também estavam presentes em sua atuação docente e implicavam seu papel de professora, seu posicionamento ativo na organização do trabalho pedagógico e, consequente, expressão criativa. Hipotetizamos, nessa perspectiva, que havia relações entre o seu papel de mãe: direcionamento da educação de seus filhos, sua relevância no desenvolvimento de cada um deles; e a forma como subjetivou o papel de professora: responsável por oportunizar situações e recursos educativos que facilitassem a aprendizagem de seus alunos.

Nesse processo, integravam-se outras produções subjetivas. Dentre elas estavam aquelas vinculadas ao respeito à criança, à forma respeitosa que pode existir entre ela, criança, e os adultos. Essa construção se relaciona a comentários por parte da professora sobre as relações respeitosas que havia em seu núcleo familiar. Em entrevista, por exemplo, Laura, ao relembrar a infância, falou que o seu pai:

[...] nunca triscou o dedo na gente. Eu nunca vi meu pai alterado. Era um pai que trabalhava muito, era autônomo. A gente se reunia, na maioria das vezes, na mesa. Minha mãe, imagina! No meu irmão mais velho, ainda dava algumas palmadas. Mas, em mim, nunca! [...]" (Laura, Entrevista I).

Esse relato, cheio de orgulho, e, as falas sobre sua família, carregadas de alegria, nos permitiram compreender o respeito que havia entre eles, filhos e pais, o que, por sua vez, pode estar atrelado ao respeito pela própria criança. Consideramos que essas relações familiares, pautadas no respeito, implicavam o bem-estar emocional de Laura, sua satisfação de estar junto à família. Isto é, os relacionamentos com seus pais, irmãos e avó, bem como com seus filhos e esposo eram organizações subjetivas nas quais se constituíam sentidos subjetivos associados à realização pessoal, à segurança emocional. Ao completar frases, Laura registrou:

\footnotetext{
01. Eu gosto do sábado que almoço com meus pais

17. Desejo comprar minha casa

23. Amo minha família

36. Gosto muito da minha família

45. Luto por causas particulares e familiares

53. O lar é o meu refúgio

57. Uma mãe $e$ avó especial é a minha

60. Quando eu era criança minha avó marcou minha vida

64. Meu maior prazer está relacionado à diversão em família

66. Quando estou só assisto televisão ou arrumo guarda-roupas
}

Ao falar acerca desses relacionamentos que havia entre ela e os seus familiares, Laura relatou, ainda, que eram quatro irmãos e prevalecia a frase: "vamos se virar, vamos ajudar aqui um pouquinho [...]” (Laura, Duas grandes premiações). E que, para ela, isso foi muito importante no momento em que morou em outras cidades, longe de seus pais: "Se não fosse 
eles nesse sentido, incentivando, eu não teria me... me lançado" (Laura, Duas grandes premiações).

Interpretamos, então, que essas experiências de autonomia, tanto com seus irmãos e pais, como no período em que foi morar com parentes, podem ter colaborado para a constituição da autonomia como um recurso subjetivo, sentidos subjetivos vinculados ao intuito de favorecer a livre escolha e o posicionamento próprio por parte de seus alunos. Esses aspectos permeavam suas práticas pedagógicas criativas e os objetivos de aprendizagem que almejava em sua atuação docente. Para ela, suas prioridades educativas, como professora eram: "autonomia, dá a possibilidade de fazer... dá escolha pra criança, aprender sem perceber que está aprendendo [...].” (Laura, Duas grandes premiações).

Além disso, entendemos que a própria escolha profissional de Laura pode estar vinculada às relações familiares. Ao comentar a respeito do momento de prestar vestibular, a professora afirmou que fez o primeiro para psicologia, não passou. Depois,

\footnotetext{
Minha mãe, minha tia, são professoras. Então, nunca descartei a ideia (ser professora). Fiz o vestibular pra Pedagogia, passei e cursei. No decorrer é que eu fui gostando. No início pra mim era indiferente, eu queria passar (vestibular) logo. Para tirar de mim aquela carga de cobrança que eu mesma colocava em cima de mim. (Laura, Entrevista I, inclusão da autora).
}

Consideramos que, para Laura, o exemplo de familiares professores pode ter influenciado sua opção quanto à profissão, fazendo com que a docência fosse uma escolha possível e agradável. Entendemos que a presença de tais exemplos pode ter participado de produções subjetivas associadas ao reconhecimento e valorização da profissão: professor. Laura atribuía valor à docência e se realizava profissionalmente na atuação docente.

Entretanto, a própria escolha pela Pedagogia nos permitiu compreender, ainda, que havia em Laura processos simbólicos e emocionais relacionados à forte exigência consigo mesma. Esses processos se organizavam como um núcleo subjetivo que participava de sua criatividade no trabalho pedagógico.

\section{Exigência consigo mesma como núcleo subjetivo}

Como vimos acima, Laura afirmou, ao relatar sua escolha profissional, que: "eu queria passar (vestibular) logo. Para tirar de mim aquela carga de cobrança que eu mesma colocava em cima de mim” (Laura, Entrevista I, inclusão da autora). Depois, ao relembrar o local onde fez o ensino médio, comentou: 
Aquele lugar era tão vestibular! Estudar, ir pra escola, ia pra plantão à tarde... Porque eu me cobrava muito. Minha irmã conseguiu, eu vou ter que conseguir também. Eu tenho que estudar muito. Mas era uma cobrança particular. [...] Era uma cobrança minha, eu queria muito. (Laura, Entrevista I).

Construímos, com base na pesquisa, a compreensão de que, para ela, esse momento de ingresso no ensino superior constitui-se por sentidos subjetivos relacionados à autocobrança. Laura comparava-se à irmã mais velha, que já cursava a graduação, e almejava alcançar o ensino superior tal como ela, em uma instituição pública. Para tanto, esforçava-se em seus estudos, o que ocupava grande parte do seu tempo naquele momento. Tanto que aquela cidade foi associada a esse período: o momento de preparação para o vestibular.

Além dessa situação, compreendemos que havia em Laura uma autocobrança que se ampliava para outros campos e situações de sua vida, como sua atuação docente. Ao completar frases, registrou:

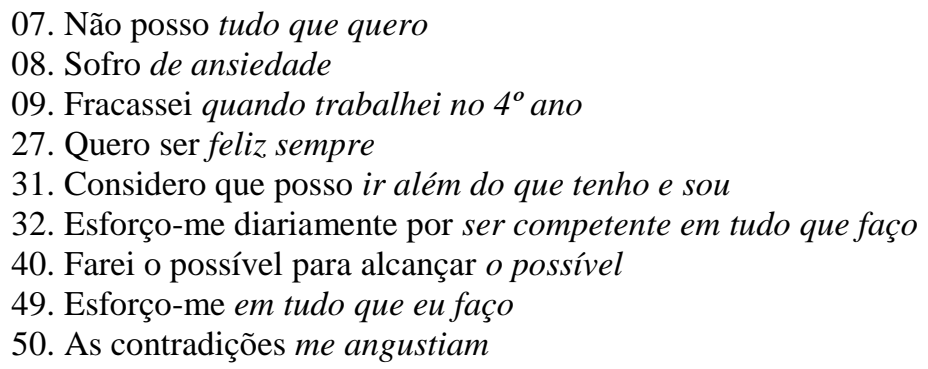

As informações da pesquisa nos possibilitaram interpretar que tais produções subjetivas vinculadas à autocobrança constituíam-se como processos simbólicos e emocionais que participavam de sua atuação profissional, tanto que poderia ir além do que era e tinha, empenhava-se em ser "competente". E mais, o fracasso estava atrelado a uma atuação profissional específica: quando atuou no quarto ano do ensino fundamental. Processos subjetivos esses que se articulavam a sentidos subjetivos relacionados à necessidade de aprovação, do reconhecimento social de seus pares.

Para Laura, ela desempenhava de forma "adequada" a sua atuação docente, era vista como "boa" professora. Havia, também, esse reconhecimento social por parte de outros profissionais. Hipotetizamos que, por isso, não ousava, não se arriscava em outras funções pedagógicas dentro do espaço escolar, nas quais poderia não ter o mesmo reconhecimento. Ao comentar acerca de outras possibilidades de atuação, afirmou que não cogitava atuar na direção de uma instituição. Não tinha vontade de trabalhar como coordenadora ou supervisora pedagógica. Acreditava que poderia contribuir em termos práticos. Entretanto, achava que o papel do coordenador estava muito desvinculado do que deveria ser. E, mais: 
Eu tenho muito medo... Eu sou muito profissional. Eu sei que o meu trabalho é reconhecido pela escola. Onde eu passo o meu trabalho é reconhecido pelos meus colegas de trabalho. E eu tenho muito medo, receio de sujar essa imagem. Por que a gente sabe que, muitas vezes isso acontece, porque o papel desses profissionais é muito assim... hoje ele é isso, amanhã é aquilo [...] Aqui nessa escola eu tenho sentido que ele é, pelo menos, o que deveria ser. (Laura, Entrevista II).

Consideramos, então, que, para Laura, esse reconhecimento social por parte de outros docentes participava de sua criatividade no trabalho pedagógico, gerava processos simbólicos e emocionais que se integravam em sua autoimagem de professora competente. No trecho acima, é possível observar: "Eu sou muito profissional. Eu sei que o meu trabalho é reconhecido pela escola.” (Laura, Entrevista II). Em sua organização subjetiva, tais processos subjetivos se articulavam em uma forte exigência consigo mesma, mobilizando-a em prol de sua própria superação profissional.

Para a professora esse reconhecimento social era importante e a instigava a produzir novidades com valor para o processo de aprendizagem dos estudantes. Ao mesmo tempo, essa expressão criativa oportunizava produções subjetivas que se organizavam em sua subjetividade individual, tinham valor para ela mesma, possibilitando a constituição de sentidos subjetivos associados à superação em sua atuação docente, em sua criatividade no trabalho pedagógico. Esses processos subjetivos se aproximam do que Mitjáns Martínez (2003a) também identificou em outros profissionais criativos: orientação muito ativa para a superação no desempenho profissional

Essa construção, no caso de Laura, apóia-se em algumas situações presenciadas durante a pesquisa. Dentre elas, a conversa informal com a vice-diretora, a qual comentou que percebia nos demais profissionais da instituição um direcionamento diferenciado após a chegada da professora na instituição, tanto em relação aos trabalhos educativos oferecidos aos alunos, como à confecção dos murais, que passaram a contar com mais produções das crianças. As demais docentes percebiam as diferenças entre o trabalho pedagógico de Laura e aprendiam com ela, estavam mudando as tarefas educativas e, consequentemente, a exposição das atividades nos murais.

Laura também percebia o impacto de sua proposta educativa naquela instituição. Consideramos que essa percepção lhe gerava esse intuito de superação, tais produções subjetivas relacionadas à superação em sua atuação docente e sua expressão criativa. Ao ser questionada sobre a forma como via o seu trabalho pedagógico naquela instituição, comentou:

É uma alegria perceber isso! Eu fico toda, toda... (risos) Cheia de mim! [...] Aquele mural lá (referiu-se ao mural em relação à primavera). Eu nunca tinha trabalhado com mural feito de sucata... Logo no começo quando cheguei aqui, não tem nem um ano, você via na parede tarefinha xerografada dos meninos, só tarefa xerografada. 
Eu não trabalho com tarefa xerografada, então, eu não tinha tarefa xerografada para colocar lá. Eu comecei a colocar as minhas tarefas, só que assim... sem pretensão nenhuma, era o trabalho que eu fazia. Não era para colocar a produção dos meninos, o que eles faziam? Então, o mural era cheio de tarefas xerografadas. Mudou muito, mudou muito! Aí, você também tem vontade de se superar nesse sentido, se faziam assim e agora estão chegando perto, então, vamos fazer diferente também? Eu falei, vou pegar sucata, vamos inventar, fazer diferente isso aí. Então, sim, isso é motivação pra mim o tempo todo. (Laura, Entrevista II).

Entendemos que esse trecho exemplifica o impacto subjetivo dessa compreensão acerca do seu trabalho pedagógico e, como isso, a mobilizava a ousar mais, tentar outros recursos e estratégias que ainda não tinha utilizado. As produções subjetivas decorrentes de sua criatividade no trabalho pedagógico angariavam valor, portanto, para o próprio funcionamento psicológico de Laura, bem como para aqueles professores presentes na instituição educativa.

Por outro lado, compreendemos, no processo construtivo-interpretativo, que essas produções subjetivas relacionadas à superação na atuação docente e à criatividade no trabalho pedagógico constituíam-se como uma forte exigência consigo mesma. Ao registrar o sentido de ser professora, Laura afirmou:

Como não sou só professora, diversas situações do dia-a-dia me cansam, levandome a pensar que muito mais fácil seria lidar com elas atuando em outra área, já que um problema pessoal tende a me afetar ao ponto de trazê-lo para minha sala de aula. Sabendo da responsabilidade da minha prática, me sinto muito mal quando isso ocorre. (Laura, Redação II).

Nessas frases, a professora expressou tanto exigência quanto à sua atuação profissional, como ainda o desapontamento com ela mesma diante do seu cansaço e das repercussões emocionais que problemas familiares causavam em seu trabalho pedagógico. Esse desapontamento se relacionava à constituição de sentidos subjetivos vinculados à frustração, ao fracasso, diante de situações que a levavam a sentir-se impotente. A situação relatada envolvia o forte compromisso profissional e a compreensão de que momentos pessoais poderiam intervir em sua atuação docente.

Tais produções subjetivas se constituíam, também, diante de projetos não realizados. Ao discorrer a respeito do seu interesse em prosseguir em seus estudos, em realizar o curso de mestrado, Laura afirmou que, antes, queria muito, mas que atualmente, já não desejava mais: "Eu sei, nem estabeleço como meta, porque eu me conheço. Eu fíco ansiosíssima. Se eu estabeleço essa meta e eu não consigo essa meta, eu sofro demais. Então, eu não estabeleço como meta. Um dia, vai acontecer" (Laura, Entrevista I). Relato esse que, no conjunto das informações, nos permitiu compreender a constituição de sentidos subjetivos associados ao fracasso, que se organizavam em sua forte exigência consigo mesma. 
Compreendemos que esse núcleo subjetivo participava de sua criatividade no trabalho pedagógico e repercutia na constituição de sentidos subjetivos que se organizavam na autovaloração de Laura. Esses processos subjetivos se integravam à sua expressão criativa no campo profissional.

\section{Autovaloração como núcleo subjetivo}

Como vimos antes, Laura acreditava em seu trabalho pedagógico, tinha convicção de que era uma boa professora. Naquele momento, evidenciamos que essa convicção estava relacionada ao reconhecimento social acerca de sua atuação docente, ao que ela percebia em seu espaço profissional, aos comentários que outros profissionais faziam em relação às suas práticas educativas; e que isso lhe favorecia uma forte exigência consigo mesmo, ao processo de superação em seu trabalho pedagógico e a sua expressão criativa.

Atrelado a tais aspectos, consideramos que havia em Laura produções subjetivas relacionadas à sua autoavaliação, a processos reflexivos de que sua atuação docente e os objetivos de aprendizagem que propunha para sua turma favoreciam a aprendizagem e desenvolvimento de seus alunos. Ao falar acerca do seu trabalho, a professora afirmou: “Acreditar naquilo que eu faço. E isso me faz tão bem! O trabalho me faz muito bem. Então, ele me alimenta. [...] Eu acho que você ter clareza dos seus objetivos, isso favorece muito, isso sustenta o seu trabalho. 'Isso alimenta'.” (Laura, Duas grandes premiações).

Nessa situação, retomamos sua afirmação sobre o seu trabalho, questionamos se a atuação profissional, como professora, lhe fazia bem. Laura respondeu com firmeza: "Demais da conta, demais da conta! [...] Quando eu faço o que eu gosto, então! Eu sinto que na educação infantil eu desenvolvo o meu trabalho com excelência. Eu consigo dar tudo de mim. [...] Eu me acho uma boa professora [...]" (Laura, Duas grandes premiações). No curso da pesquisa, interpretamos, então, que o trabalho pedagógico criativo favorecia a constituição de sentidos subjetivos relacionados a uma autoavaliação de forma positiva, e que isso, certamente, estava associado à satisfação a que se referiu: “[...] o trabalho me faz muito bem $[\ldots] . "$

Esses sentidos subjetivos participavam de sua criatividade no trabalho pedagógico, de sua autoimagem, como profissional competente. Tanto que para ela, não havia outra alternativa quanto ao trabalho, ela desempenhava com êxito suas funções docentes, não havia fatores que implicassem mudanças profissionais. Nessa perspectiva, a despeito do 
reconhecimento da desvalorização da profissão docente, afirmou, ao registrar o sentido de ser professora, que: "Na minha trajetória profissional, apesar das situações acima descritas (em relação à desvalorização da docência), JAMAIS pensei em fazer outra coisa, uma vez que faço o que gosto e sei fazer." (Laura, Redação II, inclusão da autora). Consideramos nestas frases, e em diferentes momentos da pesquisa, que Laura demonstrou ter uma crença em sua atuação docente, no seu trabalho pedagógico, produções subjetivas que se articulavam a sentidos subjetivos associados a sua autoconfiança como boa professora.

No processo construtivo-interpretativo, compreendemos que estas produções subjetivas a respeito da crença em sua atuação docente, sua autoconfiança, constituíamse como motivos para sua criatividade no trabalho pedagógico. Isso a mantinha ativa nos processos de elaboração e realização de suas atividades educativas, no processo de produzir novidades com valor para a aprendizagem e desenvolvimento de seus alunos. Assim, embora percebesse as diferenças entre sua proposta educativa e a que predominava no contexto daquela instituição educativa, a professora prosseguia na elaboração de suas próprias tarefas, na organização de um trabalho pedagógico que buscava os objetivos de aprendizagem traçados por ela.

Hipotetizamos que esses motivos se relacionavam, ainda, a outros sentidos subjetivos associados à segurança em si mesma como profissional. Laura, ao longo de sua trajetória profissional, atuou em diferentes instituições educativas, o que inclui uma instituição privada. Nesses espaços, desenvolveu atividades profissionais em diversas séries, tanto no ensino fundamental como na educação infantil. Experiências profissionais estas que, em sua diversidade, podem ter favorecido à constituição dessa segurança em si mesma como profissional. Ao discorrer a respeito de tais experiências, afirmou: “[...] Se eu voltar na escola A, eu sou recebida super bem. Onde eu passar, eu sou recebida muito bem." (Laura, Entrevista I). Essa frase que exemplifica nossa construção acerca dessa segurança em si mesma que Laura possuía.

Essa segurança se relacionava aos processos reflexivos que Laura empreendia sobre o seu trabalho pedagógico, à sua orientação ao aperfeiçoamento de sua prática docente. A professora planejava suas ações educativas e, ao realizá-las, colocava-se nessa possibilidade de mudança do que havia previsto. Durante a pesquisa, percebemos essa orientação. A situação citada antes acerca da Plenarinha pode exemplificar essa construção.

Nas atividades educativas que tinha proposto para esse evento, a professora confeccionou, junto aos alunos, uma maquete da instituição educativa; elaboraram um livro, 
em grandes dimensões, que tinha registros de como os estudantes pensavam a organização do espaço escolar, mudanças sugeridas por eles; fizeram fotografias do que gostavam ou não na instituição, dentre outras produções.

Nesse processo, houve a realização de uma diversidade de atividades educativas, o que, entendemos, foi possível porque Laura planejava o seu trabalho pedagógico, pensava sobre ele. Desse processo reflexivo, participavam sentidos subjetivos vinculados à sua autonomia docente, os quais integravam tais reflexões acerca do trabalho pedagógico proposto e realizado. E mais, havia a flexibilidade necessária para propor suas próprias atividades. Para Laura, ela era a autora de seu trabalho pedagógico, a protagonista das seleções, das escolhas educativas. Por isso, existia essa possibilidade de criar, de transformar o planejamento, o que, em conjunto com outras informações, nos permitiu interpretar a flexibilidade como um recurso subjetivo que integrava sua expressão criativa.

Consideramos que essa produção subjetiva, junto às demais citadas, organizava-se em um núcleo subjetivo específico: a autovaloração, o qual também participava da criatividade de Laura em seu trabalho pedagógico. Nele integravam-se, ainda, outros processos simbólicos e emocionais que se organizavam em um núcleo subjetivo específico: a profissão - ser professora.

\section{A profissão como núcleo subjetivo}

No caso de Laura, o núcleo subjetivo que se organizava como sua autovaloração estava repleto de processos simbólicos e emocionais relacionados à profissão docente. Ser professora participava de sua autovaloração, dos processos subjetivos que se constituíam e se organizavam nesse núcleo de subjetivação. Essa articulação evidencia a complexidade da subjetividade humana, na qual, segundo González Rey (2007b), há essa possibilidade dos sentidos subjetivos e das configurações subjetivas se atravessarem uns aos outros. Para o citado autor, "um sentido subjetivo pode se converter em uma configuração subjetiva ao integrar um sistema de sentidos subjetivos diferenciados em torno de si, em determinado contex to [...]” (GONZÁLEZ REY, 2007b, p. 136).

De fato, a profissão - ser professora - possuía, para Laura, grande peso em suas produções subjetivas, como podemos interpretar ao longo da construção das informações apresentadas até o momento. O peso dessa produção subjetiva acerca de sua profissão nos conduziu à compreensão de que ela era um sentido subjetivo que integrava um sistema de 
outros sentidos subjetivos em torno de si, entre os quais, aqueles vinculados à identificação com a profissão.

Laura via-se como professora e reconhecia a docência como parte significativa de sua vida. Ao discorrer a respeito de suas experiências de vida, relatou: “A minha profissão é... ela é $50 \%$ do que eu sou. Não tenho dúvidas! É minha identidade, é uma parte significativa da minha identidade. Não sei fazer outra coisa" (Laura, Entrevista II). Atrelados a suas palavras, reconhecemos trechos no completamento de frases, que sustentam nossa construção de que a profissão tinha um o papel significativo em sua organização subjetiva:
6. Na escola amo a minha sala de aula
13. Estou melhor, muito melhor que há alguns anos atrás
15. Este lugar me faz um bem tremendo!!!
18. Minha profissão é uma parte IMPORTANTÍSSIMA da minha vida
22. O trabalho me faz muito bem
29. Esse ano letivo tem sido um marco na minha vida profissional
42. Proponho-me a ajudar na formação integral dos meus alunos
43. Meu maior tempo dedico ao meu trabalho e a minha família
47. As crianças me fazem o maior bem do mundo, mas também me esgotam
54. Incomoda-me tarefas xerografadas
56. A gente é feliz fazendo o que ama
68. Se trabalho é porque preciso e gosto
72. Meu grupo é nota 10!!!

Nessas frases, Laura afirmou que a instituição educativa lhe fazia um "bem tremendo", assim como o trabalho. Ao conversamos em entrevista a respeito de tais questões, compreendemos que, para ela, aquele espaço educativo representava o retorno à educação infantil, etapa de ensino que mais apreciava. E que trabalhar ali, naquele contexto, estava lhe oportunizando a constituição de sentidos subjetivos relacionados ao seu bem-estar, sua satisfação e realização no campo profissional. Por isso, mesmo reconhecendo as dificuldades de atuar naquela instituição, como a distância de sua residência e o comportamento agressivo da comunidade e dos professores, Laura mostrava-se feliz e realizada com o trabalho desenvolvido junto à sua turma. Lá, ela havia reencontrado um contexto educativo que lhe possibilitava organizar o seu trabalho pedagógico segundo suas crenças; existia essa liberdade na atuação docente criativa.

Além disso, a professora estava atuando na etapa da educação básica com a qual identificava o seu perfil profissional: a educação infantil. Ao tratar de experiências, em sua trajetória docente, que gostaria de transformar, citou os momentos em que trabalhou com as turmas de terceiro e quarto ano do ensino fundamental. Relatou que quando começava a trabalhar fora da sequência prevista no livro didático, desenvolvendo atividades elaboradas por ela, sua turma ficava atrasada em relação às demais. Ao falar dessas experiências afirmou, ainda: "Eu fiquei devendo alguma coisa pra elas, não sei o quê! [...] Não sei se a dívida era 
com eles ou comigo mesmo [...] Estava ao lado de casa, mas era um tormento ir pra escola. [...] As condições de trabalho eram péssimas!” (Laura, Túnel do tempo). Para ela, essas foram experiências que “[...] mereciam ser transformadas. [...] Não sei se eu daria conta de transformar essas experiências. Acho que eu não daria. Eu não dava conta!” (Laura, Túnel do tempo).

Compreendemos que tais experiências no ensino fundamental não lhe permitiram ser autora de seu trabalho pedagógico, criar suas próprias atividades educativas, elaborar estratégias novas e com valor para a aprendizagem de seus alunos. Foram momentos que limitaram sua expressão criativa, seja pelas condições de trabalho, seja pelo currículo previsto para tais séries. Tanto que, para ela: "O ano passado, o pior lugar era a minha sala de aula." (Laura, Entrevista I), citando o período que estava como professora do quarto ano do ensino fundamental.

$\mathrm{Na}$ educação infantil, Laura sentia-se mais livre para sua autoria e, certamente, mais segura para criar o seu trabalho pedagógico, de acordo com os objetivos de aprendizagem que almeja em sua atuação docente. Ao fazer referências ao melhor lugar, foi enfática ao afirmar que gostava muito da sua sala de aula: “[...] Esse ano está sendo um ano de 'respiro', de muita satisfação [...]. Hoje um lugar bom é a minha sala de aula, é o melhor lugar. Minha casa também. [...]" (Laura, Entrevista I). Em outro momento, reafirmou: "gosto demais do meu ambiente de trabalho! Gosto demais da minha sala de aula! Esse ano, especificamente, eu estou muito feliz! Muito feliz!” (Laura, entrevista I). Informações que nos possibilitaram inferir o papel da criatividade no trabalho pedagógico para o bem-estar emocional da professora, o valor que as práticas criativas tinham para o seu funcionamento psicológico.

Nesses processos de elaboração e realização das atividades educativas novas e com valor para a aprendizagem dos alunos, constituíam-se produções subjetivas que se tornavam motivos para sua atuação profissional. Tanto que ao ser questionada: se não fosse professora seria..., ela respondeu após uma pausa: "Eu queria trabalhar na área de educação. Eu fiz psicopedagogia. Pensei, uma vez, em psicopedagogia clínica" (Laura, Entrevista I). Percebemos, então, que, apesar de não ter interesse em trabalhar em outras funções dentro do espaço escolar, Laura buscaria a educação, o que relacionamos aos sentidos subjetivos vinculados à realização e satisfação profissional que se formam a partir e com base em trabalho pedagógico criativo. 
Essa realização e satisfação profissional articulavam-se aos sentidos subjetivos associados ao prazer de dar aulas, de ser professora e estar em contato com as crianças. Para Laura:

\begin{abstract}
A minha realização, o meu prazer é com a sala de aula, com todas as dificuldades que tem lá dentro. Às vezes, a dificuldade não está lá dentro, está fora: no pai que não entende o que você está fazendo, na direção, no outro colega que acha que você... 'Como ela está trabalhando se não deu uma folha xerografada pro menino, se ela nunca pede material rodado?' Às vezes a dificuldade não está lá dentro, a dificuldade maior está lá fora [...]. Aquilo ali é meu espaço de prazer. (Laura, Duas grandes premiações).
\end{abstract}

Entendemos que, no caso de Laura, sua expressão criativa e as produções subjetivas que decorriam de seu trabalho pedagógico criativo lhe proporcionavam processos simbólicos e emocionais que lhe permitiam ter convicção de sua escolha profissional. Esses aspectos favoreciam sua autoria, o seu protagonismo, mantendo-a ativa em suas práticas educativas, na elaboração e produção de suas atividades, enfim, na organização do seu trabalho pedagógico.

Para ela, o reconhecimento social de sua atuação, bem como de sua profissão eram relevantes para sua autovaloração. Ainda assim, a professora não questionava sua profissão, diante da desvalorização que percebia acerca da profissão - ser professor, afirmou:

\footnotetext{
Minha primeira experiência profissional já se deu na educação, no início, como monitora de um projeto de EJA (Educação de Jovens e Adultos). Costumo dizer que já aí me descobri professora. No decorrer dos anos, novas experiências na área foram vividas e cada vez mais tenho sido tomada desta certeza. (Laura, Redação II, inclusão da autora).
}

Ao discorrer sobre essa desvalorização, Laura comentou a respeito de sua percepção de que os próprios professores não reconhecem a profissão, e mais, desvalorizam a educação infantil. Muitos falam que o professor dessa etapa: "só brinca, tem a vida boa, fica a toa. [...] Os pais te enxergam como cuidadora, você não tem esse lado profissional.” (Laura, Entrevista II). Situações estas que se atrelam à desvalorização que percebia em seu ambiente familiar, em especial, por parte de seu esposo. Ao ser questionada se conversava com ele acerca das atividades que desenvolvia, respondeu: "Não. Porque ele é daqueles que... educação infantil, né? Sabe..." (Laura, Entrevista II).

Hipotetizamos que, diante de tais situações, Laura apoiava-se em recursos subjetivos vinculados à sua autoconfiança em si mesma como profissional, à sua autovalorização. Frente à pergunta sobre como se sentia nesse contexto de desvalorização por seu marido, respondeu: "Eu aprendi a ignorar, e sei o que estou fazendo, aprendi a ignorar." (Laura, Entrevista II). Resposta que, no conjunto de informações, indicou o papel da profissão para a professora, a importância das produções subjetivas que se constituíam em seu trabalho pedagógico para sua autoconfiança e bem-estar emocional. 
No momento da pesquisa, Laura estava atuando em uma instituição educativa que atendia exclusivamente a educação infantil, foi planejada para o atendimento dessa etapa da educação básica. Nesse contexto, os efeitos da desvalorização do atendimento às crianças de quatro e cinco anos estavam minimizados na subjetividade social dominante daquele espaço. A professora reconhecia isso, o que podemos interpretar a partir de falas como esta, em um “centro de educação infantil estamos todos no mesmo 'barco', a gente conversa na mesma 'língua'. Aqui está tudo voltado para essa faixa etária. Isso é muito bom! Esse ano eu não tenho sentido isso." (Laura, Entrevista II).

Interpretamos, com isso, que o espaço escolar onde Laura estava atuando no período da pesquisa e as relações com outros colegas, também professores da educação infantil, geraram, certamente, sentidos subjetivos vinculados ao reconhecimento e valorização de sua atuação na educação infantil. Entendemos, ainda, que tais produções subjetivas junto aos processos subjetivos associados ao bem-estar emocional e à realização profissional que emergiam do trabalho pedagógico criativo, favoreciam em Laura a formação de projeções futuras relacionadas à docência. Ao completar frases, a professora afirmou: Minha vida futura é bem previsível. Ao falar acerca de projetos futuros, expôs que tinha interesse em atuar no ensino superior. Ficava fascinada com a figura do professor universitário, teve bons professores na graduação:

[...] acho uma coisa assim fantástica, uma coisa muito bacana [...] Tenho vontade de fazer um mestrado, seguir na área acadêmica. Pra mim, essa retomada com esta especialização... Eu não vou ganhar nada em termos financeiros, mas pra mim tem sido um fôlego novo [...] (Laura, Entrevista II).

Em Laura suas projeções futuras estavam vinculadas ao trabalho pedagógico, o que, junto às demais construções realizadas em seu estudo de caso, nos permitem compreender que a profissão - ser professora - constituía-se como tendência orientadora de sua personalidade. Isto é, no curso do trabalho pedagógico criativo emergiam sentidos subjetivos que se tornavam produções subjetivas nucleares em sua personalidade, esses sentidos subjetivos estavam associados ao bem-estar emocional, à realização e satisfação profissional. Geravam, em sua organização subjetiva, motivos para sua atuação profissional, implicando o movimento intencional da professora para a elaboração e produção de atividades educativas novas e com valor para os alunos. Essas atividades, por sua vez, atualizavam outros processos subjetivos relacionados à sua atuação docente.

Nessa perspectiva, consideramos a afirmação de González Rey (2007b, p. 135): “[...] a criatividade sempre representa uma possibilidade de produção de sentidos subjetivos diferentes que permitem ao sujeito desenvolver o sistema complexo da ação criativa.". No 
caso de Laura, havia alto grau de desenvolvimento da motivação para a profissão, a qual se configurava como um importante meio de auto-realização, conforme Mitjáns Martínez (2003a) também identificou em profissionais criativos. Profissão esta que, por meio de suas experiências criativas, oportunizou produções subjetivas que geraram o movimento na subjetividade individual da professora Laura, segundo as construções a seguir.

\subsubsection{Os processos de movimento na subjetividade individual da professora Laura}

No processo construtivo-interpretativo, consideramos que para Laura o trabalho pedagógico criativo era meio de produções subjetivas que se relacionavam ao seu bem-estar emocional, sua satisfação e realização profissional, em especial, quando esse trabalho ocorria na educação infantil. Esse processo subjetivo vinculado à sua satisfação com o trabalho pedagógico criativo na educação infantil pode estar relacionado às suas primeiras experiências docentes, aos impactos subjetivos que decorreram das relações pessoais e da aprendizagem iniciada por Laura referente ao ser professora.

Ao relembrar as experiências no campo profissional que gostaria de reviver, Laura comentou a respeito da instituição privada onde iniciou sua trajetória docente. Afirmou que tudo nesse espaço era diferente, estava em sintonia com os estudos da faculdade. E mais:

\footnotetext{
A minha primeira experiência muito significativa, foi a primeira escola que trabalhei, na educação infantil. São experiências que assim: às vezes, eu me pego sonhando voltando pra essa escola. Acho que nem existe mais, já está... Foi a minha primeira experiência, me marcou muito. Eu tenho esse viés pra área de educação infantil. Não sei se foi essa experiência que me construiu assim, ou se ela só agregou, me fez descobrir esse lado. E aí, fui buscar... não sei. Essa escola, em específico... Às vezes, eu sonho que estou largando a Secretaria de Educação e voltando pra escola. (Laura, Túnel do tempo).
}

No curso da pesquisa, Laura fez muitas referências a esse momento em que atuou na instituição citada, o que, aliado às suas colocações nesse trecho, nos permitiu compreender a relevância dessa experiência para sua profissão, para sua constituição como professora. Associamos essa relevância aos impactos subjetivos gerados, ao fato desse período ter sido palco da constituição de processos simbólicos e emocionais relacionados à conquista de uma profissão, à satisfação pessoal de ter ingressado no mercado de trabalho. Para tanto, ela havia se esforçado, se dedicado bastante aos seus estudos e aprovação no vestibular. Havia deixado sua cidade natal e sua família.

No início da carreira docente, Laura atuou com a educação infantil, aprendeu a ser professora com as crianças de quatro e cinco anos, situação que, pela produção subjetiva 
gerada, pode ter colaborado para sua identificação com essa faixa etária. Naquele contexto educativo, segundo relato da professora, não havia atividades xerografadas, os docentes eram convocados a elaborarem suas atividades educativas, observar os interesses das crianças e organizar o seu trabalho pedagógico em centros específicos (brincar, conhecimento de mundo, etc.), conforme previa o currículo da educação infantil. Essa experiência foi, possivelmente, o que balizou a maneira como a professora subjetivou sua atuação docente, caracterizada pela possibilidade de criação, de criatividade no trabalho pedagógico. Por isso, julgava identificar-se com a educação infantil, etapa que lhe permitia produzir novidades, elaborar suas próprias atividades educativas, segundo o que havia compreendido sobre o trabalho pedagógico nessa etapa de ensino. Para ela:

\begin{abstract}
A prática pedagógica foi muito diferente de tudo o que você via por aí. Pelo menos naquela época, época de faculdade, de você ir pra escola observar isso, observar aquilo, estava muito em sintonia com aquilo que você via na faculdade. E bem na época eu estava fazendo uma disciplina sobre educação infantil e tudo estava muito, muito ligado. Era muito bacana! Por que essa experiência me ajudou a construir muito do que eu sou hoje, o meu olhar diferenciado pra criança [...] (Laura, Túnel do tempo).
\end{abstract}

Dois anos após iniciar essa trajetória profissional, Laura foi convocada para assumir o concurso público da SEDF. Colocou que vislumbrou, naquele momento, a oportunidade de prosseguir em seus estudos, de realizar o mestrado, o que projetava ainda na graduação. A diferença salarial era pouca e não tinha noção da estabilidade. A coordenadora pedagógica da instituição perguntou se ela queria mesmo sair, ir para o ensino público. Ela the respondeu: "Eu vou, se eu não gostar, eu saio. A minha vontade era continuar na escola particular que eu estava. [...] Se alguém me falasse: não vai pra Secretaria de Educação, eu não tinha ido.” (Laura, Entrevista II).

Ao ingressar na SEDF foi para uma coordenação regional de ensino muito distante de sua residência, de classe econômica baixa, e assumiu uma primeira série (ensino fundamental de oito anos). A respeito desse momento, falou de modo expressivo: “[...] sair dali, quando eu passei na Secretaria de Educação, [...] foi um sofrimento, um sofrimento! Eu falava: como eu larguei aquela escola pra vir pra cá? Pra mim foi assim... [...]” (Laura, Entrevista I). Atrelado a essas colocações, afirmou:

No começo do ano foi uma catástrofe! A primeira turma na Secretaria de Educação, que foi de alfabetização, o meu primeiro ano na escola pública. Então, foi aquela bagunça! Porque você saía de uma escola particular [...], você via os alunos de cinco anos indo pra turma de seis anos quase alfabetizados. E aí, de repente você entra em outra realidade, onde muitos alunos não conseguem abrir o caderno. Os alunos estavam indo pra escola pela primeira vez. Eu me lembro do carnaval, você vai produzir um texto coletivo, o menino começou numa folha, e foi, e foi, e foi... chegou ao final, ele me perguntou o que ia fazer agora. Então, foi uma experiência 
que... eu falei: meu Deus, vou ter que aprender a fazer isso! Porque, como é que vai ser isso? [...] Então, quando eu entrei, que eu vi aquela sala de aula, aquela outra realidade, eu não tinha me preparado pra outra coisa. (Laura, Túnel do tempo).

Percebemos nesses relatos da professora que houve um impacto subjetivo significativo com a mudança que Laura sofreu entre o ensino privado e o público. Hipotetizamos que antes havia uma produção subjetiva relacionada à conquista de uma profissão, à satisfação pessoal de ter ingressado no mercado de trabalho, bem como processos subjetivos que associavam a docência à expressão criativa no trabalho pedagógico. Esse impacto, por sua vez, pode ter lhe gerado processos simbólicos e emocionais relacionados à insegurança diante das novidades, descrença em relação aos conhecimentos teóricos e práticos adquiridos em sua formação docente e sua atuação profissional.

Ainda assim, Laura mobilizou-se, colocou-se na posição de aprendiz: "vou ter que aprender isso!", como registrou. Entendemos que a professora expressou sua condição de sujeito em sua prática profissional, mesmo diante de outra realidade educativa que lhe oportunizava aquelas produções subjetivas que causavam insegurança. Ela, então, buscou espaços de formação que lhe auxiliassem nesse momento:

\begin{abstract}
Então, eu falei: vou ter que aprender! Infelizmente a faculdade não te dá esse suporte, ela te dá uma parte teórica que é muito importante, mas quando você chega na prática, é um choque! [...] Aí, foi a secretaria de educação que me deu a mão, a EAPE (Escola de Aperfeiçoamento dos Profissionais da Educação). Fui atrás de cursos de aperfeiçoamento. No final do ano, foi uma vitória de um tamanho enorme... Eu olhava pra aquelas crianças e pensava: gente, o que eu estou fazendo aqui? O que é isso? Que universo é esse? (Laura, Túnel do tempo).
\end{abstract}

Interpretamos, nessa situação, que Laura demonstrou essa possibilidade de gerar alternativas próprias, o que certamente estava relacionado a processos de reconfiguração subjetiva em torno de sua atuação profissional. Frente a sua conclusão de que a graduação não lhe oferecia o suporte necessário para o seu trabalho pedagógico naquela realidade educativa, ela recorreu à formação em serviço. Aspecto esse que converge para a nossa construção de que havia na professora a expressão da criatividade em sua dimensão funcional, um funcionamento psicológico criativo.

De acordo com ela, nesse período fez um curso que lhe deu conhecimentos relevantes para sua reorganização do trabalho pedagógico: "Fiz um curso na alfabetização, o PROFA ${ }^{10}$ [...]. Foi um trabalho maravilhoso, muito bom, muito sofrido, muito sofrido, mas foi um trabalho muito gostoso." (Laura, Túnel do tempo). No conjunto das informações essas frases nos possibilitaram compreender o papel dos conhecimentos para a expressão criativa da

\footnotetext{
${ }^{10}$ Programa de Formação de Professores Alfabetizadores, oferecido pelo Ministério da Educação.
} 
professora, o seu novo encontro com a docência. Esses conhecimentos foram subjetivados naquele espaço de formação e que, por sua relação com os interesses específicos de Laura, oportunizaram essa reorganização do trabalho pedagógico e, possivelmente, a criatividade da professora no trabalho desenvolvido na alfabetização.

Consideramos que os conhecimentos a que teve acesso naquele período estavam relacionados ao forte interesse de Laura por compreender o processo de alfabetização e as necessidades pedagógicas que se formavam nas relações com seus alunos, como é possível perceber no trecho a seguir. Foram conhecimentos subjetivados pelo viés do expressivo interesse da professora em colaborar para os processos de aprendizagem e desenvolvimento de seus estudantes, a partir das demandas identificadas por ela nas relações com seus alunos.

Laura comentou que a maioria dos estudantes ingressou no sistema de ensino na primeira série. Ao final do ano, todos os alunos estavam alfabetizados, mesmo uma aluna que entrou em setembro, o que nos permitiu entender o papel desses conhecimentos para o trabalho pedagógico de Laura. Registrou: “[...] eu massacrei os meninos no começo, no sentido... de inexperiência mesmo! (risos)" (Laura, Túnel do tempo). Acrescentou:

O grupo me acompanhou naquele desespero naquela situação e acompanhou minha evolução. [...] Tem aquela coisa, de paixão à primeira vista, aí você chega, quer fazer. O outro chega assim: está querendo fazer, o outro grupo vê o seu desespero, sua angústia. Aquela equipe (de direção) que olhava de forma diferenciada. Eu sentia isso! Na minha sala de aula, às vezes eu tinha um problema com um aluno, com alguma dificuldade, se eu levasse lá (direção), parecia que era mais agilizado. [...] por que eu estava desesperada por aquilo ali, estava me mobilizando. (Laura, Túnel do tempo, grifo nosso).

Com base nesse relato e nas demais construções, hipotetizamos que houve um movimento subjetivo gerado pela mudança da instituição privada para o ensino público. Participaram desse movimento os impactos subjetivos gerados a partir da percepção da professora acerca das diferenças significativas entre tais realidades educativas; os sentidos subjetivos vinculados ao exercício da condição de sujeito; a crença no papel ativo que possuía diante da vida, que se mostrou no seu posicionamento como aprendiz; a subjetivação dos conhecimentos a que teve acesso; bem como as produções subjetivas associadas ao compromisso profissional de Laura.

Compreendemos que esse movimento subjetivo e os processos de configuração subjetiva decorrentes desse momento participaram do desenvolvimento da criatividade da professora em seu trabalho pedagógico. Nesse processo, constituíram-se a autoria e o protagonismo de Laura em atuação profissional, a partir das produções subjetivas decorrentes dessas experiências profissionais iniciais, as quais podem ter favorecido essa condição de 
sujeito em suas práticas docentes, a satisfação pessoal de produzir o seu próprio trabalho pedagógico.

Além disso, consideramos que os conhecimentos adquiridos nesse período podem ter viabilizado a subjetivação da formação em serviço como o meio para acesso a conhecimentos pedagógicos específicos, os quais participavam de sua expressão criativa. Laura afirmou: "Nos meus primeiros quatro, até cinco anos, todo ano eu fazia um curso de formação, de 360 horas. Passava o ano fazendo curso. De lá pra cá, com a ida do meu esposo (para outro Estado), eu não consegui conciliar.” (Laura, Entrevista I, inclusão da autora). Justificou que essa mudança e a chegada dos dois filhos caçulas dificultaram a organização do seu tempo.

Enfatizou que gostava dos cursos da EAPE: "Eu amava! Fiz um de alfabetização, o PROFA. Fiz a arte de contar história, tudo de bom! Fiz a alfabetização no ensino fundamental de nove anos, e alguns outros, mas... parei." (Laura, Entrevista I). No período da pesquisa, Laura estava realizando um curso de formação em serviço acerca da educação infantil, promovido por sua coordenação regional de ensino, e havia iniciado, naquele ano, um curso de especialização também a respeito dessa etapa.

No curso da pesquisa, entendemos que tais conhecimentos sobre como contar histórias, alfabetização e educação infantil foram mobilizados no curso do trabalho pedagógico criativo de Laura. Isso porque presenciamos muitas narrativas, algumas com finalidades educativas, outras, para fruição e o estudo de letras do alfabeto a partir de palavras articuladas aos temas em pauta. Enfim, consideramos que havia uma intencionalidade pedagógica nas ações educativas desenvolvidas, as quais demonstraram o entendimento de uma especificidade pedagógica para a primeira etapa da educação básica.

As informações, ao longo da pesquisa, sustentaram a compreensão de que na criatividade de Laura no trabalho pedagógico participavam os conhecimentos subjetivados ao longo dos processos de formação em serviço, os quais se vinculavam às áreas de interesse da professora, no caso, a educação infantil. Os conhecimentos adquiridos, no decorrer de sua formação profissional, ofereceram a Laura os meios necessários para que ela fosse autora de sua prática educativa e, nesse processo, ampliasse as possibilidades de movimento de sua subjetividade individual.

Por outro lado, interpretamos que a criatividade de Laura no trabalho pedagógico gerava processos subjetivos que implicavam o seu interesse pela docência, sua realização profissional. Em outras palavras, as produções subjetivas decorrentes do processo de 


\section{elaboração pessoal e realização de suas próprias atividades educativas oportunizavam um movimento subjetivo que favorecia a constituição de motivos para sua atuação}

docente. Essa construção pode ser exemplificada pela situação em que a professora tratou a respeito de sua primeira turma de educação infantil na rede pública:

[...] Na época (2006), eu e duas colegas desenvolvemos um projeto [...], eu peguei uma turma de educação infantil. Até então, minha cabeça era de escola particular. Aí, foi nesse período que eu comecei a aceitar minha realidade de escola pública, sabendo que eu podia aplicar aquilo que eu tinha aprendido, também, na escola pública. [...] Quando eu fui pra educação infantil, eu me senti muito bem. Porque não era só coisa de sonhos a educação infantil, dava pra trazer. Lógico, com uma série de dificuldades, mas dava pra trazer aquela realidade também pra minha escola pública. Nós fizemos um trabalho MUITO bacana, nós participamos de um prêmio do MEC (Ministério da Educação), a gente conseguiu um prêmio da Secretaria de Educação, conseguimos ganhar esse prêmio interno que era de projetos na área de educação infantil. Eu e mais duas colegas, nós juntamos. [...] Uma do primeiro período, outra do segundo e uma do terceiro. O projeto se chamava: Sentindo as artes. A arte misturada com os sentidos. Muito bacana! Muita produção, muito rico o trabalho! [...] (Laura, Duas grandes premiações, inclusão da autora, grifo nosso).

O desenvolvimento do projeto citado, nessa situação, também proporcionou a Laura a constituição de sentidos subjetivos relacionados à crença na rede pública de ensino, à esperança de que poderia realizar um trabalho pedagógico segundo os seus objetivos de aprendizagem, ao prazer de atuar nessa outra realidade educativa. Compreendemos que essas produções subjetivas que lhe oportunizaram o reencontro com as instituições públicas de ensino, a aceitação das diferenças que tinha encontrado entre os dois contextos, privado e público.

Nessa perspectiva, consideramos que, no curso da realização do projeto citado, houve um processo de mudanças significativas nos núcleos subjetivos que integravam o seu trabalho pedagógico. Para Geandra Santos (2010, p. 16), essas mudanças representam uma “[...] produção alternativa de sentidos subjetivos, favoráveis à relação e responsabilização com os alunos", a qual se torna "significativa somente se for constituída por uma organização subjetiva com capacidade generativa e pelo exercício expressivo da condição de sujeito.” (SANTOS, G., 2010, p. 16). No caso de Laura, houve a produção de novos sentidos subjetivos relacionados à rede pública de ensino, os quais se vinculavam a sua expressão criativa e ao exercício da condição de sujeito em seu trabalho pedagógico, sua autoria e protagonismo nas escolhas e produções educativas.

A partir desse projeto, Laura modificou sua forma de entender a rede pública de ensino. Embora reconhecesse as diferenças e limitações que o contexto oferecia, percebeu que poderia se realizar profissionalmente, produzir novidades com valor para o processo de aprendizagem e desenvolvimento dos alunos e mais, organizar o seu próprio trabalho 
pedagógico. Interpretamos que, para tanto, colaboraram as trocas, a parceria que Laura encontrou junto às duas professoras da educação infantil. Segundo o relato, as três planejavam as atividades educativas, realizavam as pesquisas acerca dos artistas e dos materiais que poderiam ser utilizados pelos alunos para as produções artísticas. Ao falar a respeito de tais professoras, afirmou:

Foi um trabalho tão conjunto, tão conjunto, de troca de ideias! Éramos três (professoras, de três turmas diferentes), então, a gente falava: essa semana, vamos produzir com argila? Quem foi o artista que trabalhou argila? Levávamos pra sala ilustrações, vídeos de como as pessoas faziam vaso de barro [...] Foi muito bacana o fato de ter sido conjunto [...], foi um trabalho único pensado por três cabeças. Foi muito rico, porque a produção que eu fazia na minha sala era vitral, era argila, era pintura em tela, era trabalho com mosaico, mas cada um colocou um olhar diferente, cada turma fez do seu jeito. Quando nós fizemos a exposição, ficou uma coisa assim: dos sonhos! [...] (Laura, Duas grandes premiações)

Entendemos que, a relação com essas professoras durante a realização do projeto, pode ter favorecido a constituição de sentidos subjetivos vinculados ao apoio e à segurança emocional quanto à possibilidade de expressão criativa. Essas produções subjetivas se relacionam à afirmação de Mitjáns Martínez (2012b, p. 89), para a autora, na ação criativa, podem ser atualizadas configurações subjetivas:

[...] constituídas na sua história de vida e se produzem sentidos subjetivos diversos, dos quais participam, também, sentidos subjetivos e significados constituintes da subjetividade social, isto é, do espaço social no qual o sujeito realiza sua ação.

Naquele espaço educativo, o outro social, representando pelas duas professoras, se converteu em uma fonte de produção subjetiva, capaz de favorecer o interesse de Laura pela docência, pela rede pública de ensino e criatividade no trabalho pedagógico. Essa construção evidencia "[...] o outro como um outro dialógico que, em sua condição de interlocutor ativo, participa da geração do espaço social em que se define a ação criativa, da qual o outro pode participar como incentivador e estimulador [...]” (MITJÁNS MARTÍNEZ, 2004, p. 87) e, mais, "[...] pode potencializar o desenvolvimento de recursos subjetivos associados à criatividade.”, como afirma Mitjáns Martínez (2004, p. 87).

A relação com elas e o desenvolvimento desse projeto proporcionaram, assim, a constituição de sentidos subjetivos que, conforme define González Rey (2004b, p. 18), tornaram-se uma unidade subjetiva de desenvolvimento. Ou seja, produções subjetivas “ “...] com a capacidade de integrar e estimular um conjunto de aquisições do desenvolvimento em determinados momentos". Tais processos subjetivos, possivelmente, participaram da criatividade de Laura no trabalho pedagógico e lhe geraram o desenvolvimento de recursos subjetivos associados à sua autoconfiança, à flexibilidade e à crença em sua atuação 
profissional. Isso porque, mesmo frente à ausência dessas parcerias, a professora mantinha o seu trabalho pedagógico criativo, voltava-se para a produção de novidades com valor para o processo de aprendizagem dos alunos. E nesse processo criativo, atualizava os principais núcleos subjetivos que integravam sua criatividade no campo profissional.

A professora, ao fazer referências ao contexto educacional que vivia no período da pesquisa, afirmou:

Tenho a sensação de está solitária ali. Tem uma série de colegas que tem uma visão diferenciada. E muito diferenciado o grupo da manhã e da tarde, mas essa é uma realidade que a gente vive em toda escola, infelizmente. Parece que cria até certa rixa. Tem um pessoal da tarde que tem a visão um pouco mais aberta. [...] Só que... Ainda não consegui parceiros, como essas parceiras que consegui (projeto de arte). (Laura, Duas grandes premiações)

Ao ser questionada se isso a desanimava no cotidiano educativo, respondeu que não: “[...] faz falta, eu tenho vontade, mas não me desanima. Você tenta fazer ali no seu espaço, mas com certeza ia ser mais rico quando você fizesse no coletivo, sem dúvida nenhuma.[...]" (Laura, Duas grandes premiações). Essas informações nos permitiram compreender o desenvolvimento daqueles recursos subjetivos, o qual se relaciona aos processos subjetivos decorrentes da elaboração e realização desse projeto criativo e que provocaram mudanças nos núcleos subjetivos vinculados ao ser professora, ao seu interesse pela docência e pelo trabalho pedagógico. Ao escrever acerca do sentido de ser professora, Laura acrescentou:

É possível que, se voltássemos no tempo e pudéssemos zerar as experiências já vividas, porém, carregando comigo a maturidade que tenho, fizesse a escolha por outra profissão. Hoje, porém, exatamente por já ter vivido experiências tão significativas (e outras, não) na minha área de atuação, não me vejo fazendo nada mais ou menos que SER PROFESSORA, e isso por uma série de fatores:

- Sou feliz onde estou.

- Em termos práticos, concilio com tranquilidade, a minha profissão e os meus afazeres de mãe.

- Não me vejo reiniciando a construção de conhecimentos em outra área de estudo/atuação. [...]

Porém, por gostar e comprometer-me com a minha profissão, sinto-me, atualmente, desafiada a aprofundar conhecimentos na área, com o intuito de aperfeiçoar minha prática pedagógica. (Laura, Redação II).

Com esse trecho podemos exemplificar o forte significado das experiências profissionais para Laura, que podem ter colaborado para mudanças subjetivas, que ela chama de "maturidade". Interpretamos que esses processos de movimento, de produções subjetivas que se integraram e atualizaram os núcleos subjetivos que participam de seu trabalho pedagógico, certamente, foram beneficiados pelos processos simbólicos e emocionais decorrentes de sua expressão criativa. E mais, foi favorecido pela subjetivação de conhecimentos específicos no seu campo profissional. 
Nesse processo de mudanças subjetivas, compreendemos que ocorreu um desenvolvimento subjetivo em Laura, o que foi gerado pelos processos simbólicos e emocionais decorrentes de sua criatividade no trabalho pedagógico. Para González Rey (2007b, p. 138):

Percebemos o desenvolvimento tanto na possibilidade de gerar novos repertórios de
expressão de uma configuração subjetiva, que podem representar momentos de
novos sentidos subjetivos que se integram a essa configuração, como nos momentos
de reorganização e ruptura de certos sistemas de configurações subjetivas em face da
emergência de outros novos.

No caso de Laura, consideramos que esse desenvolvimento subjetivo foi caracterizado por uma produção subjetiva alternativa quanto à docência e a rede pública de ensino, as quais promoveram uma reorganização subjetiva e processos de (re) configuração subjetiva em torno da profissão e do trabalho pedagógico. Houve, ainda, a constituição de recursos subjetivos que passaram a integrar sua ação educativa e sua criatividade no campo profissional e mais, produções subjetivas que implicaram sua autoria e protagonismo no trabalho pedagógico.

Para além do trabalho pedagógico, hipotetizamos que, no caso de Laura, esse desenvolvimento subjetivo integrou outros núcleos subjetivos, como: sua autovaloração, os processos subjetivos vinculados ao bem-estar emocional, a sua satisfação e realização pessoal, a sua autoavaliação positiva, como discutimos ao tratar de sua subjetividade individual, assim como a atualização de processos subjetivos relacionados à sua exigência consigo mesma, à satisfação decorrente do reconhecimento social, ao seu intuito de superação. Inferimos, portanto, que as produções subjetivas que se constituíram com base em sua criatividade nas práticas educativas favoreceram a emergência e atualização de sentidos subjetivos associados a outros campos que não apenas o profissional e, também, o exercício da condição de sujeito.

Interpretamos, então, que havia inter-relações entre a criatividade no trabalho pedagógico e o movimento da subjetividade individual da professora. Nesse caso específico, um desenvolvimento subjetivo que foi favorecido pelos processos subjetivos que se constituíram a partir de sua expressão criativa no trabalho pedagógico. De forma que, ao mesmo tempo em que a criatividade depende do posicionamento como sujeito de sua prática docente, dos núcleos subjetivos de sua subjetividade individual e da subjetividade social da instituição, essa criatividade possibilitou produções subjetivas que, no caso, movimentaram Laura subjetivamente. Os processos subjetivos que se constituíram no trabalho pedagógico criativo atualizaram os principais núcleos subjetivos da professora. 


\subsubsection{Considerações parciais acerca do caso da professora Laura}

No caso de Laura, compreendemos que o seu trabalho pedagógico caracterizava-se como uma organização sistêmica e criativa, no qual destacamos sua criatividade: na organização dos conteúdos de ensino; na formulação dos objetivos de aprendizagem; na elaboração de atividades educativas, de estratégias e métodos de ensino; e na constituição de um clima comunicativo-emocional diferenciado. No processo construtivo-interpretativo, consideramos que, dentre os processos subjetivos que participavam da criatividade no trabalho pedagógico desta professora, estavam:

a) a forma como subjetivou a função social da educação infantil, como um atendimento com propósitos educativos específicos, adequados às crianças de quatro e cinco anos de idade;

b) a subjetivação do papel do professor como responsável por oportunizar situações e recursos educativos que facilitassem a aprendizagem de seus alunos;

c) a forma como a aprendizagem foi subjetivada: como esse processo de construção de conhecimentos, em que as crianças tinham um papel ativo, participavam com sua singularidade, com as formas específicas de funcionamento;

d) a subjetivação do aluno como criança que merecia ser respeitada e considerada na organização do trabalho pedagógico.

No trabalho pedagógico criativo de Laura participava, também, a imaginação como recurso subjetivo, que permeava o processo de elaboração e produção das atividades educativas que ela oferecia aos seus alunos. Os processos imaginativos eram mobilizados em sua criatividade no trabalho pedagógico, antecediam sua prática docente.

Além disso, compreendemos que os sistemas relacionais que se formaram entre Laura e os estudantes favoreciam a constituição do aluno como um outro social que participava de sua criatividade no trabalho pedagógico. Para favorecer o seu processo de aprendizagem, de acordo com a educação infantil, a professora mobilizava-se para a produção de novidades com valor para esse processo. As especificidades da infância, reconhecidas em seus estudantes, geram desafios e necessidades pedagógicas que implicavam sua expressão criativa no trabalho pedagógico.

Tais construções relacionam-se à intencionalidade pedagógica que permeava suas práticas educativas, a sua autoria e protagonismo no trabalho pedagógico, isto é, a sua condição de sujeito em sua prática profissional. Esses aspectos estão atrelados aos núcleos 
subjetivos que integravam a criatividade de Laura no trabalho pedagógico. Dentre eles estavam aqueles vinculados à: família, exigência consigo mesma, autovaloração e profissão - ser professora. Esse último considerado como tendência orientadora de sua personalidade.

No curso da pesquisa, entendemos, ainda, que a expressão criativa de Laura em seu trabalho pedagógico se relacionava ao seu funcionamento psicológico criativo, à geração de alternativas singulares e autônomas. A professora tinha esse posicionamento ativo diante da vida, enfrentava as situações pessoalmente significativas. E no trabalho pedagógico, empenhava-se em favorecer a aprendizagem de seus estudantes, em gerar alternativas singulares e autônomas de ação, o que envolvia a organização de materiais e recursos pedagógicos e a constituição de um clima comunicativo-emocional caracterizado pela harmonia entre professora e alunos.

Hipotetizamos, assim, que a criatividade no trabalho pedagógico dessa professora decorria dessa forma de funcionamento psicológico, caracterizada por sua criatividade. E estava relacionada à sua subjetividade individual, tanto a expressão de sua condição de sujeito, como às produções subjetivas que se organizavam em núcleos subjetivos específicos, que integravam sua expressão criativa.

Por outro lado, compreendemos que os processos subjetivos que se constituíam em seu trabalho pedagógico criativo tinham valor, também, para a própria professora, para a emergência de sentidos subjetivos que integravam os seus principais núcleos subjetivos. E, em algumas situações, como a apresentada antes, promoviam processos de mudanças subjetivas significativas, movimentando núcleos subjetivos que participavam do seu trabalho pedagógico, da sua autovaloração e exigência consigo mesma, caracterizando um desenvolvimento subjetivo beneficiado por essa expressão criativa. 


\section{ANÁLISE INTEGRATIVA DOS CASOS, PRODUÇÃO TEÓRICA ACERCA DA CRIATIVIDADE NO TRABALHO PEDAGÓGICO DO PROFESSOR E O MOVIMENTO EM SUA SUBJETIVIDADE}

A construção das informações a respeito dos casos de Ananda, Júlia e Laura, apresentados, anteriormente, nos possibilita tecer algumas considerações sobre a contribuição teórica da pesquisa por ora desenvolvida. Nesse estudo, o foco centrou-se na compreensão de processos subjetivos que configuram a criatividade no trabalho pedagógico do professor e suas inter-relações com o movimento em sua subjetividade.

Para alcançar esse objetivo, propomos, no momento, evidenciar as construções realizadas a respeito de cinco eixos de análise, que respondem aos propósitos deste estudo, quais sejam: a) os processos subjetivos que participam da criatividade no trabalho pedagógico do professor; b) o aluno nessa expressão criativa; c) o professor como sujeito de sua prática profissional; d) os principais núcleos subjetivos associados ao trabalho pedagógico criativo; e) os movimentos subjetivos relacionados à criatividade no trabalho pedagógico.

Como dito antes, entendemos que a própria complexidade da criatividade, segundo a perspectiva teórica adotada, nos conduz às articulações entre tais eixos e requerem, de forma constante, referências a aspectos que se integram na dinâmica subjetiva. Ainda assim, assumimos essa proposta de construção em pontos centrais por considerarmos que a apresentação gradativa das informações viabiliza, com maior solidez, o encontro com o objetivo geral desta pesquisa.

$\mathrm{Na}$ perspectiva teórica que assumimos, a criatividade é um processo complexo da subjetividade humana (MITJÁNS MARTÍNEZ, 2004, 2008a), que ressalta as particularidades constitutivas dessa expressão criativa, da qual participam tanto elementos da subjetividade individual, como da subjetividade social. Nos casos apresentados, entendemos que essas particularidades imprimiram marcas específicas que caracterizam de diversas maneiras a criatividade no trabalho pedagógico do professor, gerando especificidades que outorgam como legítimos os critérios de novidade e valor das ações educativas desenvolvidas com os seus alunos. Cada docente demonstrou, assim, uma forma personalizada de expressão criativa.

Para Ananda, as produções subjetivas decorrentes das relações com os estudantes eram relevantes em sua organização subjetiva, ela almejava um relacionamento amistoso, permeado pelo interesse, curiosidade e implicação dos alunos nas atividades realizadas. Interpretamos 
que isso colaborava para a mobilização da professora na constituição de relações personalizadas com cada um deles e de um clima comunicativo-emocional que favorecesse a aprendizagem e desenvolvimento dos estudantes. Voltava-se para uma organização do processo de ensino-aprendizagem que valorizasse o pensamento, reflexão e autoria dos alunos. Ampliava o trabalho pedagógico para além dos objetivos de aprendizagem prescritos no currículo da instituição e para tanto, propunha estratégias e métodos de ensino articulados aos focos de seu interesse.

Nos casos das professoras Júlia e Laura a expressão criativa no trabalho pedagógico possuía outras "marcas". A primeira se empenhou na construção de uma metodologia de ensino própria, que proporcionasse a concretização da alfabetização e o acesso aos conhecimentos culturais. Laura, por sua vez, possuía uma organização do trabalho pedagógico direcionada para as especificidades da infância e ao desenvolvimento da autonomia dos estudantes. Nessas duas professoras, os relacionamentos com os estudantes também eram fonte de produções subjetivas e participavam de sua criatividade nas ações educativas empreendidas. Entretanto, de maneira significativa, estavam os processos simbólicos e emocionais que se constituíam no curso da elaboração e produção do trabalho pedagógico criativo, o que se mostrou de modo mais marcante para a expressão criativa de Júlia e Laura.

Esses processos simbólicos e emocionais que se constituíam nas ações educativas formuladas e realizadas pelas professoras organizaram-se em diversas produções subjetivas. Dentre esses, a nossa pesquisa evidenciou as formas particulares com que elas subjetivaram o papel do professor, o que, como afirma González Rey (2011c), não diz respeito apenas a processos simbólicos relacionados ao ser professor, envolve a emocionalidade gerada no curso do trabalho pedagógico criativo.

Para Ananda, cabia a ela pensar e estruturar o trabalho pedagógico; havia sentidos subjetivos relacionados à responsabilidade e ao seu compromisso profissional. No caso de Júlia, interpretamos que o professor era visto como responsável por ampliar as oportunidades de aprendizagem dos alunos, e, com isso, colaborar para a função social da educação, segundo sua maneira de subjetivar essa função. Para Laura, o professor era visto como o responsável por oportunizar situações e recursos educativos que facilitassem a aprendizagem de seus estudantes.

Cada uma, à sua maneira, personalizou sua forma de compreender a atuação docente, sendo que, nas três, existiam processos subjetivos vinculados a sua responsabilidade frente ao trabalho pedagógico, o que caracterizava a subjetivação do papel do professor. 
Esses sentidos subjetivos, por sua vez, impeliam essa participação ativa das professoras, sua iniciativa na organização do trabalho pedagógico e a produção e articulação das atividades educativas com os objetivos de aprendizagem propostos.

Essas produções subjetivas articulavam-se aos processos de subjetivação a respeito da função social da educação, os quais implicavam a ação intencional das três professoras para a produção de novidades com valor para a aprendizagem dos estudantes. Interpretamos que, para Ananda, era importante que o seu trabalho pedagógico favorecesse uma formação humana. Para Júlia, sua ação educativa poderia auxiliar os alunos a ter acesso a uma gama de conhecimentos que lhes daria a oportunidade de mudanças sociais. Já para Laura, a educação infantil possuía uma especificidade pedagógica própria, o que incluía conhecimentos de mundo, desenvolvimento da autonomia e o brincar. Cada uma delas subjetivou essa função social, mas em todas consideramos um direcionamento à formação integral dos alunos, o que abrangia o contato com diferentes áreas do conhecimento. Aspecto esse que se vinculava a forma como subjetivaram o aluno.

No curso da pesquisa, compreendemos que, para Ananda, os estudantes eram vistos como crianças, dotadas de sentimentos, liberdade, encantamentos, potencial para a construção de conhecimentos. Em Júlia, os alunos eram considerados como seres sociais, que participavam ativamente do seu processo de aprendizagem. Para Laura, eram crianças que mereciam ser respeitadas e consideradas na organização do trabalho pedagógico. Em todas elas, os processos de subjetivação em relação aos estudantes envolviam sua participação ativa no processo de compreensão e construção dos conhecimentos e a valorização de suas ideias e colocações. Na sala de aula da professora Ananda, por exemplo, as atividades educativas oferecidas aos alunos tinham a reflexão, a autoria e produção de ideias como elementos marcantes, que permeavam as diferentes tarefas realizadas. A fim de contemplar esses alunos ativos e participativos, as professoras se empenhavam em propor atividades novas e com valor para os processos de aprendizagem e desenvolvimento.

Poderiam, assim, promover situações pedagógicas que favorecessem o processo de aprendizagem, segundo as peculiaridades com que subjetivaram esse processo. No caso de Ananda, entendemos que ela subjetivou a aprendizagem como uma construção que estava além da reprodução de conteúdos, abrangia a compreensão do assunto em pauta e, de certa forma, uma personalização do aprendido, o que se dava por meio das produções de ideias a partir dos assuntos estudados. Nas ações educativas de Júlia, a aprendizagem representava essa possibilidade de compreender os conteúdos trabalhados. Para Laura, esse era um 
processo de construção, em que as crianças tinham um papel ativo, participavam com sua singularidade, com as formas específicas de funcionamento. Nos três casos, a subjetivação da aprendizagem escolar estava associada à compreensão e a elaboração pessoal a partir do aprendido, o que requeria a participação dos alunos na realização das atividades educativas e do professor como agente favorecedor do acesso aos conhecimentos.

Para tanto, as professoras buscavam conhecimentos pedagógicos específicos, os quais poderiam lhes auxiliar na organização de um trabalho pedagógico que atendesse às formas peculiares com que subjetivaram o papel do professor, a função social da educação, o aluno e a aprendizagem. Esses conhecimentos se articulavam às necessidades pedagógicas que se constituam nas relações entre as professoras e os estudantes, no curso das ações empreendidas na dinâmica escolar. Entendemos, então, que os conhecimentos mobilizados na expressão criativa das três professoras relacionavam-se, de maneira significativa, aos processos de formação em serviço, os quais representavam a possibilidade de ampliação de um repertório pedagógico que lhes permitia enfrentar os desafios educativos que se formavam no cotidiano escolar.

Tais conhecimentos participavam da criatividade de Ananda, Júlia e Laura no trabalho pedagógico, integravam as escolhas, a elaboração e produção das atividades realizadas pelos alunos, enfim, a própria singularidade das expressões criativas de cada uma delas. E mais, vinculavam-se aos campos de interesses das professoras, que envolviam áreas para além do campo profissional. Em Ananda, por exemplo, havia o interesse pela filosofia e as artes, interesse que se apresentava de modo geral em sua vida. Para Júlia, sua prática profissional lhe solicitava conhecimentos em alfabetização, mas interessava-se por línguas estrangeiras e atividades físicas. Laura buscava conhecimentos no campo da educação infantil e da contação de histórias, que valorizava, também, em sua família. Em todas elas, esses interesses particulares repercutiam em sua expressão criativa nas práticas pedagógicas que elaboravam para os seus alunos, tais conhecimentos eram subjetivados e modificados na dinâmica educativa em função dos propósitos almejados.

Nessa direção, consideramos que nem todo processo de formação em serviço gera impactos na atuação docente e na criatividade no trabalho pedagógico, é necessária a relação com as demandas educativas advindas das experiências docentes, das relações entre professor e alunos; a articulação com os interesses de cada docente, o que contempla o campo profissional e pessoal; bem como a subjetivação, a personalização do aprendido. 
Esses aspectos evidenciam a relevância dos processos de formação docente e sua articulação com a realidade vivida pelos professores.

Compreendemos que aí reside a importância dos conhecimentos para a criatividade no trabalho pedagógico. Em estudos anteriores, Ussene (2006), Alencar e Fleith (2003) e De La Torre (2005) ressaltaram o papel da formação docente para o desenvolvimento da criatividade dos estudantes, isto é, uma formação que favorecesse aos professores meios para desenvolver a expressão criativa dos alunos. Entendemos que, concomitante a esse intuito, faz-se necessário que os espaços de formação docente favoreçam a constituição do professor como sujeito de sua prática profissional, sua produção das práticas educativas. E despertem, ainda, o interesse por diferentes possibilidades de aprendizagem, por diversos campos do conhecimento e lhes favoreçam a personalização do aprendido, utilizando-o em diferentes situações educativas.

Consideramos que os processos de formação em serviço se beneficiaram com as relações entre as professoras e os seus alunos, com as demandas e desafios educativos oferecidos pelos estudantes. Nessas relações, constituíam-se necessidades pedagógicas que implicavam as docentes para a mobilização do aprendido em termos pedagógicos, a busca de outros conhecimentos, bem como a produção de novidades com valor para os processos de aprendizagem e desenvolvimento dos estudantes.

No intuito de colaborar para esses processos, Ananda, Júlia e Laura empenhavam-se em organizar um trabalho pedagógico que possibilitasse avanços na construção de conhecimentos, que lhes permitisse alcançar os objetivos de aprendizagem propostos para cada turma. Júlia, por exemplo, em sua primeira turma como professora (concursada da SEDF) teve estudantes em níveis distintos do processo de alfabetização e mais uma aluna com deficiência visual. Interpretamos que, pautada na relação personalizada que possuía com eles, nas particularidades que apresentavam no processo educativo, a professora mobilizou-se para compreender a alfabetização e para organizar um trabalho pedagógico que contemplasse as especificidades que indicavam. Com isso, produziu novidades com valor para a aprendizagem e desenvolvimento dos estudantes.

Entendemos, assim, que o aluno pode se constituir como um outro social que participa da criatividade no trabalho pedagógico do professor, por meio dos desafios e das necessidades educativas que implicam o docente para a produção de novidades com valor para sua aprendizagem e desenvolvimento. Para tanto, faz-se relevante a formação de vínculos entre professores e alunos, os quais, por sua constituição subjetiva, podem favorecer 
a mobilização de processos e recursos subjetivos que integram essa expressão criativa. Isto é, as relações estabelecidas no contexto educativo podem se constituir como palco para a formação de motivos que, aliados a outros sentidos subjetivos e a própria organização subjetiva do docente, participam da criatividade no trabalho pedagógico.

A propósito, ressaltamos que esses motivos e necessidades educativas que podem se formar a partir das relações entre docente e alunos se vinculam a outras produções subjetivas que participam da criatividade no trabalho pedagógico do professor, outros motivos constituídos historicamente, como também, a outros processos subjetivos que configuram a sua subjetividade individual.

Reconhecemos, ainda, que essas relações entre professores e alunos nos permitem destacar a participação dos processos emocionais para a criatividade no trabalho pedagógico, a relevância de vínculos afetivos no contexto escolar. Construção essa que converge para a união dos processos simbólicos e emocionais, como explica a Teoria da Subjetividade na perspectiva Histórico-Cultural, assim como para as colocações de Mitjáns Martínez (2003a). Para a autora, a criatividade não é explicável apenas em função de operações cognitivas ou intelectuais, tendência, segundo a autora, com peso significativo dentro da psicologia da criatividade.

O nosso estudo pode contribuir, nessa perspectiva, ao evidenciar que da expressão criativa do professor no trabalho pedagógico participa a emocionalidade gerada nas relações entre ele e os estudantes. Esses processos emocionais podem ocorrer em duas direções fundamentais, quais sejam: a) na formação de vínculos afetivos que se estabelecem na dinâmica educativa, os quais comprometem o professor e implicam sua mobilização para a promoção da aprendizagem dos alunos, como podemos considerar, mais expressivamente, no caso de Ananda e Júlia; e b) como parte constitutiva dos processos que emergem na ação criativa, na integração com processos simbólicos; em outras palavras, nos processos de subjetivação, na produção de sentidos subjetivos que se formam no curso no trabalho pedagógico criativo, que atualizam os principais núcleos subjetivos que participam dessa criatividade e o interesse das professoras pela docência.

Tais direções nos aproximam das afirmações de González Rey (2011c, p. 347, tradução nossa): na subjetividade retomam-se dois temas que foram excluídos por outras perspectivas teóricas, quais sejam, a motivação humana e o caráter ativo do sujeito. Para ele:

Não se pode pensar a subjetividade humana sem destacar esses dois aspectos. Não são as práticas simbólicas em abstrato que movem as ações humanas; todo movimento humano em sua dupla condição social e individual se caracteriza por uma emocionalidade presente na ação: não há ação transformadora sem emoção. 
Consideramos que as ações criativas empreendidas pelas três participantes do estudo de casos se caracterizavam pela união de processos simbólicos e emocionais, bem como, pelo exercício da condição de sujeito em sua prática profissional. Essa condição se relacionava à intencionalidade pedagógica que permeava as práticas de ensino elaboradas e realizadas no cotidiano educativo, e que imprimiam o caráter novo e valioso às ações formuladas por Ananda, Júlia e Laura. A criatividade no trabalho pedagógico para as três professoras voltavase para a consecução de propósitos educativos que lançavam para os seus estudantes, a maneira particular como cada uma delas entendia os objetivos de aprendizagem que perpassavam o seu trabalho docente.

Além disso, compreendemos que essa condição de sujeito se revelava, ainda, nos processos de autoria e protagonismo no trabalho pedagógico de Ananda, Júlia e Laura, possibilitando às professoras produzir, elaborar, pensar sobre suas próprias atividades educativas, de acordo com a subjetivação dos propósitos educativos de cada uma delas. Essa afirmação se relaciona à colocação de Mitjáns Martínez (2008a) acerca da participação da condição de sujeito do professor para a criatividade no trabalho pedagógico. Mas avança na especificidade de que o sujeito se expressa nessa possibilidade de o professor ser o autor de suas atividades educativas, ser ele o protagonista das escolhas pedagógicas, quem de forma intencional e consciente organiza o seu trabalho pedagógico, direcionando o processo de ensino-aprendizagem segundo os propósitos educativos subjetivados ao longo de suas experiências.

Nas três professoras, o trabalho pedagógico era caracterizado por atividades personalizadas, por ações e por uma organização das práticas educativas que evidenciaram a autoria e a iniciativa na sua produção. Não se rendiam ao livro didático, tarefas xerografadas e copiadas de coleções didáticas, ao contrário, subvertiam as práticas legitimadas e aceitas no contexto escolar.

Nesse aspecto, o nosso estudo coaduna as afirmações de Távora (2010) que verificou a criatividade dos professores em momentos considerados como transgressores, que rompem com o que está estabelecido no espaço da instituição, o que compreendemos, de maneira expressiva, no caso de Júlia e Laura. No caso dessa última professora, vimos que, apesar de estar inserida em um contexto social marcado pela violência e por tratamentos agressivos entre professor e alunos, ela foi capaz de constituir em sua turma um clima comunicativoemocional caracterizado pela harmonia entre os estudantes, segurança emocional em se 
colocarem e exporem suas dúvidas e pelo respeito mútuo, o que consideramos como um aspecto de sua criatividade no trabalho pedagógico.

No processo construtivo-interpretativo, compreendemos que essa possibilidade de criatividade no trabalho pedagógico das professoras e a geração de alternativas frente às diferentes experiências relacionava-se ao funcionamento psicológico criativo que caracteriza as três professoras. Ananda, por exemplo, tinha um posicionamento ativo diante da vida, colocava-se como agente de suas escolhas e decisões, enfrentava os desafios que se constituíam em suas experiências, como a gravidez na adolescência e a segunda separação matrimonial. Além disso, tinha uma série de interesses, de campos que lhe despertavam experiências emocionais positivas, como a prática de Reike, os encontros familiares, a culinária, a arte, dentre outras. A professora Júlia, embora não tivesse a implicação em projetar suas ações e o seu futuro, mobilizava-se para gerar alternativas frente às situações vividas, produzia meios de alcançar os propósitos traçados, como o momento do vestibular. Laura, por sua vez, enfrentava de forma autônoma e personalizada as adversidades e diversas experiências que se formavam ao longo de sua vida, colocava-se diante dos imprevistos e das mudanças como responsável por gerar alternativas e encontrar as vias que lhe permitisse superar as dificuldades encontradas, como no momento em que seu esposo foi morar em outra cidade.

Tais exemplos, atrelados às demais informações advindas do processo de pesquisa acerca de diversas experiências vividas pelas professoras, nos conduziram à compreensão de que a criatividade caracterizava uma forma peculiar de funcionamento subjetivo. Ou seja, a criatividade mostrou-se em uma dimensão funcional, a qual, segundo Mitjáns Martínez (2009a, p. 35), envolve:

[...] o processo de configuração e reconfiguração da subjetividade que se expressa nas formas singulares e autônomas da ação do sujeito nos contextos sociorrelacionais nos quais está inserido. Assim, a formação de novos sentidos subjetivos, que permitem ao sujeito formas mais diversificadas e complexas de atuação ante situações pessoalmente significativas, poderia ser considerada processos criativos.

Entendemos que, nos casos de Ananda, Júlia e Laura, os processos simbólicos e emocionais que se constituíam nessas situações significativas, em especial, no campo pessoal e profissional, geravam a atualização de núcleos subjetivos que se organizavam em sua subjetividade individual e lhes proporcionava condições subjetivas de enfrentar as dificuldades vividas e gerar alternativas de ação e posicionamento próprio, viabilizando, então, o exercício da condição de sujeito, inclusive na profissão. 
Júlia, por exemplo, não percebia a pedagogia como uma escolha pessoal, que fosse de fato uma atuação profissional almejada. Entretanto, diante do desafio de ensinar e favorecer a aprendizagem de seus alunos, mobilizou-se para produzir novidades com valor para a sua aprendizagem e desenvolvimento. Laura, imersa nas fortes produções subjetivas que se constituíam no processo de mudança entre a instituição privada que lecionava e a rede pública, buscou meios para enfrentar a necessidade de alfabetizar os estudantes. No conjunto das informações construídas nos três casos, essas situações nos fizeram compreender que a dimensão instrumental da criatividade, que representa a produção de novidades com valor para a aprendizagem dos alunos, decorre de um funcionamento psicológico criativo, da dimensão funcional da criatividade.

Consideramos, assim, que esse funcionamento psicológico criativo favoreceu a criatividade no trabalho pedagógico de Ananda, Júlia e Laura. Sendo que dessa expressão criativa integravam-se alguns dos núcleos subjetivos que constituíam a subjetividade individual dessas professoras. No caso de Ananda, a construção das informações nos permitiu compreender a participação das produções subjetivas que se organizavam em torno: da autovaloração, profissão - ser professora, relação com os alunos e família. Em Júlia, tais produções se referiam: à família, ao compromisso profissional e ao trabalho pedagógico. No caso de Laura, participavam os núcleos subjetivos relacionados: à família, à exigência consigo mesma; à autovaloração e à profissão- ser professora.

Compreendemos, nessas construções, que a profissão não foi identificada em todos os casos como um núcleo subjetivo relevante para a criatividade no trabalho pedagógico e, mais, apenas em Ananda e Laura, entendemos esse núcleo subjetivo da profissão como tendência orientadora da personalidade. No caso de Júlia, as produções subjetivas que emergiam do trabalho pedagógico não configuravam a profissão - ser professora - como um núcleo subjetivo dominante em sua subjetividade individual, o que coaduna a pouca projeção quanto à sua profissão, nela não encontramos uma orientação clara em relação ao futuro profissional. Reafirmamos, assim, as colocações de González Rey (2011c, p. 349) ao tratar acerca dos processos de subjetivação. Para ele, as experiências atuais são produções sobre múltiplos processos de origem diversa que, "[...] tendo participado de uma forma ou de outra na história de vida da pessoa e de um espaço social particular, convergem numa configuração subjetiva de sua experiência atual.”.

Interpretamos que, em Júlia, os processos simbólicos e emocionais que se constituíam em torno da família e do forte compromisso profissional, articulavam-se aos sentidos 
subjetivos que se formavam a partir do trabalho pedagógico criativo, integrando essa expressão criativa. Esses aspectos apresentados em nosso estudo divergem das afirmações de Mitjáns Martínez (2008a) em relação à participação da subjetividade individual dos professores para sua criatividade no trabalho pedagógico, no que diz respeito à profissão como tendência orientadora da personalidade.

Aproximamo-nos das colocações da citada autora no que se refere a produções subjetivas relacionadas à força da individualidade, à autovaloração, como nos casos de Laura e Ananda. Em consonância com a citada autora, consideramos, também, a orientação ativa para a superação no campo profissional, o que se mostrou presente nas três professoras estudadas; assim como, a presença de processos imaginativos para a criatividade no trabalho pedagógico.

Em cada uma delas, a imaginação participava de formas diferentes de sua expressão criativa no trabalho pedagógico. Ananda e Laura utilizavam-se dos processos imaginativos como um recurso subjetivo mobilizado no momento de planejar o seu trabalho pedagógico. No caso de Júlia, especialmente, a imaginação era um recurso pedagógico mobilizado no trabalho pedagógico criativo, além de se constituir como recurso subjetivo. Essas construções convergem para as afirmações de Mitjáns Martínez (2014) que relacionam a criatividade e a imaginação.

Nesse processo imaginativo e de autoria no trabalho pedagógico, constituíam-se sentidos subjetivos que repercutiam na atualização e na movimentação dos principais núcleos subjetivos que integravam a expressão criativa das três professoras. Em Ananda, interpretamos que a criatividade no trabalho pedagógico gerava produções subjetivas vinculadas ao prazer de ensinar, ao seu bem-estar emocional, sua satisfação e realização pessoal e profissional, dentre outros. No caso de Júlia, o processo de elaborar as atividades, selecionar os materiais e produzir recursos pedagógicos e organizar sua própria metodologia de ensino lhe favoreciam sentidos subjetivos relacionados à sua satisfação profissional, ao desejo de realizar com êxito suas práticas educativas, colaborar para mudanças nas condições socioeconômicas de seus alunos e outros, que se tornavam motivos para sua permanência na docência. Para Laura, o processo criativo era fonte de sentidos subjetivos associados ao seu entusiasmo, a sua satisfação e realização profissional em atuar como professora e participar da aprendizagem dos estudantes, dentre outras produções.

Havia, portanto, uma relação recursiva entre a organização subjetiva das professoras, que geravam condições para o posicionamento ativo e criativo no trabalho 
pedagógico, e os processos subjetivos que se constituíam nas experiências pedagógicas advindas dessa criatividade no trabalho pedagógico, os quais movimentavam e atualizavam núcleos subjetivos da subjetividade individual das professoras. Nessa perspectiva, avançamos nas conclusões de Mourão (2004), que, a partir de sua pesquisa, afirmou a relação recursiva entre o sentido subjetivo da criatividade do professor e sua prática pedagógica com projetos. Mais que sentidos subjetivos relacionados à criatividade, essa expressão criativa pode favorecer processos subjetivos vinculados a outros núcleos subjetivos e ao próprio exercício da condição de sujeito na atuação profissional. No caso de Laura, por exemplo, as produções subjetivas decorrentes de sua criatividade no trabalho pedagógico abrangiam sua autovaloração e uma forte exigência consigo mesma, estavam para além da relação entre os sentidos subjetivos da criatividade e a prática com projetos. Em Júlia, os sentidos subjetivos que se constituíam no seu trabalho pedagógico criativo vinculavam-se não apenas ao trabalho pedagógico com projetos, mas à sua família, em especial, à figura paterna.

Nesse processo recursivo, vimos, no decorrer da pesquisa, a participação de produções subjetivas que se relacionavam à história de vida das professoras, às particularidades dos processos de subjetivação que ocorreram ao longo de sua formação docente, às experiências vividas antes, nos diferentes espaços sociais e educativos que atuaram, mas que envolviam também as relações atuais com os alunos, as experiências vividas na instituição em que trabalhavam no momento do estudo. Aproximamo-nos, assim, da compreensão de que a experiência atual das professoras envolve "[...] uma produção de sentidos subjetivos em que a ação é um momento da configuração subjetiva que se organiza no seu próprio curso", como afirma González Rey (2011c, p. 352), e que abrange a união inseparável da história da pessoa e os contextos de sua ação, como ele aponta.

Entendemos que essa movimentação subjetiva advinda das ações, das experiências com o trabalho pedagógico criativo, nos casos de Ananda, Júlia e Laura, desdobrou-se em processos distintos: movimento, mudanças significativas e desenvolvimento subjetivo, respectivamente. Essa construção nos permite reafirmar as colocações de Geandra Santos (2010), que, pautada na Teoria da Subjetividade na perspectiva Histórico-Cultural, compreende que a mudança subjetiva inscreve-se recursivamente na movimentação complexa constitutiva do desenvolvimento da subjetividade, de modo que nem toda mudança é motor do desenvolvimento.

No caso de Ananda, compreendemos que as produções subjetivas que se constituíam a partir do trabalho pedagógico criativo atualizavam os principais núcleos subjetivos que 
integravam essa criatividade, como dito antes. Com isso, movimentavam sua subjetividade individual, mantendo-a ativa e emocionalmente comprometida com sua prática profissional, apesar das dificuldades que encontrava, como a separação matrimonial e o salário que, para ela, não correspondia às demandas realizadas ao professor. Atribuímos essa movimentação ao próprio funcionamento psicológico criativo de Ananda, caracterizado pelos processos de (re) configuração subjetiva.

Para Júlia, sua criatividade no trabalho pedagógico gerou, em certo momento da sua vida, a possibilidade de encontro com a profissão - ser professora, sentidos subjetivos relacionados à sua satisfação e realização com a docência, bem como processos simbólicos e emocionais associados a sua autodiferenciação do modo dominante de atuação profissional que percebia na SEDF. Produções subjetivas que interpretamos como constituintes de um processo de mudanças significativas em sua subjetividade individual.

Em Laura, consideramos que o processo construtivo-interpretativo viabilizou a compreensão de que a criatividade no trabalho pedagógico proporcionou um desenvolvimento subjetivo. Isto é, as produções simbólicas e emocionais constituídas na experiência do projeto, que foi realizado com outras duas professoras em sua primeira turma de educação infantil na rede pública, permitiram a emergência de sentidos subjetivos alternativos frente ao ensino público e a constituição de recursos subjetivos associados a sua autoconfiança, à flexibilidade e à crença em sua atuação profissional. Processos subjetivos que implicaram e fortaleceram sua condição de sujeito na sua atuação profissional e repercutiram, por outro lado, para sua expressão criativa no trabalho pedagógico.

Além da reconfiguração subjetiva relacionada ao trabalho pedagógico, consideramos que, em Laura, esse desenvolvimento subjetivo favoreceu a movimentação e a emergência de sentidos subjetivos vinculados à sua autovaloração, no que se refere a sua autoimagem e autoavaliação positiva, bem como a sua exigência consigo mesma. Processos subjetivos que se ampliaram para além do campo profissional. Nesse caso, especificamente, entendemos que houve o processo que Rossato (2009, p. 181) apontou como desenvolvimento subjetivo: "mudanças subjetivas que ganham certa estabilidade, originando outras mudanças, gerando novos níveis qualitativos de organização subjetiva.".

Esses percursos distintos ressaltam as afirmações de González Rey (2012, p. 34) ao tratar a subjetividade como uma produção singular da pessoa, que possui como matéria prima sua vida social e cultural. Nessa produção não há relação direta entre o caráter objetivo de uma experiência vivida e a maneira como ela influencia o desenvolvimento psíquico. Esse 
desenvolvimento "[...] está sempre metamorfoseado por uma produção de sentidos subjetivos que se definem na configuração subjetiva da experiência vivida.”.

Em todas as situações apresentadas, de movimento, mudança ou desenvolvimento subjetivo, evidencia-se um valor da criatividade no trabalho pedagógico para o próprio professor. No estudo dos três casos, compreendemos que o valor da criatividade apresentouse em duas direções: a) para a subjetividade individual das professoras; b) para a aprendizagem e desenvolvimento dos alunos. No que se refere à aprendizagem dos estudantes, o valor estava tanto na possibilidade de gerar situações educativas favoráveis à compreensão dos assuntos em pauta, como na promoção de um trabalho pedagógico que lhes despertava o interesse pela aprendizagem e aguçava a curiosidade, mantendo-os ativos e participativos no processo de ensino-aprendizagem. Nas três turmas, observamos o entusiasmo dos alunos, sua movimentação na dinâmica educativa, o forte empenho em realizar as atividades educativas propostas pelas professoras.

Para além desses aspectos, interpretamos que o trabalho pedagógico criativo para Ananda, Júlia e Laura oportunizava a constituição de sentidos subjetivos que se integravam aos principais núcleos subjetivos que participavam dessa criatividade, proporcionando-lhes a atualização de motivos para sua atuação docente. Para Laura, por exemplo, as ações empreendidas no curso do trabalho pedagógico criativo lhe geravam sentidos subjetivos vinculados ao seu bem-estar emocional, à sua realização pessoal e profissional, mesmo que reconhecesse a desvalorização social de sua profissão. Essas considerações coadunam as afirmações de Mitjáns Martínez (2009a, p. 35) ao tratar da dimensão funcional da criatividade: “[...] nessa interpretação, não existe um valor conferido por outros, associado a um produto.”. E, mais: “[...] Aqui, o verdadeiramente definidor é o processo de novidade, de mudança, assim como a significação para o funcionamento integral da subjetividade.”.

Entendemos que esse valor da criatividade no trabalho pedagógico para as próprias professoras relacionava-se, também, à compreensão de que a motivação se atualiza no curso da criatividade no trabalho pedagógico, momentos em que se constituem processos simbólicos e emocionais que podem se organizar como outros motivos para essa expressão criativa. Construção essa que alia as produções subjetivas históricas e atuais como motivos para a expressão criativa no trabalho pedagógico.

Consideramos que no curso das ações criativas, das experiências vividas no espaço escolar, podem se formar outros motivos associadas a tais ações, o que está em consonância com as afirmações de González Rey (2007b, p. 128): “[...] a ação é fonte permanente de 
produção de sentido subjetivos", a partir da qual se constituem as configurações subjetivas. Estas são, então, “[...] a própria experiência como subjetivamente vivida” (GONZÁLEZ REY, 2012, p. 28), o que nos possibilita entender a motivação como uma “[...] organização subjetiva de diferentes processos que fazem parte da atividade atual da pessoa." (GONZÁLEZ REY, 2012, p. 40).

Essa compreensão converge para as construções de Mitjáns Martínez (2012b) acerca da aprendizagem criativa. Para a autora, um dos aspectos que caracterizam essa forma complexa de aprendizagem é a produção de processos simbólicos e emocionais que favorecem a geração de novidade, os quais, recursivamente, alimentam essa forma de aprendizagem. Nos três casos apresentados, interpretamos que os sentidos subjetivos que se constituíam no decorrer do trabalho pedagógico criativo "alimentavam" essa expressão criativa e se configuravam como motivos para a criatividade das professoras.

Essas construções sobre as especificidades das inter-relações entre a criatividade no trabalho pedagógico das professoras e a movimentação subjetiva em cada uma delas nos possibilitaram, então, formular a tese: os processos subjetivos que configuram a criatividade no trabalho pedagógico do professor são singulares, históricos e atuais e se relacionam de forma recursiva aos próprios processos de movimentos na subjetividade do docente.

Sintetizamos as nossas construções quanto aos processos subjetivos que participam da expressão criativa do professor no trabalho pedagógico como: a) a forma como cada docente subjetiva o papel do professor, vinculado à responsabilidade frente ao trabalho pedagógico; b) como subjetiva o aluno, ativo e participativo no processo de aprendizagem; c) a subjetivação da aprendizagem escolar relacionada à compreensão e a elaboração pessoal a partir do aprendido; d) a subjetivação da função social da educação voltada à formação integral dos estudantes, o que abrange o contato com diferentes áreas do conhecimento; assim como, e) a subjetivação de conhecimentos em áreas específicas, que se relacionam às necessidades pedagógicas que se constituem no cotidiano educativo e aos temas de interesse dos professores, que estão para além do campo profissional, abrangem outros assuntos vinculados a interesses de modo geral.

Outra construção relevante que sintetizamos, nesse momento, diz respeito ao aluno como um outro social que participa da criatividade no trabalho pedagógico do professor, por meio de demandas, desafios e necessidades pedagógicas que, em conjunto com a organização subjetiva do docente, implicam essa expressão criativa. 
Avançamos, ainda, quanto à imaginação dos professores na criatividade no trabalho pedagógico, como processo subjetivo que integra o momento de planejamento do trabalho pedagógico e pode se constituir, também, como um recurso pedagógico do professor.

Especificamos a condição de sujeito do professor na sua atuação profissional, o que envolve sua intencionalidade pedagógica, sua autoria e protagonismo no trabalho pedagógico. Aspectos que se relacionam aos núcleos subjetivos específicos que participam dessa expressão criativa, os quais se atualizam no curso da criatividade no trabalho pedagógico e podem, de acordo com a organização subjetiva de cada professor, possibilitar movimentos, mudanças ou desenvolvimento subjetivo. Essa construção, portanto, evidencia o valor da criatividade para o próprio docente e se vincula à recursividade entre a criatividade no trabalho pedagógico do professor e os movimentos em sua subjetividade.

Por fim, o nosso estudo aponta para o funcionamento psicológico criativo, a dimensão funcional da criatividade, que implica a possibilidade do professor gerar alternativas singulares e autônomas frente às situações pessoalmente significativas, sendo a base para a produção de novidades com valor para a aprendizagem dos estudantes.

Consideramos que tais construções acerca dos processos subjetivos que participam da criatividade no trabalho pedagógico do professor avançam quanto às colocações de Mitjáns Martínez (2008a), que afirma a participação do exercício da condição de sujeito, a subjetividade individual do professor e a subjetividade social do espaço escolar nessa expressão criativa. Ampliamos a compreensão em relação a alguns processos subjetivos específicos constituídos na organização subjetiva do professor, os quais se integram aos sentidos subjetivos, às configurações, aos núcleos subjetivos constituídos historicamente.

Esses aspectos nos permitem avançar no entendimento da singularidade da expressão criativa no trabalho pedagógico, na perspectiva da criatividade como processo complexo da subjetividade humana. Assim como, avançarmos no entendimento acerca da participação da subjetividade individual dos docentes em sua expressão criativa. Criatividade no trabalho pedagógico do professor envolve duas dimensões articuladas entre si: a instrumental e a funcional. 


\section{CONSIDERAÇÕES FINAIS}

Nesta pesquisa, estudar a criatividade no trabalho pedagógico do professor constituiu-se como um processo envolvente e instigador, que, a cada passo, renovava a esperança na educação brasileira. O nosso estudo guiava-se para práticas educativas exitosas, com caráter novo e valioso, que favorecessem aos estudantes avanços em sua aprendizagem. No percurso, percebemos que o "valor" da expressão criativa no trabalho pedagógico não se restringia aos alunos, os professores criativos também se beneficiavam do processo criativo, por meio das produções subjetivas que emergiam da elaboração e realização de sua própria proposta de ensino.

Temos clareza que a esperança na educação permeou todos os momentos do estudo, evidenciando a participação da subjetividade da pesquisadora, nas leituras, nas discussões, enfim, no seu olhar construtivo-interpretativo a respeito do trabalho pedagógico. Isso, entretanto, não minimizou os desafios vividos ao longo da pesquisa, que tinha como foco compreender processos subjetivos que configuram a criatividade no trabalho pedagógico do professor e suas inter-relações com o movimento em sua subjetividade, tema, por si só, desafiador, que nos mobilizou para busca de novas zonas de sentido, contribuições práticas para o campo da educação, bem como, para formas metodológicas diversas de investigação.

Dentre os desafios da pesquisa, reconhecemos as dificuldades geradas pela organização do trabalho pedagógico das instituições educativas. Tínhamos em vista, inicialmente, aproximarmo-nos dos momentos de coordenação pedagógica e do processo de planejamento das atividades educativas realizadas em sala de aula. No entanto, vários fatores dificultaram essa aproximação, como: a própria utilização dos espaços de coordenação pedagógica, que pouco servem para o planejamento das ações docentes; a série de eventos e datas comemorativas que se inseriam na dinâmica educativa e que implicavam acordos entre os professores e as equipes de direção, a confecção de enfeites durante o horário de coordenação pedagógica; presenciamos falta de energia e de água em duas instituições que impediam, inclusive, as aulas; existia um "medo" de que as fragilidades, os acordos administrativos fossem denunciados, e outros tantos aspectos que solicitavam criatividade dos professores e da pesquisadora.

Além disso, assumimos os desafios advindos da especificidade de um estudo que se volta à subjetividade dos professores, as relações entre o individual e o social para a expressão criativa. Nesse percurso, compreendemos que as participantes do estudo de casos não se 
sentiam completamente à vontade para se colocarem diante de algumas questões relacionadas ao espaço social da instituição e das interações que ocorriam ali, entre elas e outros professores, ou entre elas e as equipes de direção. Esses aspectos dificultaram a aproximação às relações com outros profissionais do contexto escolar e às famílias, bem como ao estudo dessas relações e a criatividade no trabalho pedagógico do professor. Outros assuntos, que envolviam situações familiares particulares, também, solicitaram cuidados por parte da pesquisadora. Tínhamos o dever ético de respeitar os limites colocados pelas professoras.

Nesse processo de estudo, consideramos algumas limitações. Dentre elas, ressaltamos o tempo disponível e, de certa maneira, o caráter limitador que a formação em quatro anos exige do pesquisador. Tempo que dificultou construções acerca dos elementos constitutivos da subjetividade social das instituições onde atuavam as professoras Ananda, Júlia e Laura, e o estudo das inter-relações entre a criatividade no trabalho pedagógico do professor e o desenvolvimento da subjetividade individual dos docentes, o que construímos em apenas um caso, num processo de retomada das experiências vividas.

Ainda assim, concluímos que a pesquisa desenvolvida proporcionou novas zonas de sentido, como coloca a Epistemologia Qualitativa, e nos permitiu abrir inteligibilidade sobre alguns dos processos subjetivos que configuram a criatividade no trabalho pedagógico do professor e suas inter-relações com o movimento em sua subjetividade. Defendemos, então, a nossa contribuição teórica no que se refere a tais processos, isto é, a compreensão a respeito da subjetivação de alguns aspectos que participam da criatividade no trabalho pedagógico do professor e, mais, o aluno nessa expressão criativa.

Consideramos, ainda, as construções sobre a imaginação do professor em sua criatividade nas práticas educativas; sua condição de sujeito, que se revela na intencionalidade pedagógica, na autoria e protagonismo; a integração entre a dimensão funcional, um funcionamento psicológico criativo, e dimensão instrumental da criatividade. Essas construções podem ser consideradas como avanços para o entendimento acerca da participação da subjetividade individual do professor na criatividade no trabalho pedagógico, como afirma Mitjáns Martínez (2004, 2008a).

Outra contribuição teórica diz respeito à compreensão da recursividade entre os processos subjetivos organizados na subjetividade individual do professor, que são determinantes para a autoria e protagonismo docente no trabalho pedagógico, e as produções subjetivas que se atualizam a partir dos sentidos subjetivos que se constituem no curso das experiências criativas e que movimentam núcleos subjetivos relacionados a essa criatividade, 
favorecendo, por sua vez, a possibilidade do movimento, da mudança ou do desenvolvimento da subjetividade individual do professor.

Nessa perspectiva, acrescentamos como contribuição prática a importância da formação docente, inicial e em serviço, para a criatividade no trabalho pedagógico. Mais que quantidade de títulos e certificados, ou de práticas educativas prontas, mostrou-se essencial que a formação docente viabilize tanto conhecimentos relacionados ao fazer pedagógico, campos específicos de interesse particular dos docentes, como a personalização do aprendido, o exercício da condição de sujeito do professor em sua prática profissional. Que os espaços formativos avancem para além da reprodução do discurso pedagógico e favoreçam a compreensão e a ação criativa no processo de aprendizagem dos próprios professores.

Como contribuição metodológica, indicamos a articulação entre instrumentos já legitimados no estudo da subjetividade, como o completamento de frases e a redação, e a produção de outros, que permitam o acesso a informações específicas, relacionadas ao foco de interesse. No nosso estudo, produzimos dois instrumentos novos e adaptamos outros, para assim, conseguirmos avançar no processo construtivo-interpretativo. Esses instrumentos, selecionados para a pesquisa, possuíam como objetivo resgatar experiências pedagógicas e pessoais anteriores ao estudo. E, por outro lado, nos possibilitar construções acerca das produções subjetivas que se constituíam no momento atual vivenciado pelas participantes.

Reconhecemos, nesse processo de pesquisa, que existem muitas vias de estudo em relação à criatividade no trabalho pedagógico do professor e suas inter-relações com a subjetividade individual e social. Apontamos algumas possibilidades de estudos futuros, certas de que ainda há muito para avançar na compreensão da criatividade no trabalho pedagógico do professor, na perspectiva de que esse é um processo da subjetividade humana. Listamos essas perspectivas, como: o estudo das inter-relações entre a expressão criativa do professor e o seu desenvolvimento subjetivo para além do campo profissional; a investigação das relações no contexto educativo (com alunos e outros profissionais) e a criatividade do professor; o papel dos processos emocionais para a constituição dessa criatividade; as interrelações entre a expressão criativa docente e a subjetividade social da instituição educativa; as relações entre os recursos tecnológicos e a criatividade do professor; as relações entre criatividade no trabalho pedagógico e a saúde dos docentes, o seu modo de vida; dentre outras tantas vertentes de pesquisa.

Finalizamos essas considerações com a convicção de que a área de estudo da criatividade no trabalho pedagógico do professor e suas inter-relações com o movimento em 
sua subjetividade é um campo de pesquisa aberto, em que outras contribuições teóricas, práticas e metodologias podem ser feitas. Durante o processo de pesquisa, almejamos colaborar para essa área, e julgamos que favorecemos novas zonas de sentido no que se refere à compreensão de processos subjetivos que constituem essa expressão criativa e sua articulação com o movimento da subjetividade individual dos professores, dentro das limitações que se formaram no percurso. 


\section{REFERÊNCIAS}

ALENCAR, E. S. Criatividade e Educação de Superdotados. Petrópolis, RJ: Editora Vozes, 2001.

ALENCAR, E. S.; FLEITH, D. S. Criatividade: múltiplas perspectivas. 3 ed. Brasília: Editora Universidade de Brasília, 2003.

ALENCAR, E. M. L. S.; FLEITH, D. de S. Inventário de práticas docentes que favorecem a criatividade no ensino superior. Psicol. Reflex. Crit., v. 17, n. 1, p. 105-110. 2004.

ALENCAR, E. M. L. S.; FLEITH, D. de S. Barreiras à Promoção da Criatividade no Ensino Fundamental.Psic.: Teor. e Pesq., v. 24, n. 1, p. 59-65. 2008.

ALENCAR, E. M. L. S.; FLEITH, D. de S. Escala de Práticas Docentes para a Criatividade na Educação Superior. Aval. Psicol., v. 9, n.1, p. 13-24. 2010.

ALJUGHAIMAN, A. M. Teachers' perceptions of creativity and creative students. 2002. 195 f. Dissertation (PhD) - University of Idaho, Moscow. 2002.

ALMEIDA, J. M. O. O Ensino Médio e as Práticas Docentes Adotadas para Expressão e Desenvolvimento da Criatividade. 2007. 81 f. Dissertação (Mestrado em Educação) Universidade Católica de Brasília, Brasília, 2007.

ALVES-MAZZOTTI, A. J.; GEWANDSZNAJDER, F. O Método nas Ciências Naturais e Sociais: pesquisa quantitativa e qualitativa. São Paulo, SP: Pioneira Thomson Learning, 1999.

AMARAL, A. L. S. N. do. A Constituição da Aprendizagem Criativa no Processo de Desenvolvimento da Subjetividade. 2011. 250 f. Tese (Doutorado em Educação) Faculdade de Educação, Universidade de Brasília, Brasília, 2011.

ANARUMA, S. M. Vivências em Criatividade para Professore: relato de uma experiência. In: GIGLIO, Z. G. (Org.). De Criatividade e de Educação. Campinas, SP: UNICAMP, NEP, p. 91-138. 1992.

ANDILIOU, A.; MURPHY, P. K. Examining variations among researchers' and teachers' conceptualizations of creativity: A review and synthesis of contemporary research.

Educational Research Review, v. 1.5 (3), p. 201-219. 2010.

AQUINO, R. A. da C. M. Percepção de Professores e Estudantes do Curso de Pedagogia sobre o Ensino Promotor da Criatividade. 2012. 66 f. Dissertação (Mestrado em Educação) - Universidade Católica de Brasília, Brasília, 2012.

ARRUDA, T. S. O Desenvolvimento do Currículo e a Criatividade do Professor: uma reflexão em busca da qualidade da Educação Infantil. 2007. 252 f. Dissertação (Mestrado em Educação) - Faculdade de Educação, Universidade de Brasília, Brasília, 2007.

ARRUDA, T. S.; MITJÁNS MARTÍNEZ, A. Criatividade do Professor e Criatividade no Trabalho Pedagógico: os estudos realizados no Brasil. Linguagens, Educação e Sociedade Teresina, Ano 17, n. 27, p. 179-208, jul./dez. 2012 
ASCHENBRENER, M.; TERRY, R. J.; TORRES, R. M. Creative teaching behaviors: a comparison of student and instructor perspectives. NACTA Journal, v. 54, n. 1, p.46- 59. 2010 .

ASSIS, L. de C. Práticas e Atributos Pessoais Docentes que Favorecem o Desenvolvimento da Criatividade dos Alunos na Educação Infantil. 2009. $81 \mathrm{f}$.

Dissertação (Mestrado em Educação) - Universidade Católica de Brasília, Brasília, 2009.

BACHERT, C. M. D. et al. Criatividade e educação: análise da produção científica. In: CONGRESSO INTERNACIONAL DE CRIATIVIDADE E INOVAÇÃO, 2011, Manaus. Visão e prática em diferentes contextos: anais... Manaus: CRIABRASILIS, 2011. p. 346353.

BARRETO, M. O.; MARTINEZ, A. M. Possibilidades Criativas de Professores em Cursos de Pós-Graduação Stricto Sensu. Estud.Psicol., Campinas, v. 24, n. 4, p. 463-473. 2007.

BOLDEN, D. S.; HARRIES, T. V.; NEWTON, D. P. Pre-service primary teachers' conceptions of creativity in mathematics. Educ Stud Math. v.73, p. 143-157. 2010.

BRASIL. Lei de Diretrizes e Bases da Educação Nacional. Estabelece as diretrizes e bases da educação nacional. Diário Oficial [da] República Federativa do Brasil. Brasília DF, 23 dez. 1996. Seção 1, p. 27-833.

BRUNO-FARIA, M. de F. et al. Criatividade nas organizações: análise da produção científica nacional em periódicos e livros de Administração e Psicologia. Rev. Psicol., Organ. Trab., v. 8, n. 1, p. 142-163. 2008.

CAGLE, J. M. Faculty perceptions of institutional climate as it affects creativity in curriculum development and classroom activities. 2002. 115 f. Dissertation (PhD) Capella University, Minneapolis, MN, 2002.

CARDOSO, M. R.; LEITE, N. S. de F.Criatividade e Saúde: a inovação na Perspectiva da Educação. Revista Eletrônica de Ciências da Educação, Campo Largo, v. 8, n. 1, 2009.

CARVALHO, O. Elementos Favorecedores e Inibidores da Criatividade na Prática Docente, Segundo Professores de Geografia. 2004. 82f. Dissertação (Mestrado em Educação) - Universidade Católica de Brasília, Brasília, 2004.

CASANGIU, L. I. Techniques that Stimulates Creativity in Primary School, During the Activities of Communication. Journal Plus Education. v. VI, n. 1, p 148-156. 2010.

CASTRO, J. S. R. de.Criatividade Escolar: relação entre tempo de experiência docente e tipo de escola. 2007. 94 f. Dissertação (Mestrado em Psicologia) - Instituto de Psicologia, Universidade de Brasília, Brasília, 2007.

CASTRO, J. S. R. de; FLEITH, D. de S. Criatividade escolar: relação entre tempo de experiência docente e tipo de escola.Psicol. Esc.Educ. v. 12, n. 1, p. 101-118. 2008.

CHANG,C. P.; CHUANG, H. W.; BENNINGTON, L. Organizational climate for innovation and creative teaching in urban and rural schools. Quality and Quantity. v. 45, n. 4, p. 935952. 2011. 
CHENNABATHNI, R. Case-study of a creative teacher. 2006. Dissertation (Ph. D.) McGill University, Montreal, Canada.

CHIODI, M. G.; FARIAS, E. S.; WECHSLER, S. M. Percepção docente acerca do aluno inteligente e criativo. Intellectus. Revista Acadêmica Digital das Faculdades UNOPEC, v. 7, p. 29-39. 2011.

CORES, C. I. A Criatividade do Professor em Situação de Inclusão Escolar. 2006. 120 f. Dissertação (Mestrado em Educação) - Faculdade de Educação, Universidade de Brasília, Brasília, 2006.

COSTA JÚNIOR, J. R. S. A Criatividade na Prática Docente do Professor de Arte: um estudo exploratório nas escolas públicas de Teresina - PI. 2008120 f. Dissertação (Mestrado em Educação) - Fundação Universidade Federal do Piauí, Terezina, 2008.

CRAFT, A. Creativity in schools. In: JACKSON, N. (Coord.). Developing creativity in higher education: an imaginative curriculum. London: Routledge, 2006. p. 19-28.

CROWE, B. D. I ain't fattening frogs for snakes: inquiry into application of creativity research to teaching practice. 2010. $145 \mathrm{f}$. Dissertation (Doctoral in Philosophy in Integral Studies) - Faculty of the California Institute of Integral Studies, San Francisco, CA, 2010.

CUNHA, M. D. Algumas questões sobre a subjetividade social no processo de constituição de professores: o coletivo da escola. Educação e Filosofia, v. 18, n. 35-36, p. 13-33, 2004.

CUNHA, M. D. Subjetividade e constituição de professores. In: GONZÁLEZ REY, F. L. (Org.). Subjetividade, Complexidade e Pesquisa em Psicologia. São Paulo: Pioneira Thomson Learning, 2005. p. 191-214.

DE LA TORRE, S. Dialogando com a criatividade: da identificação à criatividade paradoxal. São Paulo: Madras, 2005.

DE LA TORRE, S. Evaluar la creatividad docente del professorado creativo. In: DE LA TORRE, S.; VIOLANT, V. (Org.). Comprender y evaluar la creatividad. Malaga: Ediciones Aljibe, 2006. v. 2, p. 683-692.

DOMINGUES, K. G. Prometeu em sala de aula: o professor e sua representação social do aluno criativo. 2008. 141 f. Dissertação (Mestrado em Educação) - Universidade de Brasília, Brasília, 2008.

EYSTER, L. Encouraging creativity in the science lab: a series of activities designed to help students think outside the box. The Science Teacher, v. 77, n. 6, 2010.

FERNANDES, V. L. P. A criatividade no trabalho pedagógico do professor de Artes Visuais no ensino médio, no contexto da educação inclusiva. 2011. $270 \mathrm{f}$. Tese (Doutorado em Educação) - Fundação Universidade Federal de Mato Grosso do Sul, Campo Grande, 2011.

FLEITH, D. de S. A promoção da criatividade no contexto escolar. In: VIRGOLIM, A. M. R. (Org.). Talento criativo: expressão em múltiplos contextos. Brasília, DF: Editora Universidade de Brasília, 2007. p. 143-158. 
FLEITH, D. de S. Desenvolvimento da criatividade na educação fundamental: teoria, pesquisa e prática. In: WECHSLER, S. M.; SOUZA, V. L. T. (Org.). Criatividade e aprendizagem: caminhos e descobertas em perspectiva internacional. São Paulo: Edições Loyola, 2011. p. $33-52$.

FREITAS, L. C. Crítica da Organização do Trabalho Pedagógico e da Didática. Campinas - SP: Papirus, 1995.

FRESQUET, A. M. Processo de co-construção do conceito de criatividade professores de educação infantil: uma análise microgenética. 2000. 171 f. Dissertação (Mestrado em Psicologia) - Universidade de Brasília, Brasília, 2000.

GARDE, M. Criatividade: um estudo sobre as representações e crenças de professores do ensino médio. 2003. 124 f. Dissertação (Mestrado em Filosofia, Ciência e Letras) Universidade de São Paulo, Faculdade de Filosofia, Ciência e Letras de Ribeirão Preto, Ribeirão Preto, 2003.

GARDE, M.; ANDRADE, A. S. Criatividade: um estudo sobre as representações e crenças dos professores do ensino médio. In: SEMINÁRIO DE PESQUISA, 6., 2003, Ribeirão Preto. Livro de artigos... Ribeirão Preto: FFCLRP, 2003. Tomo 2, p. 183-192.

GIBSON, R. The "Art" of creative teaching: implications for higher education. Teaching in Higher Education, v. 15, n. 5, p. 607-613, 2010.

GODINHO, M. L. de M. Práticas docentes de professores de língua inglesa: facilitadores e barreiras ao desenvolvimento da criatividade. 2008. 73 f. Dissertação (Mestrado em Educação) - Universidade Católica de Brasília, Brasília, 2008.

GONZÁLEZ REY, F. L.; MITJÁNS MARTÍNEZ, A. La personalidad: su educación y desarrollo. 3 ed. Ciudad de la Havana, Cuba: Editorial Pueblo y Educación, 1989.

GONZÁLEZ REY, F. L. Comunicación, personalidad y desarrollo. Ciudad de la Havana, Cuba: Editorial Pueblo y Educación, 1995.

GONZÁLEZ REY, F. L. Epistemología cualitativa y subjetividad. Ciudad de la Havana, Cuba: Editorial Pueblo y Educación, 1997.

GONZÁLEZ REY, F. L. Psicologia e educação: desafios e projeções. In: RAYS, O. A. (Org.). Trabalho pedagógico: realidade e perspectivas. Porto Alegre: Sulina, 1999. p. 102117.

GONZÁLEZ REY, F. L. Saúde e subjetividade: desafios para a investigação em psicologia da saúde. Universistas Psicologia, Brasília, v. 1, n.1, p. 25-44, 2000.

GONZÁLEZ REY, F. L. Pesquisa qualitativa em psicologia: caminhos e desafios. São Paulo: Pioneira Thomson Learning, 2002.

GONZÁLEZ REY, F. L. Sujeito e subjetividade: uma aproximação histórico-cultural. São Paulo, SP: Pioneira Thomson Learning, 2003.

GONZÁLEZ REY, F. L. O social na psicologia e a psicologia social: a emergência do sujeito. Petrópolis: Vozes, 2004a. 
GONZÁLEZ REY, F. L. O sujeito, a subjetividade e o outro na dialética complexa do desenvolvimento humano. In: MITJÁNS MARTINEZ, A.; SIMÃO, M. L. (Org.). O outro no desenvolvimento humano. São Paulo: Pioneira Thomson Learning, 2004b. p. 1-28.

GONZÁLEZ REY, F. L. O valor heurístico da subjetividade na investigação psicológica. In: GONZÁLEZ REY, F. L. (Org.). Subjetividade, complexidade e pesquisa em psicologia. São Paulo: Pioneira Thomson Learning, 2005a.

GONZÁLEZ REY, F. L. Pesquisa qualitativa e subjetividade: os processos de construção da informação. São Paulo: Pioneira Thomson Learning, 2005b.

GONZÁLEZ REY, F. L. As categorias sentido, sentido pessoal e sentido subjetivo: sua evolução e diferenciação na teoria histórico-cultural. Psicologia da Educação, v. 24, p. 155$179,2007 \mathrm{a}$.

GONZÁLEZ REY, F. L. Psicoterapia, subjetividade e pós-modernidade: uma aproximação histórico-cultural. São Paulo: Pioneira Thomson Learning, 2007b.

GONZÁLEZ REY, F. L. O sujeito que aprende: desafios do desenvolvimento do tema da aprendizagem na psicologia e na prática pedagógica. In: TACCA, M. C. V. R. (Org.) Aprendizagem e trabalho pedagógico. 2 ed. Campinas: Alínea, 2008. p. 29-44.

GONZÁLEZ REY, F. L. Questões teóricas e metodológicas nas pesquisas sobre a aprendizagem: a aprendizagem no nível superior. In: MITJÁNS MARTÍNEZ, A; TACCA, M. C. V. R. A complexidade da aprendizagem: destaque ao ensino superior. Campinas: Alínea, 2009. p. 119-148.

GONZÁLEZ REY, F. L. El pensamiento de Vigotsky: contradicciones, desdoblamientos y desarrollo. México: Trilhas, 2011a.

GONZÁLEZ REY, F. L. Subjetividade e saúde: superando a clínica da patologia. São Paulo: Cortez, 2011b.

GONZÁLEZ REY, F. L. Lenguaje, sentido y subjetividad: yendo más allá del lenguaje y el comportamiento. Estudios de Psicología, v. 32, p. 345-357, 2011 c.

GONZÁLEZ REY, F. L. A configuração subjetiva dos processos psíquicos: avançando na compreensão da aprendizagem como produção subjetiva. In: MITJÁNS MARTÍNEZ, A. et al. (Org.). Ensino e aprendizagem: a subjetividade em foco. Brasília, DF: Liber Livros, 2012. p. 21-42.

GONZÁLEZ REY, F. L. A imaginação como produção subjetiva: as ideias e os modelos da produção intelectual. In: MITJÁNS MARTÍNEZ, A; ÁLVAREZ, P. (Org.). O sujeito que aprende: diálogo entre a psicanálise e o enfoque histórico-cultural. Brasília, DF: Liber Livro, 2014. p. 35-62.

GRAVIÉ, R. F. La pieza clave del rompecabezas para desarrollar la creatividad: la escuela. In: FERRERO, R. et al. (Org.). La creatividad: um bien cultural de la humanidade. México: Trillas, 2008. p. 109- 135. 
GUMS, E. Criatividade e auto-percepção de estratégias de ensino em professores alfabetizadores de adultos. 2003. 78 f. Dissertação (Mestrado em Psicologia) - Pontifícia Universidade Católica de Campinas, Campinas, 2003.

HANSEN, D. T. Creativity in teaching and building a meaningful life as a teacher. The Journal of Aesthetic Education, v. 39, n. 2, p. 57-68, 2005.

HONG, M. ; KANG, N. H. South Korean and the us Secondary School: science teachers' conceptions of creativity and teaching for creativity. International Journal of Science and Mathematics Education. v. 8, p. 821-843, 2010.

HORNG, J. S. et al. Creative teachers and creative teaching strategies. International Journal of Consumer Studies, v. 29, n. 4, p. 352-358, July 2005.

JEFFREY, B. Creative teaching and learning: towards a common discourse and practice. Cambridge Journal of Education, v. 36, n. 3, p. 399-414, 2006.

JEFFREY, B; CRAFT, A. Teaching creatively and teaching for creativity: distinctions and relationships. Educational Studies, v. 30, n. 1, p. 77 - 87, 2004.

KAUFMAN, J. C. et al. Criatividade na sala de aula. In: WECHSLER, S. M.; SOUZA, V. L. T. (Org.). Criatividade e aprendizagem: caminhos e descobertas em perspectiva internacional. São Paulo: Edições Loyola, 2011. p. 53-72.

KHAN, N. Impact of creative talent on the performance of teacher trainees of distance mode. Indian Journal of Open Learning, v. 17, n. 1, p. 95-100. 2008.

KINNEY, P. M. Creativity in japanese and american primary teaching practices. 2005. $188 \mathrm{f}$. Thesis (Master) - State University of New York Empire State College, New York, NY, 2005.

KRAMER, S. Direitos da criança e projeto político-pedagógico da educação infantil. In: BASÍLIO, L. C., KRAMER, S. Infância, educação e direitos humanos. Campinas: Cortez, 2003.

KRAMER, S. Infância e currículo: paradoxos, mudanças e riscos. In: MOREIRA, A. F. B.; ALVES, M. P. C.; GARCIA, R. L. (Org.). Currículo, cotidiano e tecnologias. Araraquara: Junqueira \& Marin, 2006.

LIBÓRIO, A. C. O.; NEVES, M. M. B. da J. Interações sociais e clima para criatividade em sala de aula. Aletheia [online], n. 31, p. 168-183, 2010.

LIBÓRIO, A. C. O. As interações professor-aluno e o clima para criatividade em sala de aula: possíveis relações. 2009. 119 f. Dissertação (Mestrado em Processos do Desenvolvimento Humano e Saúde) - Universidade de Brasília, Brasília, 2009.

LILLY, F. R. Teaching outside of the box: studying a creative teacher. 2002. $198 \mathrm{f}$. Dissertation (Ph. D.) - McGill University, Montreal, Canada, 2002.

LIMA, V. B. F. Percepção de professores de cursos de pós-graduação stricto sensu em educação sobre criatividade em sua prática docente: limites e possibilidades. $2010.93 \mathrm{f}$. Dissertação (Mestrado) - Universidade Católica de Brasília, Brasília, 2010. 
LUDKE, M.; ANDRÉ, M. E. D. A. Pesquisa em educação: abordagens qualitativas. São Paulo: EPU, 1986.

MARIANI, M. de F. Criatividade e trabalho pedagógico: limites e possibilidades na expressão da criatividade do professor de história. 2001. 94 f. Dissertação (Mestrado) Universidade Católica de Brasília, Brasília, 2001.

MARIANI, M. de F. M.; ALENCAR, E. M. L. S. de. Criatividade no trabalho docente segundo professores de história: limites e possibilidades. Psicologia Escolar e Educacional, v. 9 , n. 1 , p. 27-35, 2005.

MELO, Ana C. R. de. Educação física adaptada e criatividade: uma investigação sobre a opinião dos professores. 2001. 91 f. Dissertação (Mestrado em Educação) - Universidade Católica de Brasília, Brasília, 2001.

MELO, Ângela S. S. de. Percepção de alunos e professores do $7^{\circ}$ ano do ensino fundamental em relação aos fatores promotores da criatividade em sala de aula. 2013. 82 f. Dissertação (Mestrado) - Universidade Católica de Brasília, Brasília, 2013.

MEYER, A. A. Teaching for creativity: modify existing lessons and labs to promote creativity in your classroom. The Science Teacher, v. 79, n. 5, 2012.

MITJÁNS MARTINEZ, A. Pensar, crear y transformar: desafíos para la educación. In: SIMPÓSIO MULTIDISCIPLINAR PENSAR, CRIAR E TRANSFORMAR, 2000, São Paulo. Anais... São Paulo: Unimarco, 2000.

MITJÁNS MARTINEZ, A. A criatividade na escola: três direções de trabalho. Revista Linhas Críticas, Brasília, v. 8, n. 15, p. 189-206, 2002.

MITJÁNS MARTINEZ, A. Criatividade, personalidade e educação. 3 ed. Campinas: Papirus, 2003a.

MITJÁNS MARTINEZ, A. La investigación sobre personalidad y creatividad en Cuba. Revista de Psicologia, Lima, Peru, v. 6, n. 2, p. 171-178, 2003 b.

MITJÁNS MARTINEZ, A.Criatividade e deficiência: por que parecem distantes? Revista Linhas Críticas, Brasília, v. 9, n. 16, p. 73-86, 2003 c.

MITJÁNS MARTÍNEZ, A. O outro e sua significação para a criatividade: implicações educacionais. In: MITJÁNS MARTINEZ, A.; SIMÃ̃, M. L. (Org.). O outro no desenvolvimento humano. São Paulo: Pioneira Thomson Learning, 2004. p. 77-100.

MITJÁNS MARTÍNEZ, A. A teoria da subjetividade de González Rey: uma expressão do paradigma da complexidade. In: GONZÁLEZ REY, F. L. (Org.). Subjetividade, complexidade e pesquisa em psicologia. São Paulo: Pioneira Thomson Learning, 2005.

MITJÁNS MARTÍNEZ, A. Criatividade no trabalho pedagógico e criatividade na aprendizagem: uma relação necessária? In: TACCA, M. C. V. R. (Org.). Aprendizagem e trabalho pedagógico. 2 ed. Campinas: Alínea, 2008a. p. 69- 94. 
MITJÁNS MARTÍNEZ, A. A criatividade como princípio funcional da aula: limites e possibilidades. In: VEIGA, I. P. A. (Org.). Aula: gênese, dimensões princípios e práticas. Campinas: Papirus, 2008b. p. 115-143.

MITJÁNS MARTÍNEZ, A. El dialéctico perfil de las personas creativas. In: FERRERO, R. et al. (Org.) La creatividad: un bien cultural de la humanidad. México: Trillas, 2008c. p. 55-68.

MITJÁNS MARTÍNEZ, A. Vygotsky e a criatividade: novas leituras, novos desdobramentos. In: GIGLIO, Z.; WECHSLER, S.; BRAGOTTO, D. (Org.). Da criatividade à inovação. Campinas: Papirus, 2009a.

MITJÁNS MARTÍNEZ, A. Processos de aprendizagem na pós-graduação: um estudo exploratório. In: MITJÁNS MARTÍNEZ, A; TACCA, M. C. V. R. A complexidade da aprendizagem: destaque ao ensino superior. Campinas: Alínea, 2009b. p. 213-262.

MITJÁNS MARTÍNEZ, A.; GONZÁLEZ REY, F. L. O subjetivo e o operacional na aprendizagem escolar: pesquisas e reflexões. In: MITJÁNS MARTÍNEZ, A; SCOZ, B. J. L.; CASTANHO, M. I. S. (Org.). Ensino e aprendizagem: a subjetividade em foco. Brasília: Liber Livro, 2012. p. 59-84.

MITJÁNS MARTÍNEZ, A. Aprendizagem criativa: desafios para a prática pedagógica. In: NUNES, C. P. (Org.). Didática e formação de professores. Ijuí: Ed. Unijuí, 2012a. p. 93124.

MITJÁNS MARTÍNEZ, A. Aprendizagem criativa: uma aprendizagem diferente. In: MITJÁNS MARTÍNEZ, A.; SCOZ, B. J. L.; CASTANHO, M. I. S. (Org.). Ensino e aprendizagem: a subjetividade em foco. Brasília: Liber Livro, 2012b. p. 85-110.

MITJÁNS MARTÍNEZ, A. O lugar da imaginação na aprendizagem escolar: suas implicações para o trabalho pedagógico. In: MITJÁNS MARTÍNEZ, A e ÁLVAREZ, P. (Org.). O sujeito que aprende: diálogo entre a psicanálise e o enfoque histórico-cultural. Brasília: Liber Livro, 2014. p. 63-98.

MONTEIRO, A. N; MORAIS, M. F.; BRAGA, A. C.; NAKANO, T. C. Representações sobre Criatividade: diferenças entre docentes portugueses do ensino básico e secundário. Revista AMAzônica, v. 11, n. 2, 2013. p. 327-357.

MORAES, G. M. L. e. Percepção de professores de língua portuguesa sobre criatividade em produções textuais. 2012. 76 f. Dissertação (Mestrado em Educação) - Universidade Católica de Brasília, Brasília, 2012.

MORAIS, M. de F.; AZEVEDO, I. What is a creative teacher and what is a creative pupil? Perceptions of teachers. Procedia Social and Behavioral Sciences, n. 12, p. 330-339, 2011.

MORIN, E. Introdução ao pensamento complexo. Porto Alegre: Sulina, 2005.

MOURÃO, R. F. Criatividade do professor: sentido e ação - um estudo da relação entre o sentido subjetivo da criatividade do professor e sua prática pedagógica com projetos. 2004. 143 f. Dissertação (Mestrado em Psicologia) - Universidade de Brasília, Instituto de Psicologia, Brasília, 2004. 
NAKANO, T. de C.; WECHSLER, S. M. Criatividade, características da produção científica brasileira. Avaliação Psicológica, v. 6, n. 2, p. 261-270, 2007.

NAKANO, T. de C. Investigando a criatividade junto a professores: pesquisas brasileiras. Revista Semestral da Associação Brasileira de Psicologia Escolar e Educacional (ABRAPEE), v. 13, n. 1, p. 45-53, 2009.

NAKANO, T. de C. Criatividade na visão de professores: definição e uso na prática profissional. Intellectus, Revista Acadêmica Digital das Faculdades UNOPEC, v. 7, p. 7$28,2011$.

NEUBERN, M. S. A subjetividade como noção fundamental do novo paradigma: breve ensaio. In: GONZÁLEZ REY, F. L. (Org.). Subjetividade, complexidade e pesquisa em psicologia. São Paulo: Pioneira Thomson Learning, 2005. p. 53-80.

NEVES-PEREIRA, M. S. Criatividade na educação infantil: um estudo sociocultural construtivista de concepções e práticas de educadores. 2004. 283f. Tese (Doutorado em Psicologia) - Universidade de Brasília, Brasília, 2004.

NEWTON, L.; BEVERTON, S. Teachers's conceptions of creativity in pre-service English elementary school. Thinking Skills and Creativity, v. 7, n. 3, p. 165-176, 2012.

OLIVEIRA, Ana L. A. Percepção de professores do ensino fundamental sobre procedimentos úteis à promoção da criatividade em sala de aula. Brasília, DF, 2002. $82 \mathrm{f}$. Dissertação (Mestrado em Educação) - Universidade de Católica de Brasília, Brasília, 2002.

OLIVEIRA, Eny da L. L.; ALENCAR, E. M. L. S. de. Criatividade e Escola: limites e possibilidades segundo gestores e orientadores educacionais. Revista Semestral da Associação Brasileira de Psicologia Escolar e Educacional, São Paulo, v. 14, n. 2, p. 245260. 2010.

OLIVEIRA, Edileusa B. P. Percepção do Coordenador Pedagógico sobre Criatividade do Professor de Ensino Fundamental. 2009. 110 f. Dissertação (Mestrado em Educação) Universidade Católica de Brasília, Brasília, 2009.

OLIVEIRA, E. B. P.; ALENCAR, E. M. L. S. de. Importância da criatividade na escola e no trabalho docente segundo coordenadores pedagógicos. Estud. psicol. 2012, vol. 29, n. 4, p. 541-552.

OLIVEIRA, E. T. A.; WECHSLER, S. M. Variáveis que afetam a aprendizagem: percepção de alunos de licenciatura e professores. Psicol. esc. 2002, vol. 6, n. 2, p. 133-139.

OLIVEIRA, Eny da L. L. Criatividade e Escola uma articulação necessária: limites e possibilidades segundo gestores e orientadores educacionais. 2007. 118 f. Dissertação (Mestrado em Educação) - Universidade Católica de Brasília, Brasília, 2007.

OLIVEIRA, Lucilena M. C. de. Educação infantil e Criatividade: perspectiva de professoras. 2006. 242 f. Tese (Doutorado em Psicologia) - Centro de Ciências da Vida, PósGraduação em Psicologia, Pontifícia Universidade Católica de Campinas, Campinas, 2006.

OLIVEIRA, Zélia M. F. de; ALENCAR, E. M. L. S. de. Criatividade na formação e atuação do professor do curso de letras. Psicol. Esc. Educ., v.11, n.2, p. 223-237, 2007. 
OLIVEIRA, Zélia M. F. de. Criatividade: concepções e procedimentos pedagógicos na pósgraduação stricto sensu. 2012. 206 f. Tese (Doutorado em Educação) - Universidade Católica de Brasília, Brasília, 2012.

OTAVIANO, A. B. N. et al. Estímulo à criatividade por professores de Matemática e motivação do aluno. Psicol. Esc. 2012, v. 16, n. 1, p. 61-69.

PADGET, S. Creativity and Critical Thinking for Teachers in Training. London: Routledge, 2012.

PUCCIO, G. J et al. Creativity on Demand: Historical approaches and future trends. Artificial Intelligence for Engineering Design, Analysis and Manufacturing. v. 24, p. 153-159, 2010.

REILLY, R. C. et al. A synthesis of research concerning creative teachers in a Canadian context. Teaching and Teacher Education, n. 27, p. 533 -542, 2011.

RIBEIRO, R. A. Percepção de professores e estudantes de cursos de licenciatura quanto ao estímulo à criatividade. 2006. 76 f. Dissertação (Mestrado em Psicologia) - Universidade de Brasília, Brasília, 2006.

RIBEIRO, R. A.; FLEITH, D. de S. O estímulo à criatividade em cursos de licenciatura. Paidéia, Ribeirão Preto, v. 17, n. 38, p. 403-416, 2007.

RINKEVICH, J. L. Creative teaching: why it matters and where to begin. The Clearing House: A Journal of Educational Strategies, Issues and Ideas, v. 84, n. 5, p. 219-223, 2011.

RODRIGUES JUNIOR, J. O estímulo à criatividade e suas concepções por parte de professores das áreas de Saúde e Ciências Aplicadas. 2000. 87 f. Dissertação (Mestrado em Educação) - Universidade Católica de Brasília, Brasília, 2000.

ROSEMBERG, F. Do embate para o debate: educação e assistência no campo da educação infantil. In: MACHADO, M. L. A. (org.). Encontros e desencontros em educação infantil. São Paulo: Cortez, 2005.

ROSSATO, M. O movimento da subjetividade no processo de superação das dificuldades de aprendizagem escolar. 2009. 257 f. Tese (Doutorado em Educação) - Universidade de Brasília, Brasília, 2009.

SANTEIRO, T. V.; SANTEIRO, F. R. de M.; ANDRADE, I. R. de. Professor facilitador e inibidor da criatividade segundo universitários. Psicol. estud., v. 9, n. 1, p. 95-102, 2004.

SANTOS, Fábio A. A. dos. As crenças docentes sobre a criatividade e as práticas pedagógicas criativas: o caso do programa do ensino médio inovador no RN. 2013. $353 \mathrm{f}$. Tese (Doutorado em Educação) - Universidade Federal do Rio Grande do Norte, Natal, 2013.

SANTOS, Geandra C. S. Os Impactos na Subjetividade do Professor e a Configuração do Trabalho Pedagógico com Alunos que Têm Desenvolvimento Atípico. 2010. $221 \mathrm{f}$. Tese (Doutorado em Educação) - Faculdade de Educação, Universidade de Brasília, Brasília, 2010. 
SANTOS, Luciana L. D. dos. Concepções de criatividade na prática de professores de arte de anos finais do ensino fundamental, em escolas particulares de Brasília- DF. 2013. 109 f. Dissertação (Mestrado) - Universidade Católica de Brasília, Brasília, 2013.

SCHIRMER, A. C. F. Criatividade e educação infantil. 2001. 79 f. Tese (Doutorado em Educação) - Universidade Estadual de Campinas, Campinas, 2001.

SILVA, Christina P. da. Percepção de professores de Língua Portuguesa sobre práticas pedagógicas que promovem a criatividade. 2007. 79 f. Dissertação (Mestrado em Educação) - Universidade Católica de Brasília, Brasília, 2007.

SILVA, Onã J. da. A criatividade no ensino superior de enfermagem à luz dos componentes do processo ensino-aprendizagem: o professor, o aluno e o currículo. 2001. 104 f. Dissertação (Mestrado em educação) - Universidade Católica de Brasília, Brasília, 2001.

SILVA, Onã J.; ALENCAR, E. M. L. S. Criatividade no ensino de enfermagem - enfoque triádico: professor, aluno, currículo. Rev. bras. enferm. v. 56, n.6, p. 610-614, 2003.

SILVA, Patrícia A. N. Avaliação do Perfil da Criatividade do Professor no Ensino Médio. 2000. 74 f. Dissertação (Mestrado em Psicologia) - Instituto de Psicologia e Fonoaudiologia, Pontifícia Universidade Católica de Campinas, Campinas, 2000.

SILVA, Talita F. da; NAKANO, T. de C. Criatividade no contexto educacional: análise de publicações periódicas e trabalhos de pós-graduação na área da psicologia. Educ. Pesqui., v. 38, n. 3, p. 743-759, 2012.

SILVA, T. F. et al. Pesquisas sobre criatividade do professor em periódicos brasileiros: revisão. In: ENCONTRO NACIONAL DO CONSELHO BRASILEIRO PARA SUPERDOTAÇÃO, 5., 2012, Niterói. Anais... Niterói: ConBraSD, 2012. p. 1-21.

SOUZA, Dulce R. de. Atributos do professor que promove a criatividade em sala de aula e prática de avaliação no curso de pedagogia. 2005. 89 f. Dissertação (Mestrado em psicologia) - Universidade Católica de Brasília, Brasília.

SOUZA, Maria E. M. G. O curso de pedagogia e as condições para o desenvolvimento da criatividade. 2004. 128 f. Dissertação (Mestrado em psicologia) - Universidade Católica de Brasília, Brasília, 2004.

SOUZA, Maria E. M. G de ; ALENCAR, E. M. L. S de. O curso de Pedagogia e condições para o desenvolvimento da criatividade. Psicol. Esc. Educ., v. 10, n.1, p. 21-30, 2006.

TACCA, M. C. V. R. Além do Professor e de Aluno: a alteridade nos processos de aprendizagem e desenvolvimento. In: MITJÁNS MARTINEZ, A.; SIMÃO, M. L. (Org.). O Outro no Desenvolvimento Humano. São Paulo, SP: Pioneira Thomson Learning, p.101130. 2004.

TACCA, M. C. V. R. Relação Pedagógica e desenvolvimento da Subjetividade. In: GONZÁLEZ REY, F. L. (Org.). Subjetividade, Complexidade e Pesquisa em Psicologia. São Paulo, SP: Pioneira Thomson Learning, p. 215-240. 2005. 
TACCA, M. C. V. R. As Relações Sociais na Escola e Desenvolvimento da Subjetividade. In: SCOZ, B. et al. (Org.). Aprendizagem: tramas do conhecimento, do saber e da subjetividade. São Paulo, SP: Vozes, p.60-85. 2006.

TANGGAARD, L. Stories about Creative Teaching and Productive Learning. European Journal of Teacher Education. v. 34, n. 2, p. 219-232. 2011.

TARDIF, M.; LESSARD, C. O Trabalho Docente: elementos para uma teoria da docência como profissão de interações humanas. Trad. João B. Kreuch, 7 ed.. Petrópolis, RJ: Vozes, 2012 .

TARDIF, M. Saberes Docentes e formação Profissional. Petrópolis - RJ: Vozes, 2005.

TÁvorA, F. de O. F. A Expressão da Criatividade no Trabalho Pedagógico do Professor Alfabetizador. 2010. 112 f. Dissertação (Mestrado em educação) - Faculdade de Educação, Universidade de Brasília, Brasília, 2010.

TEIXEIRA, J. do N. Atributos e procedimentos do professor universitário facilitador da criatividade e o nível em que esta vem sendo estimulada em sala de aula. $2000.117 \mathrm{f}$. Dissertação (Mestrado em Educação) - Universidade Católica de Brasília, Brasília, 2000.

TORRANCE, E. P. Criatividade: medidas, testes e avaliações. Tradução Aydano Arruda. São Paulo: IBRASA, 1962.

TREVOR, D. Creative Teaching and Learning in Europe: Promoting a New Paradigm. Curriculum Journal., v. 17, n. 1, p.37-57, 2006.

TUNES, E.; TACCA, M. C. V. R.; Martínez, A. M. Uma Crítica às Teorias Clássicas da Aprendizagem e sua expressão no Campo Educativo. Revista Linhas Críticas, Brasília, v. 12, n. 22, p. 109-130. jan./jun. 2006.

USSENE, C. I. A formação do professor em exercício e o desenvolvimento criativo e reflexivo. 2006. 143 f. Dissertação (Mestrado em Educação) - Pontíficia Universidade Católica de São Paulo, São Paulo, 2006.

VIEIRA, F. B. de A.; MARTINS, L. de A. R. Formação e criatividade: elementos implicados na construção de uma escola inclusiva. Rev. bras. educ. espec., v. 19, n. 2, p. 225-242, 2013.

VILLAS BOAS, B. M. de F. A organização do trabalho pedagógico. In: VILLAS BOAS, B. M. de F. As práticas avaliativas e a organização do trabalho pedagógico. 1993. Tese (Doutorado em Educação) - Universidade Estadual de Campinas, Campinas, 1993.

VILLAS BOAS, B. M. de F. Tecendo articulações entre portfólio, avaliação e trabalho pedagógico. In: VILLAS BOAS, B. M. de F. Portfólio, avaliação e trabalho pedagógico. Campinas: Papirus, 2004. p. 177-191.

VIRGOLIM, A. M. R. Parada Obrigatória: a criatividade entrando em cena. In: VIRGOLIM, A. M. R. (Org.). Talento criativo: expressão em múltiplos contextos. Brasília, DF: Editora Universidade de Brasília, 2007. p. 19-28.

WESCHLER, S. M. Criatividade, descobrindo e encorajando: contribuições teóricas e práticas para as mais diversas áreas. Campinas: Psy, 1998. 
WECHSLER, S. M. Criatividade na cultura brasileira: uma década de estudos. Revista Portuguesa de Psicologia: teoria e investigação e prática, v. 6, n. 1, p. 215-227, 2001.

WECHSLER, S. M. Criatividade e desempenho escolar. Revista Linhas Críticas, Brasília, v. 8, n. 15, p. 179-188, 2002.

WECHSLER, S. M.; NAKANO, T. de C. Criatividade: encontrando soluções para os desafios educacionais. In: WECHSLER, S. M.; SOUZA, V. L. T. (Org.). Criatividade e aprendizagem: caminhos e descobertas em perspectiva internacional. São Paulo: Edições Loyola, 2011. p. 11-25.

WHITE, J. Areas of learning: creativity and performativity in Australian teacher education. Cambridge Journal of Education, v. 36, n. 3, p. 435-453, 2006.

YIN, R. K. O estudo de caso: planejamento e métodos. Porto Alegre: Bookman, 2010.

ZANELLA, A. V.; TITON, A. P. Análise da produção científica sobre criatividade em programas brasileiros de pós-graduação em Psicologia (1994 - 2001). Psicologia em Estudo, Maringá, v. 10, n. 2, p. 305-316, 2005. 


\begin{abstract}
APÊNDICE A
ROTEIRO DE OBSERVAÇÃO DO COTIDIANO EDUCATIVO

Principais aspectos que foram observados em relação aos professores participantes da pesquisa.
\end{abstract}

\title{
ROTEIRO DE OBSERVACÃO PARA A SALA DE AULA
}

\section{Espaço e recursos pedagógicos}

- Recursos pedagógicos utilizados (brinquedos, jogos, papéis, cartazes, etc.).

- Organização do espaço da sala de aula e a sua mobilidade (possibilidade de mudanças no mobiliário realizadas por professores e estudantes).

- Condições físicas e materiais e recursos disponíveis.

\section{Prática pedagógica e relação professor-alunos}

Fundamentados no Sistema Didático Integral de Mitjáns Martínez (2003)

- Tarefas realizadas em classe ou extra-classe.

- Seleção dos objetivos de aprendizagem e relação com os interesses apresentados pelos estudantes.

- Estratégias e métodos de ensino.

- Orientações e explicações em relação à rotina (cotidiano educativo), incluindo, o processo de avaliação e as tarefas para casa.

- Relações professor-alunos e o clima comunicativo-emocional entre eles.

\section{ROTEIRO PARA OBSERVACÃO NOS ESPACOS DE PARQUE, LANCHE E}

\section{RECREACÃO}

Relações entre os professores, direção e famílias

- Conversas informais entre os integrantes da dinâmica educativa e os assuntos mais presentes.

- Posicionamentos dos professores e intervenções nesses momentos.

- Ações e atividades desenvolvidas.

- Clima comunicativo-emocional entre os professores nos diversos espaços no trabalho pedagógico: coordenação pedagógica, reuniões coletivas, sala dos professores, dentre outros. 
- Clima comunicativo-emocional dos professores com a direção da instituição educativa: posicionamentos diante das propostas educativas, resolução de conflitos, recepção às novidades, etc.

- Clima comunicativo-emocional entre os professores e famílias: reuniões e diálogos com as famílias, posicionamentos diante das sugestões e queixas, posicionamentos em relação às novidades.

\section{ROTEIRO PARA OBSERVACC̃̃O NA COORDENACC̃̃O PEDAGÓGICA}

- Como ocorre o planejamento pedagógico: individual ou coletivo, materiais consultados.

- Participação dos professores.

- Troca de experiências.

- Leituras e reflexões realizadas (busca por informações, esclarecimentos de dúvidas).

- Seleção dos objetivos de aprendizagem: há consulta em documentos oficiais, se considera os interesses expressos pelos estudantes durante o período de aula.

- Produção das atividades: materiais consultados e utilizados para a elaboração e produção das atividades.

- Clima comunicativo-emocional entre os participantes do momento de coordenação pedagógica.

\section{ROTEIRO PARA OBSERVACÃO DE POSSÍVEIS INDICATIVOS DE}

\section{APRENDIZAGEM E DESENVOLVIMENTO DOS ESTUDANTES}

- Participação dos alunos nas atividades realizadas.

- Processos comunicativos realizados pelos estudantes: elaboração de perguntas, apresentação oral de dúvidas, de questionamentos, de opiniões.

- Mudanças de atitudes em relação ao estudo e acerca dos assuntos estudados.

- Implicação e envolvimento com as tarefas escolares.

- Autovaloração dos estudantes e possíveis mudanças nesta.

- Desenvolvimento e expressão da condição de sujeitos de aprendizagem. 


\section{APÊNDICE B ROTEIRO ENTREVISTA I}

\section{Trajetória de vida: pessoal e acadêmica}

- Informações gerais.

- Contexto sócio-cultural e econômico da infância, adolescência e idade adulta.

- Trajetória escolar.

- Professores que podem ter sido significativos no tempo de estudante e aqueles que podem ser referência em sua atuação.

- O melhor e o pior lugar.

- Principais períodos de mudanças em sua vida.

- Projetos pessoais realizados ou não realizados.

- Objetivos de sua vida: aspectos significativos.

- Situações ou momentos marcantes de conquistas e satisfação.

- Afetos e desafetos pessoais e acadêmicos.

- Se não fosse professor, seria...

- Informações a respeito de sua escolha profissional: motivação inicial.

- Formação acadêmica inicial: lembranças, influências na atuação, período.

- Formação continuada: participação em cursos e eventos, os espaços de coordenação pedagógica.

- Como percebe a relação entre sua formação, conhecimentos pedagógicos e sua atuação profissional.

- Projetos futuros. 


\section{APÊNDICE C ROTEIRO ENTREVISTA II}

\section{Trajetória profissional:}

- Início da trajetória profissional: expectativas iniciais.

- As primeiras experiências no magistério.

- Principais recursos pedagógicos utilizados e porquê.

- Medos e alegrias profissionais.

- Frustrações e satisfações com o trabalho pedagógico.

- Projetos realizados ou não realizados em relação à atuação profissional.

- O significado dos alunos em sua profissão e na sua vida.

- O significado da profissão em sua vida.

- Ingresso na Secretaria de Estado de Educação do DF: etapas de atuação, principais experiências.

- Ingresso na instituição educativa atual: tempo de atuação e experiências significativas.

- Relações com os alunos, professores, direção: como foram e como são.

- Principais projetos educativos realizados, de forma geral.

- Projetos educativos frustrados, que não corresponderam às expectativas iniciais, antes de sua realização.

- Projetos educativos que ainda gostaria de realizar.

- Como percebe o seu trabalho pedagógico: é criativo?

- Consegue identificar um momento marcante de sua criatividade no trabalho pedagógico.

- Se consegue identificar um momento que considera que tenha sido o início de sua criatividade no trabalho pedagógico.

- Implicações de sua criatividade na sua vida pessoal e profissional.

- Atestados médicos. 


\section{APÊNDICE D}

\section{TÚNEL DO TEMPO}

Em folhas separadas, foi solicitado que os professores registrassem três momentos de sua trajetória profissional que gostariam de reviver e outros três que, se pudessem, modificariam.

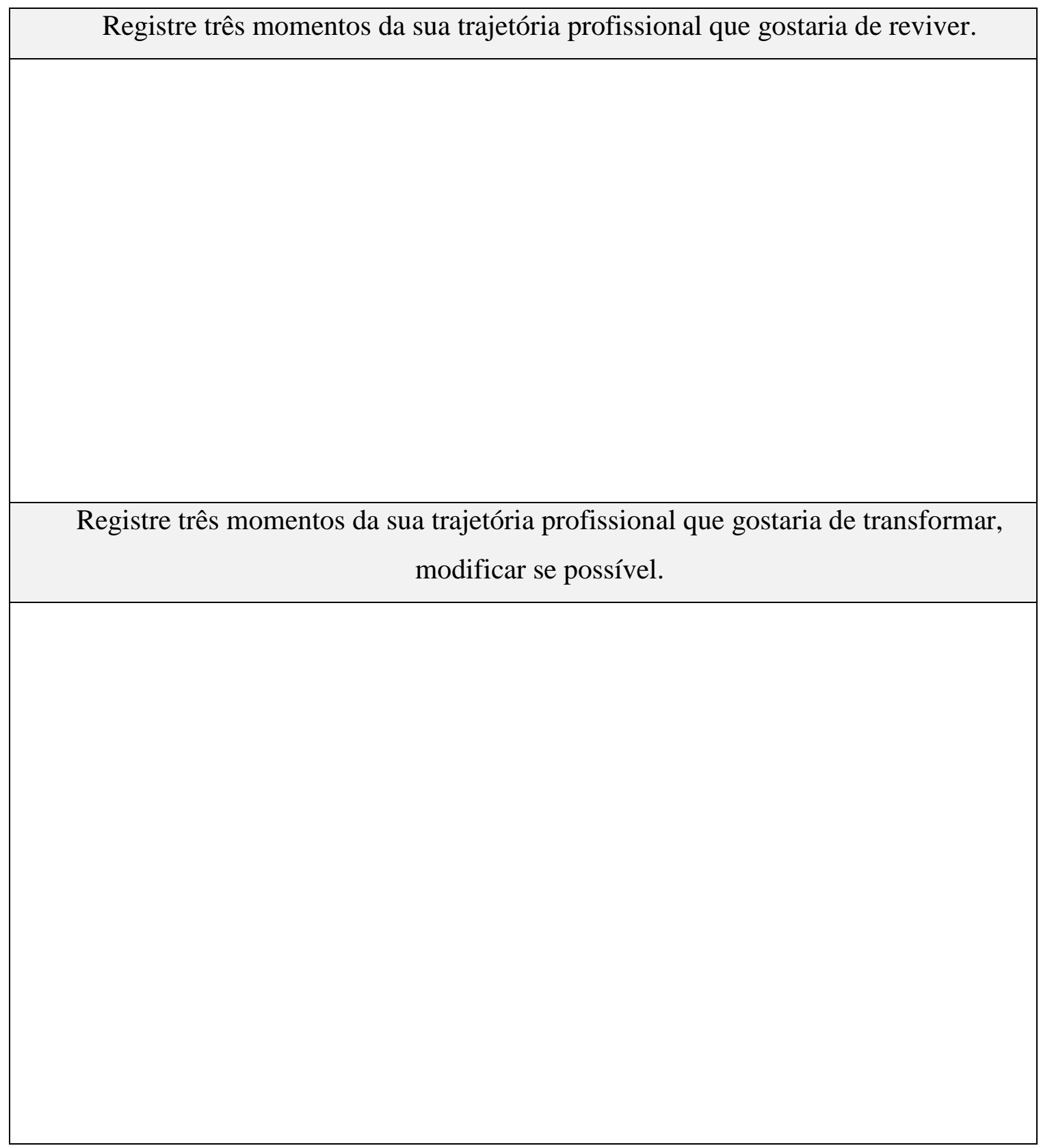




\section{APÊNDICE E \\ COMPLETAMENTO DE FRASES}

Prezado professor,

Complete as frases a seguir com a primeira ideia que surgir.

1. Eu gosto

2. O tempo mais feliz

3. Gostaria de saber

4. Lamento

5. Meu maior medo

6. Na escola

7. Não posso

8. Sofro

9. Fracassei

10. A leitura

11. Meu futuro

12. O casamento

13. Estou melhor

14. Algumas vezes

15. Este lugar

16. A preocupação principal

17. Desejo

18. Minha profissão

19. Secretamente eu

20. $\mathrm{Eu}$

21. Meu maior problema é

22. O trabalho

23. Amo

24. Minha principal ambição

25. Eu prefiro

26. Meu problema principal

27. Quero ser

28. Creio que as minhas melhores atitudes são

29. Esse ano letivo

30. A felicidade

31. Considero que posso

32. Esforço-me diariamente por

33. Sinto dificuldade

34. Meu maior desejo

35. Sempre quis

36. Gosto muito

37. Minhas aspirações são

38. Meus estudos

39. Minha vida futura

40. Farei o possível para alcançar

41. Frequentemente, reflito sobre

42. Proponho-me a

43. Meu maior tempo dedico a 
44. Sempre que posso

45. Luto

46. Frequentemente, sinto

47. As crianças

48. O passado

49. Esforço-me

50. As contradições

51. Minha opinião

52. Penso que os demais

53. O lar

54. Incomoda-me

55. Ao deitar-me

56. A gente

57. Uma mãe

58. Sinto

59. Os filhos

60. Quando eu era criança

61. Quando tenho dúvidas

62. No futuro

63. Necessito

64. Meu maior prazer

65. Odeio

66. Quando estou só

67. Meu maior temor

68. Se trabalho

69. Deprimo-me

70. O estudo

71. Meus amigos

72. Meu grupo

73. Considero que posso

74. A felicidade

75. A criatividade 


\section{APÊNDICE F \\ RESOLUÇÃO DE SITUAÇÕES DO COTIDIANO EDUCATIVO}

Foram apresentadas situações pedagógicas relacionadas com o cotidiano do professor, seja de educação infantil ou anos iniciais do ensino fundamental, de acordo com a atuação das participantes da pesquisa. Tais situações tiveram, como elemento comum, o processo de aprendizagem e questionamentos acerca do possível posicionamento do professor diante das demandas apresentadas por estudantes fictícios.

\section{Enunciado comum a todas as situações:}

Prezado professor (a),

O texto abaixo diz respeito a uma situação que pode ocorrer no cotidiano educativo. Gostaríamos que a analisasse e se colocasse diante das questões apresentadas a seguir.

Lembramos que não há respostas certas ou erradas! Sinta-se à vontade para se posicionar e opinar!

\section{Para professora que atuava na Educação Infantil}

Em uma turma de crianças de cinco anos há um estudante, João, que constantemente fala a respeito dos desenhos infantis que assiste no período contrário a sua aula. Durante os diálogos espontâneos da professora com a turma, na contação de histórias e na explicação das atividades o estudante interrompe a fala da professora e de outras crianças para citar exemplos de fatos que ocorreram nos desenhos animados.

A) O que você faria diante de uma situação como a apresentada acima para favorecer os processos de aprendizagem de (nome fictício. Na educação infantil: dos alunos)? Explique o mais detalhadamente possível as suas escolhas e os motivos que conduziram a elas.

B) Como você poderia utilizar esta situação em seu trabalho pedagógico?

C) O que você não faria em hipótese alguma? Explique detalhadamente os motivos. 


\section{Para professora que atuava no Ensino fundamental ( $1^{\circ}$ ano $)$ - Situação A}

Em uma turma de alfabetização, a professora iniciou a identificação da letra A. Para isso, avisou a todas as crianças que chegaria a sala um novo integrante, uma mascote: a abelha (de pelúcia). A mascote poderia passar um dia da semana na casa de cada aluno da turma. Eles ficaram muito entusiasmados e comentaram que poderiam fazer uma festa para recebê-la, que iriam levá-la para dormir em suas camas, que iriam passear com ela, dentre outras possibilidades.

\section{Para professora que atuava no Ensino fundamental ( $5^{\circ}$ ano $)$ - Situação B}

Em uma turma de quinto ano, entrou no início do mês de abril, uma aluna nova chamada Maria. Ela era negra e vinha de uma cidade do Nordeste brasileiro. Tinha forte "sotaque" regional em sua fala e modos distintos de se relacionar com os colegas (brincadeiras diferentes com muitos toques e abraços). Os estudantes dessa turma estranharam, poucos se aproximavam dela para as atividades realizadas e não aceitavam as brincadeiras que ela fazia. Nesse primeiro mês, Maria foi excluída pelos alunos e nas primeiras atividades educativas teve baixo desempenho. 


\section{APÊNDICE G DUAS GRANDES PREMIAÇÕES}

Prezada professora,

O questionário abaixo envolve a sua indicação acerca de duas experiências pedagógicas que ocorreram ao longo de sua carreira e que você julga serem merecedoras de premiação. Tais experiências podem se referir a atividades ou projetos realizados. Para tanto, será preciso que responda às questões abaixo o mais detalhadamente possível.

Para o prêmio de $1^{\circ}$ lugar:

1. Relate uma experiência pedagógica que merece um prêmio de destaque em sua carreira profissional. (em torno de 10-15 linhas)

2.Indique os objetivos de aprendizagem propostos e sua origem. (7 linhas)

3. Quais foram os integrantes da experiência pedagógica? (7 linhas)

4. Quais foram as principais atividades desenvolvidas?

5.Por que indicou essa experiência? Em que ela foi mais significativa para você?

6. Você a realiza atualmente? Por quê?

Para o prêmio de $2^{\circ}$ lugar:

1. Relate uma experiência pedagógica que merece um prêmio em sua carreira profissional. (em torno de 10-15 linhas)

2. Indique os objetivos de aprendizagem propostos e sua origem. (7 linhas)

3. Quais foram os integrantes da experiência pedagógica? Quais eram as pessoas que participaram? (7 linhas)

4. Quais foram as principais atividades desenvolvidas? (10 linhas)

5.Por que indicou essa experiência? Em que ela foi mais significativa para você? (10 linhas)

6. Você a realiza atualmente? Por quê? (7 linhas) 